\title{
DIVERSIDADE E ESTRUTURA DE COMUNIDADES DE BACTERIA EM SOLOS TRATADOS COM BIOSSÓLIDOS
}

\author{
Ângela Garcia de Souza \\ Química
}

Orientador: Prof. Dr. Marcio Rodrigues Lambais

Tese apresentada à Escola Superior de Agricultura "Luiz de Queiroz", Universidade de São Paulo, para obtenção do título de Doutor em Agronomia, Área de Concentação: Microbiologia Agrícola

PIRACICABA

Estado de São Paulo

Janeiro - 2002 


\section{ERRATA:}

Item Resumo, pg. xxi, §único 2alinha, onde se lê:..., ao longo do tempo $(0 ; 1 ; 2 ; 4$ e 8 semanas)..., leia-se:...amostrados em 1, 2, 4 e 8 semanas...

Item Resumo, pg. xxi, §único 9alinha, onde se lê:..., Eutroférrico tipico), cultivado com milho, ..., leia-se:...Eutroférrico tipico), incubados por 60 dias e posteriormente cultivados com milho. As avaliaçōes foram feitas 30 e 60 dias após o plantio do milho.

Item Resumo, pg. xxi, §único 21alinha, onde se lê:...doses e tipo de biossólido e tipo de solos utilizados..., lei-se:.. doses e tipos de biossólidos e solos utilizados....

Item Resumo, pg. xxi, §único, 27alinha, onde se lê:...valores de $\mathrm{S}$ (riqueza de espécies). H (diversidade) foi quase constante e $\mathrm{D}$ (dominância) e $\mathrm{E}$ (eqüitabilidade) são dependentes das doses de biossólidos aplicadas., leia-se:...valores de $S$ (número de amplicons). Os valores obtidos para o indice de Shannon-Weaver $(H)$ mostraram baixa variabilidade e os resultados de dominância (D) e eqüitabilidade (E) foram dependentes das doses de biossólidos aplicadas.

Ítem Summary, pg. xxii e xxiii, substituir todo conteúdo

The use of biosolids in agricultural soils has been extensively recommended as a source of plant nutrients and a soil conditioner. Even though biosolids have several beneficial effects on plant growth, little is known on their impact upon soil microorganisms. High concentrations of metals and antimicrobial compounds frequently found in biosolids may affect the soil microbial community structure and physiology. Since soil quality may be related to genetic and/or functional diversity, the effects of biosolids on soil microbial communities must be characterized. The aim of this work was to assess changes in Bacteria genetic diversity and community structure upon soil amendment with biosolids from two Sewage Treatment Plants (STP), using denaturing gradient gel electrophoresis (DGGE) of a 165 rDNA fragment. In the first experiment, a Typic Rhodudalf was amended with the equivalent to $6,12,24,48 \mathrm{Mg} \mathrm{ha}^{-1}$ of biosolids from STP-Franca. Soil without biosolids was used as a control. Evaluations of Bacteria community structure and diversity indexes were performed at 1, 2, 4 and 8 weeks after biosolid amendments. In the second experiment, biosolids from STP-Barueri and STP-Franca, characterized by high and low concentrations of heavy metals, respectively, were added to clay (Typic Rhodudalf) and sandy soil (Typic Quartzipsamment) at concentrations equivalent to $6,24,96 \mathrm{Mg} \mathrm{ha}^{-1}$ of biosolids from STP-Franca or 31, 62, 124 $\mathrm{Mg} \mathrm{ha} \mathrm{h}^{-1}$ of biosolids from STP-Barueri, based on nitrogen availability. As controls, soils without biosolids were used. Soils were incubated for 60 days before planting maize, at greenhouse conditions. Evaluations of Bacteria community structure and diversity indexes were performed 30 and 60 days after planting. The results of the first experiment showed that the amendment of STP-Franca modified the community structure of Bacteria over the time. Higher values of amplicon richness and Shannon-Weaver diversity index at the beginning of the experiment and higher dominance eight weeks after biosolids amendment indicate a transient effect of the biosolids on microbial populations. In the second experiment, it was observed that Bacteria community structure in cultivated soils depends on the origin and doses of biosolids, soil type and cultivation time. Bacteria community structure in soils amended with biosolids from STP-Franca were more similar to the controls without biosolids than to soils with biosolids from STP-Barueri, especially in the sandy soil. Amplicon richness and the Shannon-Weaver diversity index showed less variability in soil samples taken 60 days after planting. 


\section{ERRATA}

Item 1, pg. $3,2^{\circ} \S 2^{a}$ linha, onde se lê:...genética de Bacteria..., leia-se:...genética de Bacteria...

Item 2.1, pg.4, $2^{\mathrm{a}} \S 1^{\mathrm{a} l i n h a,}$ onde se lê: As ETEs, recebem,..., leia-se: As ETEs recebem...

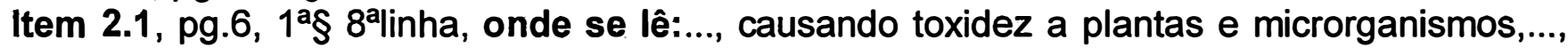
leia-se:... causando toxidez às plantas e microrganismos, ...

Item 2.2, pg. 8 - $2^{\mathrm{a}} \S 4^{\mathrm{a}}$ linha, onde se lề: $\ldots$ seu estágio de desenvolvimento, leia-se: seu estádio de desenvolvimento,....

Item 2.2, pg. 8, $3^{\text {a }} 3^{\circ}$ linha, onde se lê:...(McGrathl., 1994)...., leia-se: ...(McGrath, 1994).... Item 2.2, pg. 9, Quadro 1, onde se lê:...cromo...., leia-se:...crômio....

Item 2.2, pg. $10,2^{\mathrm{a}} \S 1^{\circ}$ linha, onde se lê:...diferentes pHs..., leia-se:...diferentes valores de $\mathrm{pH} \ldots$.

Item 2.2, pg. $10,2^{\mathrm{a}} \S 5^{\circ}$ linha, onde se lê:...solos exercem mais..., leia-se: ...solos exerceram mais...

Item 2.2, pg. $10,2^{\mathrm{a}} \S 6^{\circ}$ linha, onde se lê:...alta toxocidade...., leia-se: ...alta toxicidade...

Item 2.2, pg. 11, $1^{\text {a }} \S 4^{\circ}$ linha, onde se lê:...por Mielthling et al. (2000), os quais detectaram..., leia-se:...por Mielthling et al. (2000). Estes autores detectaram....

Item 2.2, pg. 11, $1^{\text {a }} \S 8^{\circ}$ linha, onde se lê:...Às comunidade..., leia-se:...As comunidades....

Item 2.2, pg. 12, 1å $6^{\circ}$ linha, onde se lê:...e micorriza...., leia-se: ...e de fungos micorrizicos...

Item 2.2, pg. $12,2^{\mathrm{a}} \S 2^{\circ}$ linha, onde se lê:...na sobrevivência...., leia-se:...no tamanho e atividade...

Item 2.2, pg. 13, $1^{\mathrm{a}} \S 2^{\circ}$ linha, onde se lê:...A análise por microscopia eletrônica de transmissão mostrou que um novo mecanismo de seqüestro intracelular do $\mathrm{Pb}$ é usado...., leia-se: ...A análise por microscopia eletrônica de transmissão possibilitou a identificação de...

Item 2.2, pg. 13, $3^{\text {a }} 3^{\circ}$ linha, onde se lê:...Kuperman \& Carreiro (1997),..., leiase:...Kuperman \& Carreiro (1997)....

Item 2.3, pg. 15, $1^{\circ} \S 3^{a}$ linha, onde se lê:...bacterianos pode participar dos diversos processos biogeoquímicos (Alexander, 1977). Em solos colonizados por plantas, podemos encontrar,..., leia-se:... bacterianos podem participar dos diversos processos biogeoquímicos (Alexander, 1977). Em solos colonizados por plantas, são encontradas,...

Item 2.3, pg. 16, $2^{\mathrm{a}} \S 4^{\circ}$ linha, onde se lê::...Em geral, esses métodos..., leia-se:....Em geral, estes métodos...

Item 2.4, pg. $20,2^{\text {a }} 1^{\circ}$ linha, onde se lê:...exercida...., leia-se: ...causada...

Item 2.4, pg. 21, $1^{\text {å }} 5^{\circ}$ linha, onde se lê:...amplicons...., leia-se: ....amplicons do rDNA $16 \mathrm{~S} . .$.

Item 2.5 , pg. 23 - $2^{\text {a }} \S 1^{\circ}$ linha, onde se lê:...microrganismos são a primeira etapa..., leia-se: .... microrganismos podem ser as primeiras etapas...

Item 2.5, pg. 25, $3^{\text {a }} 1^{\circ}$ linha, onde se lê:...Bacteria..., leia-se: ...Bacteria,... 


\section{ERRATA}

Item 3.1.2, pg. $29,2^{\text {a }} \S 10^{\circ}$ linha, onde se lê:...À extração com resina de troca..., leia-se:...A extração com resina de troca iônica e/ou catiônica...

Item 3.2.4, pg. $32,2^{\mathrm{a}} \S$, onde se lê:...A calagem dos solos foi realizada com calcário dolomítico (PRNT 130\%) para elevar a saturação em bases para $70 \%$. Nos tratamentos com adubação completa foram utilizados: $100 \mathrm{mg} \mathrm{K} \mathrm{kg}^{-1}$ solo (como nitrato de potássio), $100 \mathrm{mg}$ $\mathrm{P} \mathrm{kg}^{-1}$ solo (como super fosfato simples) e $100 \mathrm{mg} \mathrm{N} \mathrm{kg}^{-1}$ solo (como sulfato de amônî)...., eliminar todo parágrafo.

Item 3.3, pg. 33, $3^{\text {å }} 7^{\circ}$ linha, onde se lê:....por $130 \mathrm{~s} . . .$, leia-se: ....por $30 \mathrm{~s} . .$.

Item 3.4, pg. $34,3^{\text {a }} 5^{\circ}$ linha, onde se lê:....; 1,5 $U$ de Taq DNA polimerase..., leia-se: ....; $0,4 \cup$ de Taq DNA polimerase...

Item 3.5, pg. $35,2^{\text {a }} 6^{\circ}$ linha, onde sé lê:...uma solução $100 \%$ de capacidade desnaturante, contendo $7 \mathrm{M}$ uréia e $40 \%$ formamida..., leia-se:...uma solução contendo, $7 \mathrm{M}$ uréia e $40 \%$ formamida, considerada como $100 \%$ de capacidade desnaturante

Item $3.8, \mathrm{pg} .38,2^{\mathrm{a}} \S 2^{\circ}$ linha, onde se lê:...R, riqueza de espécies (número de ampliçons em cada tratamento);...; $\mathrm{S}$, índice de dominância de Simpson;..., leia-se:...S, número de amplicons em cada tratamento;...; $D$, índice de dominância de Simpson.

Item 3.8, pg. $38,3^{a} \S 1^{\circ}$ linha, onde se lê: $O$ índice de dominância de Simpson (S) foi calculado segundo a equação: $S=\Sigma p_{i}^{2}$, onde: $S=$ indice de dominância de Simpson....., leiase: $O$ índice de dominância de Simpson (D) foi calculado segundo a equação: $D=\Sigma p_{i}^{2}$, onde: $D=$ indice de dominância de Simpson...

Item 3.8, pg. $39,1^{\text {å }} 1^{\circ}$ linha, onde se lê: onde:...R = número de amplicons...., leia-se: $S=$ número de amplicons....

Item 3.9, pg. $39,2^{\mathrm{a}} \S 9^{\circ}$ linha, onde se lê:...clonado previa.ente...., leia-se:...clonado previamente...

Item $3.9, \mathrm{pg} .39,3^{\text {a }} \S 3^{\circ}$ linha, onde se lê:...envolve das seguintes..., leia-se:...envolve as seguintes...

Item 3.9, pg. 40, $1^{\text {å }} 3^{\circ}$ linha, onde se lê:...e os iniciadores F e UN518r..., leia-se:...e os iniciadores F ("Foward" universal) e UN518r 


\section{ERRATA}

Item 4.1.5, pg. $58,3^{\circ} \S$, $3^{\circ}$ linha, onde se lê:...os valores de $S$ obtidos para os solos que receberam quantidades de biossólido equivalentes a 12,24 e $48 \mathrm{Mg}^{\text {hal }}{ }^{-1}$ (7) são semelhantes ao controle (6). Somente quando quantidades de biossólido equivalente a $6 \mathrm{Mg}$ $h^{-1}$, o valor encontrado foi mais baixo (4), para o mesmo tempo de incubação..., leiase:... os valores de $S$ aumentaram conforme o aumento das doses de biossólido. Somente quando o solo recebeu quantidade equivalente a $6 \mathrm{Mg} \mathrm{ha}^{-1}$, o valor de $\mathrm{S}$ foi inferior ao controle. Para os solos que receberam quantidades de biossólido equivalentes a 24 e $48 \mathrm{Mg}$ ha $^{-1}$ não houve variação do $S(11)$.

Item 4.1.5, pg. $58,3^{\circ} \S, 8^{\circ}$ linha, onde se lê:..., os valores de $S$ duplicaram, leia-se:... os valores de $S$ aumentaram,...

Item 4.1.5, pg. 59, Figura 6, alteração da Figura

T1 de incubação: Valores de S para: ...dose 3 onde se lê:...7, leia-se: 8

...dose 4 onde se lê:...7, leia-se: 11

...dose 5 onde se lê:...7, leia-se: 11

T1 de incubação: Valores de H para: ...dose 3 onde se lê:...2,5, leia-se: 2,7

...dose 4 onde se lê:...2,7, leia-se: 1,9

...dose 5 onde se lê:...2,2, leia-se: 2,6

Item 4.1.5, pg. 59, Figura 6, Legenda, onde se lê:...A, Riqueza de espécies (S); Índice de Shannon-Weaver $(H), \ldots$. , leia-se:...A, número de amplicons $(S)$; $B$, Índice de ShannonWeaver $(\mathrm{H}), \ldots$

Item 4.1.5, pg. 60, Figura 7, alteração da Figura

T1 de incubação: Valores de D para: $\quad$...dose 3 onde se lê:...0,21, leia-se: 0,17

...dose 4 onde se lê:...0,17, leia-se: 0,05

...dose 5 onde se lê:...0,25, leia-se: 0,22

T1 de incubação: Valores de E para: ...dose 3 onde se lê:...0,90, leia-se: 0,92

...dose 4 onde se lê:...0,94, leia-se: 0,55

...dose 5 onde se lê:...0,80 leia-se: 0,76

Item 4.1.5, pg. $61,1^{\circ} \S, 3^{\circ}$ linha, onde se lê:... Na amostra tratada com quantidade de biossólido equivalente a $24 \mathrm{Mg} \mathrm{ha}^{-1}$ não ocorreu variação significativa até quatro semanas de incubação $(2,6)$, decrescendo em 8 semanas $(1,9)$. Nas amostras tratadas com quantidades equivalentes a 6, 12 e $48 \mathrm{Mg}_{\text {ha }}{ }^{-1}$ o valor de $\mathrm{H}$ cresceu $(1,6-3,0)$ com o tempo de incubação, decrescendo posteriormente até igualar-se ao controle, após 8 semanas. leia-se:....Na amostra tratada com quantidade de biossólido equivalente a $24 \mathrm{Mg} \mathrm{ha}^{-1}$ não ocorreu variação entre a primeira e última época de coleta, após 8 semanas de incubação $(1,9)$, ocorrendo aumento no decorrer deste período $(2,6-2,5)$. Nas amostras tratadas com quantidades equivalentes a $6 \mathrm{Mg} \mathrm{ha}^{-1}$ o valor de $\mathrm{H}$ cresceu $(1,6-2,9)$ com o tempo de incubação. $\mathrm{O}$ maior valor de $H$, após 1 semana de incubação foi obtido para a amostra de solo tratada com quantidade equivalente a $12 \mathrm{Mg} \mathrm{ha}^{-1}$. Em todos os tratamentos houve um decréscimo nos valores de $\mathrm{H}$, após 8 semanas, igualando a dose 1 (controle), exceto a dose mais alta cujo valor não foi calculado. 


\section{ERRATA}

Item 4.1.4, pg. 49, $1^{\text {å }} 4^{\circ}$ linha, onde se lê:...A análise do gel de DGGE..., leia-se:... A análise do gel de poliacrilamida após eletroforese com gradiente desnaturante...

Item 4.1.4, pg. 54, $2^{\mathrm{a}} \S 7^{\circ}$ linha, onde se lê:..Este grupo caracteriza as amostras de solo com maior distúrbio com alterações adversas resultantes da adição e mineralização da matéria orgânica... leia-se:... Este grupo apresentou menor similaridade em relação ao controle, provavelmente, devido ao maior distúrbio observado resultantes da adição e mineralização da matéria orgânica...

Item 4.1.4, pg. 55, Figura 5,...

Grupo 1

onde se lê:...D1T2..., leia-se:...D2T2

onde se lê:...D2T2..., leia-se:...D3T2

onde se lê:...D3T2..., leia-se:...D4T2

onde se lê:...D1T3..., leia-se:...D2T3

onde se lê:...D0T3..., leia-se:...D1T3

Grupo II

onde se lê:...D4T2..., leia-se:...D5T2

onde se lê:...D0T2..., leia-se:...D1T2

onde se lê:...D4T1..., leia-se:...D5T1

onde se lê:...D3T1..., leia-se:...D4T1

onde se lê:...D3T3..., leia-se:...D4T3
Grupo III

onde se lê:...D2T3..., leia-se:...D3T3

onde se lê:...D2T4..., leia-se:...D3T4

onde se lê:...D0T4..., leia-se:...D1T4

onde se lê:...D1T4..., leia-se:...D2T4

onde se lê:...D3T4..., leia-se:...D4T4

onde se lê:...D1T1..., leia-se:...D2T1

onde se lê:...D0T1 ..., leia-se:...D1T1

onde se lê:...D2T1..., leia-se:...D3T1

Item 4.1.4, pg. 55, Figura 5, legenda, onde se lê:...Dendograma..., leia-se: Dendrograma...

Item 4.1.4, pg. 56, $1^{\text {as }} 1^{\circ}$ linha, onde se lê:..Os coeficientes de similaridade das comunidades de Bacteria..., leia-se:...A estrutura da comunidade de Bacteria, avaliada comparando-se os coeficientes de similaridade das comunidades encontradas...

Item 4.1.4, pg. $56,2^{\mathrm{a}} \S 2^{\circ}$ linha, onde se lê:...os valores de C-biomassa foram significativamente diferentes..., leia-se:... os valores de C-biomassa foram significativamente maiores que o controle sem biossólido...

Item 4.1.4, pg. $56,2^{\mathrm{a}} \S 9^{\circ}$ linha, onde se lê:...corroborando com os dados..., leia-se:...os dados obtidos neste experimento demonstraram que após 2 semanas de incubação o número de amplicons foi maior que em outros períodos.....

Item 4.1.4, pg. 57, $2^{\mathrm{a}} \S 9^{\circ}$ linha, onde se lê:...Isso porque a morte das células aumenta a disponibilidade de substrato, modificando o ambiente e afetando os complexos com a matéria orgânica, tornando este menos disponivel...., leia-se:...A presença de material orgânico proveniente da morte de células microbianas, altera a disponibilidade de substratos disponíveis modificando os complexos presentes. 


\section{ERRATA}

Item 4.1.5, pg. $61,2^{\circ} \S, 4^{\circ}$ linha, onde se lê::...A aplicação de biossólido em quantidade equivalente a 6, 12 e $24 \mathrm{Mg} \mathrm{ha}^{-1}$, em geral, aumentaram o valor de $\mathrm{D}$ ao longo do tempo de incubação $(0,17-0,25)$. Após 8 semanas, não há diferenças entre os valores de $D$ em ralação à dose de biossólido aplicada. Somente na amostra tratada com $48 \mathrm{Mg} \mathrm{ha}^{-1}$ ocorreu um decréscimo no valor de $D$ entre a primeira e segunda semana de incubação, mantendo-se posteriormente um valor constante. leia-se:...A aplicação de quantidade de biossólido equivalente a $12 \mathrm{Mg} \mathrm{ha}^{-1}$, em geral aumentou o valor de $\mathrm{D}$ ao longo do tempo de incubação $(0,17-0,25)$. A aplicação de biossólido em quantidade equivalente a $24 \mathrm{Mg} \mathrm{ha}^{-1}$ apresentou um aumento significativo em 1 semana de incubação, mantendo-se pouco alterado até 8 semanas. A aplicação de biossólido em quantidade equivalente a $12 \mathrm{Mg} \mathrm{ha}^{-1}$ decresceu significativamente, após 1 semana de incubação. Em geral, após 8 semanas de incubação, todos os valores ficaram próximos, inclusive o controle.

Item 4.1.5, pg. $61,3^{\circ} \S, 2^{\circ}$ linha, onde se lê:....Com 1 semana de incubação do solobiossólido o valor de $E$ foi crescente até a aplicação da dose equivalente a $24 \mathrm{Mg} \mathrm{ha}^{-1}$ de biossólido. Com a aplicação de $48 \mathrm{Mg} \mathrm{ha}^{-1}$ o valor de $\mathrm{E}$ foi menor que o controle. Após 2 e 4 semanas de incubação, os valores de $E$ foram crescentes de acordo com o aumento da dose de biossólido. Após 8 semanas de incubação, em geral, não há variação nos valores de $D$ com o aumento da dose de biossólido. leia-se:...Com 1 semana de incubação do solobiossólido o valor de $E$ foi maior que o controle, somente na amostra de solo tratada com 12 $\mathrm{Mg} \mathrm{ha}{ }^{-1}$, sendo que a dose 4 foi significativamente diferente de todas as outras doses aumentando conforme o tempo de incubação. Em geral, após 8 semanas de incubação, todos os valores ficaram próximos, inclusive o controle.

Item 4.1.5, pg. $62,1^{\circ} \S, 3^{\circ}$ linha, onde se lê:...solos tratados com biossólidos em relação controle..., leia-se:...solos tratados com biossólidos em relação ao controle...

Item 4.1.5, pg. $62,1^{\circ} \S, 7^{\circ}$ linha, onde se lê:...controle sem biossólido. leia-se:...controle sem biossólido em relação a $S$.

Item 4.1.5, pg. $62,1^{\circ} \S 10^{\mathrm{a}}$ linha, onde se lê:...A aplicação de biossólido ao solo alterou os indices de diversidade em relação ao controle de cada época de amostragem, sugerindo que ocorreram alterações na estrutura da comunidade. 0 aumento da eqüitabilidade após 8 semanas de incubação sugere que a aplicação do biossólido modificou a estrutura da comunidade de Bacteria como resposta ao distúrbio imposto, porém, este não foi persistente, demonstrando a rápida recuperação do solo ou resiliência do sistema., leia-se:...A aplicação de biossólido ao solo modificou a composição de espécies entra os tratamentos em cada época de amostragem. Maiores taxas de matéria orgânica, estimulam o crescimento microbiano, resultando em alterações na estrutura da comunidade, conforme as condições mais ou menos favoráveis. $O$ aumento da eqüitabilidade após 8 semanas de incubação sugere que a estrutura da comunidade de Bacteria difere entre os tratamentos como resposta ao distúrbio imposto. Isso foi verificado pelo decréscimo acentuado no número de amplicons, demonstrando a resiliência do sistema.

Item 4.1.5, pg. $63,2^{\circ} \S 5^{a}$ linha, , onde se lê:...Da mesma forma, Griffiths et al. (2000) encontraram menor biodiversidade e conseqüente redução nas taxas de nitrificação com decréscimos nos processos de decomposição..., leia-se: Da mesma forma, Griffiths et al. (2000) encontraram valores reduzidos nos processos de decomposição, quando as taxas de nitrificação e a biodiversidade foram reduzidas. Isso sugere que grupos microbianos específicos, relacionados com o processo de nitrificação, tornaram-se dominantes.... 


\section{ERRATA}

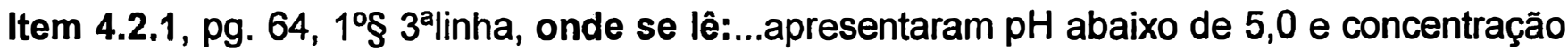
de..., leia-se:...apresentaram valores de $\mathrm{pH}$ de 5,4 e 3,5, respectivamente, para solo argiloso e arenoso.

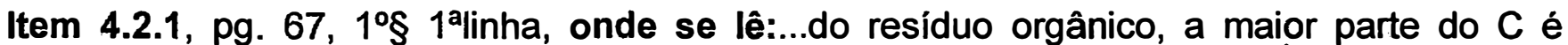
mineralizado a $\mathrm{CO}_{2}, \mathrm{~N}, \mathrm{P}$ e $\mathrm{S}$ além de outros componentes menores.,...leia-se:..do resíduo orgânico, a maior parte da matéria orgânica presente no biossólido foi mineralizada à $\mathrm{CO}_{2}$, $\mathrm{N}, \mathrm{P}$ e $\mathrm{S}$, além de outros componentes menores

Item 4.2.1, pg. $68,1^{\circ} \S 1^{a}$ linha, onde se lê:...O material orgânico e inorgânico resultante da decomposição da matéria orgânica, se transforma em formas inorgânicas disponiveis para as plantas.,..., leia-se:..O material orgânico, resultante da decomposição da matéria orgânica, se transforma em formas inorgânicas disponiveis para as plantas.

Item 4.2.2, pg. $68,2^{\circ} \S 9^{a}$ linha, onde se lê:...Os resultados indicam que à metodologia utilizada....., leia-se:...Os resultados indicam que a metodologia utilizada.... 


\section{ERRATA}

Item 4.2.4, pg. 79, 1§ $1^{\text {alinha, }}$ onde se lê:...Por outro lado, Sitaula et al. (1999) determinaram a distribuições da atividade de metais..., leia-se:...Sitaula et al. (1999) determinaram a distribuição das atividades de metais...,

Item 4.2.4, pg. 85 - Figuras:

onde se lê::...ARGF0..., leia-se:...ARGF1

onde se lê:...ARGF1..., leia-se:...ARGF2

onde se lê:...ARGF2..., leia-se:...ARGF3

onde se lê:...ARGF3..., leia-se:...ARGF4

onde se lê:...AREF0..., leia-se:...AREF1

onde se lê:...AREF1..., leia-se:...AREF2

e onde se lê:...ARGB0..., leia-se:...ARGB1

e onde se lê:...ARGB1..., leia-se:...ARGB2

e onde se lê:...ARGB2..., leia-se:...ARGB3

e onde se lê:...ARGB3..., leia-se:...ARGB4

e onde se lê:...AREB0..., leia-se:...AREB1

e onde se lê:...AREB1..., leia-se:...AREB2

e onde se lê:...AREB2..., leia-se:...AREB3

onde se lê:...AREF2..., leia-se:...AREF3

onde se lê:...AREF3..., leia-se:...AREF4

e onde se lê:...AREB3..., leia-se:...AREB4

Item 4.2.4, pg. 85, Legenda, onde se lê:...Figura 14 - Dendograma...., leia-se: Figura 14 Dendrograma....

Item 4.2.4, pg. 86, $2^{\circ} \S 1^{1}$ linha, onde se lê: Kowalchuk et al. (1977), observaram as diferenças..., leia-se: Kowalchuk et al. (1977) observaram as diferenças....

Item 4.2.4, pg. 97 - Figuras:

onde se lê:...ARGF0..., leia-se:...ARGF1 e onde se lê:...ARGB0..., leia-se:...ARGB1

onde se lê:...ARGF1..., leia-se:...ARGF2 e onde se lê:...ARGB1..., leia-se:...ARGB2

onde se lê:...ARGF2..., leia-se:...ARGF3 e onde se lê:...ARGB2..., leia-se:...ARGB3

onde se lê:...ARGF3..., leia-se:...ARGF4 e onde se lê:...ARGB3..., leia-se:...ARGB4

onde se lê::..AREF0..., leia-se:...AREF1 e onde se lê:...AREB0..., leia-se:...AREB1

onde se lê:...AREF1..., leia-se:...AREF2 e onde se lê:...AREB1..., leia-se:...AREB2

onde se lê:...AREF2..., leia-se:...AREF3 e onde se lê:...AREB2 ..., leia-se:...AREB3

onde se lê:...AREF3..., leia-se:...AREF4 e onde se lê:...AREB3..., leia-se:...AREB4

Item 4.2.4, Legenda, onde se lê:...Figura 19 - Dendograma...., leia-se: Figura 19 Dendrograma....

Item 4.2.4, pg. $99,1^{\circ} \S 7^{\text {alinha, }}$ onde se lê:...da diversidade de Bacteri,.., leia-se:...da diversidade de Bacteria,....

Item 4.2.4, pgs. 101; 110; Figura 20 e Figura 24, respectivamente, onde se lê:...Riqueza de espécies (S) em solo argiloso (ARG) ou arenoso (ARE), em função da dose de biossólido adicionada, avaliada 30 (1) e 60 (2) dias após o plantio de milho. Os valores de $S$ foram calculados a partir dos dados de abundância relativa dos amplicons....A, solos tratados com biossólido da ETE-Franca:...; ETE-Barueri:... A e B, 30 dias após o plantio de milho; C e D, 60 dias após o plantio de milho., leia-se:...: Figura 20 e Figura 24, respectivamente - Índices de diversidade dos amplicons da região V3 do rDNA 16S. Número de amplicons em cada tratamento (S) em solo argiloso ou arenoso, em função da dose de biossólido adicionada, avaliada $30\left(1^{\mathrm{a}}\right)$ e $60\left(2^{\mathrm{a}}\right)$ dias após o plantio de milho...A, solos tratados com biossólido da ETE-Franca:...; B, solos tratados com biossólido da ETE-Barueri: Item 4.2.4, pgs. 102; 104, 106, 111, 115; Figura 21, Figura 22, Figura 23, Figura 25, Figura 26, Figura 27, respectivamente, onde se lê:...A, solos tratados com biossólido da ETE-Franca:...; ETEBarueri:... A e B, 30 dias após o plantio de milho; C e D, 60 dias após o plantio de milho., leia-se:...A, solos tratados com biossólido da ETE-Franca:..; $B$, solos tratados com biossólido da ETE-Barueri:...

Item 4.2.4, pgs 101; 102; 104; 106; 110; 111; 114; 115, Legenda:

onde se lê: $A R G\left(1^{a}\right)$, leia-se: solo argiloso $\left(1^{\mathrm{a}}\right)$

onde se lê: $A R G\left(2^{a}\right)$, leia-se: solo argiloso $\left(2^{a}\right)$

onde se lê: $\operatorname{ARE}\left(2^{\mathrm{a}}\right)$, leia-se: solo arenoso $\left(2^{\mathrm{a}}\right)$

onde se lê: $\operatorname{ARE}\left(1^{\mathrm{a}}\right)$, leia-se solo arenoso $\left(1^{\mathrm{a}}\right)$ 


\section{ERRATA}

Item 4.2.4, pg. 107, 1å 2alinha, onde se lê:...foram observadas variações nos indices,..., leia-se:... foram observadas variações nos índices,...

Item 4.2.4, pg 116, $2^{\circ} \S 1^{\text {alinha, }}$ onde se lê:....da diversidade têm extensivamente usadas...., leia-se:...da diversidade têm sido extensivamente usadas...

Item 4.2.5, pg 118, Tabela 14, onde se lê:...da região V3 do rDNA $16 S$ de Bacteria,..., leiase:... da região $\mathrm{V} 3$ do rDNA $16 \mathrm{~S}$ de Bacteria,.....

Item 4.2.5, pg $119,2^{\circ} \S 17^{\text {alinha, }}$ onde se lê:...Enterobacter, Klebisiela,..., leiase:...Enterobacter, Klebsiella

Ítem 4.2.5, pg 121, CONCLUSÕES, onde se lê:

- A estrutura da comunidade de Bacteria do solo tratado com biossólido com baixa concentração de metais pode ser alterada temporariamente;

- A estrutura da comunidade de Bacteria foi alterada com a aplicação de biossólidos com altas concentrações de metais pesados, porém os efeitos do distúrbio causado foram minimizados com o aumento do tempo de incubação;

- A estrutura da comunidade de Bacteria em solo arenoso foi mais sensivel a aplicação de altas concentrações de metais pesados.

leia-se:

- A estrutura e diversidade de Bacteria foram modificadas durante o cultivo do milho, em ambos os solos;

- Os indices de diversidade foram alterados em todos os tratamentos. Em solos tratados com biossólido contendo baixa concentração de metais, em geral, $\mathrm{S}$ e $\mathrm{H}$ aumentaram após 2 semanas de incubação. Já os valores de $D$ e $E$ foram reduzidos neste período. Somente os tratamentos que receberam a dose 4 sofreram aumento nos seus valores ao longo do tempo de incubação. Após 8 semanas todos os índices apresentaram valores semelhantes ao controle.

- Em solos argiloso e arenoso, foram observadas alterações na estrutura das comunidades de Bacteria. Nestes tratamentos, os coeficientes de similaridade e índices de diversidade variaram de 30 para 60 dias após o plantio do milho. Os valores de $S$ diferem especialmente com a aplicação da dose 3 do biossólido da. ETE-Barueri, com valores aproximados após 60 dias. Os valores de $\mathrm{H}$ permaneceram quase constante independente das doses de biossólido aplicadas, em ambos os solos. A dominância foi dependente da dose de biossólido aplicada, com maior aumento nas primeiras doses do biossólido de ETE-Franca. A eqüitabilidade foi também dependente da dose de biossólido aplicada, porém, os maiores valores foram observados em solo arenoso tratado com biossólido da ETE-Barueri.

- Os dois conjuntos de iniciadores utilizados, permitiram verificar variações na estrutura da comunidade. O conjunto formado pelos iniciadores BA63fGC / UN518r, foi menos sensível, mostrando pequenas diferenças entre os coeficientes de similaridade $e$ índices de diversidade. 


\section{Dados Internacionais de Catalogação na Publicação (CIP) DIVISĀO DE BIBLIOTECA E DOCUMENTAÇĀO - ESALQ/USP}

\section{Souza, Ângela Garcia de}

Diversidade e estrutura de comunidades de Bacteria em solos tratados com biossólidos I Ângela Garcia de Souza. - - Piracicaba, 2002.

136 p. : il.

Tese (doutorado) - Escola Superior de Agricultura Luiz de Queiroz, 2002. Bibliografia.

1. Bactéria do solo 2. Lodo de esgoto 3. Metal pesado 4. Propriedade de físicoquímica do solo 5. Química do solo I. Título

CDD 631.46 
Se as coisas são inatingíveis....Ora! NÃo É MOTIVO PARA NÂO QUERÊ-LAS.... QUE TRISTES OS CAMINHOS, SE NÃO FORA A DISTANTE PRESENÇA DAS ESTRELAS.

MÁRIO QUINTANA 


\section{A Deus pela presença \\ EM TODOS OS MOMENTOS;}

Agradeço

A minha família, PELO APOIO CONSTANTE E

AO MEU SOGRO, PELA GRANDE AJUDA E

Ao MEU QUerido Gilmar, PELA PACIENCIA E dedicação.

Ofereço

Ao

Dr. Marcio Rodrigues lambais, PELA OPORTUNIDADE

Dedico 


\section{AGRADECIMENTOS}

- Ao Prof. Dr. Marcio Rodrigues Lambais do Departamento de Solos e Nutrição de Plantas-ESALQ/USP, pela orientação;

- Ao Prof. Dr. Liuz Gonzaga do Prado Filho pela oportunidade para a realização deste trabalho;

- À coordenação do curso de pós-graduação em Agronomia: Microbiologia Agrícola, representada pelo Prof. Dr. Flávio Cesar Almeida Tavares, pela ajuda em todos os momentos;

- Aos técnicos do laboratório de Microbiologia Agrícola, Denise e Fernando, pelo auxílio e amizade;

- À todos os professores e colegas que ajudaram com algumas sugestões;

- Aos colegas do laboratório: Leandra, Winston, Elizabeth, Adriana Lorenzi, Beatriz, Daniele, lara, Taís, Robinson, Janaína, Adriana Pedroso, Simão, Juliano, Marco, pelas oportunidades de ajudar e aprender.

- Ao CNPq, pelo auxílio financeiro fornecido 


\section{SUMÁRIO}

Página

LISTA DE TABELAS....................................................................... viii

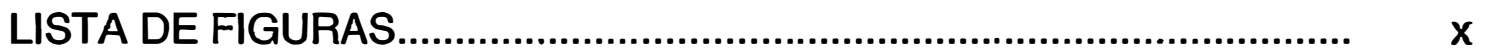

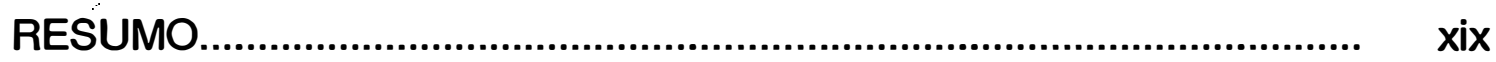

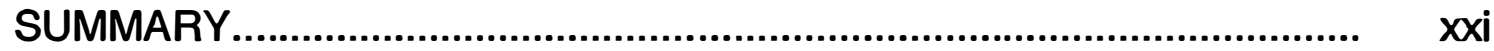

1 INTRODUÇÃO

2 REVISÃO DA LITERATURA.......................................................... 4

2.1 Biossólidos: geração, características e disposição................................. 4

2.2 Metais pesados e biossólidos.......................................................... 7

2.3 Efeito de biossólidos e metais na diversidade funcional dos solos...... $\quad 15$

2.4 Efeito de biossólidos e metais na diversidade genética e estrutura de comunidades microbianas dos solos.................................................. 18

2.5 Técnicas moleculares para estudo de comunidades microbianas dos

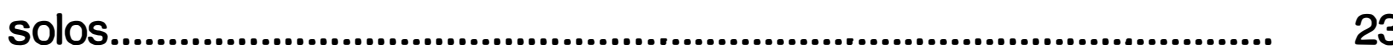

3 MATERIAL E MÉTODOS............................................................ 28

3.1 EXPERIMENTO 1: Alterações da estrutura da comunidade de Bacteria de um solo argiloso não-cultivado tratado com biossólido da ETE-Franca................................................................................. 28

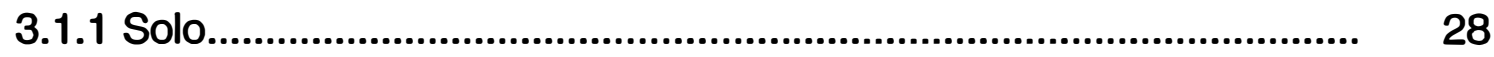

3.1.2 Biossólido................................................................................. 29

3.1.3 Delineamento experimental......................................................... 30 
3.1.4 Instalação condução do experimento.

3.2 EXPERIMENTO 2: Alterações da diversidade genética e estrutura das comunidades de Bacteria em solos cultivados com milho (Zea mays), após a aplicação de biossólidos.

3.2.1 Solos.

3.2.2 Biossólidos.

3.2.3 Delineamento experimental.

3.2.4 Instalação e condução do experimento.

3.3 Extração de DNA total do solo.

3.4 Amplificação do rDNA 16S por PCR.

3.5 Eletroforese em gel de poliacrilamida com gradiente desnaturante (DGGE)

3.6 Aquisição e análise de imagens dos géis

3.7 Análise da estrutura das comunidades de Bacteria.

3.8 Análise da diversidade genética das comunidades de Bacteria.

3.9 Caracterização dos amplicons.

4. RESULTADOS E DISCUSSÃO.

4.1 Experimento 1: Alterações da estrutura da comunidade de Bacteria em solo argiloso não-cultivado tratado com biossólido da ETEFranca.

4.1.1 Análises químicas e físicas do solo e biossólido utilizados.

4.1.2 Extração de DNA total do solo.

4.1.3 Amplificação de fragmentos do rDNA 16S.

4.1.4 Estrutura da comunidade de Bacteria.

4.1.5 Análise dos índices de diversidade.

4.2 Experimento 2: Allterações da estrutura da comunidade e diversidade de Bacteria em solos cultivados com milho (Zea mays), após a aplicação de biossólidos 64

4.2.1 Análises químicas e físicas dos solos e biossólidos utilizados. 


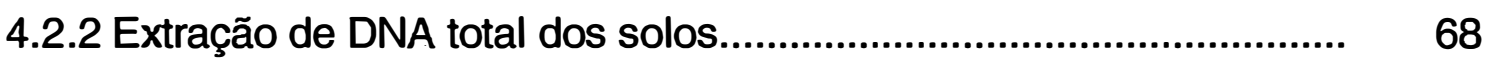

4.2.3 Amplificação de fragmentos do rDNA 16S....................................... 68

4.2.4 Estrutura da comunidade de Bacteria............................................. 70

4.2.5 Análise dos índices de diversidade................................................. 99

4.2.6 Seqüenciamento.................................................................... 116

5 CONCLUSÕES........................................................................ 121

REFERÊNCIAS BIBLIOGRÁFICAS................................................ 122 


\section{LISTA DE TABELAS}

Página

1. Características químicas e físicas do solo utilizado no experimento.

2. Características químicas do biossólido da ETE-Franca utilizado no experimento.

3. Taxa anual máxima de metais permitida pela Norma P4.230 da CETESB (Estado de São Paulo, 1999) e taxa de metais aplicados no solo, de acordo com as doses definidas

4. Qualidade do DNA total extraído do solo argiloso tratado com biossólido da ETE-Franca.

5. Coeficientes de similaridade binários ("simple matching") dos perfis de amplicons da região V3 do rDNA $16 S$ de Bacteria, nas quatro épocas de amostragem.

6. Características químicas e físicas dos solos utilizados no experimento

7. Características químicas dos biossólidos da ETE-Franca e ETEBarueri, utilizados no experimento.

8. Taxa anual máxima de metais permitida pela Norma P4.230 da CETESB (Estado de São Paulo, 1999) e taxa de metais aplicados no solo, de acordo com as doses definidas. 
9. Quantidade e qualidade do DNA total extraído de solo argiloso ou arenoso tratados com biossólido da ETE-Franca ou ETE-Barueri......

10. Coeficientes de similaridade binários ("simple matching") dos perfis de amplicons da região V3 do rDNA 16S de Bacteria, 30 dias após o plantio do milho

11. Coeficientes de similaridade binários ("simple matching") dos perfis de amplicons da região V3 do rDNA 16S de Bacteria, 60 dias após o plantio do milho.

12. Coeficientes de similaridade binários ("simple matching") dos perfis de amplicons da região V1-V3 do rDNA 16S de Bacteria, 30 dias após o plantio do milho

13. Coeficientes de similaridade binários ("simple matching") dos perfis de amplicons da região V1-V3 do rDNA 16S de Bacteria, 60 dias após o plantio do milho.

12. Nível de similaridade das seqüências de nucleotídeos dos amplicons da região V3 do rDNA 165 de Bacteria, com seqüências homólogas de vários organismos em bancos de dados identificados pela comparação das seqüências no programa BLAST 


\section{LISTA DE FIGURAS}

Página

1 - DNA total extraído das amostras de solo argiloso, tratadas com biossólido da ETE-Franca. M, marcador de massa molecular; Dose 1, sem adição de biossólido; Dose 2, $6 \mathrm{Mg} \mathrm{ha}^{-1}$; Dose 3, 12 $\mathrm{Mg} \mathrm{ha}^{-1}$, Dose 4, $24 \mathrm{Mg} \mathrm{ha}^{-1}$; Dose 5, $48 \mathrm{Mg} \mathrm{ha}^{-1}$. O tempo de incubação está expresso em semanas.

2 - Amplicons da região V3 do rDNA $16 S$ da comunidade de Bacteria de solo argiloso tratado com biossólido da ETE-Franca. M, marcador de massa molecular; $\mathrm{C}$, controle negativo, sem DNA; Dose 1, sem adição de biossólido; Dose 2, $6 \mathrm{Mg} \mathrm{ha}^{-1}$; Dose 3, 12 $\mathrm{Mg} \mathrm{ha}^{-1}$; Dose 4, $24 \mathrm{Mg} \mathrm{ha}^{-1}$; Dose 5, $48 \mathrm{Mg} \mathrm{ha}^{-1}$. O tempo de incubação está expresso em semanas

3 - Amplicons da região V3 do rDNA $16 S$ da comunidade de Bacteria em solo argiloso tratado com biossólido da ETE-Franca. Os amplicons foram separados em gel de poliacrilamida $8 \%$, com gradiente desnaturante (15-55\%). O DNA foi visualizado por coloração com SYBR Green I. Dose 1, sem adição de biossólido; Dose 2, $6 \mathrm{Mg} \mathrm{ha}^{-1}$; Dose 3, $12 \mathrm{Mg} \mathrm{ha}^{-1}$; Dose 4, $24 \mathrm{Mg} \mathrm{ha}^{-1}$; Dose $5,48 \mathrm{Mg} \mathrm{ha}^{-1}$. O tempo de incubação está expresso em semanas. C, controle (DNA do solo extraído na instalação do experimento, controle das condições de corrida). A amostra da dose 5 com 8 semanas de incubação (T4) foi perdida 
4 - Diagrama representando os amplicons da região V3 do rDNA $16 S$ da comunidade de Bacteria de solo argiloso tratado com biossólido da ETE-Franca. Dose 1, sem aplicação de biossólido; Dose 2, $6 \mathrm{Mg} \mathrm{ha}^{-1}$; Dose 3, $12 \mathrm{Mg} \mathrm{ha}^{-1}$; Dose 4, $24 \mathrm{Mg} \mathrm{ha}^{-1}$; Dose $5,48 \mathrm{Mg} \mathrm{ha}^{-1}$

5 - Dendograma mostrando as relações entre os amplicons da região V3 do rDNA 16S da comunidade de Bacteria de solo argiloso, tratado com biossólido da ETE-Franca $(F)$. Dose 1, sem aplicação de biossólido; Dose 2, $6 \mathrm{Mg} \mathrm{ha}^{-1}$; Dose 3, $12 \mathrm{Mg} \mathrm{ha}^{-1}$; Dose 4, 24 $\mathrm{Mg} \mathrm{ha}^{-1}$; Dose 5, $48 \mathrm{Mg} \mathrm{ha}^{-1}$.

6 - Índices de diversidade. A, Riqueza de espécies (S); B, Índice de Shannon-Weaver $(H)$ de solo argiloso tratado com biossólido da ETE-Franca calculados a partir dos dados de abundância relativa dos amplicons em função do tempo de incubação do solo. Dose 1, sem aplicação de biossólido; Dose 2, $6 \mathrm{Mg} \mathrm{ha}^{-1}$; Dose 3, $12 \mathrm{Mg}$ ha $^{-1}$; Dose 4, $24 \mathrm{Mg} \mathrm{ha}^{-1}$; Dose 5, $48 \mathrm{Mg} \mathrm{ha}^{-1}$; T1, 1 semana; T2, 2 semanas; T3, 4 semanas; T4, 8 semanas após a aplicação do biossólido.

7 - Índices de diversidade. A, Índice de dominância de Simpson (D); $B$, Índice de eqüitabilidade $(E)$ de solo argiloso tratado com biossólido da ETE-Franca calculados a partir dos dados de abundância relativa dos amplicons em função do tempo de incubação do solo. Dose 1, sem aplicação de biossólido; Dose 2, $6 \mathrm{Mg} \mathrm{ha}^{-1}$; Dose 3, $12 \mathrm{Mg} \mathrm{ha}^{-1}$; Dose 4, $24 \mathrm{Mg} \mathrm{ha}^{-1}$; Dose 5, $48 \mathrm{Mg}$ ha $^{-1}$; T1, 1 semana; T2, 2 semanas; T3, 4 semanas; T4, 8 semanas após a aplicação do biossólido. 
8 - DNA total extraído das amostras de solo argiloso e arenoso, tratados com biossólidos da ETE-Franca ou ETE-Barueri. M, marcador de massa molecular; Dose 1, sem adição de biossólido; ETE-Franca: Dose 2, $6 \mathrm{Mg} \mathrm{ha}^{-1}$; Dose 3, $24 \mathrm{Mg} \mathrm{ha}^{-1}$; Dose 4, 96 $\mathrm{Mg} \mathrm{ha}^{-1}$; ETE-Barueri: Dose 2, $31 \mathrm{Mg} \mathrm{ha}^{-1}$; Dose 3, $62 \mathrm{Mg} \mathrm{ha}^{-1}$; Dose 4, $124 \mathrm{Mg} \mathrm{ha}^{-1}$

9 - Amplicons sintetizados por PCR do rDNA 165 de Bacteria de solo argiloso e arenoso tratado com biossólidos da ETE-Franca ou ETE-Barueri. M, marcador de massa molecular; Dose 1, sem adição de biossólido; ETE-Franca: Dose 2, $6 \mathrm{Mg} \mathrm{ha}^{-1}$; Dose 3, 24 $\mathrm{Mg} \mathrm{ha}^{-1}$; Dose 4, $96 \mathrm{Mg} \mathrm{ha}^{-1}$; ETE-Barueri: Dose 2, $31 \mathrm{Mg} \mathrm{ha}^{-1}$; Dose 3, $62 \mathrm{Mg} \mathrm{ha}^{-1}$; Dose 4, $124 \mathrm{Mg} \mathrm{ha}^{-1}$. A, região V3; B, região V1-V3

10 - Amplicons da região V3 do rDNA $16 S$ das comunidades de Bacteria de solo argiloso e arenoso, tratados com biossólidos da ETE-Franca ou ETE-Barueri. Os amplicons foram separados em gel de poliacrilamida $8 \%$, com gradiente desnaturante (15$55 \%$ ). O DNA foi visualizado por coloração com SYBR Green I. Dose 1, sem adição de biossólido; ETE-Franca: Dose 2, $6 \mathrm{Mg}$ ha $^{-1}$; Dose 3, $24 \mathrm{Mg} \mathrm{ha}^{-1}$; Dose 4, $96 \mathrm{Mg} \mathrm{ha}^{-1}$; ETE-Barueri: Dose 2, $31 \mathrm{Mg} \mathrm{ha}^{-1}$; Dose 3, $62 \mathrm{Mg} \mathrm{ha}^{-1}$; Dose 4, $124 \mathrm{Mg} \mathrm{ha}^{-1}$. Amostras coletadas 30 dias após o plantio do milho. As setas indicam os amplicons seqüênciados

11 - Diagrama representando os amplicons da região V3 do rDNA $16 S$ das comunidades de Bacteria de solo argiloso e arenoso, tratados com biossólidos da ETE-Franca ou ETE-Barueri. Dose 1, sem adição de biossólido; ETE-Franca: Dose 2, $6 \mathrm{Mg} \mathrm{ha}^{-1}$; Dose 3, $24 \mathrm{Mg} \mathrm{ha}^{-1}$; Dose 4, $96 \mathrm{Mg} \mathrm{ha}^{-1}$; ETE-Barueri: Dose 2, $31 \mathrm{Mg}$ ha $^{-1}$; Dose 3, $62 \mathrm{Mg} \mathrm{ha}^{-1}$; Dose 4, $124 \mathrm{Mg} \mathrm{ha}^{-1}$. Amostras coletadas 30 dias após o plantio do milho 
12 - Amplicons da região V3 do rDNA $16 S$ das comunidades de Bacteria de solo argiloso e arenoso tratado com biossólido da ETE-Franca e ETE-Barueri. Os amplicons foram separados em gel de poliacrilamida $8 \%$, com gradiente desnaturante (15-55\%). O DNA foi visualizado por coloração com SYBR Green I. Dose 1, sem adição de biossólido; ETE-Franca: Dose 2, $6 \mathrm{Mg} \mathrm{ha}^{-1}$; Dose 3, $24 \mathrm{Mg} \mathrm{ha}^{-1}$; Dose 4, $96 \mathrm{Mg} \mathrm{ha}^{-1}$; ETE-Barueri: Dose 2, $31 \mathrm{Mg} \mathrm{ha}^{-1}$; Dose 3, $62 \mathrm{Mg} \mathrm{ha}^{-1}$; Dose 4, $124 \mathrm{Mg} \mathrm{ha}^{-1}$. As amostras foram coletadas 60 dias após o plantio de milho. As setas indicam os amplicons seqüênciados.

13 - Diagrama representando os amplicons da região V3 do rDNA 16S das comunidades de Bacteria de solo argiloso e arenoso, tratados com biossólidos da ETE-Franca ou ETE-Barueri. Dose 1, sem adição de biossólido; ETE-Franca: Dose 2, $6 \mathrm{Mg} \mathrm{ha}^{-1}$; Dose 3, $24 \mathrm{Mg} \mathrm{ha}^{-1}$; Dose 4, $96 \mathrm{Mg} \mathrm{ha}^{-1}$; ETE-Barueri: Dose 2, $31 \mathrm{Mg}$ $\mathrm{ha}^{-1}$; Dose 3, $62 \mathrm{Mg} \mathrm{ha}^{-1}$; Dose 4, $124 \mathrm{Mg} \mathrm{ha}^{-1}$. Amostras coletadas 60 dias após o plantio do milho.....................................

14 - Dendograma mostrando as relações entre os amplicons sintetizados por PCR com os iniciadores BA338fGC e UN518r de solo argiloso (ARG) ou arenoso (ARE) tratados com biossólidos. Dose 1, sem adição de biossólido; (ARGD0; ARED0); ETE-Franca: Dose 2, $6 \mathrm{Mg} \mathrm{ha}^{-1}$; Dose 3, $24 \mathrm{Mg} \mathrm{ha}^{-1}$; Dose 4, $96 \mathrm{Mg} \mathrm{ha}^{-1}$; ETE-Barueri: Dose 2, $31 \mathrm{Mg} \mathrm{ha}^{-1}$; Dose 3, $62 \mathrm{Mg} \mathrm{ha}^{-1}$; Dose 4, $124 \mathrm{Mg} \mathrm{ha}^{-1}$. A e B, 30 dias após o plantio do milho; $C$ e D, 60 dias após o plantio do milho 
15 - Amplicons da região V1-V3 do rDNA $16 \mathrm{~S}$ das comunidades de Bacteria de solo argiloso e arenoso, tratados com biossólidos da ETE-Barueri ou ETE-Franca. Os amplicons foram separados em gel de. poliacrilamida $6 \%$, com gradiente desnaturante (10-45\%). O DNA foi visualizado por coloração com SYBR Green I. Dose 1, sem adição de biossólido; ETE-Franca: Dose 2, $6 \mathrm{Mg} \mathrm{ha}^{-1}$; Dose 3, $24 \mathrm{Mg} \mathrm{ha}^{-1}$; Dose 4, $96 \mathrm{Mg} \mathrm{ha}^{-1}$; ETE-Barueri: Dose 2, $31 \mathrm{Mg}$ $\mathrm{ha}^{-1}$; Dose 3, $62 \mathrm{Mg} \mathrm{ha}^{-1}$; Dose 4, $124 \mathrm{Mg} \mathrm{ha}^{-1}$. As amostras foram coletadas 30 dias após o plantio de milho

16 - Diagrama representando os amplicons da região V1-V3 do rDNA $16 S$ das comunidades de Bacteria de solo argiloso e arenoso, tratados com biossólidos da ETE-Franca ou ETE-Barueri. Dose 1, sem adição de biossólido; ETE-Franca: Dose 2, $6 \mathrm{Mg} \mathrm{ha}^{-1}$; Dose: 3, $24 \mathrm{Mg} \mathrm{ha}^{-1}$; Dose 4, $96 \mathrm{Mg} \mathrm{ha}^{-1}$; ETE-Barueri: Dose 2, $31 \mathrm{Mg}$ ha $^{-1}$; Dose 3, $62 \mathrm{Mg} \mathrm{ha}^{-1}$; Dose 4, $124 \mathrm{Mg} \mathrm{ha}^{-1}$. Amostras coletadas 30 dias após o plantio do milho........................................

17 - Amplicons da região V1-V3 do rDNA $16 \mathrm{~S}$ das comunidades de Bacteria de solo argiloso e arenoso, tratados com biossólidos da ETE-Barueri ou ETE-Franca. Os amplicons foram separados em gel de poliacrilamida $6 \%$, com gradiente desnaturante $(10-45 \%)$. O DNA foi visualizado por coloração com SYBR Green I. Dose 1, sem adição de biossólido; ETE-Franca: Dose 2, $6 \mathrm{Mg} \mathrm{ha}^{-1}$; Dose 3, $24 \mathrm{Mg} \mathrm{ha}^{-1}$; Dose 4, $96 \mathrm{Mg} \mathrm{ha}^{-1}$; ETE-Barueri: Dose 2, $31 \mathrm{Mg}$ ha $^{-1}$; Dose 3, $62 \mathrm{Mg} \mathrm{ha}^{-1}$; Dose 4, $124 \mathrm{Mg} \mathrm{ha}^{-1}$. As amostras foram coletadas 60 dias após o plantio de milho 
18 - Diagrama representando os amplicons da região V1-V3 do rDNA $16 S$ das comunidades de Bacteria de solo argiloso e arenoso, tratados com biossólidos da ETE-Franca ou ETE- Barueri. Dose 1, sem adição de biossólido; ETE-Franca: Dose 2, $6 \mathrm{Mg} \mathrm{ha}^{-1}$; Dose 3, $24 \mathrm{Mg} \mathrm{ha}^{-1}$; Dose 4, $96 \mathrm{Mg} \mathrm{ha}^{-1}$; ETE-Barueri: Dose 2, 31 $\mathrm{Mg} \mathrm{ha}^{-1}$; Dose 3, $62 \mathrm{Mg} \mathrm{ha}^{-1}$; Dose 4, $124 \mathrm{Mg} \mathrm{ha}^{-1}$. Amostras coletadas 60 dias após o plantio do milho......................................

19 - Dendograma mostrando as relações entre os amplicons sintetizados por PCR com os iniciadores BA63fGC e UN518r. Análise de agrupamento para as amostras de solo argiloso (ARG) e arenoso (ARE), tratados com biossólidos da ETEBarueri ou ETE-Franca. Dose 1, sem adição de biossólido; (ARGDO; ARED0); ETE-Franca: Dose 2, $6 \mathrm{Mg} \mathrm{ha}^{-1}$; Dose 3, 24 $\mathrm{Mg} \mathrm{ha}^{-1}$; Dose 4, $96 \mathrm{Mg} \mathrm{ha}^{-1}$; ETE-Barueri: Dose 2, $31 \mathrm{Mg} \mathrm{ha}^{-1}$; Dose 3, $62 \mathrm{Mg} \mathrm{ha}^{-1}$; Dose 4, $124 \mathrm{Mg} \mathrm{ha}^{-1}$. A e B, 30 dias após o plantio do milho; $C$ e D, 60 dias após o plantio do milho.............

20 - Índice de diversidade dos amplicons da região V3 do rDNA $16 S$. Riqueza de espécies (S) em solo argiloso (ARG) ou arenoso (ARE), em função da dose de biossólido adicionada, avaliada 30(1) e 60(2) dias após o plantio de milho. Os valores de $S$ foram calculados a partir dos dados de abundância relativa dos amplicons. A, solos tratados com biossólido da ETE-Franca: Dose 2, $6 \mathrm{Mg} \mathrm{ha}^{-1}$; Dose 3, $24 \mathrm{Mg} \mathrm{ha}^{-1}$; Dose 4, $96 \mathrm{Mg} \mathrm{ha}^{-1} ; \mathrm{B}$, solos tratados com biossólido da ETE-Barueri: Dose 2, $31 \mathrm{Mg}$ ha $^{-1}$; Dose 3, $62 \mathrm{Mg} \mathrm{ha}^{-1}$; Dose 4, $124 \mathrm{Mg} \mathrm{ha}^{-1}$ 
21 - Índice de diversidade dos amplicons da região V3 do rDNA 165. Índice de Shannon-Weaver $(H)$ em solo argiloso (ARG) ou arenoso (ARE), em função da da dose de biossólido adicionada, avaliada $30(1)$ e 60(2) dias após o plantio de milho. Os valores de $\mathrm{H}$ foram calculados a partir dos dados de abundância relativa dos amplicons. A, solos tratados com biossólido da ETE-Franca: Dose 2, $6 \mathrm{Mg} \mathrm{ha}^{-1}$; Dose 3, $24 \mathrm{Mg} \mathrm{ha}^{-1}$; Dose 4, $96 \mathrm{Mg} \mathrm{ha}^{-1} ;$;B, solos tratados com biossólido da ETE-Barueri: Dose 2, $31 \mathrm{Mg} \mathrm{ha}^{-}$ 1; Dose 3, $62 \mathrm{Mg} \mathrm{ha}^{-1}$; Dose 4, $124 \mathrm{Mg} \mathrm{ha}^{-1}$

22 - Índice de diversidade dos amplicons da região V3 do rDNA 165. Índice de dominância de Simpson (D) em solo argiloso (ARG) ou arenoso (ARE), em função da da dose de biossólido adicionada, avaliada 30(1) e 60(2) dias após o plantio de milho. Os valores de $\mathrm{D}$ foram calculados a partir dos dados de abundância relativa dos amplicons. A, solos tratados com biossólido da ETE-Franca: Dose 2, $6 \mathrm{Mg} \mathrm{ha}^{-1}$; Dose 3, $24 \mathrm{Mg} \mathrm{ha}^{-1}$; Dose 4, $96 \mathrm{Mg} \mathrm{ha}^{-1}$;;B, solos tratados com biossólido da ETE-Barueri: Dose 2, $31 \mathrm{Mg}$ ha $^{-1}$; Dose 3, $62 \mathrm{Mg} \mathrm{ha}^{-1}$; Dose 4, $124 \mathrm{Mg} \mathrm{ha}^{-1}$

23 - Índice de diversidade dos amplicons da região V3 do rDNA 16S. Índice de eqüitabilidade (E) em solo argiloso (ARG) ou arenoso (ARE), em função da da dose de biossólido adicionada, avaliada $30(1)$ e 60 (2) dias após o plantio de milho. Os valores de $E$ foram calculados a partir dos dados de abundância relativa dos amplicons: A, solos tratados com biossólido da ETE-Franca: Dose 2, $6 \mathrm{Mg} \mathrm{ha}^{-1}$; Dose 3, $24 \mathrm{Mg} \mathrm{ha}^{-1}$; Dose 4, $96 \mathrm{Mg} \mathrm{ha}^{-1}$;;B, solos tratados com biossólido da ETE-Barueri: Dose 2, $31 \mathrm{Mg}$ ha $^{-1}$; Dose 3, $62 \mathrm{Mg} \mathrm{ha}^{-1}$; Dose 4, $124 \mathrm{Mg} \mathrm{ha}^{-1}$ 
24 - Índice de diversidade dos amplicons da região V1-V3 do rDNA 16S. Riqueza de espécies (S) em solo argiloso (ARG) ou arenoso (ARE), em função da da dose de biossólido adicionada, avaliada $30(1)$ e 60(2) dias após o plantio de milho. Os valores de $S$ foram calculados a partir dos dados de abundância relativa dos amplicons. A, solos tratados com biossólido da ETE-Franca: Dose 2, $6 \mathrm{Mg} \mathrm{ha}^{-1}$; Dose 3, $24 \mathrm{Mg} \mathrm{ha}^{-1}$; Dose 4, $96 \mathrm{Mg} \mathrm{ha}^{-1} ;$;B, solos tratados com biossólido da ETE-Barueri: Dose 2, $31 \mathrm{Mg}$ ha $^{-1}$; Dose 3, $62 \mathrm{Mg} \mathrm{ha}^{-1}$; Dose 4, $124 \mathrm{Mg} \mathrm{ha}^{-1}$

25 - Índice de diversidade dos amplicons da região V1-V3 do rDNA 16S. Índice de Shannon-Weaver (H) em solo argiloso (ARG) ou arenoso (ARE), em função da da dose de biossólido adicionada, avaliada 30(1) e 60(2) dias após o plantio de milho. Os valores de $\mathrm{H}$ foram calculados a partir dos dados de abundância relativa dos amplicons. A, solos tratados com biossólido da ETE-Franca: Dose 2, $6 \mathrm{Mg} \mathrm{ha}^{-1}$; Dose 3, $24 \mathrm{Mg} \mathrm{ha}^{-1}$; Dose 4, $96 \mathrm{Mg} \mathrm{ha}^{-1} ; \mathrm{B}$, solos tratados com biossólido da ETE-Barueri: Dose 2, $31 \mathrm{Mg} \mathrm{ha}^{-}$ 1; Dose 3, $62 \mathrm{Mg} \mathrm{ha}^{-1}$; Dose 4, $124 \mathrm{Mg} \mathrm{ha}^{-1}$.

26 - Índice de diversidade dos amplicons da região V1-V3 do rDNA 16S. Índice de dominância (D) em solo argiloso (ARG) ou arenoso (ARE), em função da da dose de biossólido adicionada, avaliada 30(1) e 60(2) dias após o plantio de milho. Os valores de $D$ foram calculados a partir dos dados de abundância relativa dos amplicons. A, solos tratados com biossólido da ETE-Franca: Dose 2, $6 \mathrm{Mg} \mathrm{ha}^{-1}$; Dose 3, $24 \mathrm{Mg} \mathrm{ha}^{-1}$; Dose 4, $96 \mathrm{Mg} \mathrm{ha}^{-1} ; \mathrm{B}$, solos tratados com biossólido da ETE-Barueri: Dose 2, $31 \mathrm{Mg} \mathrm{ha}^{-}$ 1; Dose 3, $62 \mathrm{Mg} \mathrm{ha}^{-1}$; Dose 4, $124 \mathrm{Mg} \mathrm{ha}^{-1}$ 
27 - Índice de diversidade dos amplicons da região V1-V3 do rDNA 16S. Índice de eqüitabilidade (E) em solo argiloso (ARG) ou arenoso (ARE), em função da da dose de biossólido adicionada, avaliada 30(1) e 60(2) dias após o plantio de milho. Os valores de $S$ foram calculados a partir dos dados de abundância relativa dos amplicons. A, solos tratados com biossólido da ETE-Franca: Dose 2, $6 \mathrm{Mg} \mathrm{ha}^{-1}$; Dose 3, $24 \mathrm{Mg} \mathrm{ha}^{-1}$; Dose 4, $96 \mathrm{Mg} \mathrm{ha}^{-1} ;$;B, solos tratados com biossólido da ETE-Barueri: Dose_2,. $31 \mathrm{Mg}$. ha $^{-1}$; Dose 3, $62 \mathrm{Mg} \mathrm{ha}^{-1}$; Dose 4, $124 \mathrm{Mg} \mathrm{ha}^{-1}$

28 - Relações filogenéticas entre os amplicons seqüênciados e seqüências depositadas no GenBank........................................... 


\title{
DIVERSIDADE E ESTRUTURA DE COMUNIDADES DE BACTERIA EM SOLOS TRATADOS COM BIOSSÓLIDOS
}

\author{
Autora: Ângela Garcia de Souza \\ Orientador: Prof. Dr. Marcio Rodrigues Lambais
}

\section{RESUMO}

\begin{abstract}
A utilização de biossólidos como fonte de nutrientes vegetais e/ou como condicionador da estrutura de solos agrícolas tem sido amplamente preconizada. Embora seu efeito benéfico para as plantas seja inquestionável, muito pouco se sabe sobre seu impacto sobre a microbiota dos solos. Dependendo de sua origem, biossólidos podem conter altas concentrações de metais e agentes antimicrobianos, os quais podem interferir na fisiologia da microbiota, modificando a estrutura da comunidade microbiana dos solos. Como a biodiversidade dos solos pode estar associada à sua qualidade, o impacto da aplicação de biossólidos aos solos. deve ser mais estudado. Neste trabalho, alterações da diversidade genética e da estrutura da comunidade de Bacteria de solos tratados com biossólidos de duas ETEs do Estado de São Paulo foram avaliadas pela técnica de eletroforese em gel de poliacrilamida com gradiente desnaturante (DGGE). No primeiro experimento, foram avaliadas as alterações
\end{abstract}


na diversidade genética e estrutura da comunidade de Bacteria de um NITOSSOLO VERMELHO Eutroférrico típico, ao longo do tempo $(0 ; 1 ; 2 ; 4$ e 8 semanas) após a aplicação do biossólido da ETE-Franca em quantidades equivalentes a $6 ; 12,24$ e $48 \mathrm{Mg} \mathrm{ha}^{-1}$ além de um controle sem adição de biossólido. No segundo experimento, foi avaliado o impacto da aplicação de biossólidos da ETE-Franca e ETE-Barueri, caracterizados pela alta e baixa concentração de metais pesados, respectivamente, em dois tipos de solo (NEOSSOLO QUARTZARÊNICO Órtico típico e NITOSSOLO VERMELHO Eutroférrico típico), cultivados com milho, sobre a diversidade genética e estrutura da comunidade de Bacteria. O biossólido da ETE-Franca foi utilizado em quantidades equivalentes a 6; 24; $96 \mathrm{Mg} \mathrm{ha}^{-1}$. Já o biossólido da ETEBarueri foi utilizado em quantidades equivalentes a 31; $62 ; 124 \mathrm{Mg} \mathrm{ha}^{-1}$ além de um controle sem adição de biossólido para cada tipo de solo. Os resultados demonstraram que a aplicação de biossólido com baixa concentração de metais pesados foi capaz de modificar a estrutura da comunidade de Bacteria, que se restabeleceu com o tempo. Os índices de diversidade demonstraram as variações na estrutura da comunidade com aumentos da riqueza de espécies e diversidade no inicio do experimento e maior dominância após 8 semanas, sendo indicativo da resiliência. No segundo experimento, foram detectadas variações nos amplicons de DGGE, demonstrando que a estrutura da comunidade de Bacteria foi alterada em relação às doses e tipo de biossólido e tipo de solos utilizados. Solos tratados com o biossólido da ETE-Franca tiveram maior similaridade com os controles sem biossólido. Quando tratados com biossólido da ETE-Barueri, a estrutura da comunidade de Bacteria foi alterada, sendo maior o efeito em solos arenosos. Os índices de diversidade em geral sofreram grandes modificações, entre 30 e 60 dias após o plantio de milho, com alta variabilidade nos valores de $\mathrm{S}$ (riqueza de espécies). $\mathrm{H}$ (diversidade) foi quase constante e $\mathrm{D}$ (dominância) e $\mathrm{E}$ (eqüitabilidade) são dependentes das doses de biossólidos aplicadas. 


\title{
DIVERSITY AND STRUCTURE OF BACTERIA COMMUNITIES IN SOILS AMENDED WITH BIOSSOLIDS
}

\author{
Author: Ângela Garcia de Souza \\ Adviser: Prof. Dr. Marcio Rodrigues Lambais
}

\section{SUMMARY}

The use of biosolids as a source of vegetables nutrients and/or as a conditioner of soil structure has been extensively recommended. Although their beneficial effects on improving vegetables growth are unquestioned, not enough details of their impact over soils with microorganisms are known. According to their origins biosolids may contain high concentrations of metals and antimicrobial compounds, which may affect the physiology of microorganisms changing the structure of soil microbial communities. Since soil biodiversity may be related to its quality, the impact of biosolids application in agricultural soils must be characterized. In this research, it has been examined the changes in genetic diversities and structure microbial communities of soil amended with biossolids of two Treatment Stations ( ETEs ) in São.Paulo. It has been used the method of electrophorese in poliacrilamida desnaturig gradient gel (DGGE). In the first experiment, it has been examined the changes in the diversitiy and communities structure of Bacteria of NITOSSOLO VERMELHO Eutroférrico típico, along ( $0 ; 1 ; 2 ; 4$ e 8 weeks) after the application of biossolids from ETE- 
Franca in amounts of $6 ; 12 ; 24 ; 48 \mathrm{Mg} \mathrm{ha}^{-1}$ beyond the control on a sample without biossolids. In the second experiment, it has been evaluated the impact of biossolids application from ETE-Barueri and ETE-Franca, with high and low concentration of heavy metals, respectively in two kinds of soils (NEOSSOLO QUARTZARÊNICO Órtico tipic e NITOSSOLO VERMELHO Eutroférrico tipic), begotten in com maize, in the diversities and communities structure of Bacteria. In the biossolids from ETE-Franca it has been used amounts of $6 ; 24 ; 96 \mathrm{Mg} \mathrm{ha}^{-}$ ${ }^{1}$ and in the biossolids from ETE-Barueri the amounts have been of $31 ; 62 ; 124$ $\mathrm{Mg} \mathrm{ha}^{-1}$ and one soil control with no addition of biossolids in both of the cases. The results have shown that the amending of biossolids with low concentration of heavy metals has been capable to modify the communities structure of Bacteria restored along the time. The diversities index have shown that the changes in the structure of Bacteria communities brought an improvement of soil in the beginning of the experiment and more effectively after 8 weeks have shown the resilience of systems. In the second experiment, it has been detected many changes in fingerprints of DGGE, showing that the structure of Bacteria communities has been modified according to kind and doses of biossolids and soil which have been used. Soils amended with biossolids from ETE-Franca have presented more similarities with soil without biossolids. When the soils have been amended with biossolids from ETE-Barueri the structure of Bacteria communities have been modified. That has happened more effectively in sandy soils. The diversity index suffered great changes between 30 and 60 days after the plantation of maize, showing much variation of $S$ (richnees). $H$ (diversity) has been nearly constant. The index $D$ (dominancy) and $E$ (evenness) depend on how much biossolids have been applied. 


\section{INTRODUÇÃO}

A produção de alimentos em grande escala deve ser compatível com a manutenção da qualidade ambiental. Neste contexto o sistema solo deve ser um meio para o desenvolvimento e conservação da saúde de plantas, animais e do homem (Banerjee et al., 1997). A qualidade de um solo é fundamental para a determinação de sua sustentabilidade e produtividade (Kennedy \& Smith, 1995).

Os solos brasileiros são na sua maioria ácidos e distróficos, apresentando baixas concentrações de nutrientes. Estas características, somadas ao manejo inadequado, podem causar problemas nutricionais para as plantas e afetar a atividade microbiana (Tsai et al., 1992). A microbiota do solo é o componente biológico mais significativo para a manutenção da sua qualidade, já que é o agente catalítico responsável pelas principais transformações da matéria orgânica e solubilização de macro e micronutrientes (Banerjee et al., 1997). A baixa taxa de reposição de nutrientes e corretivos, bem como, o intenso revolvimento, pode contribuir para a redução da atividade microbiana e resultar na sua degradação, comprometendo sua capacidade produtiva (Bending et al., 2000).

Novas práticas de manejo agrícola preconizam a adição de matéria orgânica para minimizar os distúrbios causados pelos sistemas de cultivo tradicionais, o que contribui para a melhoria de processos físicos, químicos e 
biológicos dos agrossistemas (Vortmann \& Wagner, 1987). Assim sendo, o uso agrícola de biossólidos pode ser uma prática importante para aumentar a concentração de matéria orgânica dos solos tropicais e contribuir para o aumento da sua produtividade. A aplicação de biossólidos em áreas agrícolas é uma estratégia bem sucedida, principalmente nos EUA, onde podem ser observados aumentos significativos na produtividade das culturas (Parr \& Hornick, 1993). Biossólidos podem também ser utilizados na recuperação de áreas degradadas, pois restauram as propriedades físicas e químicas dos solos.

Biossólidos, quando adicionados ao solo, fornecem macro e micronutrientes, aumentam a capacidade de retenção de água e aumentam a estabilidade de agregados (Paul \& Clarck, 1996). Por outro lado, biossólidos podem conter metais pesados, que são incorporados na cadeia alimentar. Aumentos significativos nas concentrações de metais pesados em solos resultantes da constante adição de biossólidos, oriundọs de Estações de Tratamento de Esgotos (ETEs), foram observados por McGrath (1994). Por outro lado, solos com alto teor de matéria orgânica podem adsorver maiores quantidades de metais pesados, diminuindo sua disponibilidade (Schulten \& Leinweber, 2000). A disponibilidade de metais pesados no solo e seu efeito sobre a biota, dependem tanto da quantidade quanto da qualidade da matéria orgânica adicionada (Banerjee et al., 1997). Porém, alta concentração de metais pode diminuir a capacidade metabólica da microbiota dos solos.

Embora poucos trabalhos tenham sido feitos em condições tropicais, especialmente no Brasil, a análise do efeito de biossólidos contendo metais nas comunidades bacterianas de solos agrícolas, pode contribuir significativamente para a avaliação do impacto causado pela adição de biossólidos ricos em metais em solos agrícolas. A análise de amplicons do gene que codifica o rRNA $16 S$ por eletroforese em gel de poliacrilamida com gradiente desnaturante 
(DGGE), pode ser uma importante ferramenta para o estudo de populações bacterianas complexas, pois permite o monitoramento de bactérias cultiváveis e não-cultiváveis (Muyzer et al., 1993; Øvreås et al., 1997). Isto favorece o estudo da estrutura das comunidades do solo ou de populações específicas como fixadores de nitrogênio, redutores de sulfato, entre outros.

Os objetivos deste trabalho são: (i) determinar alterações na estrutura da comunidade e diversidade genética de Bacteria de um solo agrícola não-cultivado, após a aplicação de biossólido com baixa concentração de metais; (ii) determinar alterações na diversidade genética e estrutura de comunidades de Bacteria em solos tratados com biossólidos contendo alta e baixa concentração de metais pesados, cultivados com milho. 


\section{REVISÃO DA LITERATURA}

\subsection{Biossólidos: geração, características e disposição}

Todas as atividades humanas são geradoras de resíduos, sendo sua qualidade e quantidade variável ao longo do tempo em função de aspectos sócio-econômicos, culturais e geográficos. O aumento da população nos grandes centros urbanos, no Brasil e no mundo, refletiu-se diretamente no volume de resíduos líquidos e sólidos produzidos diariamente. O tratamento biológico dos resíduos líquidos, gera uma massa de sólidos sedimentaveis constituída, principalmente de células microbianas chamada de lodo ou biossólido. Aproximadamente 29 milhões de toneladas de biossólidos são gerados anualmente nos Estados Unidos e Europa, dos quais somente $26 \%$ e $39 \%$ são reciclados, respectivamente, conforme dados do Projeto Tietê (1998). $\mathrm{Na}$ região metropolitana de São Paulo, a produção prevista de biossólidos, em base seca, será de 785 toneladas por dia, em 2015 (Tsutya, 2000).

As ETEs, recebem os efluentes líquidos urbanos provenientes de áreas residenciais e/ou industriais. A matéria orgânica dos efluentes é separada e estabilizada por diferentes processos, podendo ter dispoșição final variada. Entre as possibilidades de disposição dos biossólidos estão: aterro sanitário ou exclusivo, disposição em solos agrícolas, lançamento no mar (após sua estabilização) e incineração (Gonçalves \& Ludovice, 2000). O Plano Diretor de Lodos da SABESP prevê três destinos: disposição em aterros exclusivos, uso agrícola e incineração (Tsutya, 2000). 
O aterro sanitário pode causar poluição do ar (pela exalação de odores, fumaça, gases tóxicos ou material particulado), das águas superficiais (pelo escoamento de líquidos percolados ou carregamento de resíduos pela ação das águas da chuva), do solo e das águas subterrâneas (pela infiltração de líquidos percolados) (Hall, 1998). Além disso, os aterros sanitários necessitam de grandes áreas com características topográficas adequadas, para instalação. No caso de aterros exclusivos, tem-se a vantagem da disposição do biossólido na forma de tortas desidratadas quimicamente, com aplicação de cal virgem 60\% em massa (Tsutya, 2000). A disposição em aterros sanitários ou aterros exclusivos, bem como a incineração, requerem tecnologias sofisticadas e podem apresentar alto custo por tonelada tratada (Gonçalves \& Luduvice, 2000). O uso agrícola de biossólidos tem se mostrado, dentro do panorama mundial, como uma solução adequada do ponto de vista técnico, econômico e ambiental, pois promove a reciclagem de nutrientes, confere melhorias físicas e biológicas aos solos e acima de tudo, representa uma solução para minimizar o problema da disposição de grandes quantidades de biossólidos gerados.

Os biossólidos possuem aproximadamente $10-20 \%$ de sólidos, dos quais cerca de $70 \%$ estão na forma orgânica (Imhoff \& Imhoff, 1985). Este material pode ser submetido a processos aeróbios ou anaeróbios de estabilização, gerando produtos finais com características diferenciadas (Gonçalves \& Luduvice, 2000). A presença de maçonutrientes como N, P e K é o que possibilita o uso dos biossólidos como insumo agrícola potencial. Além de servir como fonte de nutrientes, os biossólidos podem aumentar o teor de matéria orgânica, a CTC e o pH dos solos (Khan \& Scullion, 2000). O aumento na estabilidade de agregados, a diminuição do alumínio trocável, a melhoria na estrutura do solo, bem como o aumento na produção de matéria seca e produtividade das culturas, são benefícios do uso agrícola do biossólido (Obbard, 2001). As melhorias na fertilidade e nas propriedades físicas do solo foram reconhecidas por Chander et al. (1995), os quais enfatizam os efeitos dos 
biossólidos nas propriedades biológicas do solo, medidas através da atividade respiratória, biomassa e número de células microbianas. Carmo (2000) avaliou o impacto de metais pesados, presente em biossólidos, sobre parâmetros biológicos. Os resultados mostraram que a aplicação de biossólido modifica o $\mathrm{pH}$, altera a atividade microbiana, especialmente no período em que o processo de degradação da matéria orgânica esta ocorrendo. Apesar dos efeitos benéficos, um dos problemas associados à aplicação agrícola de biossólidos é o enriquecimento do solo em metais, causando toxidez a plantas e microrganismos, além da possibilidade de introdução de patógenos humanos (Fließbach et al., 1994). Griffiths et al. (2001) determinaram a sensibilidade relativa da estabilidade funcional e indicadores potenciais do estado biológico do solo, para serem usados na detecção das alteração resultantes de diferentes fontes de impactos. A estabilidade funcional das populações de protozoários e a cinética de mineralização de substrato foram medidas em duplicatas de solos tratados com alta ou baixa diversidade de plantas, poluído ou não com hidrocarbonetos, com prática de manejo intensiva ou extensiva. Os resultados mostraram que a cinética de mineralização do substrato foi significativamente estimulada pela poluição por hidrocarboneto, diferindo do controle. A estabilidade funcional forneceu dados quantitativos sobre a resistência do solo ao distúrbio imposto, diferenciando os tratamentos.

Os riscos associados à aplicação de biossólidos em solos agrícolas têm sido avaliados nos Estados Unidos, Austrália e países da Comunidade Européia. Nos Estados Unidos e Austrália, os limites de substâncias poluentes nos biossólidos são fixados com base na idéia de administrar um risco ambiental aceitável. Procede-se a análise da exposição ao risco e das respostas às doses aplicadas, caracterizando-se o risco pela probabilidade $\mathrm{e}$ calculando a concentração que causaria a primeira indicação de toxidez às plantas cultivadas (Santos \& Tsutya, 1998). 
$\mathrm{Na}$ Comunidade Européia, as bases para o uso controlado de biossólidos na agricultura foram estabelecidas pela implementação da Diretriz da Comunidade Européia 86/278/EEC em 1989, após anos de negociação e de consideráveis pesquisas (Hall, 1998). Os limites de potenciais poluentes introduzidos no solo através dos biossólidos se baseiam em suas concentrações no solo antes da aplicação dos mesmos (Santos et al., 1997). Consideram também a proteção da planta, dos animais e da saúde humana e as restrições a seis elementos potencialmente tóxicos: $\mathrm{Zn}, \mathrm{Cu}, \mathrm{Ni}, \mathrm{Cd}, \mathrm{Pb}$ e $\mathrm{Hg}$ (Hall, 1998).

No Brasil, os Estados do Paraná e São Paulo adaptaram respectivamente, as normas elaboradas pela Comunidade Européia e pelos E.U.A. para monitorar a aplicação de biossólidos em áreas agrícolas, devido principalmente, à falta de estudos locais para o estabelecimento de uma legislação própria. No Estado de São Paulo, teve início em 1996, a elaboração de uma norma técnica, com procedimentos e critérios para o uso de biossólidos em áreas agrícolas. Em 1999, a CETESB aprovou a Norma P4.230, contemplando os critérios para projetos de implantação e operação dos sistemas de aplicação de biossólidos das ETEs em solos agrícolas. Esta Norma foi elaborada com base na Legislação da Agência de Proteção Ambiental dos EUA (EPA parte 503), principalmente, e vem servindo de base para estudos do impacto ambiental em áreas agrícolas tratadas com biossólidos.

\subsection{Metais pesados e biossólidos}

A designação "metais pesados" é dada aos elementos com massa específica maior que $5 \mathrm{~g} \mathrm{~cm}^{-3}$. Metais pesados estão incluídos na categoria de "elementos traço", por serem naturalmente encontrados em concentrações de poucas partes por milhão (Mattiazzo-Prezotto, 1994). A origem primária dos metais pesados está relacionada ao material de origem do solo, já que a 
maioria das rochas contém estes metais em sua composição (Paul \& Clarck, 1996).

A absorção, distribuição e efeito de metais pesados em diferentes processos metabólicos são controlados por diferentes mecanismos, em plantas e microrganismos (Ross, 1994). Estes mecanismos irão atuar de acordo com cada organismo, seu estágio de desenvolvimento, tempo de exposição e disponibilidade do metal (Leita et al., 1995). Os metais pesados podem exercer funções importantes no metabolismo microbiano. Em altas concentrações, são tóxicos, podendo inibir atividades enzimáticas, alterar as funções das membranas e ocasionar danos ao DNA. (Roane, 1999).

Um dos problemas da utilização de biossólidos na agricultura é o enriquecimento do solo com metais pesados. O excesso de metais no solo pode causar efeitos prejudiciais às plantas (McGrathl., 1994) e inibir atividades microbianas essenciais (Brookes, 1995), com reflexos na ciclagem de nutrientes e fertilidade do solo (Giller et al., 1998). As concentrações máximas de metais pesados admitidos nos biossólidos a serem utilizados na agricultura, variam em função das legislações ambientais dos diferentes países (Quadro 1).

Os metais adicionados ao solo via biossólidos apresentam limitado movimento no perfil, acumulando-se geralmente nos horizontes superficiais (Chaney, 1994). Assim, altas doses ou repetidas apliçações, podem contribuir para o aumento da concentração de metais na camada arável. e conseqüentemente, nas plantas cultivadas (McGrath et al., 1995). Ao avaliar a disponibilidade de metais em três solos de texturas distintas (areia franca, franco argiloso e franco siltoso), tratados com diferentes doses de biossólidos (0, 42, 84, 126, 168 e $210 \mathrm{Mg} \mathrm{ha}^{-1}$, base seca), Rappaport et al. (1988) constataram que a aplicação de biossólido aumentou as concentrações de Cd, 


\begin{tabular}{|lcccccc|}
\hline Metal pesado & ${ }^{2}$ Suécia & ${ }^{b}$ Alemanha & ${ }^{a}$ Suíça & ${ }^{c}$ Holanda & ${ }^{d}$ França & ${ }^{e}$ EUA \\
Arsênio & - & - & - & - & - & 75 \\
\hline Cádmio & 15 & 10 & 30 & 10 & 20 & 85 \\
Cromo & 1000 & 900 & 1000 & 500 & 1000 & 3000 \\
Cobre & 3000 & 800 & 1000 & 600 & 1000 & 4300 \\
Chumbo & 300 & 900 & 1000 & 500 & 800 & 840 \\
Mercúrio & 8 & 8 & 10 & - & 10 & 57 \\
Molibdênio & - & - & - & - & - & 75 \\
Níquel & 500 & 200 & 200 & 100 & 200 & 420 \\
Selênio & - & - & - & - & 100 & 100 \\
Zinco & 10000 & 2500 & 3000 & 2000 & 3000 & 7500 \\
Prata & - & - & - & - & - & - \\
Cobalto & 50 & - & 100 & - & - & - \\
Manganês & - & - & 500 & - & - & - \\
\hline
\end{tabular}

(-) valor não determinado; ${ }^{\text {a }}$ Fernandes et al., 1993; ${ }^{\circ}$ Bergs \& Lindner, 1997; ${ }^{\circ}$ Silva, 1995; ${ }^{\circ} \mathrm{Nardin}$ \& Chabrier, $1997 ;{ }^{\circ}$ Estados Unidos, $1995 \mathrm{~b}$. Os dados são apresentados em $\left(\mathrm{mg} \mathrm{kg}^{-1}\right.$ de matéria seca).

Quadro 1. Teores máximos de metais pesados admitidos no biossólido a ser utilizado na agricultura, segundo a legislação de diversos países. 
$\mathrm{Cu}, \mathrm{Ni}$ e Zn nos grãos de milho e/ou nas folhas da base da espiga. Entretanto, tais concentrações encontravam-se dentro da faixa considerada adequada. Apesar das aplicações de $\mathrm{Zn}$ e $\mathrm{Cu}$ via biossólido excederem o limite estabelecido pela Agência de Proteção Ambiental dos Estados Unidos, não foram observodos sintomas de fitotoxicidade em milho, nos três solos estudados. A adição de biossólido promoveu um aumento da concentração de $\mathrm{Cd}, \mathrm{Cu}, \mathrm{Cr}$, Ni e Zn em Areia Quartzosa ou Latossolo Roxo, em doses variando de 13,5 a 40,5 $\mathrm{Mg} \mathrm{kg}^{-1}$ (base seca). Entretanto, o aumento da fitodisponibilidade desses metais para a cultura do milho (Zea mays L.) só foi observado para a maior dose aplicada (Oliveira, 1995).

Amostras de solo com diferentes pHs foram avaliadas por Kunito et al. (1999). Os efeitos do cobre sobre microrganismos foram avaliados pela relação entre a taxa de carbono da biomassa com o carbono total e a tolerância da comunidade à presença deste metal. Os resultados mostraram que outras propriedades dos solos exercem mais influência sobre a biomassa microbiana de carbono e a alta toxocidade do cobre foi modificada em função do pH. Em ensaios em casa-de-vegetação, Berton et al. (1989) estudaram as alterações nas propriedades químicas e disponibilidade de $\mathrm{N}, \mathrm{P}, \mathrm{K}, \mathrm{Ca}, \mathrm{Mg}, \mathrm{Zn}$ e Cu, em cinco solos representativos do Estado de São Paulo, após a incorporação do equivalente a 40 ou $80 \mathrm{Mg} \mathrm{ha}^{-1}$ de biossólido (base seca), usando milho como planta teste. Os resultados mostraram que a incorporação de biossólidos proporcionou a elevação do $\mathrm{pH}$ em todos os solos, reduzindo os teores de Altrocável. A adição de biossólido também aumentou o rendimento da mátéria seca das plantas e das quantidades de N, P, Ca, Mg e Zn absorvidas. Nem mesmo na dose mais alta de biossólido, a absorção de $\mathrm{Cu}$ e $\mathrm{Zn}$ pelas plantas chegou a atingir níveis que pudessem reduzir a produção de matéria seca da parte aérea do milho. 
Um estudo em microcosmo, comparando o efeito de espécies de plantas, origem do solo e um inoculante bacteriano no estabelecimento de comunidades microbianas que coloniząm as raízes das plantas foi conduzido por Miethling et al. (2000), os quais detectaram comunidades específicas em função da cultura utilizada, não havendo efeitos em relação ao tipo de solo. A presença de uma determinada cultura, em geral, proporciona o desenvolvimento de microsítios na rizosfera, resultantes da produção de exsudatos específicos a cada cultura (Baudoin et al., 2000). Às comunidade microbianas da rizosfera podem sofrer variações em função do estado fisiológico e estágio de desenvolvimento da planta (Gelsomino et al., 1999). Mudanças na estrutura da comunidade de Bacteria foram observadas por Kozdroj \& van Elsas (2001), demonstrando os efeitos de exsudatos de raízes.

Duas hipóteses têm sido propostas para descrever o efeito de metais potencialmente tóxicos em solos tratados com biossólidos nas plantas. A primeira hipótese é chamada "efeito platô". Segundo essa hipótese, o sistema solo-planta possuiria mecanismos específicos que tenderiam a estabelecer uma barreira à absorção de metais, os quais seriam absorvidos a uma taxa determinada e sua biodisponibilidade se manteria constante ou diminuiria com o tempo. A segunda hipótese é chamada "bomba relógio". Essa hipótese postula que a capacidade de adsorção do metal no solo aumenta com a adição de matéria orgânica. Durante a sua mineralização, esses metais seriam liberados na solução do solo, causando toxidez às plantas e microrganismos (Chang et al., 1997). A hipótese "platô" sugere que o biossólido é tanto uma fonte como um sumidouro para os metais pesados aplicados ao solo. De acordo com Logan et al. (1997), há fatores confusos na hipótese "platô", em relação à decomposição da matéria orgânica do biossólido e aos efeitos deste sobre o pH do solo. A hipótese "bomba relógio" também apresenta aspectos pouco conhecidos, sugerindo que o comportamento de metais em solos tratados com biossólidos deve ser mais estudado. 
Os efeitos de metais pesados sobre as populações microbianas dos solos foram investigados por vários autores. $\mathrm{O}$ impacto de metais pesados no crescimento de plantas e os efeitos sobre a atividade microbiana e fertilidade do solo, após um longo tempo de aplicação de biossólidos, foi avaliado medindo-se a atividade respiratória aeróbia e a biomassa microbiana. Estes parâmetros e a estimativa das populações de cianobactéria, Rhizobium e micorriza, foram afetados de forma adversa, mesmo em solos que receberam biossólidos com metais em concentrações abaixo dos limites estabelecidos pela Comunidade Européia.

Leita et al. (1995) estudaram a influência dos metais $\mathrm{Pb}, \mathrm{Zn}$ e TI na sobrevivência da biomassa microbiana. Os resultados mostraram que aumentos significativos nos valores de $\mathrm{qCO}_{2}$ foram observados nas amostras de solos contaminados com metais. Isso sugere que a biomassa utiliza amplamente seu potencial fisiológico para sobreviver em situações de estresse. Para isso, pode usar dois mecanismos, mobilização e posterior liberação do metal que se torna disponível em solução novamente. McGrath et al. (1995) usaram solos siltoso e arenoso para avaliar os efeito da aplicação de biossólidos, por períodos prolongados. Os resultados mostraram que vários parâmetros foram indicativos do impacto causado pelos metais em alta concentração. Da mesma forma, aumentos de até $76 \%$ na concentração de metais pesados em solos, diminuíram significativamente a atividade fixadora de nitrogênio de cianobactérias e o número de células de Rhizobium leguminosarum bv. trifolii, em relação ao controle não contaminado (Dahlin et al., 1997). Esses dados sugerem que a fixação biológica de nitrogênio pode ser utilizada como um indicador das condições de estresse do solo, pois é severamente afetada pela presença de metais pesados.

Algumas espécies de microrganismos são capazes de suportar concentrações relativamente altas de metais pesados. A tolerância de 
Pseudomonas marginalis e Bacillus megaterium, isolados de solos contaminados por $\mathrm{Pb}$, foi avaliada em alta e baixa concentração de $\mathrm{Pb}$. $\mathrm{A}$ análise por microscopia eletrônica de transmissão mostrou que um novo mecanismo de seqüestro intracelular do $\mathrm{Pb}$ é usado por $B$. mageterium. Já, $\mathrm{P}$ marginalis produz substâncias extracelulares como forma de proteção (Roane, 1999). Da mesma forma, os efeitos de $\mathrm{Pb}$ sobre microrganismos de três tipos de solos (residencial, industrial e agrícola) foram avaliados, utilizando-se perfis de fosfolipídios e ácidos nucléicos. Os dados sugerem que, em geral, as comunidades microbianas dos solos foram pouco afetadas pelo $\mathrm{Pb}$ (Konopka et al., 1999b).

Trabalhando com biossólido enriquecido com metais, em concentrações 4 vezes maiores do que a permitida pela União Européia, em doses que variaram de 40 a $160 \mathrm{Mg} \mathrm{ha}^{-1}$, Chander et al. (1995) encontraram incrementos de até 5,4 vezes na atividade microbiana, medida pela liberação de $\mathrm{CO}_{2}$, após 4 semanas de incubação, em solo com a dose mais elevada de biossólido. Após 64 semanas de incubação, os solos que haviam recebido as menores doses não apresentaram nenhum efeito adverso. No entanto, nos solos com doses mais elevadas de biossólidos foi observada redução na mineralização do nitrogênio orgânico. Os biossólidos enriquecidos com Zn foram mais tóxicos do que aqueles enriquecidos com $\mathrm{Ni}, \mathrm{Cu}$ e $\mathrm{Cd}$, na respectiva ordem: $\mathrm{Zn}>\mathrm{Ni}>\mathrm{Cu}>\mathrm{Cd}$ : Bååth et al. (1998), com o resultado da análise de componente principal dos padrões de ácidos graxos fosfolipídicos da comunidade microbiana do solo, mostraram que a aplicação de altas doses de $\mathrm{Cu}$ afeta a comunidade microbiana alterando sua estrutura, induzindo ou reduzindo do número de espécies, conforme o conteúdo de umidade do solo.

Os efeitos da contaminação de solo por metais pesados sobre a ciclagem de nutrientes, podem ser determinados por comparação da biomassa microbiana e atividades de mineralização. Kuperman \& Carreiro (1997), 
estudam uma área de pastagem contaminada com metais, através da determinação da biomassa microbiana, atividades enzimaticas ( $N$ acetilglucosaminidase, $\beta$-glucosidase, endocelulase e fosfatase alcalina) e respiração induzida por substrato, verificaram que a contaminação por metais afeta de modo adverso a abundância e atividade de microrganismos envolvidos na decomposição e ciclagem de nutrientes. Khan \& Scullion (1999) estudando cinco solos com diferentes conteúdos de argila, matéria orgânica e pH. Encontraram variações significativas nos diferentes parâmetros microbiológicos (biomassa microbiana, conteúdo de ergosterol, $\mathrm{qCO}_{2}$, conteúdo de $\mathrm{N}$, ácidos graxos fosfolipídicos, etc), demonstrando os efeitos de altas concentrações de metais pesados sobre a microbiota de solos com diferente textura.

Fließbach et al. (1994) avaliaram o carbono da biomassa microbiana (C-biomassa) e a respiração de solo, após um longo tempo da aplicação de biossólido contendo alta e baixa concentração de metais pesados. A aplicação de biossólido com baixa concentração de metais resultou em aumento na Cbiomassa e atividade microbiana do solo. Por outro lado, com a aplicação de biossólido com alta concentração de metais, houve um decréscimo substancial no C-biomassa. O quociente metabólico $\left(\mathrm{qCO}_{2}\right)$, ou seja, a respiração do solo por unidade de biomassa, aumentou com a quantidade de metais pesados aplicados, sugerindo que o $\mathrm{qCO}_{2}$ é um indicador sensível de estresse causado por metais pesados em solos. Contudo, a matéria orgânica pode mascarar um possível efeito inibitório de espécies químicas tóxicas presentes em biossólidos sobre a microbiota. O maior estímulo do crescimento das populações microbianas na presença de matéria orgânica em relação ao efeito inibitório de metais pode ser freqüentemente observado em solos que receberam biossólidos (Lambais, dados não publicados). Assim, as análises de atividades das comunidades microbianas podem trazer grande contribuição para a geração de índices de qualidade biológica de solos, compatíveis com as 
necessidades de controle e monitoramento da aplicação agrícola de biossólidos.

\subsection{Efeito de biossólidos e metais na diversidade funcional dos solos}

Nos solos existe um número elevado de bactérias, fungos, algas, e outros organismos (Tsai et al., 1992). Uma grande variedade de grupos bacterianos pode participar dos diversos processos biogeoquímicos (Alexander, 1977). Em solos colonizados por plantas, podemos encontrar, por exemplo, bactérias promotoras do crescimento (Pseudomonas, Azotobacter, Azospirillum, Beijerinckia), fixadoras de nitrogênio (Azotobacter, Beijerinckia, Azospirillum, Bacillus, Rhizobium e Bradyrhizobium, dentre outras), e bactérias que participam dos processos de degradação da matéria orgânica presentes na região da rizosfera ou fora dela (Liesack et al., 1997; Dalmastri et al., 1999). Na rizosfera, são liberados os exudatos de plantas que servem como fonte de nutrientes para comunidades microbianas específicas. Por outro lado, as atividades metabólicas destes microrganismos, resultam na liberação de substâncias orgânicas que podem afetar o desenvolvimento das plantas . Os microrganismos da rizosfera também interagem entre si, resultando em relações complexas, ainda pouco compreendidas (Ross, 1984).

A diversidade funcional da microbiota do solo esta relacionada com a capacidade dos microrganismos participarem nos ciclos biogeoquímicos, decomposição de moléculas orgânicas e outras transformações (Zak et al., 1994), possibilitando o uso de comunidades bacterianas como indicadores de distúrbios ambientais. As atividades antrópicas têm promovido alterações nas condições do meio ambiente, comprometendo a diversidade de espécies, principalmente devido à destruição ou redução dos recursos tróficos (Giller, 1984). A competição, mutualismo e outras relações tróficas nestas condições induz, freqüentemente, interações secundárias entre espécies, com efeitos 
deletérios para o ecossistema. A diversidade funcional das comunidades microbianas nos solos tem efeito direto na estrutura das mesmas, e vice-versa, demonstrando a natureza complexa das interrelações biológicas nestes ecossistemas (Chapin III et al., 2000). Tem sido sugerido que a sustentabilidade dos solos agrícolas depende da manutenção de comunidades microbianas ativas, com alta diversidade genética e funcional (Kennedy \& Smith, 1995).

Alterações nas propriedades e atividades microbianas dos solos em situações de estresse vêm sendo constatadas, através da utilização de métodos gerais de enumeração e quantificação da biomassa e avaliação das atividades bioquímicas (Alexander, 1977). Em geral, esses métodos utilizam o cultivo dos microrganismos do solo. No entanto, estima-se que mais de $90 \%$ dos microrganismos presentes no solo não posșam ser cultivados em meios de cultura (Torsvik et al., 1995). A presença de organismos não-cultiváveis no solo torna as técnicas convencionais limitadas (Øvreås et al., 1997), impedindo uma caracterização precisa do ecossistema (Torsvik et al., 1998).

Banerjee et al. (1997) estudaram a variação na biomassa e diversidade funcional das populações microbianas de um solo que recebeu a aplicação de biossólidos. Os resultados obtidos sugerem que embora a população microbiana tenha sua diversidade reduzida, apresenta biomassa igual ou superior aos controles sem biossólidos: Quando altas concentrações de biossólidos (200 Mg ha-1) são aplicadas, reduções da diversidade funcional das comunidades microbianas são observadas. Porém, a biomasa microbiana e a taxa de mineralização de N, P e S não são afetadas.

A diminuição na diversidade genética de microrganismos pode reduzir a diversidade funcional, e, consequentemente, a ciclagem de alguns nutrientes (Altieri, 1999). Os processos de mineralização de C- e N-orgânico são altamente redundantes, ou seja, diferentes populações de microrganismos 
podem, em diferentes condições ambientais, realizar estes processos. Quando estas populações são afetadas por condições de estresse, os efeitos gerais sobre a mineralização de C e $\mathrm{N}$ são desprezíveis (McCann, 2000). Assim, atividades que apresentam alto grau de redundância dificilmente se correlacionam com as alterações da qualidade do solo, embcra sejam importantes na determinação de taxas de degradação de materiais orgânicos, como os biossólidos (Beare et al., 1995). As atividades bioquímicas raras, de menor redundância, podem ser indicadores potenciais da qualidade dos ecossistemas (Bending et al., 2000). Mudanças nessas atividades podem induzir distúrbios funcionais mensuráveis no solo, como a diminuição da fertilidade e capacidade de degradação de moléculas potencialmente poluentes (Altieri, 1999). O impacto de biossólidos contaminados com metais pesados na microbiota dos solos pode ser extremamente elevado, reduzindo a competência fisiológica da comunidade microbiana. Alterações na funcionalidade da comunidade microbiana, com base na capacidade de utilização de diferentes fontes de carbono, têm sido úteis para diagnosticar situações de estresse (Zak et al., 1994; Kostov et al., 2001). Reber (1992) avaliou a capacidade degradativa de bactérias de solo, com base na utilização de diferentes fontes de carbono, utilizando placas BIOLOG. Os resultados demonstram que a capacidade de utilização de substratos aromáticos pela comunidade microbiana foi significativamente reduzida em solos contaminados com metais pesados. Este autor concluiu que o impacto de biossólidos contaminados com metais pesados é extremamente elevado, podendo reduzir a competência fisiológica da comunidade microbiana, com conseqüentes efeitos negativos na ciclagem de nutrientes e degradação de xenobióticos.

As placas de BIOLOG foram inoculadas para avaliar a capacidade de utilização das fontes de carbono (dextrina, celobiose, D-frutose, D-rafinose, ácido cítrico, D-galactose, L-asparagina e outras), na rizosfera de batata. Após 48 horas de incubação das placas, o DNA total foi extraido, amplificado e 
separado em TGGE/DGGE. Os resultados não refletiram necessariamente o potencial funcional dos membros dominantes detectados pela redução no número de fragmentos de rRNA 165 em várias posições da placa. Os fragmentos dominantes no gel estão relacionados à subdivisão gama da classe de Proteobacterias, sugerindo que bactérias de rápido crescimento adaptadas à alta concentração de substrato são numericamente dominantes e responsáveis pelo padrão de consumo, compatível com a rizosfera de batata. Este estudo mostrou que o perfil de utilização de fonte de carbono não reflete necessariamente $o$ potencial funcional dos membros numericamente dominantes na comunidade microbiana usada como inóculo, já que essa técnica baseia-se no cultivo de microrganismos. (Smalla et al., 1998).

Brim et al. (1999) estudaram a comunidade bacteriana de um solo contaminado com $\mathrm{Zn}$ por técnicas de cultivo e por análise dos perfis de metil esteres de ácidos graxos (FAME). Os resultados sugerem que a adição contínua de metais em ambientes naturais pode ocasionar alterações na abundância relativa de espécies tolerantes a metais, resultando em perda de diversidade genética e metabólica. As análises das seqüências de nucleotídios do rDNA 165 de bactérias desse solo revelaram a presença dos grupos $\alpha$ - e $\beta$ de proteobacteria e Cytophaga-Flexibacter-Bacteroides. Pela análise de FAME, uma estirpe resistente a metais, Ralstonia eutropha, foi encontrada como biotipo dominante.

\subsection{Efeito de biossólidos e metais pesados na diversidade genética e estrutura de comunidades microbianas}

Comunidade é o agrupamento de populações de diferentes espécies, com capacidade de sobrevivência e sustentação própria, localizado em uma determinada região geográfica ou bióma (Kuske et al., 1997; Krebs, 1989). A estrutura da comunidade é dada por suas características ou padrões de 
organização das espécies, em termos da diversidade, abundância relativa, dominância, distribuição espacial e temporal, diversidade de tipos reprodutivos e distribuição dos recursos tróficos (Giller, 1984).

Estima-se que somente uma pequena parcela (13\%) da população microbiana mundial já está identificada. Como conseqüência, uma grande parcela da biota ainda permanece desconhecida e, portanto, não é estudada (Torsvik et al., 1995). A componente biológica na produtividade de solos agrícolas tem sido ignorada, mas é um aspecto importante no funcionamento do ecossistema. Além disso, a microbiota do solo é altamente sensível aos distúrbios causados pelas atividades antrópicas (Kandeler et al., 1996). Mudanças nas propriedades químicas e físicas dos solos, resultantes das práticas de manejo, alteram as características quantitativas e qualitativas dos microsítios, e consequentemente, o crescimento das populações microbianas. Adicionalmente, mudanças significativas na composição da comunidade ao longo do perfil podem ocorrer, influenciando o desenvolvimento do sistema radicular das plantas e as simbioses (Shen, 1997).

Ecologistas têm buscado, nos últimos 20 anos, a melhor forma para estimar a diversidade em amostras ambientais. Os índices de similaridade probabilística têm sido relevantes na classificação ecológica, possibilitando a determinação da ocorrência ou abundância de uma espécie numa amostra ou padrão, em função da sua probabilidade de distribuição na amostra analisada (Jørgensen, 1992). Muitos métodos têm sido empregados para estimar a diversidade de microrganismos. A utilização desses índices permite a avaliação da estrutura de comunidades e comparações entre comunidades, independentemente da forma de amostragem e do tamanho da amostra (Giller, 1984).

A estrutura de comunidades pode ser avaliada pela determinação da diversidade de espécies presentes nestas comunidades. A diversidade é função 
de dois componentes principais: a) número total de espécies presentes (riqueza de espécies ou abundância de espécies); b) distribuição dos indivíduos entre as espécies (eqüitabilidade de espécies) (Kennedy, 1999). Porém, um índice de diversidade não é um valor único, e pode não indicar a composição total da comunidade. Assim, os dados devem ser interpretados considerando-se tanto a riqueza quanto a eqüitabilidade de espécies. Os índices de diversidade de espécies usados para plantas e animais devem ser utilizados com cautela no estudo de comunidades microbianas devido, principalmente, à dificuldade de definição de espécie nesse grupo de organismos (Watve \& Gangal, 1996). Assim, muitos estudos têm sido realizados considerando características fenotípicas e/ou genotípicas de isolados bacterianos.

A toxicidade exercida por metais pesados pode suprimir ou muitas vezes eliminar os organismos sensíveis da comunidade microbiana, resultando numa mudança na estrutura da comunidade (Fließ $\beta$ bach et al., 1994). Frostegård et al. (1993b) determinaram os efeitos de cinco metais na biomassa microbiana, atividade e estrutura da comunidade, em dois tipos de solos por um período de seis meses. Mudanças graduais na estrutura da comunidade foram observadas, pela determinação de alterações nos padrões de ácidos graxos de fosfolipídios. Os dados sugerem que houve seleção de populações tolerantes a metais.

A sobrevivência de cinco espécies de bactérias com e sem a adição de metais pesados ( $\mathrm{Cs}, \mathrm{Cd}, \mathrm{Co}, \mathrm{Sr}$ ) foi avaliada através de PCR-DGGE. Os amplicons obtidos refletem a abundância relativa de bactérias em dois microcosmos: culturas puras e espécies de eubactérias, que permanecem no solo após a inoculação. Três espécies: Pseudomonas aeruginosa FRD-1, Shewanella putrefaciens 200, Desulfovibrio vulgaris Hildenborough, a abundâncias relativas decresceu logo após a inoculação. A abundância de Alcaligenes eutrophus $\mathrm{CH} 34$ permaneceu constante nas 8 semanas de incubação, em ambos os tratamentos. Já a abundância de Sphingomonas 
aromaticivorans B0695 foi dose-dependente, diminuindo rapidamente em solo não-contaminado. Stephen et al. (1999) mostrou que em um microcosmo nativo, antes da inoculação de adição dos metais, representado as espécies mais abundantes. Estas amostras diferem das outras pela presença de amplicons em número e posições diferentes. Desses amplicons, um foi isolado e seu DNA clonado e seqüenciado. A seqüência de nucleotídeos revelou $100 \%$ de homologia com uma $\alpha$-proteobactéria não identificada, muito semelhante a Caulobacter subvibroides, Rhizomonas suberifacians e Sphingomonas sp. Este amplicom está presente em todos os tratamentos; ao longo do estudo, sugerindo tratar-se de espécie tolerante a metais pesadós.

Borneman et al. (1996) estudaram a diversidade microbiana de solo sob pastagem, grande variedade de espécies vègetais, através da caracterização de clones do rDNA 16S. Dos 124 clones seqüenciados, 98,4\% eram de Bacteria, duas seqüências derivadas de organelas de procariotos (fungo e planta), nenhuma seqüência de Archaea foi encontrada. Os representantes de Bacteria, estavam distribuídos da seguinte forma: 16,1\% $(\alpha, \beta, \delta)$-Proteobacteria, $21,8 \%$ grupo dos Cytophaga-Flexibacter-Bacteroides, $21,8 \%$ grupo de gram-positivas com baixo conteúdo de $G+C, 39,4 \%$ de outros grupos desconhecidos. Essa metodologia possibilitou o estudo da diversidade microbiana sem o emprego de técnicas de cultivo. Os estudos conduzidos por Sandaa et al. (1999) avaliaram o impacto da contaminação de metais pesados na comunidade de Archaea em solos que receberam diferentes doses de biossólidos. A hibridização in situ utilizando sondas fluorescentes (FISH) mostrou um decréscimo na percentagem de Archaea, 1,3-0,3\% de 4',6-diamino2-phenilidona, em solos não tratados com biossólidos para valores abaixo do limite de detecção, em solos tratados com biossólidos contaminados com metais pesados. A análise do rDNA $16 S$ por DGGE revelou alteração na estrutura da comunidade de Archaea em função da contaminação por metais pesados. Os clones de rRNA 165 mostraram alta similaridade com um único 
organismo, largamente distribuído, do reino das Crenarchaeota que é filogenéticamente diferente das espécies caracterizadas.

Macnaughton et al. (1999) avaliaram a comunidade de procariotos em um solo, após a aplicação de uma mistura de sais de metais pesados, por PCR-DGGE e análise de ácidos graxos de fosfolipídios. A adição de metais tóxicos ( $\mathrm{Sr}, \mathrm{Co}, \mathrm{Cs}, \mathrm{Sr}$ ) resultou numa rápida alteração (1 semana) da comunidade de eubactérias, quando comparado com o controle sem adição de metais. Estas alterações permaneceram ao longo de todo o experimento (8 semanas). As maiores mudanças observadas em microcosmos contaminados, em relação aos controles, foram, o aparecimento de quatro novos biotipos (amplicons). Dois gêneros foram indentificados por seqüenciamento $e$ apresentaram $100 \%$ de homologia com Acinetobacter e Burkholderia, mostrando uma vantagem seletiva sobre outras eubacterias indigenas indizidas por estresse com metal.

Eichner et al. (1999) analisaram o rDNA 16S, usando TGGE, da comunidade microbiana de lodos ativados, após exposição a dois fenóis substitu ídos. Os sistemas de produção de lodo foram inoculados com: (i) microrganismos genéticamente modificados (MGM) para degradação de fenóis substituídos, (ii) estirpes parentais não modificadas geneticamente. Para análise quantitativa dos amplicons por TGGE, as bandas foram normalizadas por um padrão externo. As amostras foram então comparadas por similaridade usando o coeficiente de Dice. $O$ índice de diversidade de Shannon-Weaver $(H)$ foi calculado para cada tratamento. Os resultados demonstram a diminuição na diversidade das comunidades após o tratamento do lodo ativado com fenol. No sistema não-inoculado, o valor de $H$ diminuiu de 1,13 para 0,22 , já, no sistema inoculado, o H dimimuiu de 1,03 para 0,82. Nas amostras onde a inoculação foi feita com as estirpes parentais, o índice de Shannon-Weaver diminuiu de 1,22 para 0,46, após o tratamento com 3-clorofenol-4-metilfenol, e de 1,03 para 0,70, 
após o tratamento com 4-clorofenol-4-metilfenol. A capacidade catabólica dos MGMs permitiu a proteção da comunidade microbiana do lodo ativado.

\subsection{Técnicas moleculares para o estudo de comunidades microbianas dos solos}

O isolamento e identificação dos microrganismos são a primeira etapa no estudo de comunidades microbianas no solo. Como à maioria das populações bacterianas não são de fácil cultivo, a identificação destes organismos por via bioquímica é insuficiente para um adequado monitoramento ambiental (Schneegurt \& Kulpa, 1998).

A introdução de técnicas moleculares na análise da diversidade de comunidades microbianas foi um dos principais avanços da ecologia microbiana (Rosado et al., 1997). Para informações da presença e diversidade de grupos funcionais importantes e detecção de relações filogenéticas entre os microrganismos, têm-se utilizado as características dos genes codificando, o rRNA $16 S$ de procariotos ou $18 \mathrm{~S}$ de eucariotos (Amann et al., 1995). Outros métodos têm sido desenvolvidos para detectar e quantificar grupos filogenéticos, com base nas seqüências de genes específicos. Algumas destas técnicas são baseadas em hibridização DNA-DNA, outras na amplificação por PCR do DNA da comunidade microbiana seguido de análise de restrição (Liesack et al., 1997). Transcrição reversa pode ser associada a PCR para avaliar, também, a expressão de genes específicos. As vantagens e desvantagens de cada método podem ser vistas no Quadro 2.

A extração e análise de ácidos nucléicos, DNA ou RNA, de amostras ambientais, como solo, água e sedimentos, são fundamentais para qualquer procedimento experimental (Trevors \& van Elsas, 1995). As metodologias para extração de DNA consistem das seguintes etapas: (a) lise da célula ou 


\begin{tabular}{|c|c|c|}
\hline MÉTODO & VANTAGENS & DESVANTAGENS \\
\hline $\begin{array}{l}\text { Contagem em placa } \\
\text { (Brim et al., 1999) } \\
\text { Utilização de substratos } \\
\text { de C (BIOLOG) } \\
\text { (Bending et al., 2000) }\end{array}$ & $\begin{array}{l}\text {-Procedimento rápido } \\
\text {-Baixo custo } \\
\text {-Espécies isoladas } \\
\text {-Procedimento rápido } \\
\text {-Baixo custo } \\
\text { - Comunidade microbiana }\end{array}$ & $\begin{array}{l}\text {-Muitas espécies não são } \\
\text { cultiváveis; } \\
\text {-Informações limitadas. } \\
\text {-Placas não são } \\
\text { desenhadas para análises } \\
\text { de solo. }\end{array}$ \\
\hline $\begin{array}{l}\text { FAME (metil éster de } \\
\text { ácidos graxos) de solo } \\
\text { (Miethling et al., 2000) } \\
\text { PFLA ácidos graxos de } \\
\text { fosfolipídios totais } \\
\text { (Yao et al., 2000) }\end{array}$ & $\begin{array}{l}\text {-Procedimento rápido; } \\
\text {-Perfil lipídico da comunidade; } \\
\text { - Identificação de marcadores. } \\
\text {-Perfil da comunidade microbiana viva; } \\
\text { - Identificação de marcadores; } \\
\text { - Indicador da biomassa. }\end{array}$ & $\begin{array}{l}\text {-Detecta microrganismos } \\
\text { vivos e mortos; } \\
\text {-Detecta plantas e ácidos } \\
\text { húmicos. } \\
\text {-Procedimento demorado; } \\
\text {-Utiliza-se geralmente de } \\
\text { produtos químicos tóxicos. }\end{array}$ \\
\hline $\begin{array}{l}\text { PCR (reação em cadeia } \\
\text { de polimerase) (Nübel et } \\
\text { al., 1999) }\end{array}$ & $\begin{array}{l}\text { - Amplificação seletiva de fragmentos } \\
\text { do gene } 16 S \text { rRNA de comunidades } \\
\text { mistas; } \\
\text {-Procedimento rápido. }\end{array}$ & $\begin{array}{l}\text {-Produção de produtos } \\
\text { quiméricos; } \\
\text {-Pode ocorrer amplificação } \\
\text { preferencial }\end{array}$ \\
\hline $\begin{array}{l}\text { RT(transcrição reversa) } \\
\text { (Kowalchuk et al., 1999) }\end{array}$ & $\begin{array}{l}\text { - Técnica mais rigorosa de extração de } \\
\text { ácido nucléico deve ser aplicada; } \\
\text {-Recuperação seletiva de informações } \\
\text { de seqüências de rRNA. }\end{array}$ & \\
\hline $\begin{array}{l}\text { SSCP (polimorfismo de } \\
\text { conformação de fita } \\
\text { simples) } \\
\text { (Schwieger \& Tebbe, } \\
\text { 1998) }\end{array}$ & $\begin{array}{l}\text {-Não envolve clonagem } \\
\text { - Mede a diversidade da comunidade } \\
\text { de bactéria; } \\
\text {-Sensível às populações marcadoras } \\
\text { em <1,5\%; } \\
\text { - Mudanças espaciais e temporais na } \\
\text { estrutura da comunidade podem ser } \\
\text { detectadas. }\end{array}$ & $\begin{array}{l}\text {-Afetado por: } \\
\text { •matriz do gel } \\
\text {-temperatura } \\
\text { •tamanho do fragmento } \\
\text {-seqüências utilizadas. }\end{array}$ \\
\hline $\begin{array}{l}\text { DGGETGGE (gel de } \\
\text { poliacrilamida com } \\
\text { gradiente desnaturante) } \\
\text { (Kozdrój \& van Elsas, } \\
\text { 2000) }\end{array}$ & $\begin{array}{l}\text {-Rápida avaliação da distribuição de } \\
\text { tipos de seqüências amplificáveis; } \\
\text {-Permite a separação de protutos de } \\
\text { PCR de diferentes organismos e de } \\
\text { misturas complexas. }\end{array}$ & $\begin{array}{l}\text {-Não detecta todas as } \\
\text { populações; } \\
\text {-Dados de seqüência } \\
\text { limitados; } \\
\text {-Reduzida separação de } \\
\text { fragmentos maiores que } \\
500 \text { pb. }\end{array}$ \\
\hline
\end{tabular}

Quadro 2. Vantagens e desvantagens dos métodos de análises microbiológicas de solos. 
recuperação e lise subseqüente; (b) extração e purificação dos ácidos nucléicos (Torsvik et al., 1995). O DNA obtido consiste de uma mistura de moléculas que, teoricamente, representam a biota presente na amostra. A qualidade e quantidade do DNA ambiental podem, assim, ser avaliadas em gel de agarose por comparação com padrão conhecido, e/ou espectrofotometria (Sambrook et al., 1989). Muitos métodos utilizam o DNA para análises de amostras ambientais, mas a extração e análise do RNA são, da mesma forma, importantes, pois estas moléculas estão relacionadas à atividade microbiana nas amostras. O rRNA pode ser usado para se obter informações das taxas de crescimento e diversidade de organismos ou populações microbianas. Enquanto, a análise de mRNA permite estudos da expressão de genes específicos no ambiente (Tsai et al., 1991).

Em amostras provenientes do solo, a presença de material húmico pode ser uma das maiores limitações, principalmente, para o emprego de técnicas de amplificação por PCR. Além disso, as substâncias húmicas podem reduzir a eficiência dos processos de clonagem molecular (Schuler \& Zielinski, 1989). Vários métodos podem ser usados para o estudo de amostras complexas, utilizando o material genético (DNA ou RNA) de amostras ambientais. As técnicas de hibridização permitem a detecção de genes específicos em um genoma complexo, ou de mRNAs específicos em transcritomas complexos. A hibridização de DNA-RNA tem sido usada para quantificar 0 gene mer em comunidades expostas a mercúrio, e genes envolvidos na degradação de compostos aromáticos por exemplo (Schneegurt \& Kulpa, 1998).

A amplificação de fragmentos do rDNA 165 de Bacteria, utilizando iniciadores homólogos a regiões conservadas do gene, aliado à eletroforese em gel de poliacrilamida com gradiente desnaturante (DGGE), tem sido útil na caracterização de alterações na estrutura de comunidades microbianas (Muyzer 
et al., 1993). Regiões conservadas do rDNA $16 S$ são alvos para iniciadores universais que podem amplificar o gene inteiro ou seqüências parciais de um grande número de organismos. A utilização de fragmentos amplificados (amplicons) longos permite que se obtenha a máxima quantidade de informação de seqüências para análise filogenética e de diversidade (Rochelle et al., 1995). A técnica de DGGE foi originalmente desenvolvida e aplicada em pesquisas médicas para detecção de mutação de ponto (Myers et al., 1987), e foi recentemente introduzida em estudos de ecologia microbiana (Muyzer at al., 1993). Amplicons de mesmo tamanho, mas de diferentes seqüências (regiões hipervariáveis do rDNA 16S, por exemplo), podem ser separados por eletroforese, de acordo com suas propriedades de desnaturação (Heurer \& Smalla, 1997).

A técnica de DGGE apresenta melhor resolução para pequenos fragmentos, neste caso, porém, nem todas as seqüências de bactérias conhecidas são amplificadas, mesmo quando a estringência é aumentada, para maior eficiência de amplificação e redução da formação de quimeras. Deve-se tomar cuidado, entretanto, na interpretação dos resultados. Pequenas contaminações podem levar a resultados imprecisos pela amplificação de falsos positivos (Sandaa et al., 1999). Além disso, pode haver seqüências muito semelhantes que apresentam a mesma mobilidade em géis com gradiente desnaturante (Kowalchuk et al., 1997).

Em geral, estudos de comunidades específicas (oxidantes de amônia, actinomicetos, Rhizobium, etc.), por DGGE, aliado a outras metodologias, como plaqueamento ou BIOLOG, permitem obter resultados mais precisos das alterações destas comunidades em relação aos distúrbios ambientais causados por diversas condições ambientais. A principal limitação metodológica atual refere-se à definição dos critérios de amostragem, definição de número de seqüências a serem analisadas e padronização de protocolos de 
extração de DNA. De um modo geral, os procedimentos experimentais devem evitar a extração e amplificação preferencial de DNA de grupos específicos, e formação de artefatos nas reações de amplificação por PCR, que podem resultar em falsos positivos. Estas limitações metodológicas devem ser consideradas nos estudos das alterações que ocorrem em ambientes naturais. 


\section{MATERIAL E MÉTODOS}

\subsection{Experimento 1: Alterações da estrutura da comunidade de Bacteria de um solo argiloso não-cultivado tratado com biossólido da ETE-Franca}

\subsubsection{Solo}

Foi usada amostra da camada superficial (0-20) de um solo, não cultivado, classificado como NITOSSOLO VERMELHO Eutroférrico típico, segundo o Sistema Brasileiro de Classificação de Solos (Embrapa, 1999), doravante designado argiloso, coletado no Campus da Escola Superior de Agricultura "Luiz de Queiroz" (ESALQ), Piracicaba, Estado de São Paulo. Análises químicas e físicas de uma subamostra do solo foram realizadas no Departamento de Solos e Nutrição de Plantas, ESALQ, conforme descrito por Raij et al. (1996) e Camargo et al. (1986), respectivamente. O P foi determinados por espectrofotometria, após extração com resina de troca de íons. Ca e Mn foram determinados por espectrofotometria de absorção atômica e $\mathrm{K}$ e $\mathrm{Na}$ foram determinados por fotometria de chama, após extração com resina de troca de cátions. $\mathrm{OH}+\mathrm{Al}$ foi determinado por titulometria, após extração com acetato de cálcio $0,5 \mathrm{~mol} \mathrm{~L}^{-1}(\mathrm{pH} 7,0)$. A análise granulométrica foi feita pelo método do densímetro (Camargo et al, 1986). 


\subsubsection{Biossólido}

O biossólido proveniente da ETE-Franca foi coletado em baldes plástico. A amostragem foi feita em 10 pontos aleatórios nas pilhas de biossólido localizadas no pátio da ETE-Franca, sendo armazenado a $4^{\circ} \mathrm{C}$ até o momento das análises químicas e instalação do experimento.

Uma subamostra do biossólido recém coletado foi enviada para análise no Laboratório de Análise de Solos, da ESALQ, conforme descrito por Eaton et al. (1985). O pH foi medido por potenciometria, em solução aquosa na proporção 1:1. A quantidade de água foi determinada gravimetricamente, pela umidade perdida a $65^{\circ} \mathrm{C}$. O C-orgânico foi determinado por digestão com $\mathrm{K}_{2} \mathrm{Cr}_{2} \mathrm{O}_{7}$ e $\mathrm{H}_{2} \mathrm{SO}_{4}$ e titulação com $\mathrm{FeSO}_{4} 1 \mathrm{~mol} \mathrm{~L}^{-1}$. O N-total foi determinado por digestão com $\mathrm{H}_{2} \mathrm{SO}_{4}$, destilação em meio alcalino e titulação com $\mathrm{H}_{2} \mathrm{SO}_{4} 0,025$ $\mathrm{mol} \mathrm{L}^{-1}$. Os teores de $\mathrm{P}, \mathrm{K}, \mathrm{Ca}, \mathrm{Mg}$ e Fe foram determinados em extrato obtido por incineração da amostra a $550^{\circ} \mathrm{C}$ dissolvendo-se as cinzas com solução de $\mathrm{HCl}$. À extração com resína de troca foi utilizada para extração e subseqüente análises de: P-total, por espectrofotometria pelo método do amarelo de molibdênio; K-total e Na-total, por titulometria com EDTA 0,01 $\mathrm{mol} \mathrm{L}^{-1}$; S-total, por gravimetria, após precipitação com $\mathrm{BaCl}_{2}$; Cu-total, Mn-total, Zn-total e Fetotal foram determinados por espectrofotometria de absorção atômica. As determinações das concentrações de $\mathrm{Ni}, \mathrm{Cr}, \mathrm{Cd}$ e $\mathrm{Cu}$ foram feitas no laboratório de Química Ambiental do Departamento de Ciências Exatas da ESALQ/USP por espectrofotometria de absorção atômica em extrato de digestão nitroperclórica. 


\subsubsection{Delineamento experimental}

O delineamento experimental utilizado foi inteiramente casualizado, com 4 doses de biossólido da ETE-Franca (18,6; 37;2; 74,4; 148,8 $\mathrm{g} \mathrm{kg}^{-1}$ ) e um controle sem adição de biossólido, em 4 repetições. A unidade experimental foi constituída por vasos de $1,5 \mathrm{~L} \mathrm{com} 0,5 \mathrm{~kg}$ de solo.

\subsubsection{Instalação e condução do experimento}

As doses de biossólido foram definidas de acordo com a Norma da CETESB P4.230 (São Paulo, 1999), em função da quantidade de nitrogênio mineralizável, adotando-se uma taxa de mineralização de $20 \%$, valor recomendado para biossólidos estabilizados por digestão anaeróbia e das necessidades de uma cultura de milho para obtenção de uma produtividade considerada média-alta. As doses foram calculadas a partir da dose equivalente ao fornecimento de $150 \mathrm{~kg} \mathrm{~N} \mathrm{ha}^{-1}$ (Raij et al., 1996). As outras doses foram:

Dose 1 - controle sem aplicação de biossólido

Dose 2 - 18,6 $\mathrm{g} \mathrm{kg}^{-1}$ ou $6 \mathrm{Mg} \mathrm{ha}^{-1}$ (metade da dose 3:)

Dose 3 - 37, $2 \mathrm{~g} \mathrm{~kg}^{-1}$ ou $12 \mathrm{Mg} \mathrm{ha}^{-1}$ (150 kg N ha-1)

Dose 4 - 74,4 $\mathrm{g} \mathrm{kg}^{-1}$ ou $24 \mathrm{Mg} \mathrm{ha}^{-1}$ (2 vezes a dose 3)

Dose 5 - 148,8 $\mathrm{g} \mathrm{kg}^{-1}$ ou $48 \mathrm{Mg} \mathrm{ha}^{-1}$ (4 vezes a dose 3 ).

O experimento foi realizado em condições de casa-de-vegetação nas dependências do Departamento de Solos e Nutrição de Plantas, da ESALQ, no período de Setembro a Novembro de 2000. Foram feitas amostragens após 1, 2, 4 e 8 semanas de incubação, totalizando 20 parcelas por época. Em cada vaso, o solo foi homogeneizado e uma subamostra $(100 \mathrm{~g})$ foi retirada e armazenada em sacos plásticos devidamente identificados. De cada tratamento, obteve-se uma amostra composta a partir de 4 subamostras, que foram utilizadas para extração de DNA total. 
3.2 Experimento 2: Alterações da diversidade genética e estrutura das comunidades de Bacteria em solos cultivados com milho (Zea mays), após a aplicação de biossólidos.

\subsubsection{Solos}

Foram utilizadas amostras de dois solos classificados como: NITOSSOLO VERMELHO Eutroférrico típico e NEOSSOLO QUARTZARÊNICO Órtico típico, de acordo com o Sistema Brasileiro de Classificação de solos (Embrapa, 1999), doravante designados argiloso e arenoso, respectivamente, coletados na região de Piracicaba. Análises químicas e físicas de uma subamostra de cada solo foram realizadas no Departamento de Solos e Nutrição de Plantas, ESALQ, conforme descrito por Raij et al. (1996) e Camargo et al. (1986).

\subsubsection{Biossólidos}

Foram utilizados biossólidos da ETE-Franca (baixa concentração de metais) e da ETE-Barueri (alta concentração de metais). Os procedimentos de coleta, amostragem e análises foram realizados conforme descrito no ítem 3.1.2.

\subsubsection{Delineamento experimental}

O delineamento experimental utilizado foi inteiramente casalizado em esquema fatorial, constituído de três doses de biossólidos, duas épocas de coleta (30 e 60 dias após o plantio de milho), dois tipos de solo (argiloso e arenoso), em 3 repetições. Foram usadas quantidades equivalentes a 6; 24; 96 $\mathrm{Mg} \mathrm{ha}^{-1}$ do biossólido da ETE-Franca e quantidades equivalentes a 31; 62; 124; $\mathrm{Mg} \mathrm{ha}^{-1}$ do biossólido da ETE-Barueri. 
além de um controle sem adição de biossólido, para cada tipo de solo. A unidade experimental foi constituída por vasos com $3 \mathrm{~kg}$ de solo, contendo 4 sementes de milho (Dina 766, Dina milho, SP).

\subsubsection{Instalação e condução do experimento}

A calagem dos solos foi realizada com calcário dolomítico (PRNT $130 \%$ ) para elevar a saturação em bases para $70 \%$. Nos tratamentos com adubação completa foram utilizados: $100 \mathrm{mg} \mathrm{K} \mathrm{kg}^{-1}$ solo (como nitrato de potássio), $100 \mathrm{mg} \mathrm{P} \mathrm{kg}^{-1}$ solo (como super fosfato simples) e $100 \mathrm{mg} \mathrm{N} \mathrm{kg}^{-1}$ solo (como sulfato de amônio).

As quantidades de biossólidos foram definidas de acordo com os mesmos critérios citados no ítem 3.1.4 As doses foram calculadas a partir da dose ideal ou equivalente ao fornecimento de $150 \mathrm{~kg} \mathrm{~N} \mathrm{ha}^{-1}\left(37,2 \mathrm{~g} \mathrm{~kg}^{-1}\right.$ ou 12 $\mathrm{Mg} \mathrm{ha}^{-1}$ (Raij et al., 1996). As outras doses foram:

Para o biossólido da ETE-Franca:

Dose 1 - controle sem aplicação de biossólido

Dose 2 - 18,6 $\mathrm{g} \mathrm{kg}^{-1}$ ou $6 \mathrm{Mg} \mathrm{ha}^{-1}$ (metade da ideal)

Dose 4 - 74,4 $\mathrm{g} \mathrm{kg}^{-1}$ ou $24 \mathrm{Mg} \mathrm{ha}^{-1}$ (2 vezes a ideal)

Dose 5 - 297,6 $\mathrm{g} \mathrm{kg}^{-1}$ ou $96 \mathrm{Mg} \mathrm{ha}^{-1}$ (8 vezes a ideal).

Para o biossólido da ETE-Barueri:

Dose 1 - controle sem aplicação de biossólido

Dose 2 - 53,1 $\mathrm{g} \mathrm{kg}^{-1}$ ou $31 \mathrm{Mg} \mathrm{ha}^{-1}$ (metade da dose 3 )

Dose 3 - 106,2 $\mathrm{g} \mathrm{kg}^{-1}$ ou $62 \mathrm{Mg} \mathrm{ha}^{-1}$ (150 kg N ha-1)

Dose 4 - 212,4 $\mathrm{g} \mathrm{kg}^{-1}$ ou $124 \mathrm{Mg} \mathrm{ha}^{-1}$ (2 vezes a dose 3 )

As sementes de milho Dina 766 (Dina Milho, SP) foram desinfestadas superficialmente com solução de hipoclorito de sódio comercial 
$(1: 2, \mathrm{v} / \mathrm{v})$ por $5 \mathrm{~min}$, e lavadas com água destilada esterilizada. O plantio foi realizado após 60 dias de incubação dos solos com os biossólidos em casa-devegetação. Dez dias após a emergência, foi feito um desbaste, deixando-se 2 plantas por vaso. As plantas foram cultivadas em casa-de-vegetação por oito semanas e a umidade do solo foi mantida em aproximadamente $80 \%$ da capacidade máxima de retenção de água no solo, através de regas sempre que necessário.

O experimento foi realizado em casa-de-vegetação nas dependências do Departamento de Solos e Nutrição de Plantas, ESALQ, durante os meses de Junho-Setembro de 2000. As amostragens de solos tratados foram realizadas 30 e 60 dias após o plantio de milho. Em cada coleta, foram retirodas, aproximadamente $100 \mathrm{~g}$ de solo de cada parcela, obtendo-se uma amostra composta para cada tratamento, sendo utilizada para extração de DNA total.

\subsection{Extração de DNA total do solo}

O DNA total do solo foi extraído de amostras compostas, obtidas da mistura de quantidades iguais de cada parcela, para todos os tratamentos, utilizando-se o kit FastDNA Spin for Soil e o Cell Disruptor (Bio101, Vista, California). Em microtubos contendo granada finamente moída, foi adicionado 0,5 g de solo, $978 \mu \mathrm{L}$ de tampão fosfato, $122 \mu \mathrm{L}$ de Tampão MT. Estes tubos foram agitados, horizontalmente, por $30 \mathrm{~s} \mathrm{a} 4 \mathrm{~m} \mathrm{~s}^{-1}$, em um FP120 FastPrep Cell Disruptor (Bio101, Vista, California). Em seguida, centrifugou-se por $130 \mathrm{~s}$ a $14000 \mathrm{~g}$. O sobrenadante foi transferido para um tubo limpo. A essa solução adicionaram-se $250 \mu \mathrm{L}$ de Tampão PPS (para precipitação de proteínas), agitando-se os tubos 10 vezes por inversão. Os tubos foram novamente centrifugados por 5 min à $14000 \mathrm{~g}$, o sobrenadante coletado e transferido para um microtubo novo ao qual adicionou-se $1 \mathrm{~mL}$ de matriz de ligação (sílica 
ativada com tiocianato de guanidina), Agitando-se os tubos 3 vezes, por inversão. Em seguida os tubos foram incubados pôr $3 \mathrm{~min}$, a sílica foi transferida para um filtro acoplado a um microtubo (Spin Filter), e os tubos centrifugados por $1 \mathrm{~min}$ a $14000 \mathrm{~g}$. A sílica retida no filtro foi lavada com $500 \mu \mathrm{L}$ de uma solução de lavagem com sal-etanol (SEWS), e o filtro centrifugado 2 vezes por $1 \mathrm{~min}$ a $14000 \mathrm{~g}$. Após $5 \mathrm{~min}$ de incubação à temperatura ambiente, foram adicionados $50 \mu \mathrm{L}$ de água ultrapura ao filtro, centrifugou-se por $1 \mathrm{~min}$ a $14000 \mathrm{~g}$, e o DNA puro foi recolhido em um tubo limpo.

A concentração de DNA foi éstimada por espectrofotometria a 260 nm, em Espectrofotômetro Hewllet Packard 8453E, de acordo com Sambrook et al. (1989). A pureza do DNA foi estimada pela determinação das relações $A_{260} / A_{280}$ e $A_{260} / A_{230}$ para estimar a contaminação por proteínas e ácidos húmicos, respectivamente (Zhou et al., 1996; Sambrook et al., 1989; Tsai \& Olson, 1991). A integridade do DNA foi determinada por eletroforese em gel de agarose 0,8\%-TBE (45 mM Tris-borato, $1 \mathrm{mM}$ EDTA, pH 8,0). O DNA foi visualizado através de coloração com SYBR-Green I (Molecular Probes, Eugene, Oregon) em um densitômetro laser Fluorlmager (Molecular Dynamics).

\subsection{Amplificação do rDNA 16S por PCR:}

A amplificação por PCR de fragmentos específicos do rDNA 165 de Bacteria foi feita utilizando-se dois conjuntos de iniciadores: BA338fGC e UN518r; BA63fGC e UN518r (Quadro 3) (Øvreås et al., 1997; Fantroussi et al., 1999). A amplificação por PCR foi feita, em solução contendo: tampão para PCR $1 \mathrm{X} ; 0,3 \mathrm{mM}$ dNTP; 3,0 mM MgCl$;$; 1,5 U de Taq DNA polimerase (Gibco); $5 \mathrm{ng}$ de DNA total; $25 \mathrm{pmol}$ de cada um dos iniciadores; água Milli-Q esterilizada para um volume total de $50 \mu \mathrm{L}$. A amplificação foi realizada em um termociclador (Perkin-Elmer) usando a seguinte ciclagem: $95^{\circ} \mathrm{C}$ por $5 \mathrm{~min}, 30$ ciclos de $92^{\circ} \mathrm{C}$ por $1 \mathrm{~min}, 55^{\circ} \mathrm{C}$ por $1 \mathrm{~min}, 72^{\circ} \mathrm{C}$ por $1 \mathrm{~min} ; 72^{\circ} \mathrm{C}$ por $10 \mathrm{~min} ; 4^{\circ} \mathrm{C}$. 
O DNA foi adicionado à mistura de reação após desnaturação a $96^{\circ} \mathrm{C}$ por 10 min. A eficiência da amplificação, bem como seu rendimento, foram avaliados por densitometria, após eletroforese em gè de agarose 1,5\%-TBE (45 mM Trisborato, $1 \mathrm{mM}$ EDTA pH 8,0). Um marcádor de massa (DNA mass ladder, Gibco), foi utilizado como padrão, por comparação de tamanho e quantidade, dos fragmentos obtidos em cada tratamento, com o auxílio do programa Fragment Analysis (Molecular Dynamics)

\begin{tabular}{|l|l|}
\hline INICIADORES & \multicolumn{1}{|c|}{ 'SEQÜÉNCIA } \\
\hline BA338fGC & $5^{\prime}$ GCCCGCCGCGCGCGGCGGGCGGGGCGGGGGCACGG \\
& ACTCCTACGGGAGGCAGCAG 3' \\
BA63fGC & 5' CGCCCGCCGCGCGCGGCGGGCGGGGCGGGGGCACG \\
& GCAGGCCTAACACATGCAAGTC 3' \\
UN518r & $5^{\prime}$ ATTACCGCGGCTGCTGG 3' \\
\hline
\end{tabular}

Quadro 3. Seqüências de nucleotídeos dos iniciadores utilizados nos experimentos.

\subsection{Eletoforese em gel de poliacrilamida com gradiente desnaturante} (DGGE)

Os produtos da amplificação de rDNA 165 representando genótipos bacterianos, com diferentes concentrações de GC, foram separados por eletroforese, em gel de poliacrilamida (8\%) com gradiente desnaturante (DGGE). Os géis ( $8 \%(\mathrm{~m} / \mathrm{v})$ de acrilamida:bisacrilamida 37,5:1 $1 \mathrm{~m} / \mathrm{m})$ ), foram preparados com gradiente desnaturante variando de 15 a $55 \%$, usando duas soluções: uma solução $100 \%$ de capacidade desnaturante, contendo $7 \mathrm{M}$ uréia e $40 \%$ formamida; a outra solução não contém uréia ou formamida ( $0 \%$ ) (Øvreås et al., 1997). A eletroforese foi feita a $60^{\circ} \mathrm{C}, 100 \mathrm{~V}$ constantes por $5 \mathrm{hs}$, em um sistema de eletroforese vertical DC-code (BioRad), utilizando solução tampão 1X (40 mM Tris-acetato, $1 \mathrm{mM}$ EDTA pH 8,0). Após a eletroforese, o gel foi 
fixado em uma solução $10 \%$ de ácido acético glacial por 15 min e colocado em solução de SYBR-Green I (1:10000) (Molecular Probe, Eugene, Oregon) "overnight". Decorrido este período, o gel foi lavado 3 vezes, com troca de água a cada $3 \mathrm{~min}$, e analisado por densitometria. No segundo experimento, a separação dos amplicons foi feita por eletroforese, em gel de poliacrilamida (8\% e 6\%) para os inicidores BA338fGC/UN518r e BA63fGC/UN518r, respectivamente (Øvreås et al., 1997; Fantroussi et al, 1999). Os géis foram preparados com gradiente desnaturante variando de 15 a $55 \%$ e 10 a $45 \%$, para os iniciadores BA338fGC/UN518r e BA63fGC/UN518r, respectivamente. A eletroforese foi realizada à $200 \mathrm{~V}$ constante, $60^{\circ} \mathrm{C}$ por $3 \mathrm{~h}$, em tampão TAE 0,5 $X$ (40 mM Tris-acetato; 1 mM EDTA pH 8,0). Após a eletroforese, o DNA foi fixado em solução $10 \%$ de ácido acético glacial por $15 \mathrm{~min}$, lavado por $1 \mathrm{~min}$, colocado em solução de metanol $50 \%$ por $15 \mathrm{~min}$, novamente lavado por $1 \mathrm{~min}$ e finalmente colocado em solução de SYBBR-Green I (1:10000 v/v) por $30 \mathrm{~min}$ no escuro. Após este período, o gel foi lavado 3 vezes trocando-se a água a cada $3 \mathrm{~min}$, e analisado por densitometria, utilizando-se um densitômetro laser Fluorlmager (Molecular Dynamics) e o.programa Fragment Analysis (Molecular Dynamics).

\subsection{Aquisição e análise de imagem dos géis}

Os géis de agarose e poliacrilamida foram analisados por densitometria, utilizando um densitồmetro laser Fluorlmager (Molecular Dynamics). Em gel de agarose, a presença do marcador de massa, permitiu a quantificação dos produtos da reação de PCR, por comparação da fluorescência emitida pelo SYBR Green I (Molecular Probes, Eugene, Oregon). Em gel de poliacrilamida, as bandas de DNA foram localizadas e suas distâncias relativas de migração $e$ intensidade de fluorescência foram determinadas pelo programa Fragment Analysis (Molecular Dynamics). Determinou-se também a abundância relativa de cada amplicon, através da 
relação entre a fluorescência de cada um, em relação ao total de amplicons da amostra.

\subsection{Análise da estrutura das comunidades de Bacteria}

A similaridade entre as estruturas de comunidades de Bacteria, em cada tratamento com biossólido em cada tipo de solo, foi avaliada pela análise de agrupamento hierárquico, com base na análise dos resultados do PCRDGGE de porções dos rDNAs 16S. Os valores referentes à distância de migração dos amplicons nos géis de poliacrilamida foram usados para diferenciar os amplicons. A presença ou ausência de amplicons de mesmo Rf, percentagem da distância de migração, nas diferentes amostras foi computada e as matrizes de similaridade (índice de concondância simples) foram calculados.

Os índices de similaridade pelo algoritmo, concordância simples ("simple matching") incluem todos os amplicons detectados, para o conjunto de amplicons avaliados, nas comparações dois a dois, mesmo que não estejam presentes em nenhum dos dois indivíduos. Assim, tanto a presença como a ausência de bandas é considerada como indicador de similaridade (Sneath \& Sokal,1973). Este coeficiente é calculado conforme a equação abaixo:

$$
S i j=(a+d)(a+b+c+d)^{-1} \text {; }
$$

onde: $\quad S=$ similaridade;

i e j = diferentes tratamentos;

$a=$ amplicons presentes nos tratamentos $\mathrm{i}$ e $\mathrm{j}$

$b=$ amplicons presentes nos tratamentos $i$

$\mathrm{C}=$ amplicons presentes nos tratamentos $\mathbf{j}$

$\mathrm{d}=$ amplicons ausentes nos tratamentos $\mathrm{i} \mathbf{e} \mathbf{j}$ 
As matrizes geradas foram usadas para o agrupamento hierárquico, através do algoritmo de Ward (Sneath \& Sokal,1973; Quicke, 1993; Eichner et al.; 1999) utilizando a distância euclidiana como unidade de medida. O cálculo das matrizes de similaridade e o agrupamento hierarquico foram realizados com o programa Systat (SPSS, 1998).

\subsection{Análise da diversidade genética das comunidades de Bacteria}

Para a estimativa da diversidade genética de Bacteria em cada tratamento, foram calculados: $\mathrm{R}$, riqueza de espécies (número de amplicons em cada tratamento); $\mathrm{H}$, índice de diversidade de Shannon-Weaver; $\mathrm{S}$, índice de dominância de Simpson; E, eqüitabilidade de amplicons (Ampe \& Miambi, 2000; Jørgensen, 1992; Eichner et al., 1999). O índice de diversidade de ShannonWeaver foi calculado de acordo com a equação:

$$
H=-\Sigma p_{i} \log _{2} p_{i} \therefore \quad p_{i}=\frac{n_{i}}{\Sigma n_{i}}
$$

onde: $\quad \mathrm{H}=$ índice de diversidade Shannon-Weaver

$n_{i}=$ abundância (fluorescência) do amplicon

$p_{i}=$ abundância relativa do amplicon na amostra

O índice de dominância de Simpson (S) foi calculado segundo a equação:

$$
\text { onde: } \quad \begin{aligned}
& S=\Sigma p_{i}^{2} \\
& S=\text { índice de dominância de Simpson } \\
& p_{i}=\text { probabilidade do amplicon na amostra }
\end{aligned}
$$

A eqüitabilidade de amplicons foi calculada segundo a equação:

$$
E=\frac{H}{\log _{2} R}
$$


onde: $\quad E=$ eqüitabilidade de amplicons

$\mathrm{H}=$ índice de diversidade

$\mathrm{R}=$ número de amplicons

\subsection{Caracterização de amplicons}

Após a análise de cada gel de poliacrilamida, o DNA de amplicons foi recuperado do gel, cortando-se a seção do gel contendo o amplicon desejado com um bisturi esterilizado e transferindo a para um tubo de microcentrífuga de $0,6 \mathrm{~mL}$. À seção do gel foram adicionados: $50 \mu \mathrm{L}$ de uma solução contendo 10 $\mathrm{mM}$ Tris-HCL (pH 7,0), $50 \mathrm{mM} \mathrm{KCl}, 1,5 \cdot \mathrm{mM} \mathrm{MgCl}_{2}, 0,1 \%$ Triton 100X. Após a incubação da solução por $12 \mathrm{~h}$ a $4: \mathrm{C}$; retirada de uma alíquota de $5 \mu \mathrm{L}$ foi usada para reamplificação por PCR, utilizahdo-se o iniciador BA338f/UN518r. O DNA reamplificado foi purificado em gel de agarose 0,8\%-TBE e seqüenciado diretamente, ou clonado previà.emte aó seqüenciamento dependendo da eficiência da clonagem.

Para clonagem foi utiliżado o kit SureClone, conforme instruções do fabricante (SureClone ${ }^{\mathrm{TM}}$ Ligation Kit; Amersham Pharmacia Biotech). O processo envolve das seguintes etapas: reparo das extremidades dos produtos de PCR com as enzimas Klenow e pólinucleotídio quinase, purificação do inserto e ligação ao vetor pUC18. Célulàs competentes de E.coli $\mathrm{H} 5 \alpha$ foram transformadas por choque térmico a $42^{\circ} \mathrm{C}$ por $2 \mathrm{~min}$, com o vetor contendo o inserto de interesse. Foram plaqueados $50 \mu \mathrm{L}$ da suspensão de células transformadas em meio LB-ágar conténdo ampicilina $\left(50 \mu \mathrm{gL}^{-1}\right), X$-Gal (5-

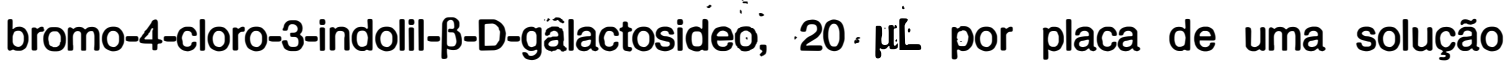
estoque $10 \%$, diluido em dimetilformamida concentrada) e IPTG (isopropiltio- $\beta$ D-galactosideo, $20 \mu \mathrm{L}$ por placa de uma solução eštoque $200 \mathrm{mM}$, em água). As células foram incubadas a $37^{\circ} \mathrm{C}$ por $12 \mathrm{~h}$. As colônias brancas (contendo o vetor 
recombinante) foram isoladas e multiplicadas em meio LB líquido contendo ampicilina. A confirmação da presença do inserto foi feita através da amplificação por PCR, utilizando DNA plasmidal como molde e os iniciadores $F$ e UN518r.

O sequenciamento foi feito através do método de Sanger et al. (1977), utilizando-se um seqüenciador àutomático ABI PRISM 377 (PerkinElmer). As seqüências obtidas foram comparadas com seqüências depositadas em bancos de dados públicos (GenBank), para possível identificação das espécies bacterianas. 


\section{RESULTADOS E DISCUSSÃO}

\subsection{Experimento 1: Alterações da estrutura da comunidade de Bacteria em solo argiloso não-cultivado tratado com biossólido da ETE-Franca}

\subsubsection{Análises químicas e físicas do solo e do biossólido utilizados}

O solo de textura argilosa utilizado apresenta alto conteúdo de matéria orgânica, alta CTC e argila total, conforme os resultados das análises químicas e físicas das amostras (Tabela 1). Em geral, solos argilosos e com alta CTC têm maior capacidade de adsorver íons metálicos, reduzindo sua disponibilidade e possível efeito tóxico sobre a microbiota (Ross, 1994). Além disso, a presença de altas concentrações de colóides orgânicos, contribui para diminuir a disponibilidade de metais pesados no solo (Killham, 1994).

O biossólido da ETE-Franca utilizado no experimento, apresenta pH 8,0 e alto conteúdo de matéria orgânica, conforme os resultados das análises químicas e físicas das amostras (Tabela 2). Isto pode favorecer o crescimento de microrganismos heterotróficos no solo e contribuir para o condicionamento do solo, melhorando a estabilidade dos agregados, distribuição de poros, capacidade de infiltração, além de aumentar o conteúdo de húmus. 
Tabela 1. Características químicas e físicas do solo utilizado no experimento.

\begin{tabular}{|c|c|}
\hline ATRIBUTOS & $\begin{array}{l}\text { NITOSSOLO VERMELHO } \\
\text { Eutroférrico típico }\end{array}$ \\
\hline $\mathrm{pH}\left(\mathrm{CaCl}_{2} 0,01 \mathrm{M}\right)$ & 4,9 \\
\hline Matéria orgânica $\left(\mathrm{g} \mathrm{dm}^{-3}\right)$ & 30,0 \\
\hline$P\left(\mathrm{mg} \mathrm{dm}^{-3}\right)$ & 24,0 \\
\hline $\mathrm{S}-\mathrm{SO}_{4}\left(\mathrm{mg} \mathrm{dm}^{-3}\right)$ & 38,0 \\
\hline $\mathrm{K}^{+}\left(\mathrm{mmol}_{\mathrm{c}} \mathrm{dm}^{-3}\right)$ & 4,3 \\
\hline $\mathrm{Ca}^{2+}\left(\mathrm{mmol}_{\mathrm{c}} \mathrm{dm}^{-3}\right)$ & 52,0 \\
\hline $\mathrm{Mg}^{2+}\left(\mathrm{mmol}_{\mathrm{c}} \mathrm{dm}^{-3}\right)$ & 18,0 \\
\hline $\mathrm{H}+\mathrm{Al}\left(\mathrm{mmol}_{\mathrm{c}} \mathrm{dm}^{-3}\right)$ & 42,0 \\
\hline $\mathrm{SB}\left(\mathrm{mmol}_{\mathrm{c}} \mathrm{dm}^{-3}\right)$ & 74,3 \\
\hline CTC $\left(\mathrm{mmol}_{\mathrm{c}} \mathrm{dm}^{-3}\right)$ & 116,3 \\
\hline$V(\%)$ & 64,0 \\
\hline Areia muito grossa (1-2 mm) (\%) & 1,0 \\
\hline Areia grossa $(0,5-1 \mathrm{~mm})(\%)$ & 1,0 \\
\hline Areia média $(0,25-0,5 \mathrm{~mm})(\%)$ & 5,0 \\
\hline Areia fina $(0,1-0,25 \mathrm{~mm})(\%)$ & 15,0 \\
\hline Areia muito fina $(0,05-0,1 \mathrm{~mm})(\%)$ & 4,0 \\
\hline Areia total $(0.05-2 \mathrm{~mm})(\%)$ & 26,0 \\
\hline Silte $(0,002-0,05 \mathrm{~mm})(\%)$ & 16,0 \\
\hline Argila dispersa em água $(<0,002)(\%)$ & 43,0 \\
\hline Argila total $(<0,002 \mathrm{~mm})(\%)$ & 58,0 \\
\hline
\end{tabular}


Tabela 2. Características químicas do biossólido da ETE-Franca utilizado no experimento.

\begin{tabular}{|c|c|}
\hline ATRIBUTO & BIOSSÓLIDO \\
\hline $\mathrm{pH}\left(\mathrm{CaCl}_{2} 0,01 \mathrm{M}\right)$ & 8,0 \\
\hline $\mathrm{H}_{2} \mathrm{O}\left(\mathrm{g} \mathrm{kg}^{-1}\right)$ & 845,1 \\
\hline Carbono total $\left(\mathrm{g} \mathrm{kg}^{-1}\right)$ & 409,9 \\
\hline Carbono Orgânico $\left(\mathrm{g} \mathrm{kg}^{-1}\right)$ & 404,8 \\
\hline Resíduo Mineral total $\left(\mathrm{g} \mathrm{kg}^{-1}\right)$ & 261,5 \\
\hline Resíduo Mineral Insolúvel $\left(\mathrm{g} \mathrm{kg}^{-1}\right)$ & 94,3 \\
\hline Resíduo Mineral Solúvel $\left(\mathrm{g} \mathrm{kg}^{-1}\right)$ & 167,2 \\
\hline Nitrogênio total $\left(\mathrm{g} \mathrm{kg}^{-1}\right)$ & 54,9 \\
\hline Fósforo total $\left(\mathrm{g} \mathrm{kg}^{-1}\right)$ & 10,1 \\
\hline Potássio total $\left(\mathrm{g} \mathrm{kg}^{-1}\right)$ & 1,0 \\
\hline Cálcio total $\left(\mathrm{g} \mathrm{kg}^{-1}\right)$ & 16,1 \\
\hline Magnésio total $\left(\mathrm{g} \mathrm{kg}^{-1}\right)$ & 1,9 \\
\hline Enxofre total $\left(\mathrm{g} \mathrm{kg}^{-1}\right)$ & 4,5 \\
\hline Zinco total $\left(\mathrm{mg} \mathrm{kg}^{-1}\right)$ & 1046,0 \\
\hline Ferro total $\left(\mathrm{mg} \mathrm{kg}^{-1}\right)$ & 25739,0 \\
\hline Cobre total $\left(\mathrm{mg} \mathrm{kg}^{-1}\right)$ & 207,0 \\
\hline Manganês total ( $\left.\mathrm{mg} \mathrm{kg}^{-1}\right)$ & 52,0 \\
\hline Crômio total (mg kg-1) & 949,0 \\
\hline Níquel total $\left(\mathrm{mg} \mathrm{kg}^{-1}\right)$ & 47,0 \\
\hline Relação C/N & 7,0 \\
\hline
\end{tabular}


Tabela 3. Taxa anual máxima de metais permitida pela Norma P4.230 da CETESB (Estado de São Paulo, 1999) e taxa de metais aplicados no solo, de acordo com as dose definidas.

\begin{tabular}{cccccc}
\hline Metal & $\begin{array}{c}\text { Taxa máxima anual } \\
\left(\mathrm{Kg} \mathrm{ha}^{-1}\right)\end{array}$ & \multicolumn{4}{c}{$\begin{array}{c}\text { Dose de biossólido aplicada no solo } \\
\left(\mathrm{Mg} \mathrm{ha}^{-1}\right)\end{array}$} \\
\hline Cobre & & 6 & 12 & 24 & 48 \\
Crômio & $*$ & 1,22 & 2,44 & 4,88 & 9,44 \\
Níquel & 21 & 5,69 & 11,38 & 22,77 & 45,52 \\
Zinco & 140 & 0,28 & 0,56 & 1,13 & 2,25 \\
& & 6,27 & 12,55 & 25,10 & 50,2 \\
\hline
\end{tabular}

* Limite máximo: $1000 \mathrm{~kg} \mathrm{ha}^{-1}$ (Estado de São Paulo, 1999)

Metais pesados como $\mathrm{Zn}, \mathrm{Cu}$, Ni estão presentes em concentrações aceitáveis (Tabela 3). Dados relativos às quantidades aceitáveis de metal crômio nos biossólidos não estão ainda bem estabelecidos pela legislação, sendo recentes os estudos para estabelecimento destes limites, principalmente no Brasil (São Paulo, 1999).

A matéria orgânica incorporada ao solo via biossólido, favorece algumas características essenciais. Quando o biossólido, é adicionado ocorre a elevação do teor de matéria orgânica, aumento do $\mathrm{pH}$ e conseqüentemente aumento da CTC (Kilham, 1994). Dois processos importantes são então estimulados: a atividade microbiana e a produção de grupos funcionais efetivos no processo de troca catiônica. Isso possibilita uma maior competição entre as espécies químicas provenientes do solo e biossólido. Porém, em baixo pH $(4,8-$ $5,2)$ a ionização dos grupos funcionais da matéria orgânica capaz de induzir a formação de cargas negativas, não ocorre. Com o aumento do pH do solo, devido ao $\mathrm{pH}$ elevado do biossólido, cátions como $\mathrm{Fe}, \mathrm{Mn}, \mathrm{Zn}$ e $\mathrm{Cu}$ podem formar óxidos e hidróxidos insolúveis. Neste caso a concentração biodisponível 
destes metais é reduzida impedindo a sua toxicidade sobre a biomassa microbiana.

\subsubsection{Extração de DNA total do solo}

O DNA total extraído das amostras de solo imediatamente após a coleta das amostras apresentou alta massa molecular e baixa fragmentação (Figura 1).

$\mathrm{Na}$ Tabela 4 podem ser vistos os dados sobre a qualidade do DNA total extraído do solo. A análise da relação das absorbâncias da solução de DNA a 260 e $280 \mathrm{~nm}\left(A_{260} / A_{280}\right)$ foi utilizada para estimar a contaminação por proteínas. Os valores próximos a 2,00 denotam DNA com baixa contaminação protéica. Para estimar a presença de ácidos húmicos foi utilizada a relação entre as absorbâncias a 260 e $230 \mathrm{~nm}\left(A_{260} / A_{230}\right)$. Valores acima de 2,0 denotam baixo conteúdo de ácidos húmicos e portanto, DNA de alta qualidade. Em média a relação $A_{260} / A_{280}$ das amostras foi de 1,83 e a relação $A_{260} / A_{230}$ foi de 0,11 , sugerindo que o método utilizado para extração do DNA total do solo foi eficiente para remoção de contaminantes de origem protéica, mas teve baixa eficiência na remoção de ácidos húmicos das amostras. A presença de ácidos húmicos nas amostras não interferiu na amplificação do rDNA 16S por PCR.

\subsubsection{Amplificação de fragmentos do rDNA 16S}

Os produtos da amplificação por PCR (amplicons). do rDNA 16S com os iniciadores BA338fGC e UN518r (região V3), podem ser vistos na Figura 2. A amplificação resultou em um fragmento de DNA de aproximadamente 236 pares de base $(\mathrm{pb})$, condizente com o tamanho esperado, considerando-se 196 pb do rDNA e o "clamp" GC do iniciador BA338fGC. 


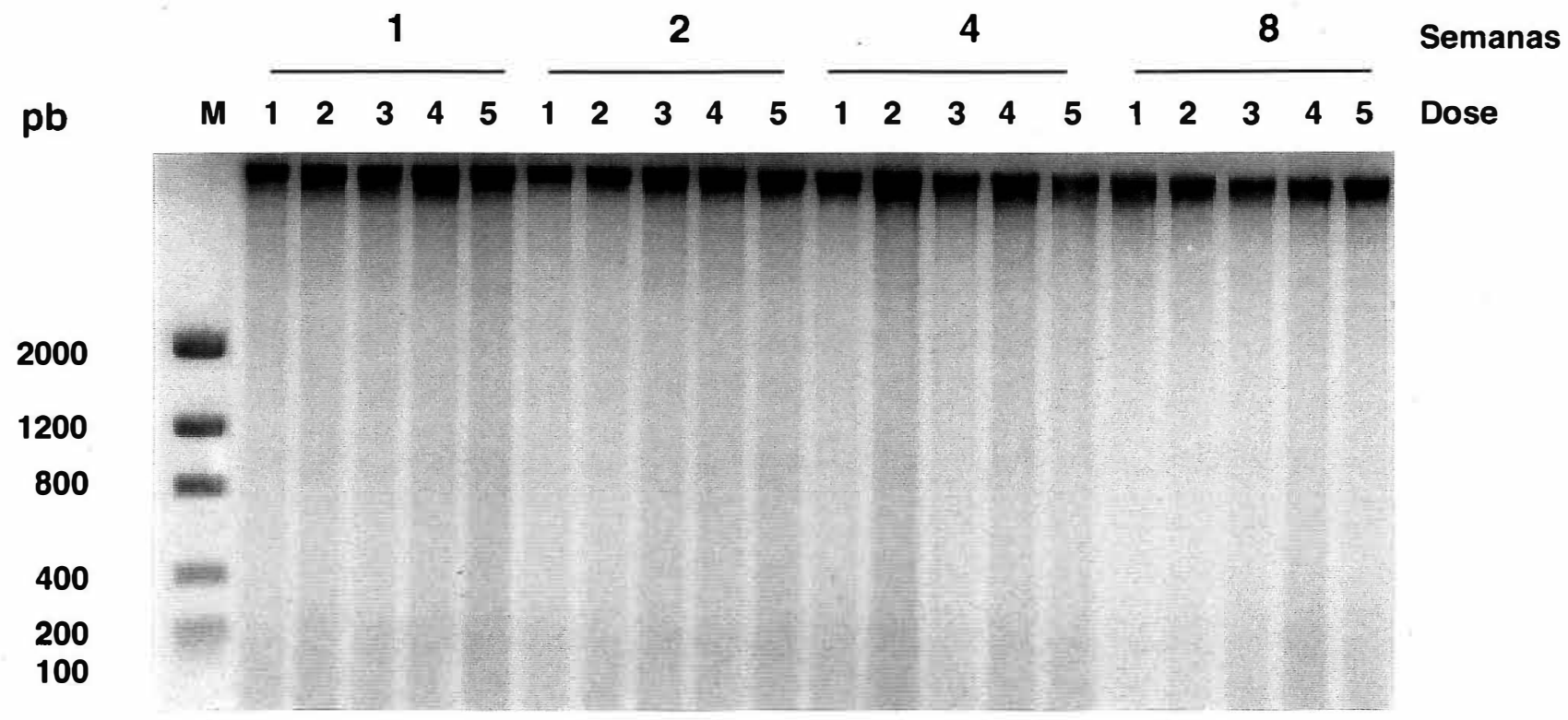

Figura 1 - DNA total extraído das amostras de solo argiloso tratadas com biossólido da ETE-Franca. M, marcador de massa molecular; Dose 1, sem adição de biossólido; Dose 2, $6 \mathrm{Mg} \mathrm{ha}^{-1}$; Dose 3, $12 \mathrm{Mg} \mathrm{ha}^{-}$ 1; Dose 4, $24 \mathrm{Mg} \mathrm{ha}^{-1}$; Dose 5, $48 \mathrm{Mg} \mathrm{ha}^{-1}$. O tempo de incubação está expresso em semanas. 


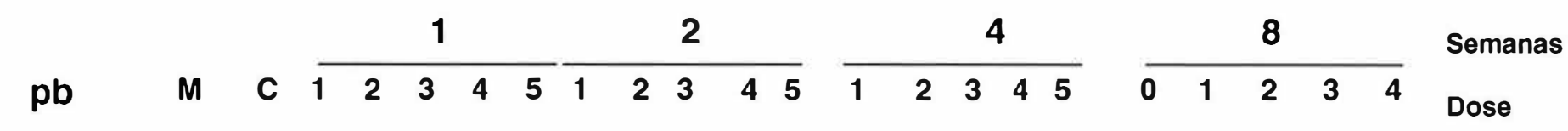

400

200

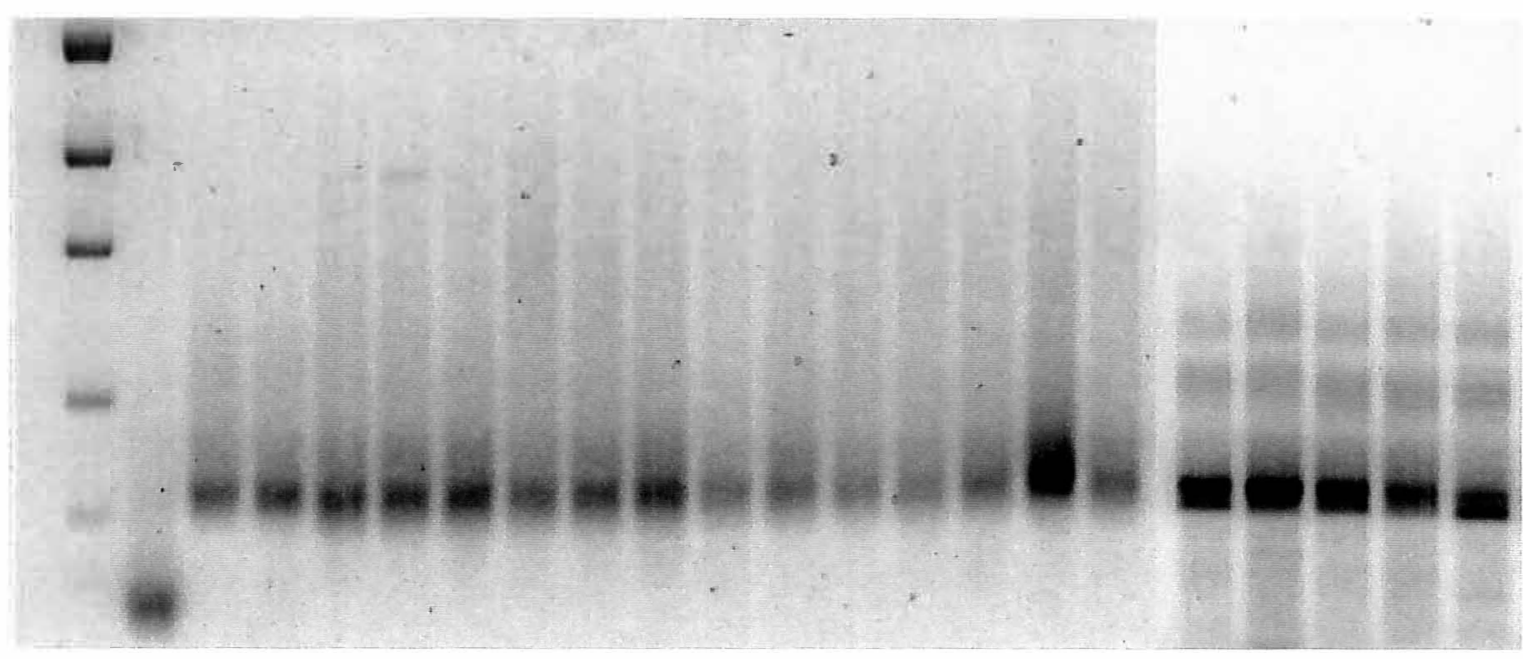

Figura 2 - Amplicons da região V3 do rDNA 165 da comunidade de Bacteria de solo argiloso tratado com biossólido da ETE-Franca. M, marcador de massa molecular. C, controle negativo, sem DNA; Dose 1, sem adição de biossólido; Dose 2, $6 \mathrm{Mg} \mathrm{ha}^{-1}$; Dose 3, $12 \mathrm{Mg} \mathrm{ha}^{-1}$; Dose 4, $24 \mathrm{Mg} \mathrm{ha}^{-1}$; Dose 5, $48 \mathrm{Mg} \mathrm{ha}^{-}$ '. O tempo de incubação está expresso em semanas. 
Tabela 4. Qualidade do DNA total extraído do solo argiloso tratado com biossólido da ETE-Franca.

\begin{tabular}{|c|c|c|c|}
\hline $\begin{array}{c}\text { Tempo de incubação } \\
\text { (semanas) }\end{array}$ & $\begin{array}{l}\text { Dose biossólido } \\
\qquad\left(\mathrm{Mg} \mathrm{ha}^{-1}\right)\end{array}$ & $A_{260} / A_{230}$ & $A_{260} / A_{280}$ \\
\hline \multirow[t]{5}{*}{1} & 0 & 0,0732 & 1,8836 \\
\hline & 6 & 0,0659 & 1,8905 \\
\hline & 12 & 0,0855 & 2,1758 \\
\hline & 24 & 0,0886 & 1,8779 \\
\hline & 48 & 0,0880 & 1,9571 \\
\hline \multirow[t]{5}{*}{2} & 0 & 0,0906 & 1,8677 \\
\hline & 6 & 0,1382 & 1,9728 \\
\hline & 12 & 0,1178 & 1,8421 \\
\hline & 24 & 0,2268 & 1,7493 \\
\hline & 48 & 0,1000 & 1,8509 \\
\hline \multirow[t]{5}{*}{4} & 0 & 0,1067 & 1,8459 \\
\hline & 6 & 0,0914 & 1,8720 \\
\hline & 12 & 0,1313 & 1,8602 \\
\hline & 24 & 0,1384 & 1,8591 \\
\hline & 48 & 0,1184 & 1,8485 \\
\hline \multirow[t]{2}{*}{8} & 0 & 0,1556 & 1,6906 \\
\hline & 6 & 0,1682 & 1,8000 \\
\hline & 12 & 0,1529 & 1,3678 \\
\hline & 24 & 0,0866 & 1,6463 \\
\hline & 48 & 0,0889 & 1,8400 \\
\hline
\end{tabular}

$A_{230}, A_{260}, A_{280:}$ absorbância da solução de DNA a 230,260 e 280 $\mathrm{nm}$, respectivamente. 


\subsubsection{Estrutura da comunidade de Bacteria}

A estrutura da comunidade de Bacteria refletiu a composição de espécies bacterianas de um solo argiloso tratado com biossólido da ETEFranca. Este solo foi avaliado por eletroforese em gel de poliacrilamida com gradiente desnaturante (DGGE) conforme Figura 3. A análise do gel de DGGE foi realizada com base na presença/ausência de amplicons, calculando similaridade e agrupamento hierárquico, entre os tratamentos em relação aos controles. Como critério de avaliação, cada banda no gel foi considerada como derivada de uma única espécie microbiana, podendo se relacionar com o número total de espécies presentes, embora, tem sido observado que algumas espécies bacterianas podem conter mais de uma cópia do rDNA, e produzir múltiplos amplicons (Fogel et al., 1999; Ibekwe et al., 2001).

A distribuição dos 20 amplicons presentes, com diferentes Rfs, pode ser vista na representação esquemática da Figura 4. Após 1 semana de incubação, os amplicons presentes nas amostras que receberam quantidades equivalentes a 24 e $48 \mathrm{Mg} \mathrm{ha}^{-1}$ de biossólido, apresentaram os amplicons Rf 0,083; 0,185; 0,$221 ; 0,249$, os quais não foram detectados no controle. Dois amplicons com Rfs 0,440 e 0,520 foram detectados apenas na amostra de solo tratada com quantidade equivalente a $12 \mathrm{Mg} \mathrm{ha}^{-1}$ e incubada por 1 semana. Após 2 semanas de incubação as amostras tratadas com quantidades equivalentes a 6 , 12 e $24 \mathrm{Mg} \mathrm{ha}^{-1}$ de biossólido apresentaram os amplicons de com Rfs 0,122; 0,$132 ; 0,157 ; 0,221 ; 0,308$, ausentes no controle. Neste Após 4 semanas de incubação, o controle e a amostra tratada com quantidade equivalente a $6 \mathrm{Mg}$ $\mathrm{ha}^{-1}$ apresentam em comum os amplicons com Rfs 0,122; 0,157; 0,175; 0,185; 0,221 . Este resultado mostra que amostras com baixa dose de biossólido foram mais similares ao controle, exceto após 8 semanas de incubação. 


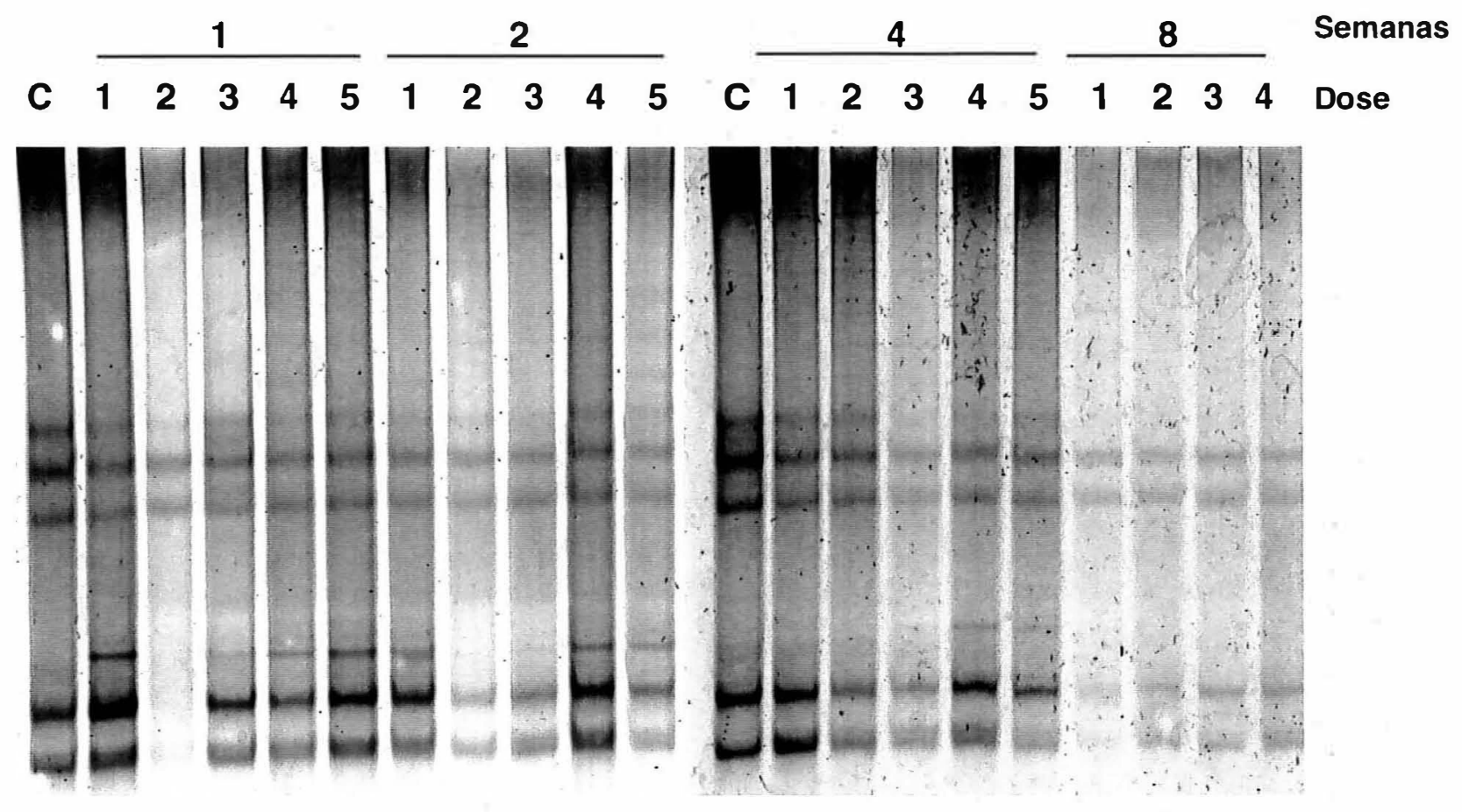

Figura 3 - Amplicons da região V3 do rDNA 16S da comunidade de Bacteria em solo argiloso tratado com biossólido da ETE-Franca. Os amplicons foram separados em gel de poliacrilamida $8 \%$, com gradiente desnaturante (15-55\%). O DNA foi visualizado por coloração com SYBR Green I. Dose 1, sem adição de biossólido; Dose 2, $6 \mathrm{Mg} \mathrm{ha}^{-1}$; Dose 3, $12 \mathrm{Mg} \mathrm{ha}^{-1}$; Dose 4, $24 \mathrm{Mg} \mathrm{ha}^{-1}$; Dose 5, $48 \mathrm{Mg} \mathrm{ha}^{-1}$. O tempo de incubação está expresso em semanas; C, controle (DNA do solo extraído na instalação do experimento; controle das condições de corrida). A amostra da Dose 5 com 8 semanas de incubação (T4) foi perdida. 


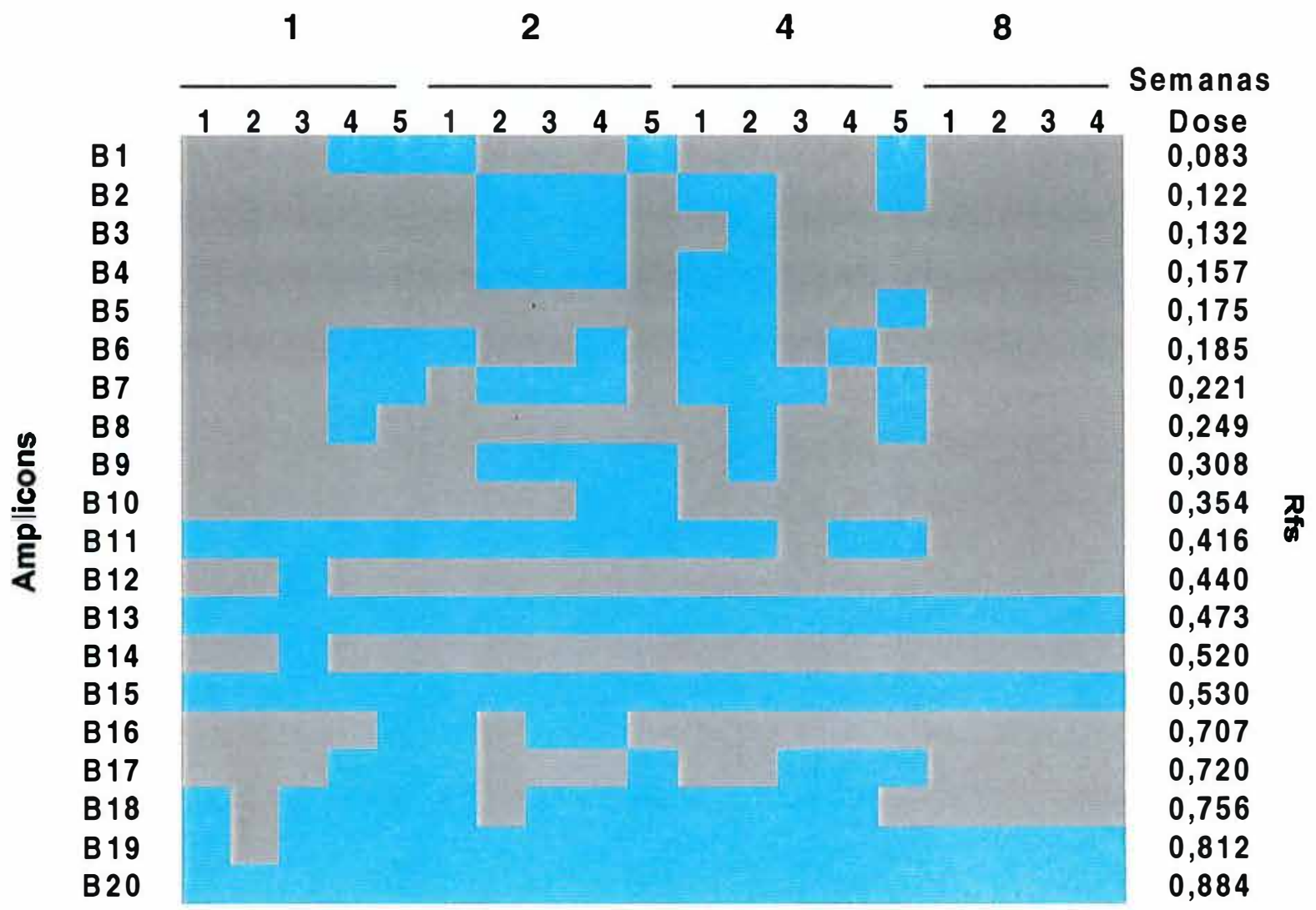

Figura 4 - Diagrama representando os amplicons da região V3 do rDNA 165 das comunidades de Bacteria de solo argiloso tratado com biossólido da ETE-Franca. Dose 1, sem adição de biossólido; Dose 2, $6 \mathrm{Mg} \mathrm{ha}^{-1}$; Dose 3, $12 \mathrm{Mg} \mathrm{ha}^{-1}$; Dose 4, $24 \mathrm{Mg} \mathrm{ha}^{-1}$; Dose 5, $48 \mathrm{Mg}$ $\mathrm{ha}^{-1}$. 
Nas amostras tratadas com as doses mais elevadas de biossólido, um decréscimo no número de amplicons foi observado. Após 8 semanas de incubação o número de amplicons nas amostras tratadas com biossólido foi drásticamente reduzido, mas significativamente igual ao controle.

As alterações na estrutura da comunidade de Bacteria foram avaliadas calculando o coeficiente de similaridade binário ("simple matching"), com o qual foi obtida uma matriz de similaridade (Tabela 5). Os resultados desta matriz mostram que a estrutura da comunidade de Bacteria do solo após 1 semana de incubação, apresentou em média $82,5 \%$ de similaridade em relação ao controle. Para as doses mais baixas de biossólido, o coeficiente de similaridade foi de $90 \%$. Já, nos tratamentos que receberam quantidades equivalentes a 24 e $48 \mathrm{Mg} \mathrm{ha}^{-1}$ de biossólido, o coeficiente de similaridade das comunidades de Bacteria foi em média $75 \%$ em relação ao controle. Após 2 semanas de incubação a estrutura da comunidade apresentou em média 62,5\% de similaridade em relação ao controle. Para as doses mais baixas de biossólido, o coeficiente de similaridade foi de $55 \%$. Já, nos tratamentos que receberam quantidades equivalentes a 24 e $48 \mathrm{Mg} \mathrm{ha}^{-1}$ de biossólido, o coeficiente de similaridade das comunidades de Bacteria foi em média $70 \%$ em relação ao controle. Após 4 semanas de incubação a estrutura da comunidade apresentou em média $75 \%$ de similaridade em relação ao controle. Para as doses mais baixas de biossólido, o coeficiente de similaridade foi de $77,5 \%$. Nos tratamentos que receberam quantidades equivalentes a 24 e $48 \mathrm{Mg} \mathrm{ha}^{-1}$ de biossólido, o coeficiente de similaridade das comunidades de Bacteria foi em média $72,5 \%$ em relação ao controle. Após 8 semanas de incubação, quatro amplicons foram dominantes, sendo encontrados durante todo experimento em todas as doses e épocas de amostragem (100\%). 


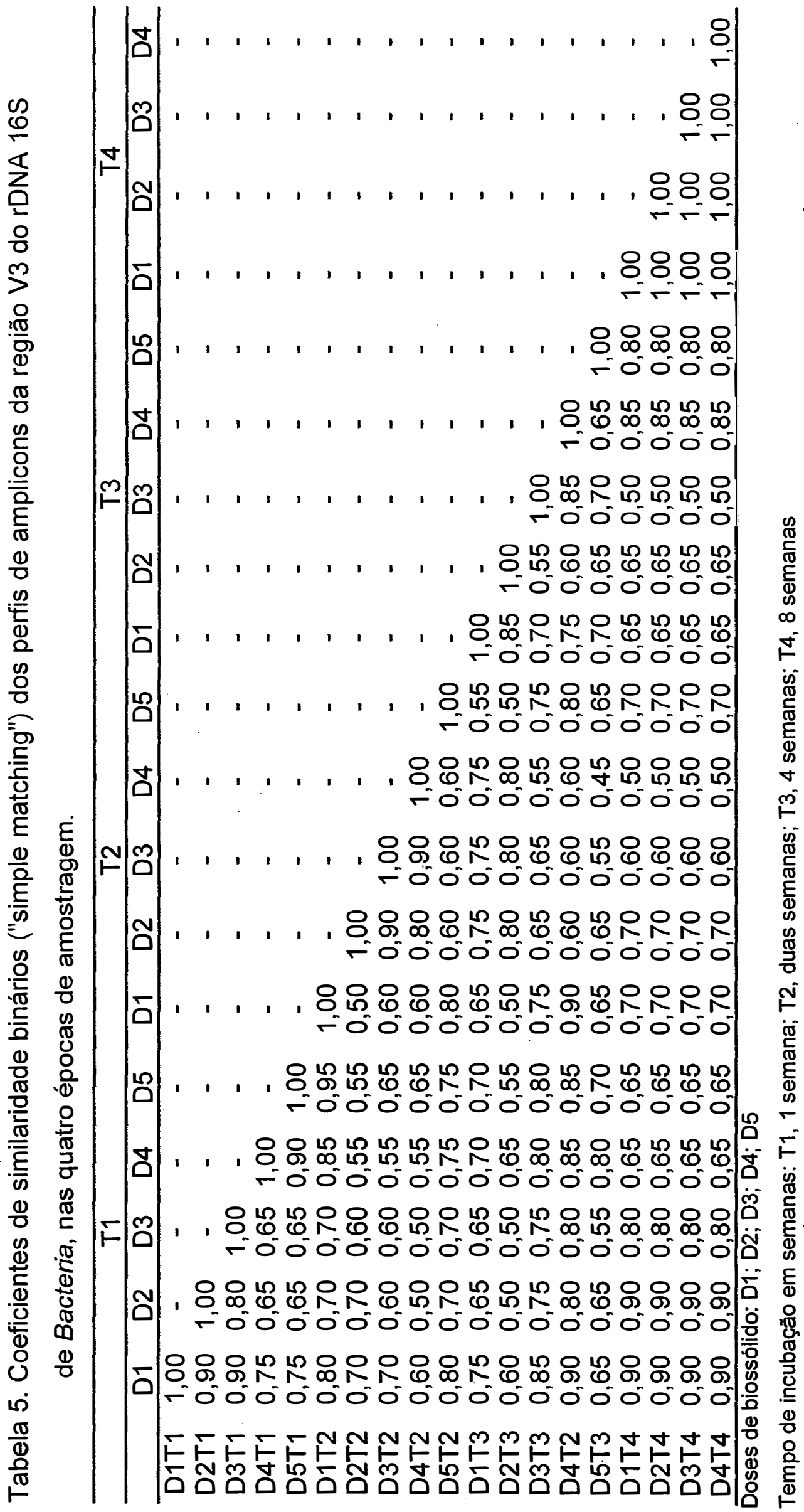


Além disso, os dados da Tabela 5 mostram que após 8 semanas de incubação a estrutura da comunidade de Bacteria das amostras tratadas com biossólido é semelhante a da amostra controle, coletada após 1 semana de incubação, provavelmente devido à limitação de nutrientes.

A análise de agrupamento, ressalta os resultados obtidos, demonstrando que as amostras tratadas com as doses mais baixas de biossólido a estrutura da comunidade de Bacteria foi mais similar aos controles, principalmente, após 1 e 8 semanas de incubação, sendo que nesta última, não foram detectadas diferenças entre as amostras. Foram detectados três grandes grupos (Figura 5). No grupo I, estão as amostras coletadas após 2 semanas de incubação, doses 1, 2 e 3 de biossólido; além do controle e a dose 1 (6 $\mathrm{Mg} \mathrm{ha}^{-1}$ ) do biossólido, coletados após quatro semanas. Este grupo caracteriza as amostras de solo com maior distúrbio com alterações adversas resultantes da adição e mineralização da matéria orgânica. No grupo II, estão todas as doses mais altas das amostras coletadas após 1,2 e 3 semanas de incubação, além do controle coletado após 2 semanas. As poucas diferenças entre as amostras que receberam a doses mais altas de biossólido fazem parte deste grupo. As amostras do grupo III são: solo tratado com quantidade equivalente a $6 \mathrm{Mg} \mathrm{ha}^{-1}$ de biossólido, coletado após 4 semanas de incubação; todas as doses da última amostragem e as doses mais baixas, além do controle, coletados após 1 semana de incubação. Isso demonstra a resiliência do sistema, visto que as amostras coletadas após 8 semanas de incubação estão agrupadas com as amostras coletadas após 1 semana de incubação, demonstrando a alta similaridade entre elas. 


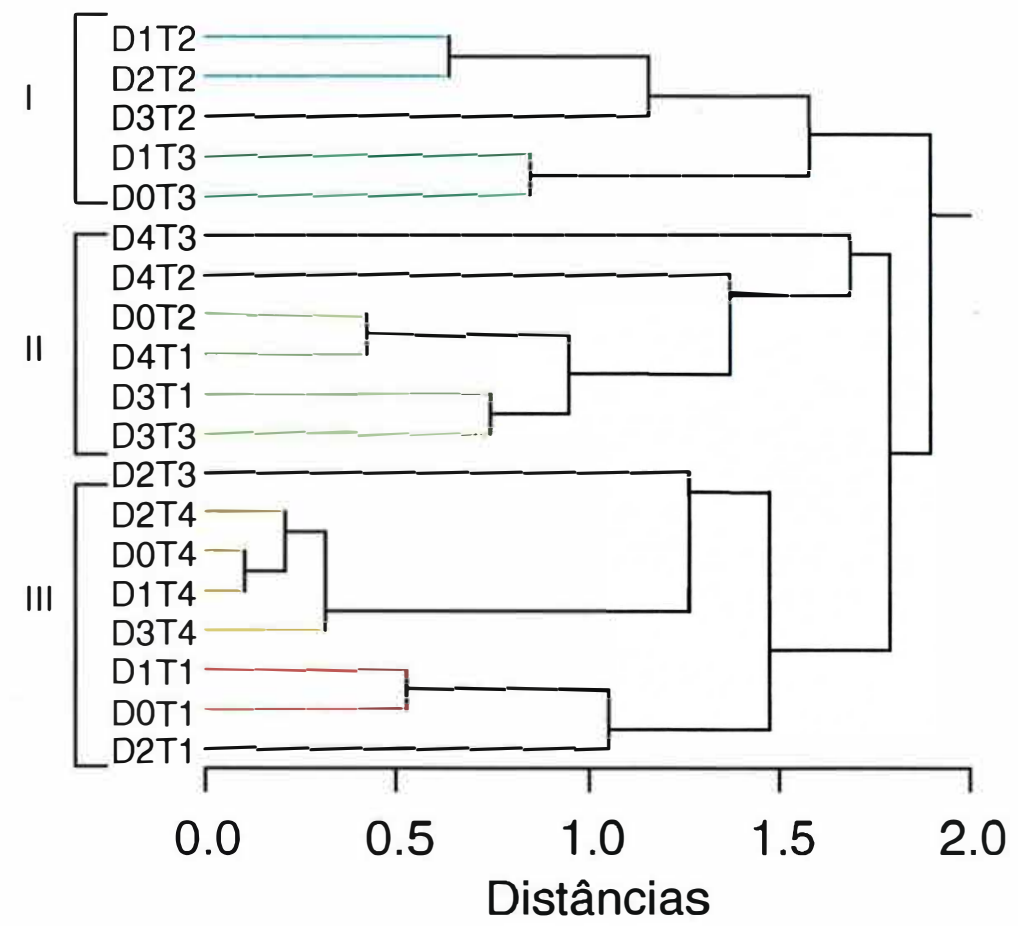

Figura 5 - Dendograma representando as relações entre os amplicons da região V3 do rDNA 165 da comunidade de Bacteria de solo argiloso tratado com biossólido da ETE-Franca. Dose 1, sem adição de biossólido; Dose 2, $6 \mathrm{Mg} \mathrm{ha}^{-1}$; Dose 3, $12 \mathrm{Mg} \mathrm{ha}^{-1}$; Dose 4, $24 \mathrm{Mg} \mathrm{ha}^{-1}$; Dose 5, $48 \mathrm{Mg} \mathrm{ha}^{-1}$. T1, 1 semana; T2, 2 semanas; T3, 4 semanas; T4, 8 semanas de incubação. 
Os coeficientes de similaridade das comunidades de Bacteria após a aplicação do biossólido da ETE-Franca, particularmente para as doses mais baixas de biossólido aplicadas, foram mais semelhantes aos controles sem adição de biossólidos. Porém, após 2 semanas de incubação, o número de amplicons teve um aumento temporário e os coeficientes de similaridade foram menores para as amostras que receberam as doses mais baixas de biossólido. Estas variações observadas podem ser explicadas em função da presença de um maior conteúdo de matéria orgânica e nutrientes e ainda como resultado das alterações nas propriedades físicas do solo como a maior distribuição de agregados e capacidade de retenção de água.

Resultados semelhantes foram observados por Lopes (dados não publicados), analisando solo argiloso tratado com biossólido da ETE-Franca. Após 2 semanas de incubação os valores de C-biomassa foram significativamente diferentes do controle sem biossólido. No decorrer do período de incubação, ocorreu um decréscimo nos valores de C-biomassa em função do tempo. Os resultados obtidos por Carmo (2000), mostram que após aproximadamente 18 dias de incubação do solo-biossólido, a mineralização da matéria orgânica induziu aumentos nas atividades metabólicas das bactérias do solo devido a grande disponibilidade de nutrientes, corroborando com os dados obtidos neste experimento. Além disso, para as doses mais altas de biossólido os coeficientes de similaridade foram superiores a $70 \%$ ao longo de todo o experimento. Isso pode ser explicado, considerando que a aplicação de grandes quantidades de biossólido implica em uma carga de matéria orgânica proporcionalmente grande, resultando em maior conteúdo de metais pesados adicionados. Porém, nas baixas concentrações em que se encontram os metais e a capacidade de adsorção do solo argiloso, o estresse por metais pesados não seria necessariamente o principal fator para alteração na estrutura da comunidade. Da mesma forma Lopes (dados não publicados), comparando amostras de solo argiloso tratado com biossólido, analisando a capacidade de 
utilização de substratos da comunidade microbiana. Maior similaridade foi observada entre a estrutura da comunidade dos solos tratados com baixas doses de biossólido e o controle sem biossólido. Quando doses elevadas de biossólido foram aplicadas, a maior similaridade entre estes tratamentos foi observada. Além disso, os tratamentos com doses mais elevadas, diferem do controle sem biossólidos. Após 8 semanas de incubação não foram identificadas diferenças entre os solos, sugerindo maior similaridade entre os tratamentos e portanto menor resistência e reliliência do sistema.

Leita et al. (1995) obtiveram a redução da toxicidade de metais pesados em função da textura do solo avaliada pela determinação do aumento no $\mathrm{qCO}_{2}$ de um solo contendo $\mathrm{Zn}$, confirmando a grande demanda de energia utilizada por microrganismos para evitar os efeitos da alta toxicidade exercida por este metal. Porém, a baixa toxicidade de $\mathrm{Pb}$ foi atribuída as prováveis interações do metal com o solo, evitando os efeitos tóxicos sobre a microbiota através de um efeito tampão. Giller et al. (1998) mostraram que os efeitos da disponibilidade de metais pesados podem resultar em alterações aleatórias nas taxas de respiração. Isso porque a morte das células aumenta a disponibilidade de substrato, modificando o ambiente e afetando os complexos com a matéria orgânica, tornando este menos disponível. Por isso, não se pode afirmar que estes resultados descrevem essencialmente os efeitos de metais pesados sobre a microbiota do solo, visto que, após 2 semanas de incubação, os microrganismos sofreram grande influência dos processos de mineralização da matéria orgânica devido às flutuações na disponibilidade de nutrientes presentes na mistura solo-biossólido.

Por outro lado, McGrath et al. (1995), estudando o impacto da aplicação de biossólidos sobre parâmetros microbiológicos, encontraram que o pH e a textura dos solos contribuem para a redução da toxicidade causada pelos metais, quando estes se encontram em alta concentração. FließBach et 
al. (1994) determinaram a alta eficiência na síntese de biomassa em solo tratados com pequenas quantidades de biossólido com baixa concentração de metais, mas não foram detectadas mudanças quantitativas na estrutura da comunidade do solo. Contudo, os dados mostraram que a estrutura da comunidade do solo foi modificada ao longo do tempo de incubação, demonstrando a resiliência do sistema.

\subsubsection{Análise dos índices de diversidade}

Nas Figuras 6 e 7, são mostrados os índices de diversidade, calculados a partir da estimativa de abundância relativa, obtidos nas análises de amplicons separados em gel de poliacrilamida com gradiente desnaturante. A amostra tratada com quantidade equivalente a $48 \mathrm{Mg} \mathrm{ha}^{-1}$ foi perdida e seus resultados, em relação aos índices de diversidade.

A riqueza de espécies (S), definida como o número de espécies que formam a comunidade de Bacteria presente em cada tratamento, foi avaliada ao longo do tempo de incubação. Na primeira semana de incubação os valores de $S$ obtidos para os solos que receberam quantidade de biossólido equivalente a 12, 24 e $48 \mathrm{Mg} \mathrm{ha}^{-1}(7)$ são semelhantes ao controle (6). Somente quando quantidade de biossólido equivalente a $6 \mathrm{Mg} \mathrm{ha}^{-1}$, o valor encontrado foi mais baixo (4), para o mesmo tempo de incubação. Após duas semanas de incubação do solo, os valores de $S$ duplicaram, não diferindo entre o controle e as amostras que receberam quantidades equivalentes a 6 e $48 \mathrm{Mg} \mathrm{ha}^{-1}$ (10). Para quantidades de biossólido equivalentes a 12 e $24 \mathrm{Mg} \mathrm{ha}^{-1}$ o $\mathrm{S}$ foi de $12 \mathrm{e}$ 14, respectivamente. Após 4 semanas, os controles e a quantidade equivalente a $48 \mathrm{Mg} \mathrm{ha}^{-1}$ obteve-se $S=11$, sendo superior nas doses equivalente a 6 e 12 $\mathrm{Mg} \mathrm{ha}^{-1}$ (14). Quando o solo foi tratado com quantidade de biossólido equivalente a $24 \mathrm{Mg} \mathrm{ha}^{-1} \mathrm{o}$ valor de $S$ foi 8 . Após 8 semanas, o $S$ foi 4 , independente da dose de biossólido aplicada. 


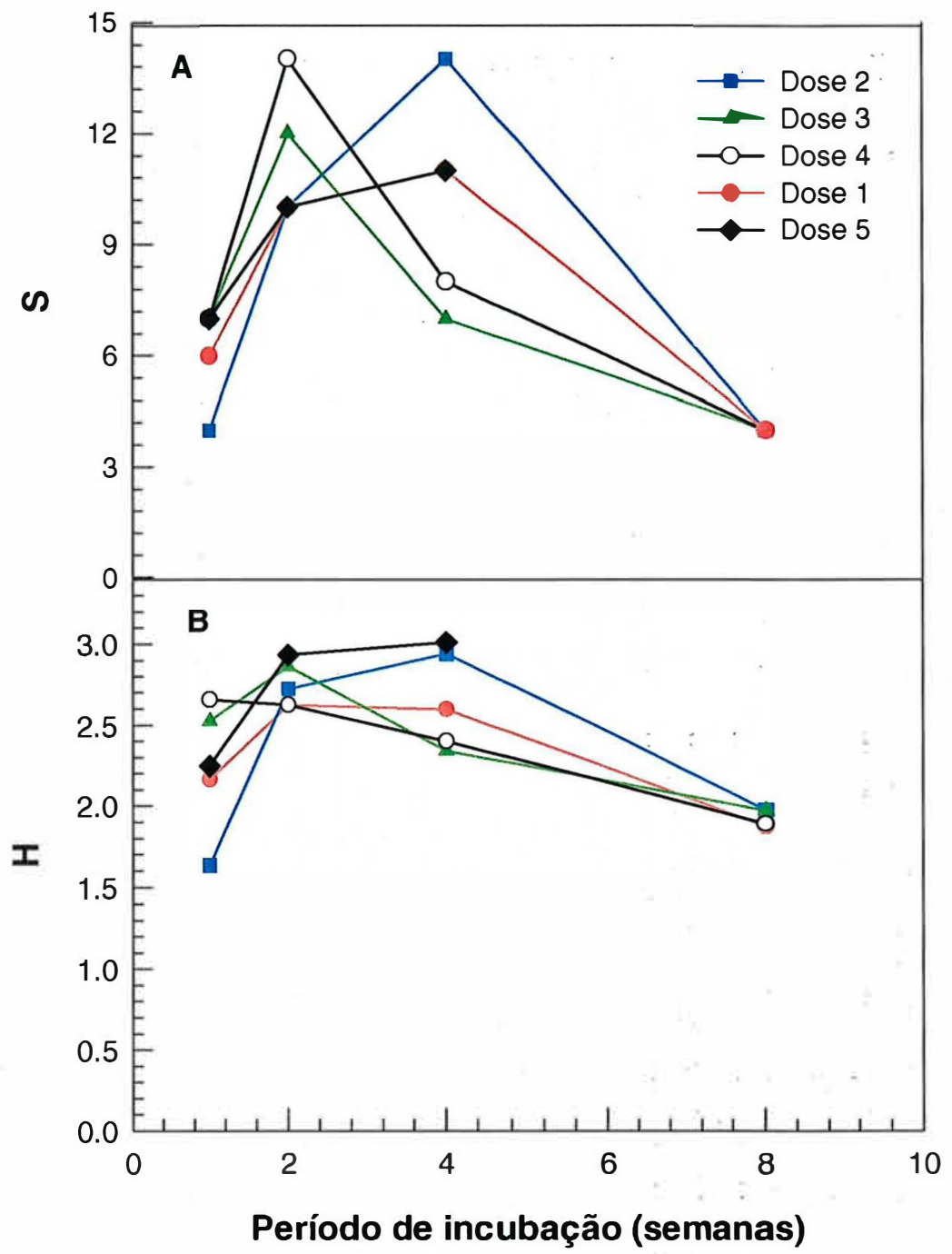

Figura 6 - Índices de diversidade. A, Riqueza de espécies (S); Índice de Shannon-Weaver $(H)$, de solo argiloso tratado com biossólido da ETE-Franca calculados a partir dos dados de abundância relativa dos amplicons em função do tempo de incubação do solo. Dose 1, sem adição de biossólido; Dose 2, $6 \mathrm{Mg} \mathrm{ha}^{-1}$; Dose 3, $12 \mathrm{Mg} \mathrm{ha}^{-1}$; Dose 4, $24 \mathrm{Mg} \mathrm{ha}^{-1}$; Dose 5, $48 \mathrm{Mg} \mathrm{ha}^{-1}, \mathrm{~T} 1,1$ semana; T2, 2 semanas; T3, 4 semanas; T4, 8 semanas após a aplicação do biossólido. 


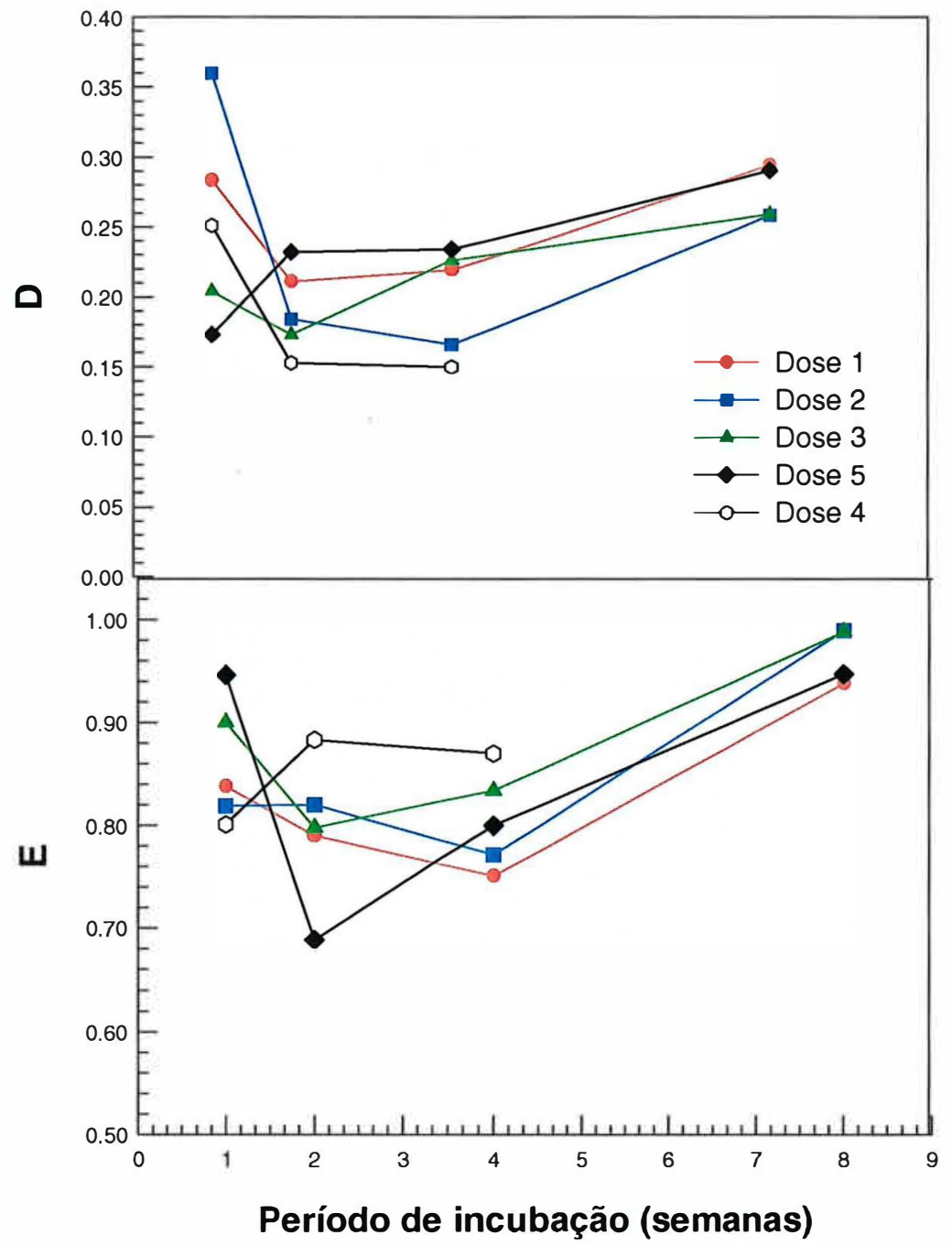

Figura 7 - Índices de diversidade. A, Índice de dominância de Simpson (D); B, Índice de eqüiabilidade $(\mathrm{E})$, de solo argiloso tratado com biossólido da ETE-Franca calculados a partir dos dados de abundância relativa dos amplicons em função do tempo de incubação do solo. Dose 1 , sem adição de biossólido; Dose 2, $6 \mathrm{Mg} \mathrm{ha}^{-1}$; Dose 3, $12 \mathrm{Mg} \mathrm{ha}^{-1}$; Dose 4, $24 \mathrm{Mg} \mathrm{ha}^{-1}$; Dose 5, $48 \mathrm{Mg} \mathrm{ha}^{-1}, \mathrm{~T} 1,1$ semana; T2, 2 semanas; T3, 4 semanas; T4, 8 semanas após a aplicação do biossólido. 
$\mathrm{O}$ índice de diversidade de Shannon-Weaver $(\mathrm{H})$, definido como o somatório de todo os indivíduos presentes na amostra é mostrado na Figura 6. $\mathrm{Na}$ amostra de solo tratada com quantidade de biossólido equivalente a $24 \mathrm{Mg}$ $h^{-1}$ não ocorreu variação significativa até quatro semanas de incubação $(2,6)$, decrescendo em 8 semanas $(1,9)$. Nas amostras tratadas com quantidades de biossólido equivalentes a 6,12 e $48 \mathrm{Mg} \mathrm{ha}^{-1}$ o valor de $\mathrm{H}$ cresceu $(1,6-3,0)$ com o tempo de incubação, decrescendo posteriormente até igualar-se ao controle, após 8 semanas.

O índice de dominância de Simpson (D), definido como o valor provável de indivíduos de mesma espécie na amostra é mostrado na Figura 7. $O$ valor de $D$ para amostra controle foi reduzido $(0,28-0,22)$ após 2 semanas de incubação, recuperando o valor inicial após 8 semanas. A aplicação de biossólido em quantidades equivalentes a 6, 12 e $24 \mathrm{Mg} \mathrm{ha}^{-1}$, em geral, aumentaram o valor de $D$ ao longo do tempo de incubação $(0,17-0,30)$. Após 8 semanas, não há diferenças entre os valores de $D$ em relação à dose de biossólido aplicada. Somente na amostra tratada com $48 \mathrm{Mg} \mathrm{ha}^{-1}$ ocorreu um decréscimo no valor de $D$ entre a primeira e segunda semana de incubação, mantendo-se posteriormente um valor constante.

$O$ índice de eqüitabilidade $(E)$, definido como estimativa da distribuição de indivíduos na amostra é mostrado na Figura 7. Com 1 semana de incubação do solo-biossólido o valor de $E$ foi crescente até a aplicação da dose equivalente a $24 \mathrm{Mg} \mathrm{ha}^{-1}$ de biossólido. Com a aplicação de $48 \mathrm{Mg} \mathrm{ha}^{-1} \mathrm{o}$ valor de $\mathrm{E}$ foi menor que o controle. Após 2 e 4 semanas de incubação, os valores de $\mathrm{E}$ foram crescentes de acordo com o aumento da dose de biossólido. Após 8 semanas de incubação, em geral, não há variação nos valores de $D$ com o aumento da dose de biossólido. 
$\mathrm{Na}$ primeira semana de incubação, não houve diferenças significativas, entre os índices de diversidade comparando amostras de solos tratadas com biossólidos em relação controle. Na segunda semana de incubação, o valor de $\mathrm{S}$ duplicou e $\mathrm{H}$ aumentou com o aumento da dose de biossólido. Após 4 semanas de incubação não houve diferenças entre a amostra de solo tratada com quantidade de biossólido equivalente a $48 \mathrm{Mg} \mathrm{ha}^{-1}$ e o controle sem biossólido. Um decréscimo acentuado foi observado no valor de $S$ quando quantidade de biossólido equivalente a $24 \mathrm{Mg} \mathrm{ha}^{-1}$ foi adicionada ao solo. Com 8 semanas de incubação todos os índices se igualaram ao controle. A aplicação de biossólido ao solo alterou os índices de diversidade em relação ao controle de cada época de amostragem, sugerindo que ocorreram alterações na estrutura da comunidade. $O$ aumento da eqüitabilidade após 8 semanas de incubação sugere que a aplicação do biossólido modificou a estrutura da comunidade de Bacteria como resposta ao distúrbio imposto, porém, este não foi persistente, demonstrando a rápida recuperação do solo ou resiliência do sistema.

Resultados semelhantes foram obtidos por Lopes (dados não publicados), Um aumento no valor de $\mathrm{H}$ na Segunda semana de incubação quando quantidades equivalentes a 12, 24 e $48 \mathrm{Mg} \mathrm{ha}^{-1}$ foram adicionadas ao solo, as diferenças significativas indicaram uma alteração: na estrutura da comunidade em função da menor disponibilidade de C-orgânico. Após 16 semanas de incubação, além do decréscimo no carbono orgânico adicionado foi detectada a diminuição da resiliência do sistema solo.

Da mesma forma, Banerjee et al. (1997) estudaram a variação na biomassa e diversidade funcional das populações microbianas de um solo tratado com biossólido com baixa contaminação de metais pesados, demonstrando que a aplicação de biossólido resultou em redução da diversidade microbiana, porém, com igual ou maior biomassa e atividade 
enzimática, não afetando os processos bioquímicos de mineralização de $\mathrm{N}, \mathrm{P}$ e S. Stephen et al. (1999) avaliaram a sobrevivência de cinco espécies de bactérias por PCR-DGGE. Os resultados mostraram que com a adição dos metais Cs, Cd, Co, Sr as abundâncias relativas de algumas espécies decresceu logo após a inoculação, porém, outras espécies permaneceram constantes nas 8 semanas de incubação, em todos tratamentos. Contudo, algumas espécies foram dose-dependente, diminuindo rapidamente em solo não-contaminado, demonstrando a presença de espécies tolerantes a metais.

Por outro lado, Pannanen et al. (1996) também encontraram efeitos nos perfis de ácidos graxos fosfolipídicos que não se correlacionam diretamente com a poluição por metais pesados. Neste caso, as mudanças encontradas nos perfis de ácidos graxos fosfolipídicos não foram atribuídas às mudanças nos níveis de tolerância da comunidade microbiana. Da mesma forma, Griffiths et al. (2000) encontraram menor biodiversidade e conseqüente redução nas taxas de nitrificação com decréscimo nos processos de decomposição. Contudo, quando analisadas as funções individuais, estas demonstraram uma relação direta entre a biodiversidade e estabilidade destes solos com biodiversidade reduzida, ou seja, com o declínio da diversidade o solo foi menos resistente e resiliente às perturbações ambientais. 


\subsection{Experimento 2: Alterações da estrutura das comunidades $e$ diversidade genética de Bacteria em solos cultivados com milho (Zea mays), após a aplicação de biossólidos}

\subsubsection{Análises químicas e físicas dos sølos e biossólidos utilizados}

Os dois solos e biossólidos foram analisados para determinação das suas características químicas e físicas. Os resultados das análises podem ser vistos nas Tabelas 6 e 7, respectivamente. Dois tipos de solos foram utilizados: argiloso e arenoso. Os dois solos apresentam pH abaixo de 5,0 e concentração de matéria orgânica semelhante, no entanto, em solo argiloso, a CTC e o conteúdo de argila têm valores mais elevados que no solo arenoso. Estas características são importantes pois podem interferir na disponibilidade de metais pesados. Além disso, a estrutura diferenciada de cada solo pode conferir menor capacidade de retenção de água, nutriente e metais pesados (Obbard, 2000). Em vista disso deve ocorrer maior biodisponibilidade de metais pesados em solo arenoso, pois há diferenças em relação aos sítios de adesão, biomassa e diversidade microbiana (Øvreås \& Torsvik, 1998). Estes fatores tornam-se importante para o crescimento de microrganismos, desenvolvimento das raízes das plantas e distribuição de nutrientes no solo.

As análises dos biossólidos, detectaram diferenças significativas na composição química dos biossólidos utilizados no experimento. No biossólido da ETE-Franca os valores mais elevados na concentração de metais foram para Żn e $\mathrm{Cr}$, ou seja, baixa contaminação e $\mathrm{pH} 7,8$, um pouco acima da neutralidade. $\mathrm{O}$ biossólido da ETE-Baruieri apresentou valores elevados para todos os metais, ou seja, alta concentração de metais. Com um pH 10,8, os metais encontram-se nas formas menos solúveis. Este $\mathrm{pH}$ elevado do biossólido da ETE-Barueri se justifica pelo seu tratamento com $\mathrm{CaO}$, que apresenta características fortemente alcalinas, no processo de estabilização. 
Tabela 6. Características químicas e físicas dos solos utilizados no experimento.

\begin{tabular}{|c|c|c|c|}
\hline \multirow[b]{2}{*}{ ATRIBUTOS } & & \multicolumn{2}{|c|}{$\therefore \quad$ SOLOS } \\
\hline & & $\begin{array}{l}\text { NITOSSOLO } \\
\text { VERMELHO } \\
\text { Eutroférrico típico }\end{array}$ & $\begin{array}{c}\text { NEOSSOLO } \\
\text { QUARTIZARÊNICO } \\
\text { Órtico típico }\end{array}$ \\
\hline $\mathrm{pH}\left(\mathrm{CaCl}_{2} 0,01 \mathrm{M}\right)$ & $\because$ & 5,4 & 3,5 \\
\hline Matéria orgânica $\left(\mathrm{g} \mathrm{dm}^{-3}\right)$ & .. & 19,0 & 14,0 \\
\hline$P$ resina $\left(\mathrm{mmol}_{\mathrm{c}} \mathrm{dm}^{-3}\right)$. & $\therefore$ & 23,0 & 3,0 \\
\hline $\mathrm{K}^{+}\left(\mathrm{mmol}_{\mathrm{c}} \mathrm{dm}^{-3}\right)$ & $\because$ & 6,4 & 0,4 \\
\hline $\mathrm{Ca}^{2+}\left(\mathrm{mmol}_{\mathrm{c}} \mathrm{dm}^{-3}\right)$ & & 57,0 & 1,0 \\
\hline $\mathrm{Mg}^{2+}\left(\mathrm{mmol}_{\mathrm{c}} \mathrm{dm}^{-3}\right)$ & & $.12,0$ & 1,0 \\
\hline $\mathrm{H}+\mathrm{Al}\left(\mathrm{mmol}_{\mathrm{c}} \mathrm{dm}^{-3}\right)$ & & 52,0 & 31,0 \\
\hline$S\left(\mathrm{mmol}_{\mathrm{c}} \mathrm{dm}^{-3}\right)$ & & 40,0 & 7,0 \\
\hline CTC $\left(\mathrm{mmol}_{\mathrm{C}} \mathrm{dm}^{-3}\right)$ & & 101,7 & 54,4 \\
\hline$V(\%)$ & & 70,0 & 4,0 \\
\hline Areia muito grossa $(1-2 \mathrm{~mm})(\%)$ & & 1,0 & 1,0 \\
\hline Areia grossa $(0,5-1 \mathrm{~mm})(\%)$ & & 1,0 & 5,0 \\
\hline Areia média $(0,25-0,5 \mathrm{~mm})(\%)$ & & 5,0 & 26,0 \\
\hline Areia fina $(0,1-0,25 \mathrm{~mm})(\%)$ & & $\therefore 15,0$ & 46,0 \\
\hline Areia muito fina $(0,05-0,1 \mathrm{~mm})(\%)$ & & 4,0 & 4,0 \\
\hline Areia total $(0.05-2 \mathrm{~mm})(\%)$ & & 26,0 & 82,0 \\
\hline Silte $(0,002-0,05 \mathrm{~mm})(\%)$ & & 16,0 & 4,0 \\
\hline Argila dispersa em água $(<0,002)$ & & 43,0 & 6,0 \\
\hline Argila total $(<0,002 \mathrm{~mm})(\%)$ & & 58,0 & 14,0 \\
\hline
\end{tabular}


Tabela 7. Carạcterísticas químicas dos biossólidos da ETE-Franca e ETEBarueri, utilizados no experimento.

\begin{tabular}{|c|c|c|}
\hline \multirow[t]{2}{*}{ ATRIBUTO } & \multicolumn{2}{|c|}{ BIOSSOLLIDO } \\
\hline & ETE-Franca & ETE-Barueri \\
\hline $\mathrm{pH}\left(\mathrm{CaCl}_{2} 0,01 \mathrm{M}\right)$ & 7,8 & 10,8 \\
\hline $\mathrm{H}_{2} \mathrm{O}\left(\mathrm{g} \mathrm{kg}^{-1}\right)$ & 842,5 & 733,9 \\
\hline Carbono total $\left(\mathrm{g} \mathrm{kg}^{-1}\right)$ & 414,6 & 216,1 \\
\hline Carbono Orgânico $\left(\mathrm{g} \mathrm{kg}^{-1}\right)$ & 410,8 & 157,8 \\
\hline Resíduo Mineral total $\left(\mathrm{g} \mathrm{kg}^{-1}\right)$ & 254,0 & 611,0 \\
\hline Resíduo Mineral Insolúvel $\left(\mathrm{g} \mathrm{kg}^{-1}\right)$ & 94,0 & 134,5 \\
\hline Resíduo Mineral Solúvel $\left(\mathrm{g} \mathrm{kg}^{-1}\right)$ & 160,0 & 476,5 \\
\hline Nitrogênio total $\left(\mathrm{g} \mathrm{kg}^{-1}\right)$ & 56,5 & 22,5 \\
\hline Fósforo total $\left(\mathrm{g} \mathrm{kg}^{-1}\right)$ & 13,0 & 19,3 \\
\hline Potássio total $\left(\mathrm{g} \mathrm{kg}^{-1}\right)$ & 1,0 & 1,2 \\
\hline Cálcio total $\left(\mathrm{g} \mathrm{kg}^{-1}\right)$ & 14,0 & 150,3 \\
\hline Sódio total $\left(\mathrm{g} \mathrm{kg}^{-1}\right)$ & 635,0 & 932,0 \\
\hline Magnésio total $\left(\mathrm{g} \mathrm{kg}^{-1}\right)$ & 1,9 & 3,4 \\
\hline Enxofre total $\left(\mathrm{g} \mathrm{kg}^{-1}\right)$ & 4,4 & 8,3 \\
\hline Zinco total $\left(\mathrm{mg} \mathrm{kg}^{-1}\right)$ & 1359,0 & 2123,0 \\
\hline Ferro total $\left(\mathrm{mg} \mathrm{kg}^{-1}\right)$ & 24019,0 & 38298,0 \\
\hline Cobre total (mg kg $\left.{ }^{-1}\right)$ & 197,0 & 507,0 \\
\hline Manganês total $\left(\mathrm{mg} \mathrm{kg}^{-1}\right)$ & 190,0 & 229,0 \\
\hline Crômio total $\left(\mathrm{mg} \mathrm{kg}^{-1}\right)$ & 949,0 & 501,0 \\
\hline Níquel total $\left(\mathrm{mg} \mathrm{kg}^{-1}\right)$ & 47,0 & 242,0 \\
\hline Relação C-orgânico/N-total & 7,0 & 10,0 \\
\hline
\end{tabular}

Os dados expressam a concentração com base na matéria seca a $65^{\circ} \mathrm{C}$. 
Durante a decomposição do resíduo orgânico, a maior parte do C é mineralizado a $\mathrm{CO}_{2}, \mathrm{~N}, \mathrm{P}$ e $\mathrm{S}$ além de outros compostos menores. O processo de oxidação do carbono e biossíntese de novos materiais citoplasmáticos e células microbianas (biomassa), ocorre simultaneamente com a liberação de substâncias nutritivas contidas no resíduo em decomposição e a imobilização destes nutrientes ocorre para atender a demanda nutricional da microbiota. As duas vias deste processo são importantes para avaliação das condições de fertilidade do solo. Porém, a formação de complexos entre micronutrientes e a matéria orgânica pode resultar na deficiência de elementos como $\mathrm{Cu}$ e $\mathrm{Zn}$, porque, ficam retidos nos compostos orgânicos (Priha et al., 2001).

Frostegård et al. (1993), observaram pequenas diferenças entre a toxicidade de metais nos dois tipos de solo, arenoso e argiloso, embora as diferenças pouco significativas no conteúdo de matéria orgânica. Uma razão

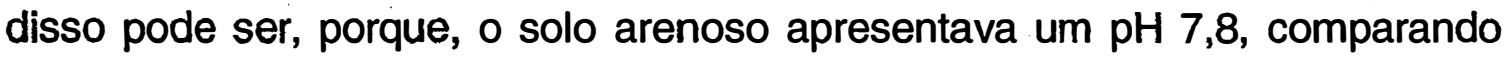
com 4,5 do solo de floresta. Diversos estudos feitos preliminarmente em laboratório, mostraram que $\mathrm{opH}$ interfere na toxicidade de metais, que geralmente é maior em pH baixo. As quantidades máximas de biossólidos e seus limites para aplicação em solos agrícolas podem ser vistos na Tabela 8.

Tabela 8. Taxa anual máxima de metais permitida pela Norma P4.230 da CETESB (Estado de São Paulo, 1999) e taxa de metais aplicados no solo, de acordo com as dose definidas.

\begin{tabular}{|c|c|c|c|c|}
\hline \multirow[t]{2}{*}{ Metal } & \multirow[t]{2}{*}{$\begin{array}{c}\text { Taxa máxima anual } \\
\left(\mathrm{Kg} \mathrm{ha}^{-1}\right)\end{array}$} & \multirow[t]{2}{*}{$\begin{array}{l}\text { Concentração máxima } \\
\text { premitida no biossólido } \\
\left(\mathrm{mg} \mathrm{kg}^{-1}\right)\end{array}$} & \multicolumn{2}{|c|}{$\begin{array}{c}\text { Quantidade máxima } \\
\text { permitida de biossólido } \\
\left(\mathrm{Mg} \mathrm{ha}^{-1}\right)\end{array}$} \\
\hline & & & Franca & Barueri \\
\hline $\mathrm{Cu}$ & 75 & 4300 & 392,7 & 154,0 \\
\hline $\mathrm{Ni}$ & 21 & 420 & 446,8 & 86,8 \\
\hline Cd & 1,9 & 85 & 158,1 & 299,4 \\
\hline $\mathrm{Zn}$ & 140 & 7500 & 47,0 & 84,4 \\
\hline
\end{tabular}


O material orgânico e inorgânico resultante da decomposição da matéria orgânica, se transforma em formas inorgânicas disponíveis para as plantas, sendo em parte assimilada pela biomassa ou estabilizada a formas orgânicas recalcitrantes. $\mathrm{O}$ pH e a textura dos solos contribuem para a redução da toxicidade causada por metais em alta concentração (McGrath et al., 1995).

\subsubsection{Extração de DNA total dos solos}

O DNA total dos solos foi extraído imediatamente após a coleta das amostras usando o kit Fast DNA (Bio 101) para extração. Este kit utiliza um método de extração direta de DNA. Métodos de extração direta têm sido descritos como mais eficazes para extração de DNA de todas as bactérias, sejam elas classificadas como positivas ou negativas pelo método de Gram (Tsai \& Olsen, 1992; Kozdrój \& van Elsas, 2001). O DNA obtido de ambos os solos foi purificado com o mesmo kit, através da precipitação de proteínas e ligação do DNA em sílica ativada com tiocianato de guanidina. Os resultados indicam que à metodologia utilizada para extração e purificação do DNA, foi adequada para os dois tipos de solo. Isso pode ser observado pois o DNA obtido apresenta alta massa molecular e baixo fracionamento (Figura 8).

A qualidade do DNA total extraído foi estimada pela análise da relação entre as absorbâncias da solução de DNA a 260 e $280 \mathrm{~nm}\left(\mathrm{~A}_{260} / \mathrm{A}_{280}\right)$, cujo resultado fornece informações sobre de contaminação por proteínas. Valores de $A_{260} / A_{280}$ entre 1,8 e 2,0 denotam DNA de alta qualidade. Os resultados obtidos indicam que o método de extração de DNA utilizado permite uma remoção eficiente das proteínas das amostras de DNA, visto que, em média a relação $A_{260} / A_{280}$ das amostras tratadas com o biossólido de Franca foi de 1,73 e 2,05, 30 e 60 dias, respectivamente. 
Solo

Biossólido

Dose

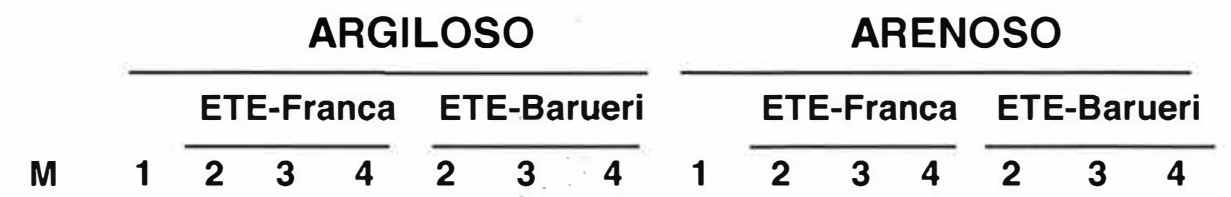

pb

2000

1200

800

400

200

100

Figura 8 - DNA total extraído das amostras de solo argiloso e arenoso, tratadas com biossólido da ETE-Franca ou ETE-Barueri. M, marcador de massa; Dose 1, controle sem aplicação de biossólido; ETE-Franca: Dose 2, $6 \mathrm{Mg} \mathrm{ha}^{-1}$; Dose 3, $24 \mathrm{Mg} \mathrm{ha}^{-1}$; Dose 4, $96 \mathrm{Mg} \mathrm{ha}^{-1}$; ETEBarueri: Dose 2, $31 \mathrm{Mg} \mathrm{ha}^{-1}$; Dose 3, $62 \mathrm{Mg} \mathrm{ha}^{-1}$; Dose 4, $124 \mathrm{Mg} \mathrm{ha}^{-1}$. 
Para as amostras tratadas com o biossólido da ETE-Barueri, em média a relação $A_{260} / A_{280}$ foi de 1,87 e 2,08, 30 e 60 dias, respectivamente (Tabela 9). A presença de ácidos húmicos foi estimada pela relação entre as absorbâncias da solução de DNA a 260 e $230 \mathrm{~nm}\left(\mathrm{~A}_{260} / \mathrm{A}_{230}\right)$. Em soluções com baixa concentração de ácidos húmicos, essa relação deve ser maior do que 2,0. Os dados obtidos sugerem que a concentração de ácidos húmicos nas amostras é alta, indicando que o método utilizado para extração de DNA 16S apresenta baixa eficiência na remoção destes. No entanto, a presença de ácidos húmicos nas amostras de DNA não interferiu na amplificação do rDNA $16 S$ por PCR. A relação $A_{260} / A_{230}$ das amostras tratadas com o biossólido de Franca foi de 0,12 e 0,04, 30 e 60 dias, respectivamente. Para as amostras tratadas com o biossólido da ETE-Barueri, em média a relação $A_{260} / A_{230}$ foi de 0,09 e 0,26, 30 e 60 dias, respectivamente (Tabela 9).

\subsubsection{Estrutura da comunidade de Bacteria}

Os amplicons presentes nos géis de poliacrilamida com gradiente desnaturante de amostras de solo, argiloso e arenoso, tratadas com diferentes doses dos biossólidos da ETE-Franca e ETE-Barueri, estão distribuídos como pode ser observado na Figura 10. Sua representação esquemática pode ser vista na Figura 11. O total de amplicons detectados, após 30 dias do plantio do milho, foi de 31 amplicons distribuídos entre os tratamentos. Cerca de $12,9 \%$ dos amplicons foram observados em todas as amostras, cujos Rfs são: 0,344; 0,$377 ; 0,693$ e 0,728 . Somente $9,6 \%$ dos amplicons estão presentes preferencialmente nas amostras que receberam o biossólido da ETE-Barueri, cujos Rfs são: 0,355; 0,635 e 0,649. Os amplicons com Rfs 0,418 e 0,672 $(6,5 \%)$, só não foram detectados nas amostras de solo arenoso tratado com quantidade equivalente a $62 \mathrm{Mg} \mathrm{ha}^{-1}$ do biossólido da ETE-Barueri. 


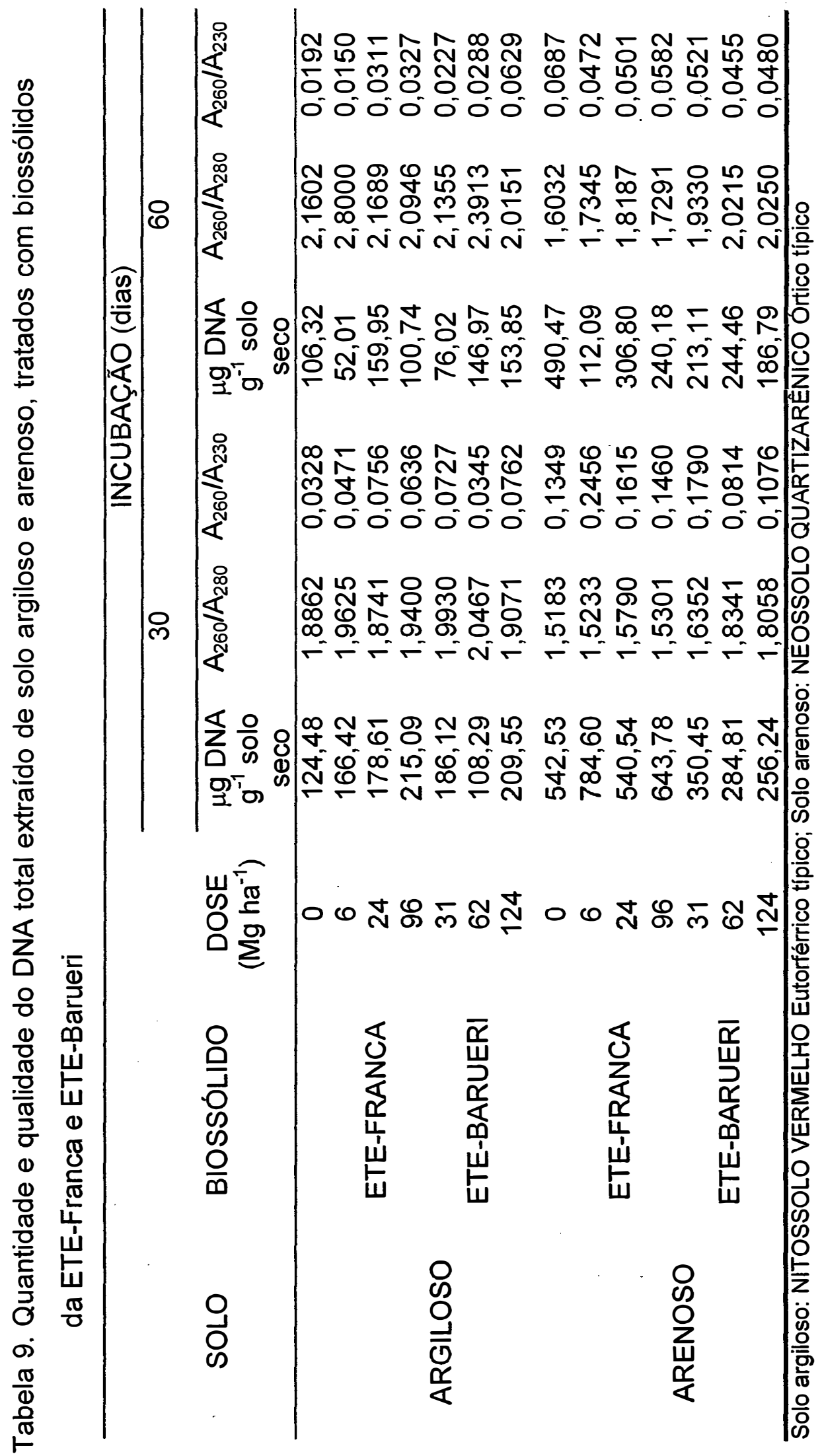




\section{Solo \\ Biosólido}

Dose

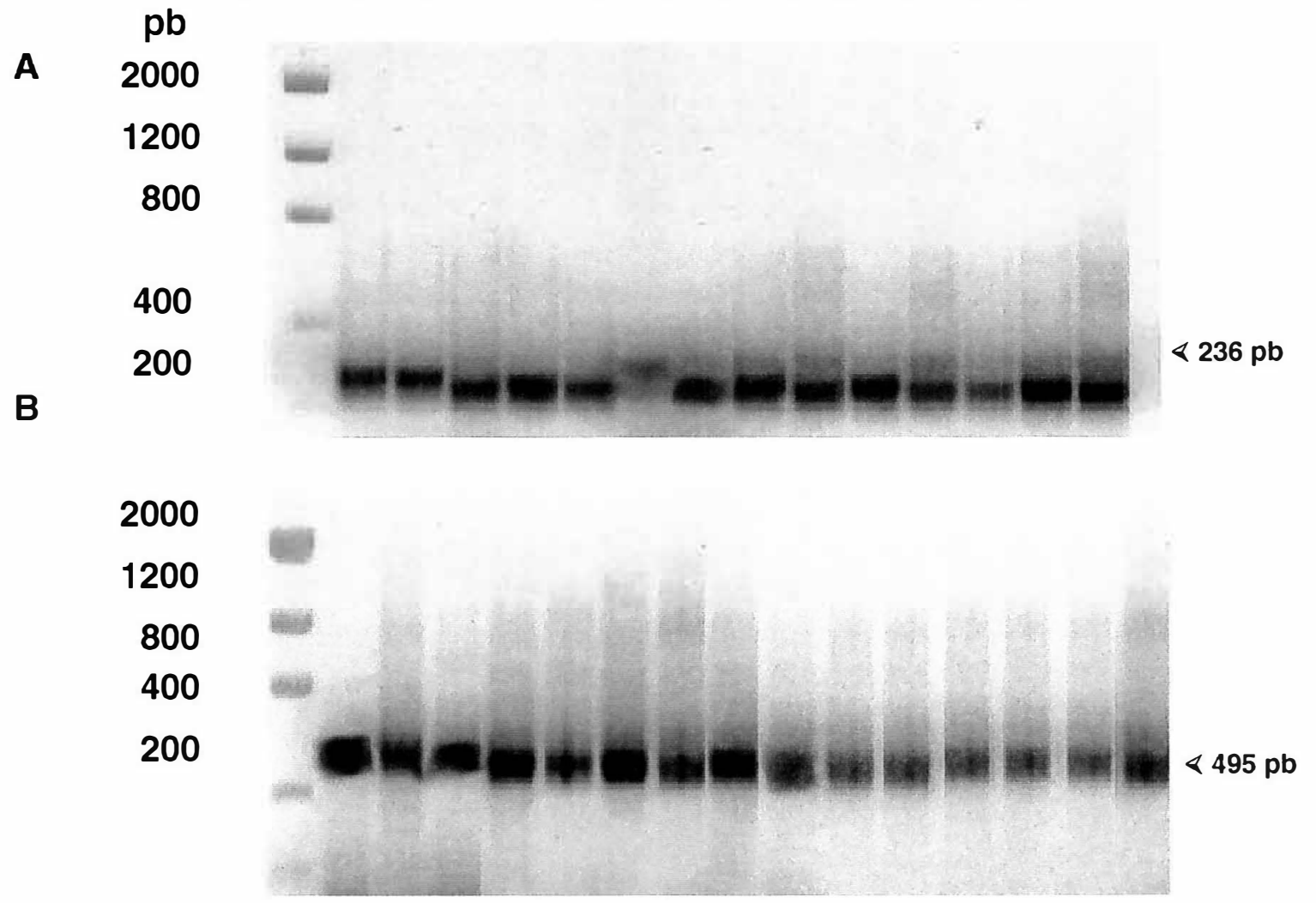

Figura 9 - Amplicons sintetizados por PCR do rDNA 16S de Bacteria de solo argiloso e arenoso tratado com biossólido da ETE-Franca ou ETE-Barueri. M, marcador de massa molecular; Dose 1, sem adição de biossólido; ETEFranca: Dose 2, $6 \mathrm{Mg} \mathrm{ha}^{-1}$; Dose 3, $24 \mathrm{Mg} \mathrm{ha}^{-1}$; Dose 4, $96 \mathrm{Mg} \mathrm{ha}^{-1}$, ETEBarueri: Dose 2, $31 \mathrm{Mg} \mathrm{ha}^{-1}$; Dose 3, $62 \mathrm{Mg} \mathrm{ha}^{-1}$; Dose 4, $124 \mathrm{Mg} \mathrm{ha}^{-1}$. A, região $\mathrm{V} 3$; $\mathrm{B}$, região $\mathrm{V} 1-\mathrm{V} 3$. 
Somente na amostra de solo arenoso tratado com quantidade equivalente a 6 $\mathrm{Mg} \mathrm{ha}^{-1}$ do biossólido da ETE-Franca foram identificados os amplicons de Rfs 0,246 e 0,256. Após 60 dias do plantio do milho, uma nova avaliação foi feita (Figura 12). A representação esquemática pode ser vista na Figura 13. Neste caso, foram observados 26 amplicons. Somente o amplicon com Rf 0,483 $(3,8 \%)$ está presente em todas as amostras. Os solos sem biossólido e o tratamento com quantidade equivalente a $6 \mathrm{Mg} \mathrm{ha}^{-1}$ do biossólido da ETEFranca, em solo argiloso, apresentam um amplicon com Rf de 0,512 (3,8\%). O amplicon com Rf 0,451 (3,8\%) está presente, preferencialmente nas amostras que receberam as doses mais altas do biossólido da ETE-Franca, independente do tipo de solo. Os amplicons de Rfs 0,349 e 0,357 (7,7\%); foram observados apenas na amostra de solo arenoso tratado com quantidade equivalente a $6 \mathrm{Mg}$ $\mathrm{ha}^{-1}$ do biossólido da ETE-Franca, enquanto que o amplicon com Rf 0,348 $(3,8 \%)$ foi detectado preferencialmente em solo arenoso independente do tipo de biossólido aplicado.

Da mesma forma, Kozdrój \& van Elsas (2001) analisaram solos por PCR-DGGE e metil ésteres de ácidos graxos. As diferenças da estrutura das comunidades foram mais visíveis após a diluição do DNA, indicando que as populações menos dominantes foram afetadas por metais pesados. Além disso, o conteúdo de matéria orgânica, tipo de solo a cultura foram fatores de alteração na composição da comunidade bacteriana, visto que diferentes populações podem estar envolvidas nos efeitos da poluição por metais pesados, resultando em alterações na estrutura da comunidade. Contudo, cada solo pode ser caracterizado por uma comunidade bacteriana específica, no entanto, estas diferenças podem estar relacionadas às populações menos numerosas cujos amplicons são menos visíveis (Gelsomino et al., 1999). 


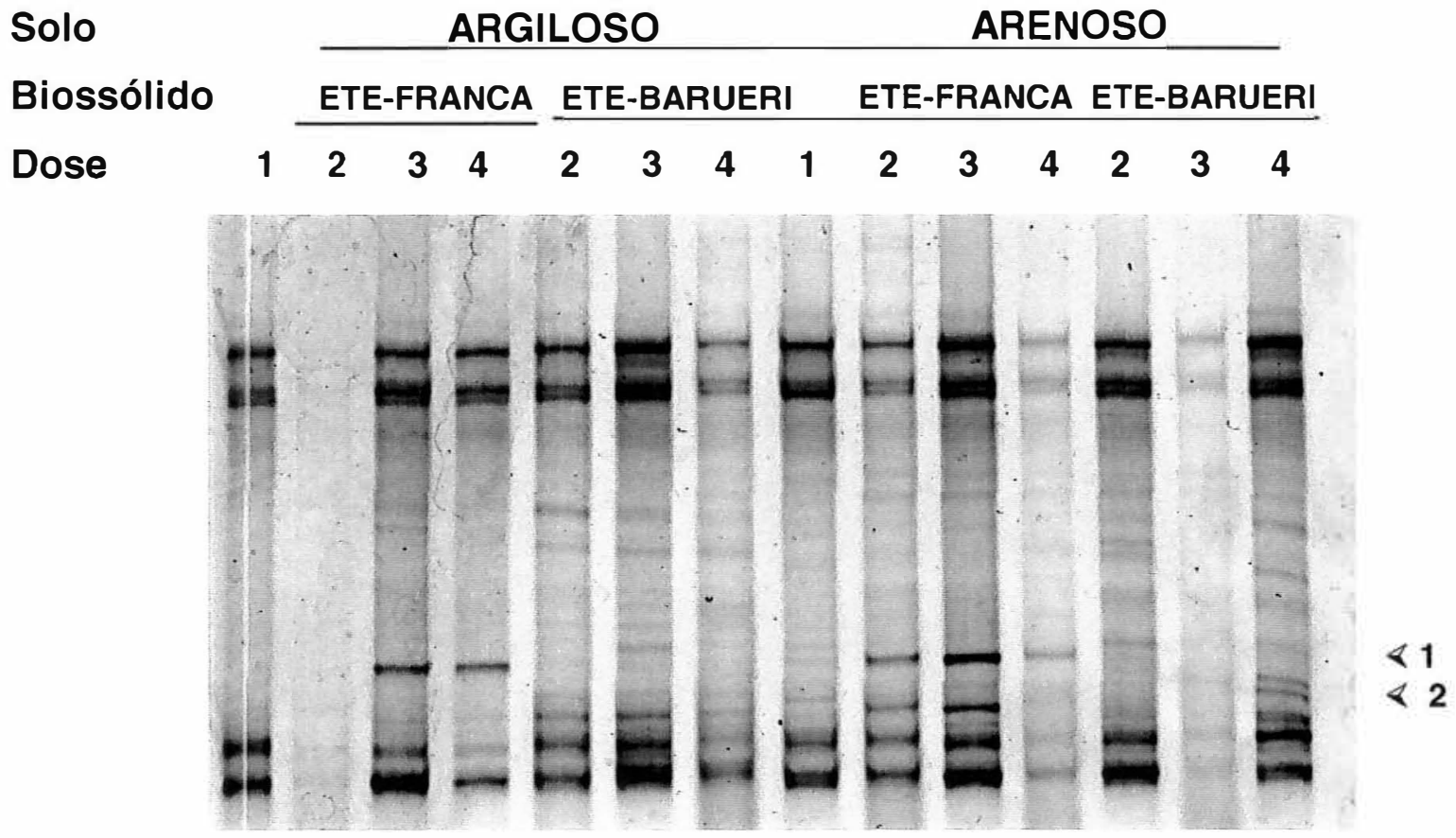

Figura 10 - Amplicons da região V3 do rDNA 165 das comunidades de Bacteria de solo argiloso ou arenoso tratado com biossólidos da ETE-Franca ou ETE-Barueri. Os amplicons foram separados em gel de poliacrilamida $8 \%$, com gradiente desnaturante (15-55\%). O DNA foi visualizado por coloração com SYBR Green I. Dose 1, sem aplicação de biossólido; ETE-Franca: Dose 2, $6 \mathrm{Mg} \mathrm{ha}^{-1}$; Dose 3, $24 \mathrm{Mg} \mathrm{ha}^{-1}$; Dose 4, $96 \mathrm{Mg} \mathrm{ha}^{-1}$; ETE-Barueri: Dose 2, $31 \mathrm{Mg} \mathrm{ha}^{-1}$; Dose 3, $62 \mathrm{Mg}$ ha $^{-1}$; Dose 4, $124 \mathrm{Mg} \mathrm{ha}^{-1}$. Amostras coletadas após 30 dias do plantio do milho. As setas indicam os amplicons seqüenciados. 


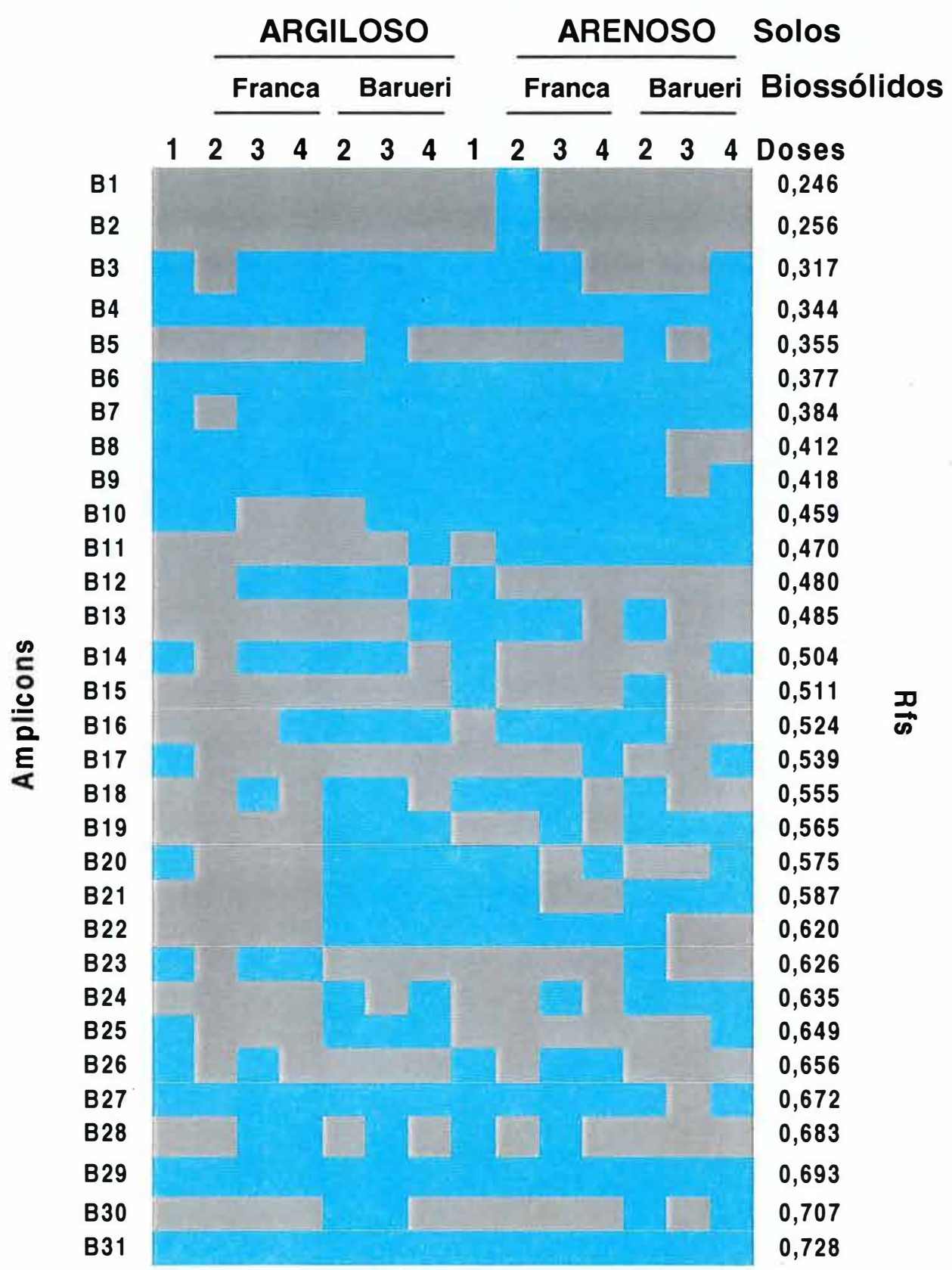

Figura 11 - Diagrama representando os amplicons da região V3 do rDNA 165 das comunidades de Bacteria de solo argiloso e arenoso tratados com biossólidos da ETE-Franca ou ETEBarueri. Dose 1, sem adição de biossólido; ETE-Franca: Dose 2, $6 \mathrm{Mg} \mathrm{ha}^{-1}$; Dose 3, $24 \mathrm{Mg} \mathrm{ha}^{-1}$; Dose 4, $96 \mathrm{Mg} \mathrm{ha}^{-1}$; ETE-Barueri: Dose 2, $31 \mathrm{Mg} \mathrm{ha}^{-1}$; Dose 3, $62 \mathrm{Mg} \mathrm{ha}^{-1}$; Dose 4, $124 \mathrm{Mg} \mathrm{ha}^{-1}$. Amostras coletadas após 30 dias do plantio do milho. 
Microrganismos do solo influenciam a disponibilidade de metais e nutrientes direta ou indiretamente. Um efeito direto é a degradação da matéria orgânica e subsequente liberação dos nutrientes. Os nutrientes não usados na construção de novas células e processos de manutenção são disponibilizados para as plantas. A biomassa microbiana também é uma fração relativamente lábil da matéria orgânica do solo. Os nutrientes da célula podem também estar disponíveis com a morte da célula microbiana, sendo então atacados por outros microrganismos. Os efeitos diretos são resultantes da interação de subprodutos microbianos com os constituintes do solo (Altieri, 1999). A excreção de diferentes compostos orgânicos dos pêlos radiculares e células epidérmicas são os fatores responsáveis pela estimulação de microrganismos na rizosfera. Os compostos excretados são componentes dos exsudatos, cuja função, no fluxo de carbono é fundamental para o solo, um processo chamado de rizodisposição. $O$ efeito da rizodisposição mostra que uma mistura de açúcares, ácidos orgânicos e aminoácidos são adicionados a solos poluídos com metais (Baudoin et al., 2001).

Griffiths et al. (2001) analisando indicadores potenciais de distúrbios do solo mostraram que a cinética de mineralização do substrato foi significativamente estimulada pela poluição por hidrocarboneto, diferindo do controle. A estabilidade funcional forneceu dados quantitativos sobre a resistência do solo ao distúrbio imposto, diferenciando os tratamentos. Macnaughton et al. (1999) analisaram a estrutura da comunidade de bactérias em solos, por PCR-DGGE e análise de ácidos graxos de fosfolipídios. O aparecimento de quatro amplicons entre 1 e 8 semanas, após o tratamento dos solos com Sr, Co, Cs, foi observado caracterizando as alterações na estrutura da comunidade. 
Solo ARGILOSO ARENOSO

Biossólido Dose

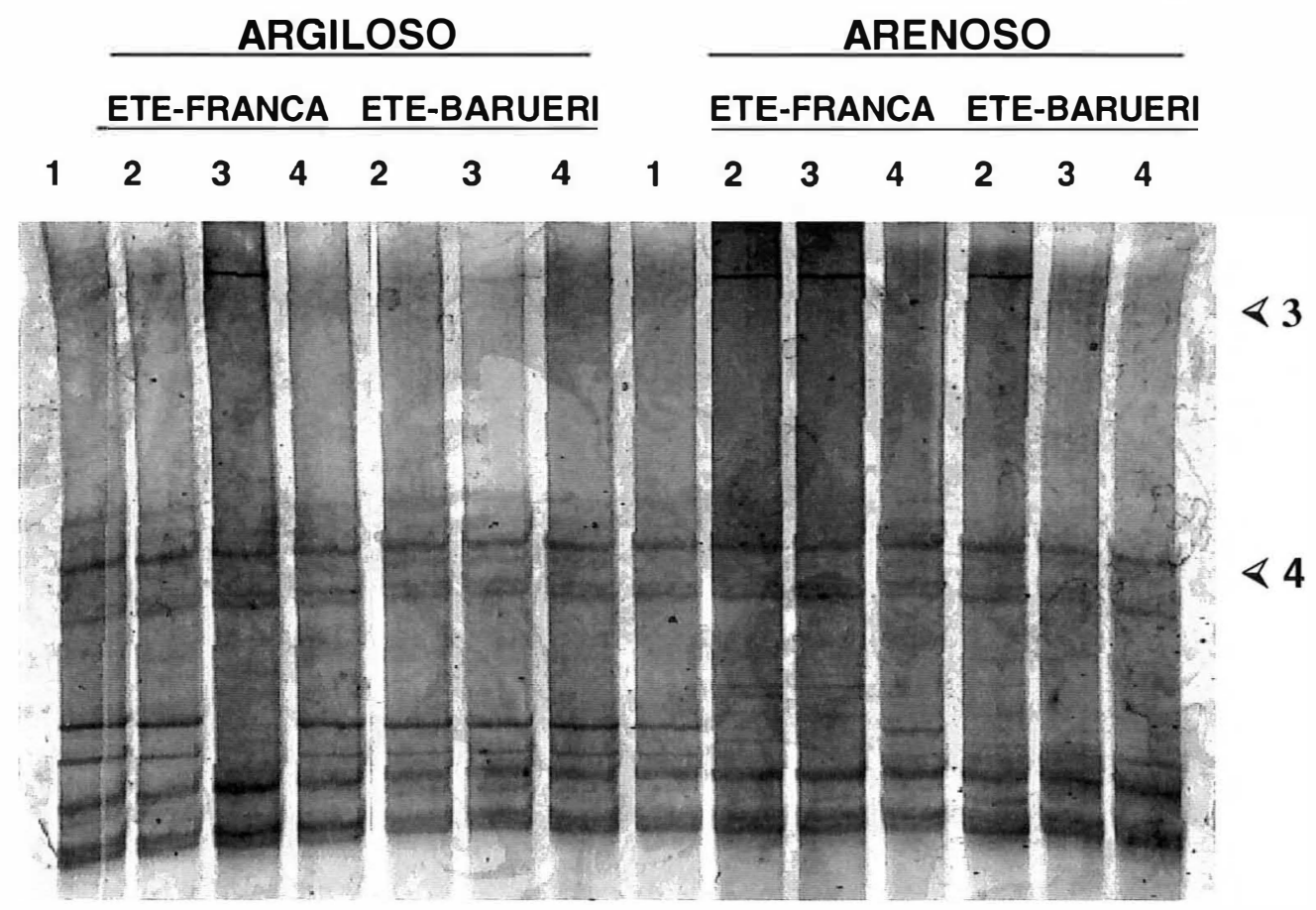

Figura 12 - Amplicons da região V3 do rDNA 16S das comunidades de Bacteria de solo argiloso ou arenoso tratado com biossólidos da ETE-Franca ou ETE-Barueri. Os amplicons foram separados em gel de poliacrilamida $8 \%$, com gradiente desnaturante (15-55\%). O DNA foi visualizado por coloração com SYBR Green I. Dose 1, sem aplicação de biossólido; ETE-Franca: Dose 2, $6 \mathrm{Mg} \mathrm{ha}^{-1}$; Dose 3, $24 \mathrm{Mg} \mathrm{ha}^{-1}$; Dose 4, $96 \mathrm{Mg} \mathrm{ha}^{-1}$; ETE-Barueri: Dose 2, 31 $\mathrm{Mg} \mathrm{ha}^{-1}$; Dose 3, $62 \mathrm{Mg} \mathrm{ha}^{-1}$; Dose 4, $124 \mathrm{Mg} \mathrm{ha}^{-1}$. Amostras coletadas após 60 dias do plantio do milho. As setas indicam os amplicons seqüenciados. 


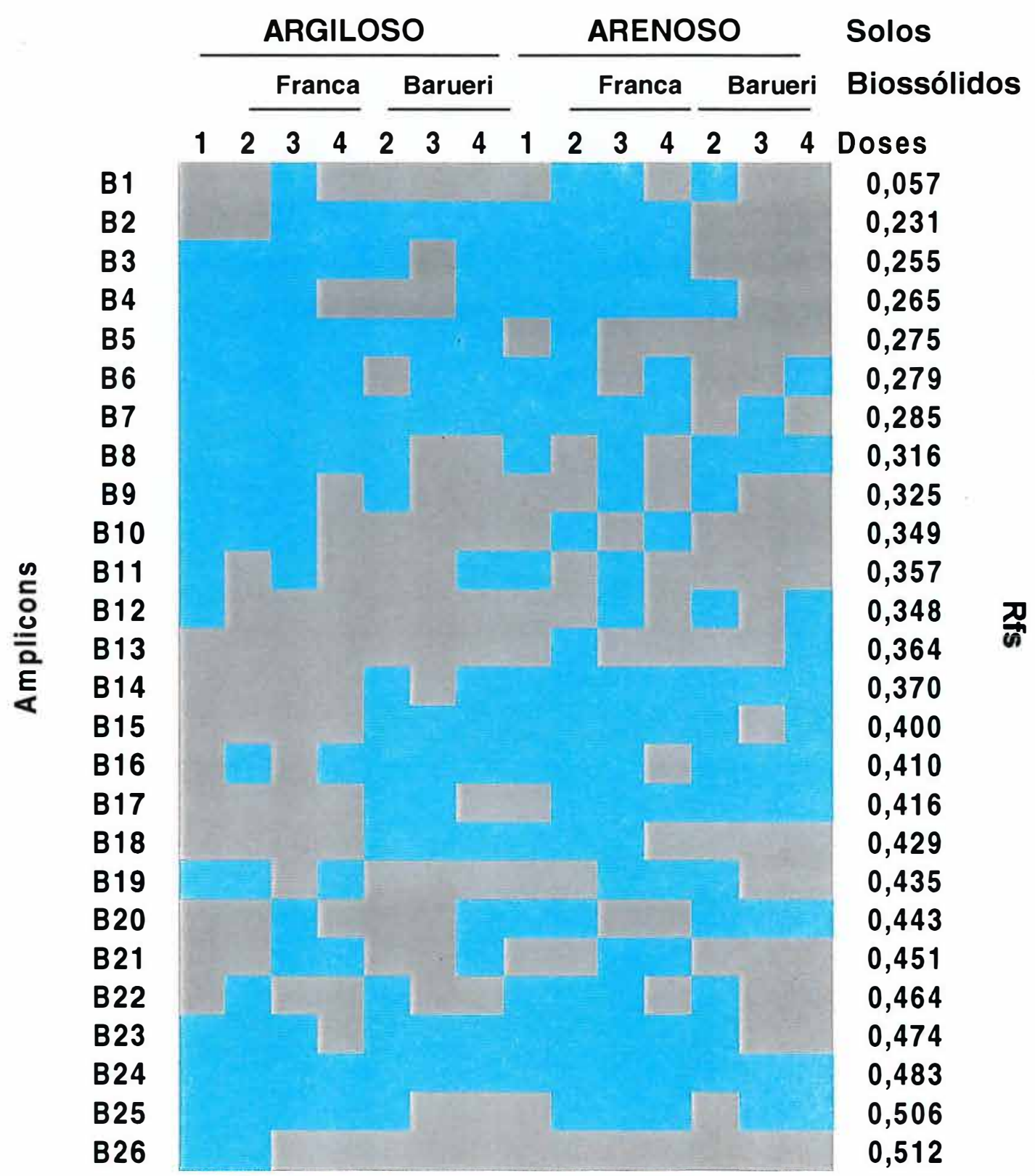

Figura 13 - Diagrama representando os amplicons da região V3 do rDNA $16 \mathrm{~S}$ das comunidades de Bacteria de solo argiloso e arenoso tratados com biossólidos da ETE-Franca ou ETE-Barueri. Dose 1, sem adição de biossólido; ETE-Franca: Dose 2, $6 \mathrm{Mg} \mathrm{ha}^{-1}$; Dose 3, $24 \mathrm{Mg} \mathrm{ha}^{-1}$; Dose 4, $96 \mathrm{Mg} \mathrm{ha}^{-1}$; ETE-Barueri: Dose 2, $31 \mathrm{Mg} \mathrm{ha}^{-1}$; Dose 3, $62 \mathrm{Mg} \mathrm{ha}^{-1}$; Dose 4, $124 \mathrm{Mg} \mathrm{ha}^{-1}$. Amostras coletadas após 60 dias do plantio do milho. 
Por outro lado, Sitaula et al. (1999) determinaram a distribuições da atividade de metais em três sistemas: sobrenadante, bactérias e pélete de solos com e sem esterco. Os resultados mostraram que o solo tratado com esterco tem maior atividade de $\mathrm{Cd}$ e $\mathrm{Zn}$ na fração bacteriana que no solo sem esterco. Segundo os autores, a maior comunidade bacteriana $\mathrm{em}$ solo com esterco, pode contribuir para uma maior quantidade de metais associados. Bååth et al. (1998), com o resultado da análise de componente principal dos padrões de ácidos graxos fosfolipídicos da comunidade microbiana do solo, mostraram que a aplicação de altas doses de $\mathrm{Cu}$ afeta a comunidade microbiana alterando sua estrutura, induzindo ou reduzindo do número de espécies, conforme o conteúdo de umidade do solo.

A similaridade entre as estruturas das comunidades de Bacteria, foi usada para avaliar as alterações ocorridas nos solos tratados com biossólido, calculando-se uma matriz de similaridade Os resultados demonstram para ambos os solos, 30 dias após o plantio de milho, as comunidades de Bacteria dos solos que receberam biossólidos da ETE-Franca eram mais semelhantes ao controle sem biossólido do que aqueles que receberam biossólido da ETEBarueri (Tabela 10). Em média, a similaridade da comunidade de Bacteria do solo argiloso tratado com biossólido da ETE-Franca foi de aproximadamente $74,2 \%$ em relação a comunidade de Bacteria do solo sem biossólido. Já, as comunidades do solo argiloso tratado com biossólido da ETE-Barueri apresentaram aproximadamente $62,4 \%$ de similaridade com o controle sem biossólido. Em solo arenoso tratado com biossólido da ETE-Franca, as comunidades de Bacteria apresentaram aproximadamente $65,5 \%$ de similaridade com a comunidade de Bacteria do solo sem biossólido. Já, as comunidades do solo arenoso tratado com biossólido da ETE-Barueri apresentaram aproximadamente $53 \%$ de similaridade com o controle sem biossólidos. As comunidades de Bacteria do solo argiloso tratado com 
biossólido da ETE-Franca, 60 dias após o plantio de milho, apresentaram em média $79 \%$ de similaridade com o controle.

As comunidades de Bacteria do solo argiloso tratado com biossólido da ETE-Barueri apresentaram aproximadamente $76 \%$ de similaridade em relação ao controle. Em solo arenoso tratado com biossólido da ETE-Franca, as comunidades de Bacteria apresentaram aproximadamente $73 \%$ de similaridade com o controle sem biossólido. Quando o biossólido da ETE-Barueri foi utilizado, as comunidades de Bacteria do solo arenoso apresentaram $68 \%$ de similaridade com o controle sem biossólidos (Tabela 11).

As comunidades de Bacteria do solo argiloso, quando tratado com o biossólido da ETE-Franca, foram mais similares ao controle, independente da época de amostragem 74,2 e $79 \%$, respectivamente. Quando este solo foi tratado com o biossólido da ETE-Barueri, a comunidade teve o valor de similaridade reduzido para 62,4 e $76 \%$ para 30 e 60 dias após o plantio do milho, em relação ao controle. Houve um acréscimo nos coeficientes de similaridade em relação à época de amostragem e um decréscimo em relação ao tipo de biossólido.

Resultados semelhantes foram observados em solo arenoso, porém, neste caso, o efeito foi mais acentuado, pois os valores de similaridade foram menores, o que sugere maior alteração na estrutura da comunidade de Bacteria, em relação aos controles. Quando o solo arenoso foi tratado com biossólido da ETE-Franca a similaridade foi de 65,5 e $76 \%$ e quando tratado com o biossólido da ETE-Barueri apresentou similaridade de 53 e $68 \%$, 30 e 60 dias, respectivamente. Isso se deve provavelmente às características de textura e baixa capacidade de imobilização de metais pesados, tornando estes prontamente disponíveis na solução do solo (Ross, 1994). Os coeficientes de similaridade obtidos para as amostras coletadas 60 dias após o plantio do 
Tabela 10. Coeficientes de similaridade binários ("simple matching") dos perfis de amplicons da região V3 do rDNA 165 de Bacteria, 30 dias após o plantio de milho.

\begin{tabular}{llllllll}
\hline & ARGD1 & ARGF2 & ARGF3 & ARGF4 & ARGB2 & ARGB3 & ARGB4 \\
\hline ARGD1 & 1,000 & & & & & & \\
ARGF2 & 0,710 & 1,000 & & & & & \\
ARGF3 & 0,774 & 0,742 & 1,000 & & & & \\
ARGF4 & 0,742 & 0,774 & 0,903 & 1,000 & & & \\
ARGB2 & 0,613 & 0,581 & 0,645 & 0,677 & 1,000 & & \\
ARGB3 & 0,613 & 0,516 & 0,645 & 0,677 & 0,871 & 1,000 & \\
ARGB4 & 0,645 & 0,613 & 0,484 & 0,581 & 0,774 & 0,710 & 1,000 \\
\hline & ARED1 & AREF2 & AREF3 & AREF4 & AREB2 & AREB3 & AREB4 \\
\hline ARED1 & 1,000 & & & & & & \\
AREF2 & 0,677 & 1,000 & & & & & \\
AREF3 & 0,645 & 0,710 & 1,000 & & & & \\
AREF4 & 0,645 & 0,710 & 0,742 & 1,000 & & & \\
AREB2 & 0,516 & 0,645 & 0,742 & 0,613 & 1,000 & & \\
AREB3 & 0,484 & 0,613 & 0,645 & 0,645 & 0,645 & 1,000 & \\
AREB4 & 0,581 & 0,581 & 0,548 & 0,613 & 0,613 & 0,710 & 1,000 \\
\hline
\end{tabular}

Tipo de solo: solo argiloso (ARG); solo arenoso (ARE).

Doses: Dose 1, sem adição de biossólido; ETE-Franca (F): Dose 2, $6 \mathrm{Mg} \mathrm{ha}^{-1}$; Dose 3, 24 $\mathrm{Mg} \mathrm{ha}^{-1}$; Dose 4, $96 \mathrm{Mg} \mathrm{ha}^{-1}$; ETE-Barueri (B): Dose 2, $31 \mathrm{Mg} \mathrm{ha}^{-1}$; Dose 3, $62 \mathrm{Mg} \mathrm{ha}^{-1}$; Dose 4, $124 \mathrm{Mg} \mathrm{ha}^{-1}$. 
Tabela 11. Coeficientes de similaridade binários ("simple matching") dos perfis amplicons da região V3 do rDNA 165 de Bacteria, 60 dias após o plantio de milho.

\begin{tabular}{llllllll}
\hline & ARGD1 & ARGF2 & ARGF3 & ARGF4 & ARGB2 & ARGB3 & ARGB4 \\
\hline ARGD1 & 1,000 & & & & & & \\
ARGF2 & 0,917 & 1,000 & & & & & \\
ARGF3 & 0,708 & 0,708 & 1,000 & & & & \\
ARGF4 & 0,750 & 0,750 & 0,708 & 1,000 & & & \\
ARGB2 & 0,750 & 0,833 & 0,625 & 0,833 & 1,000 & & \\
ARGB3 & 0,792 & 0,792 & 0,667 & 0,875 & 0,792 & 1,000 & \\
ARGB4 & 0,750 & 0,750 & 0,625 & 0,667 & 0,833 & 0,708 & 1,000 \\
\hline & ARED1 & AREF2 & AREF3 & AREF4 & AREB2 & AREB3 & AREB4 \\
\hline ARED1 & 1,000 & & & & & & \\
AREF2 & 0,800 & 1,000 & & & & & \\
AREF3 & 0,720 & 0,760 & 1,000 & & & & \\
AREF4 & 0,680 & 0,560 & 0,560 & 1,000 & & & \\
AREB2 & 0,600 & 0,640 & 0,720 & 0,680 & 1,000 & & \\
AREB3 & 0,760 & 0,560 & 0,560 & 0,680 & 0,680 & 1,000 & \\
AREB4 & 0,680 & 0,640 & 0,640 & 0,440 & 0,600 & 0,600 & 1,000 \\
\hline
\end{tabular}

Tipo de solo: solo argiloso (ARG); solo arenoso (ARE).

Doses: Dose 1, sem adição de biossólido; ETE-Franca (F): Dose 2, $6 \mathrm{Mg} \mathrm{ha}^{-1}$; Dose 3, 24 $\mathrm{Mg} \mathrm{ha}^{-1}$; Dose 4, $96 \mathrm{Mg} \mathrm{ha}^{-1}$; ETE-Barueri (B): Dose 2, $31 \mathrm{Mg} \mathrm{ha}^{-1}$; Dose 3, $62 \mathrm{Mg} \mathrm{ha}^{-1}$; Dose 4, $124 \mathrm{Mg} \mathrm{ha}^{-1}$. 
milho, foram superiores aos obtidos após 30 dias do plantio de milho. Isto pode ser explicado pela presença de cátions inorgânicos e matéria orgânica disponíveis.

Estes dois componentes podem reduzir a toxicidade de metais pesados em solos contaminados (Kunito et al., 1999). Khan \& Scullion (2000) encontraram correlação negativa entre a biomassa e a concentração de metais pesados em solos arenosos. Em solos argilosos, esta correlação não foi observada, sugerindo que a disponibilidade de metais pode ser afetada pela presença de sítios de ligação em maior abundância em função da textura do solo. Frostegård et al. (1993) verificaram as variações nos coeficientes de similaridade dos perfis de fosfolipídios de dois solos: floresta e arenoso, enriquecidos com diferentes concentrações de $\mathrm{Cd}, \mathrm{Cu}, \mathrm{Ni}, \mathrm{Pb}$ ou $\mathrm{Zn}$. Os resultados obtidos demonstram que a estrutura da comunidade pode ser modificada, de acordo com a dose e tipo de metal adicionado. Porém, em alguns casos, a resposta independe do tipo de metal. Da mesma forma, Bending et al. (2000) verificou que as raízes das plantas liberam grandes quantidades de compostos orgânicos que são a principal fonte de energia para os microrganismos que habitam a rizosfera, sendo estes relacionados ao estágio de desenvolvimento e idade da planta. Assim, alterações na diversidade genética e funcional podem ser observadas, com reflexos na estrutura da comunidade.

Por outro lado, Brim et al. (1999) determinaram que, bactérias com capacidades metabólicas raras ou resistentes à metais pesados, podem também estar presentes, induzindo a uma maior dominância destas espécies. Duineveld et al. (1998) usando PCR-DGGE encontraram similaridade entre a comunidade bacteriana da rizosfera de crisântemo e o solo sem cultivo. Os autores sugerem que o potencial de impacto das raízes nas populações bacterianas no solo não foi grande o suficiente para induzir mudanças na 
estrutura da comunidade, pois foram estáveis em relação ao tempo e espaço. Porém, correlação positiva foi observada entre as mudanças na estrutura da comunidade de Bacteria com a idade e o estágio de desenvolvimento da planta.

A análise de agrupamento hierárquico do solo argiloso, 30 dias após o plantio do milho, possibilitou a identificação de 2 grupos de comunidades de Bacteria (Figura 14A). O primeiro grupo ocorre nos solos tratados com as doses 2, 3 e 4 do biossólido da ETE-Franca e o controle sem biossólido; o segundo grupo ocorre nos solos com as doses 2, 3 e 4 do biossólido da ETE-Barueri. Em solo arenoso, na mesma época de coleta, foi possível a identificação de 3 grupos. O primeiro ocorre no controle sem biossólido; o segundo ocorre no solo com as doses 2, 3 e 4 do biossólido da ETE-Franca e a dose 2 do biossólido da ETE-Barueri; o terceiro grupo ocorre no solo tratado com as doses 3 e 4 do biossólido da ETE-Barueri. Na segunda época de amostragem, 60 dias após o plantio do milho, em solo argiloso foram identificados 4 grupos (Figura 14C). 0 primeiro grupo ocorre no solo tratado com a dose 3 do biossólido da ETEFranca; o segundo grupo ocorre nos solos tratados com a dose 4 do biossólido da ETE- Franca e a dose 3 do biossólido da ETE-Barueri; o terceiro grupo ocorre com o controle sem biossólido e a dose 2 do biossólido da ETE-Franca; o quarto grupo ocorre com o solo tratado com as doses 2 e 4 do biossólido da ETE-Barueri. Em solo arenoso, 60 dias após o plantio do milho, foram identificados 3 grupos de estrutura de comunidade de Bacteria (Figura 14D). 0 primeiro grupo ocorre no solo tratado com as doses 2 e 3 do biossólido da ETEBarueri e a dose 4 do biossólido da ETE-Franca; o segundo grupo ocorre em solo tratado com as doses 2 e 3 do biossólido da ETE-Franca e o controle sem biossólido; o terceiro grupo ocorre em solo tratado com a dose 4 do biossólido da ETE-Barueri. 
A

B

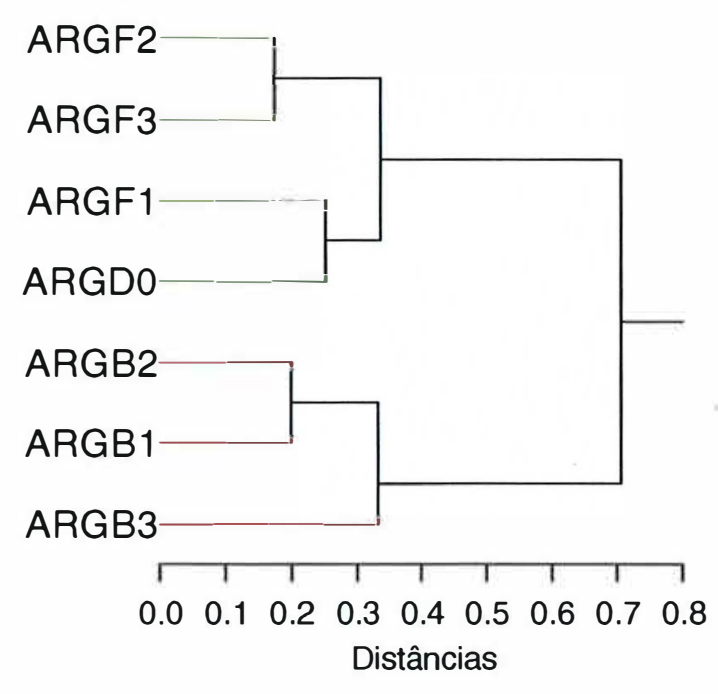

C

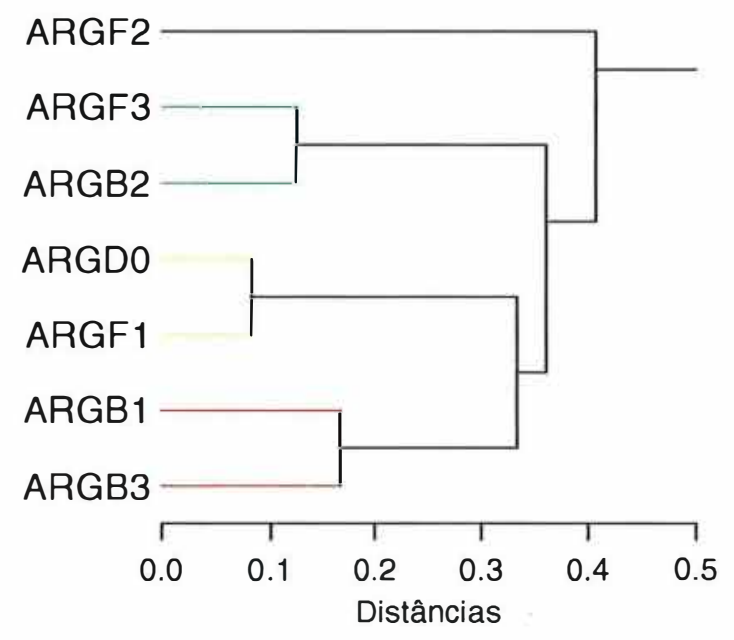

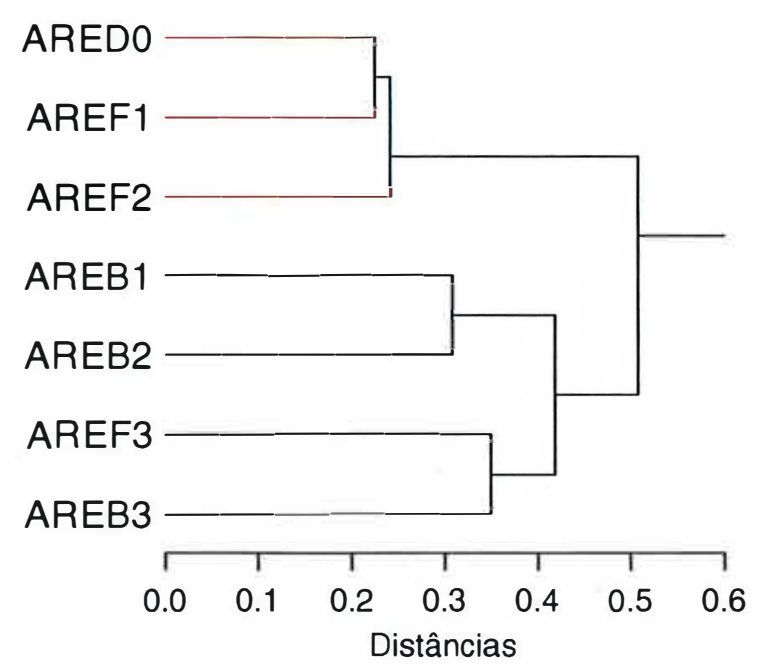

D

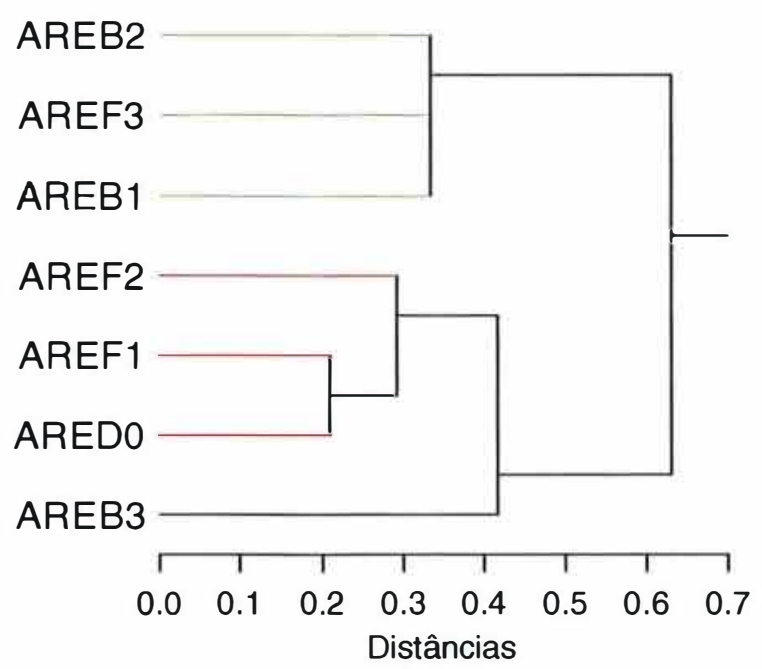

Figura 14 - Dendogramas mostrando as relações entre os amplicons sintetizados por PCR com os iniciadores BA338fCG e UN518r de solos argiloso (ARG) ou arenoso (ARE) tratados com biossólidos. Dose 1, sem adição de biossólido (ARGD0; ARED0); ETE-Franca: Dose 2, $6 \mathrm{Mg} \mathrm{ha}^{-1}$; Dose 3, $24 \mathrm{Mg} \mathrm{ha}^{-1}$; Dose 4, $96 \mathrm{Mg} \mathrm{ha}^{-1}$; ETE-Barueri: Dose 2, $31 \mathrm{Mg} \mathrm{ha}^{-1}$; Dose 3, $62 \mathrm{Mg} \mathrm{ha}^{-1}$; Dose 4, $124 \mathrm{Mg} \mathrm{ha}^{-1}$. A e B, 30 dias após o plantio de milho; C e D, 60 dias após o plantio de milho. 
Esses mostram maior similaridade entre solos tratados com 0 biossólido da ETE-Franca em relação ao controle, em ambos os tipos de solo e época de amostragem, conforme já observado pelos coeficientes de similaridade. Isso sugere que o solo tratado com biossólido da ETE-Franca a recuperação ocorre mais rápida, ou seja, a resiliência do sistema foi maior.

Kowalchuk et al. (1997), observaram as diferenças fisiológicas de várias espécies da subdivisão $\beta$ de bactérias oxidantes de amônia, as quais reduziam as taxas de nitrificação em resposta a fatores ambientais. A determinação da correlação entre a composição da comunidade e as relações espaciais dos diferentes membros com uma função na comunidade, podem ser importantes para melhor compreensão dos ciclos biogeoquímicos nos quais as transformações são catalisadas pelo consórcio de muitas espécies e não por um único microrganismo.

Contudo, outros fatores podem estar relacionados, como verificado por Frostegård et al. (1993) que analisaram solos de diferentes texturas, observando que em cada tratamento com diferentes doses e tipos de metais, um grupo de ácido graxo pode ser induzido ou reduzido. Eles concluem que a estrutura da comunidade pode ser modificada, resultando na seleção de espécies tolerantes a metais. Filser et al. (1995) analisaram um total de 15 solos de um agrossistema cultivado com trigo e cevada, em rotação de cultura, foi analisado em relação à composição da microbiota do solo. Os autores concluíram que o manejo utilizado se reflete em alterações na composição da microbiota e estas mudanças de estrutura têm pronunciado efeito na ciclagem de nutrientes.

Uma nova avaliação da estrutura da comunidade foi feita com base na análise dos amplicons da região V1-V3 do rDNA 16S, separados por DGGE (Figura 15). A representação esquemática do gel apresentado na Figura 15 
pode ser vista na Figura 16. Para amostras coletadas após 30 dias do plantio de milho, cerca de 19 amplicons foram identificados no gel de DGGE, apresentando poucas diferenças nos valores de Rf. Cerca de $21 \%$ dos amplicons estão presentes em todos os tratamentos, cujos Rfs são: 0,185 , $0,193,0,209$ e 0,225 . Os amplicons de Rfs 0,$183 ; 0,201 ; 0,210$ e 0,387 , apresentaram valores de Rf muito próximo aos citados anteriormente, porém, eles estão presentes como um único amplicon em diferentes tratamentos, independente de dose ou tipo de solo. Em relação ao tratamento a que estes amplicons pertencem, em geral, são encontrados nas duas posições de Rf.

As amostras de solo arenoso apresentaram um acréscimo no número de amplicons de aproximadamente $32 \%$ em relação às amostras de solo argiloso, independente do biossólido utilizado. Quando o solo foi tratado com o biossólido da ETE-Barueri o número de amplicons foi $16 \%$ maior. Após 60 dias do plantio do milho, cerca de 23 amplicons foram detectados, conforme a Figura 17, cuja representação esquemática pode ser vista na Figura 18. Nos Rfs 0,360 e 0,508 foram detectados os amplicons presentes em amostras de solo argiloso tratado com biossólido da ETE-Franca e o controle sem aplicação de biossólido. Cerca de $13 \%$ dos amplicons estão presentes em todas as amostras cujos Rfs são: 0,286; 0,339 e 0,691. Nas amostras de solos controles, coletadas após 60 dias do plantio do milho, foram detectados os amplicons de Rfs 0,$097 ; 0,390$ e 0,487, presentes somente nesta amostra. Da mesma forma os amplicons de Rf 0,398 e 0,508 foram detectados somente em solo argiloso tratado com quantidade equivalente a $6 \mathrm{Mg} \mathrm{ha}^{-1}$ do biossólido da ETE-Franca. O amplicon de Rf 0,625 só foi detectado numa amostra de solo argiloso tratada com quantidade equivalente a $24 \mathrm{Mg} \mathrm{ha}^{-1}$ biossólido da ETE-Barueri. Os amplicons com Rfs 0,304 e 0,314, ao contrário, só não foram detectados nas amostras de solos controle (D1) e em solo argiloso tratado com quantidade equivalente a $6 \mathrm{Mg} \mathrm{ha}^{-1}$, respectivamente. 
Solo

Biossólido

Dose
ARGILOSO

$\frac{\text { ETE-FRANCA }}{234} \frac{\text { ETE-BARUERI }}{2344}$

ARENOSO

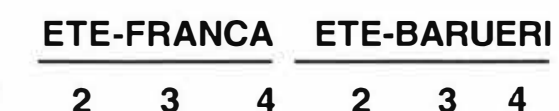

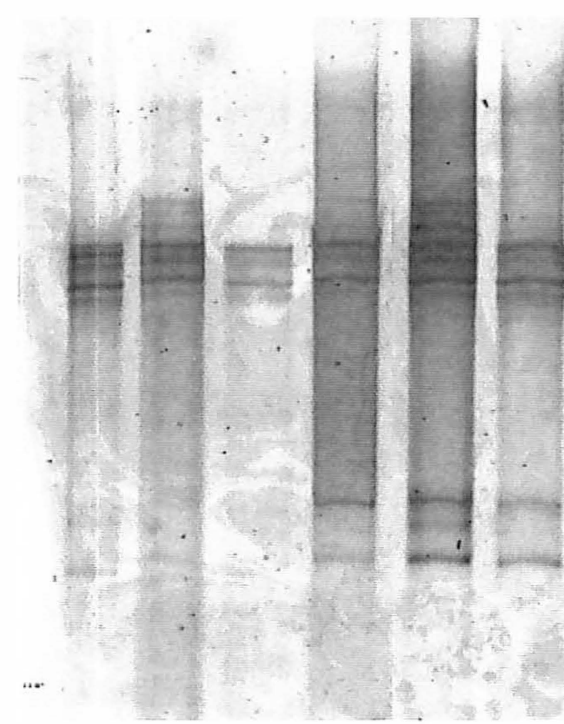
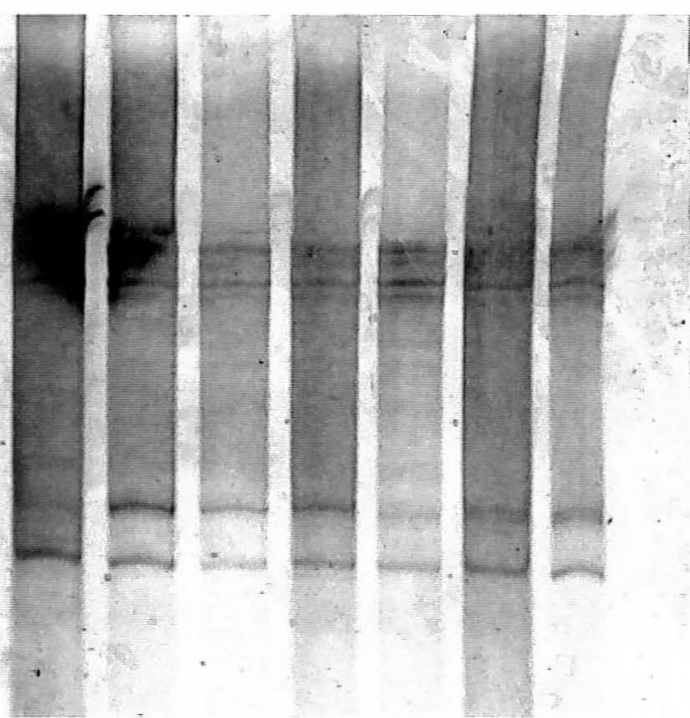

Figura 15 - Amplicons da região V1-V3 do rDNA $16 \mathrm{~S}$ das comunidades de Bacteria de solo argiloso e arenoso tratados com biossólidos da ETE-Franca ou ETE-Barueri. Os amplicons foram separados em gel de poliacrilamida $6 \%$, com gradiente desnaturante (10-45\%). O DNA foi visualizado por coloração com SYBR Green I. Dose 1, sem aplicação de biossólido; ETE-Franca: Dose 2, $6 \mathrm{Mg} \mathrm{ha}^{-1}$; Dose 3, $24 \mathrm{Mg} \mathrm{ha}^{-1}$; Dose 4, $96 \mathrm{Mg} \mathrm{ha}^{-1}$; ETE-Barueri: Dose 2, 31 $\mathrm{Mg} \mathrm{ha}^{-1}$; Dose 3, $62 \mathrm{Mg} \mathrm{ha}^{-1}$; Dose 4, $124 \mathrm{Mg} \mathrm{ha}^{-1}$. Amostras coletadas após 30 dias do plantio de milho. 


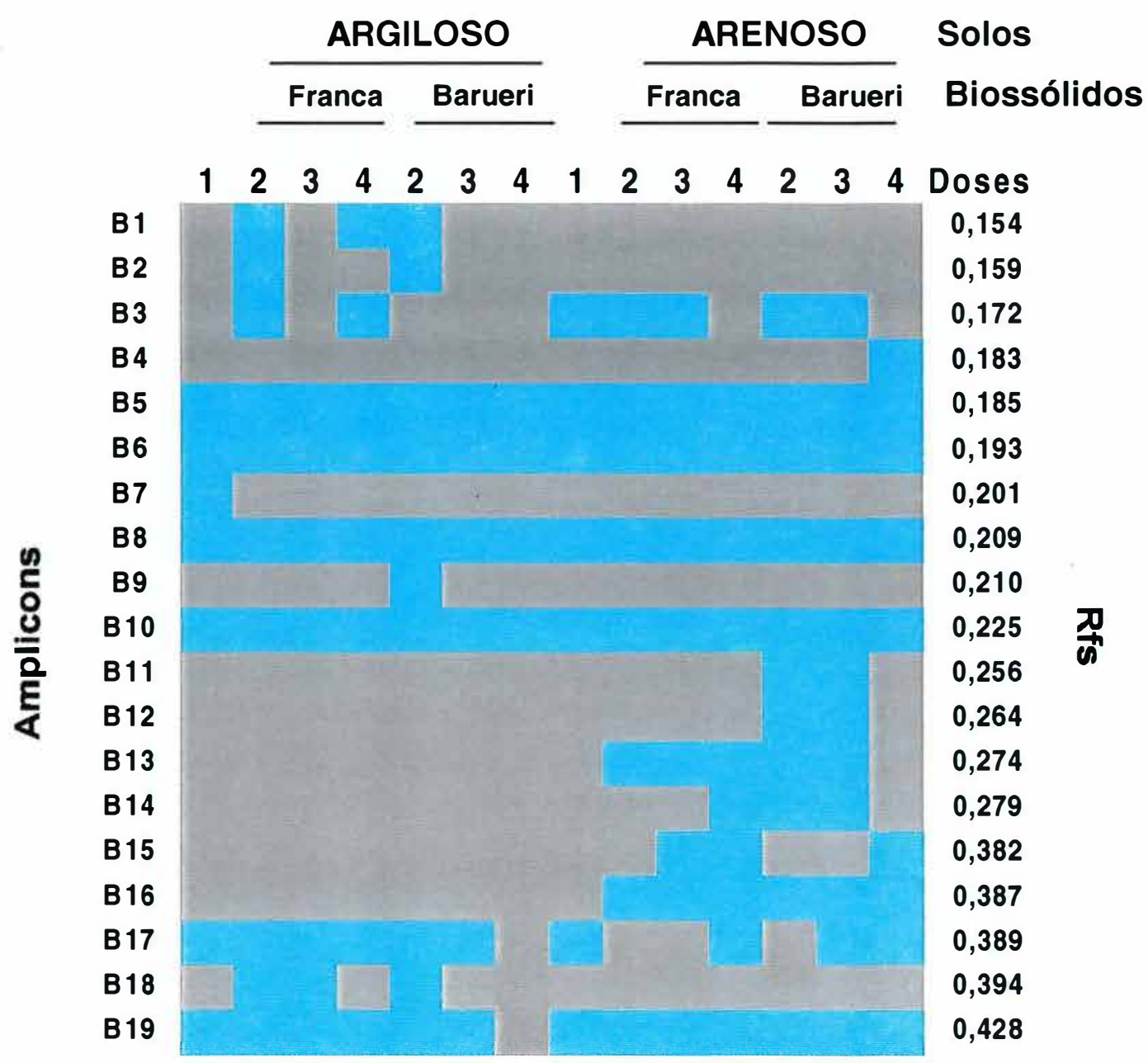

Figura 16 - Diagrama representando os amplicons da região V1-V3 do rDNA 165 das comunidades de Bacteria de solo argiloso e arenoso, tratados com biossólidos da ETEFranca ou Barueri. Dose 1, sem adição de biossólido; ETE-Franca: Dose 2, $6 \mathrm{Mg} \mathrm{ha}^{-1}$; Dose 3, $24 \mathrm{Mg} \mathrm{ha}^{-1}$; Dose 4, $96 \mathrm{Mg} \mathrm{ha}^{-1}$; ETE-Barueri: Dose 2, $31 \mathrm{Mg} \mathrm{ha}^{-1}$; Dose 3, $62 \mathrm{Mg} \mathrm{ha}^{-1}$; Dose 4, $124 \mathrm{Mg} \mathrm{ha}^{-1}$. Amostras coletadas após 30 dias do plantio do milho. 
Solo

Biossólido

Dose
ARGILOSO

$\begin{array}{lllll}\text { ETE-FRANCA } & \frac{\text { ETE-BARUERI }}{2} & \frac{2}{2} & 3 & 4\end{array}$

\section{ARENOSO}

\begin{tabular}{|c|c|}
\hline ETE-FRANCA & ETE-BARUERI \\
\hline 2 & 3 \\
\hline
\end{tabular}
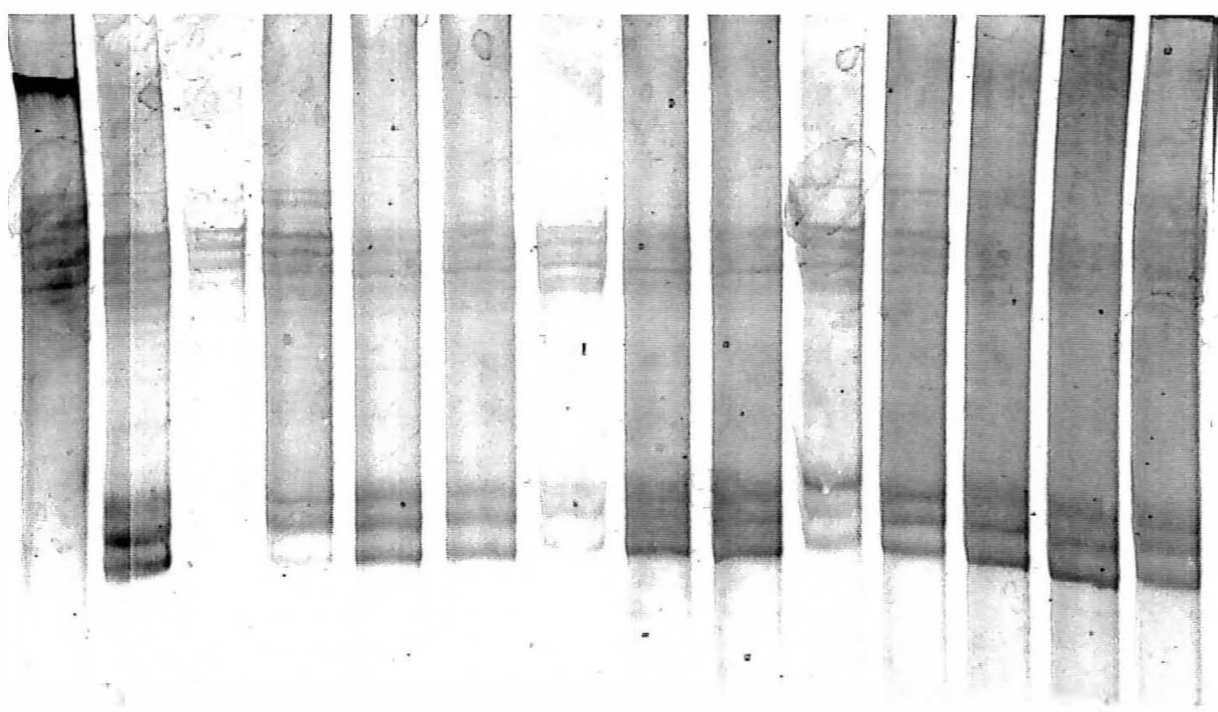

Figura 17 - Amplicons da região V1-V3 do rDNA $16 \mathrm{~S}$ das comunidades de Bacteria de solo argiloso e arenoso com biossólidos da ETEFranca ou ETE-Barueri. Os amplicons foram separados em gel de poliacrilamida $6 \%$, com gradiente desnaturante (10-45\%). $O$ DNA foi visualizado por coloração com SYBR Green I. Dose 1, sem adição de biossólido; ETE-Franca: Dose 2, $6 \mathrm{Mg} \mathrm{ha}^{-1}$; Dose 3, $24 \mathrm{Mg} \mathrm{ha}^{-1}$; Dose 4, $96 \mathrm{Mg} \mathrm{ha}^{-1}$; ETE-Barueri: Dose 2, $31 \mathrm{Mg}$ ha $^{-1}$; Dose 3, $62 \mathrm{Mg} \mathrm{ha}^{-1}$; Dose 4, $124 \mathrm{Mg} \mathrm{ha}^{-1}$. Amostras coletadas após 60 dias do plantio de milho. 


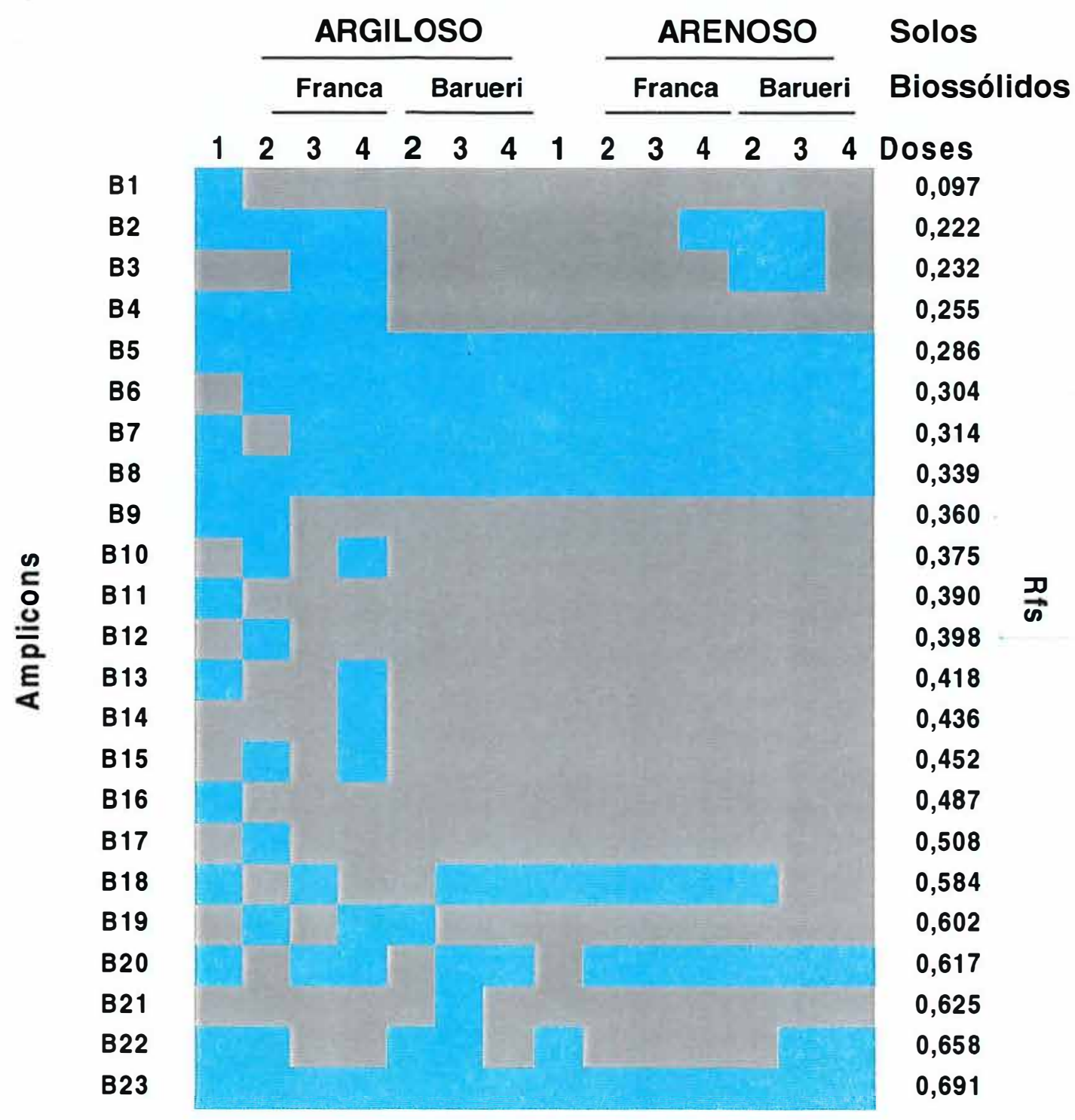

Figura 18 - Diagrama representando os amplicons da região V1-V3 do rDNA $16 \mathrm{~S}$ das comunidades de Bacteria de solo argiloso e arenoso, tratados com biossólidos da ETE-Franca ou Barueri. Dose 1, sem adição de biossólido; ETE-Franca: Dose 2, $6 \mathrm{Mg} \mathrm{ha}^{-1}$; Dose 3, $24 \mathrm{Mg} \mathrm{ha}^{-1}$; Dose 4, $96 \mathrm{Mg} \mathrm{ha}^{-1}$; ETE-Barueri: Dose 2, $31 \mathrm{Mg}$ ha $^{-1}$; Dose 3, $62 \mathrm{Mg} \mathrm{ha}^{-1}$; Dose 4, $124 \mathrm{Mg} \mathrm{ha}^{-1}$. Amostras coletadas após 60 dias do plantio do milho. 
O número de amplicons comum a todos os tratamentos, variou de 4 para 3, de 30 para 60 dias após o plantio do milho. Entre as duas amostragens também foram encontradas diferenças entre a maior abundância de amplicons, como a maior concentração em solo arenoso, 30 dias após o plantio de milho e maior concentração de amplicons em solo argiloso 60 dias após o plantio de milho. Os amplicons obtidos pela amplificação com o conjunto de iniciadores $63 f G C$ e $518 \mathrm{r}$ e separados por DGGE, foram pouco diferenciados devido a sua baixa sensibilidade em detectar as variações na estrutura da comunidade. Contudo, as alterações ocorridas podem ser da mesma forma justificada pela presença de matéria orgânica, plantas de milho e metais pesado em diferentes proporções e estágios de desenvolvimento.

Kozdroj \& van Elsas (2000) analisaram a resposta da comunidade microbiana sob influência de exsudatos de raízes em solo poluído com metais pesados. Os resultados mostraram que os exsudatos têm um efeito significativo no desenvolvimento de populações de bactérias em solos contaminados com metais pesados. Conforme o impacto destes metais, diferentes populações são inibidas ou induzidas, produzindo mudanças na estrutura da comunidade. Contudo, Kostov et al. (2001) afirmam que biossólido é um poderoso agente de recuperação da fertilidade do solo, mesmo que este tenha sido contaminado com metal pesado como o cobre. Por outro lado, Dalmastri et al. (1999) analisaram a influencia do tipo de solo, cultivar de milho e diversidade genética na presença das populações de Burkholderia cepacia. Segundo os autores não há variação entre a estrutura genética das populações de Burkholderia cepacia, as quais estão distribuídas aleatóriamente entre a rizosfera e fora dela.

A comparação entre os coeficientes de similaridade binários foi feita para verificar as alterações da estrutura da comunidade de géis de da região V1-V3 do rDNA 16S, separados por DGGE. Os coeficientes de similaridade gerados foram utilizados para comparar as estruturas das comunidades de 
Bacteria do solo argiloso e arenoso, tratadas com diferentes doses de biossólidos e avaliadas 30 e 60 dias após o plantio de milho, com os controles sem biossólidos, e podem ser vistas nas Tabelas 12 e 13. Em solo argiloso, após 30 dias do plantio de milho, as comunidades de Bacteria dos solos que receberam biossólido da ETE-Franca apresentaram aproximadamente $70 \%$ de similaridade com os controles sem adição de biossólido. Quando o biossólido da ETE-Barueri foi adicionado, as comunidades de Bacteria do solo apresentaram $76 \%$ de similaridade em relação ao controle. Para mesma época de coleta, em solo arenoso, a comunidade de Bacteria que recebeu o biossólido da ETE-Franca foi $100 \%$ similar ao controle, independente da dose de biossólido aplicada. Nos solo tratado com o biossólido da ETE- Barueri, as comunidades de Bacteria apresentaram $94 \%$ de similaridade em relação aos controles sem biossólidos. Após 60 dias do plantio do milho, as comunidades de Bacteria de solo argiloso com biossólido da ETE-Franca, apresentaram aproximadamente $52 \%$ de similaridade com o controle. Pouca diferença foi observada em relação à comunidade de Bacteria de solo tratado com o biossólodo da ETE-Barueri, na qual a similaridade foi de 58\%. Na mesma época de coleta em solo arenoso, os solos tratados com biossólido da ETE-Franca, apresentaram $90 \%$ de similaridade com o controle. Com o biossólodo da ETEBarueri, a similaridade foi de $86 \%$, em relação ao controle.

Os coeficientes de similaridade das amostras de solos arenosos tratados com biossólido da ETE-Barueri foram mais similares aos controles sem adição de biossólidos. Em geral, foram observadas pequenas diferenças nos valores dos coeficientes de similaridade entre as amostras de solos tratadas com diferentes biossólidos. Em relação ao tipo de solo, os tratamentos referentes às amostras coletadas após 60 dias do plantio de milho, apresentaram os menores valores de similaridade, 52\% ETE-Franca e 58\% ETE-Barueri. 
Tabela 12. Coeficientes de similaridade binários ("simple matching") dos perfis de amplicons da região V1-V3 do rDNA $16 \mathrm{~S}$ de Bacteria, 30 dias após o plantio de milho

\begin{tabular}{|c|c|c|c|c|c|c|c|}
\hline & ARGD1 & ARGF2 & ARGF3 & ARGF4 & ARGB2 & ARGB3 & ARGB4 \\
\hline ARGD1 & 1,000 & & & & & & \\
\hline ARGF2 & 0,545 & 1,000 & & & & & \\
\hline ARGF3 & 0,818 & 0,727 & 1,000 & & & & \\
\hline ARGF4 & 0,727 & 0,818 & 0,727 & 1,000 & & & \\
\hline ARGB2 & 0,545 & 0,455 & 0,364 & 0,636 & 1,000 & & \\
\hline ARGB3 & 0,909 & 0,636 & 0,909 & 0,818 & 0,455 & 1,000 & \\
\hline \multirow[t]{2}{*}{ ARGB4 } & 0,818 & 0,727 & 1,000 & 0,727 & 0,364 & 0,909 & 1,000 \\
\hline & ARED1 & AREF2 & AREF3 & AREF4 & AREB2 & AREB3 & AREB4 \\
\hline ARED1 & 1,000 & & & & & & \\
\hline AREF2 & 1,000 & 1,000 & & & & & \\
\hline AREF3 & 1,000 & 1,000 & 1,000 & & & & \\
\hline AREF4 & 1,000 & 1,000 & 1,000 & 1,000 & & & \\
\hline AREB2 & 1,000 & 1,000 & 1,000 & 1,000 & 1,000 & & \\
\hline AREB3 & 0,909 & 0,909 & 0,909 & 0,909 & 0,909 & 1,000 & \\
\hline AREB4 & 0,909 & 0,909 & 0,909 & 0,909 & 0,909 & 0,909 & 1,000 \\
\hline
\end{tabular}

Tipo de solo: solo argiloso (ARG); solo arenoso (ARE).

Doses: Dose 1, sem adição de biossólido; ETE-Franca (F): Dose 2, $6 \mathrm{Mg} \mathrm{ha}^{-1}$; Dose 3, $24 \mathrm{Mg}$ ha $^{-1}$; Dose 4, $96 \mathrm{Mg} \mathrm{ha}^{-1}$; ETE-Barueri (B): Dose 2, $31 \mathrm{Mg} \mathrm{ha}^{-1}$; Dose 3, $62 \mathrm{Mg} \mathrm{ha}^{-1}$; Dose 4, $124 \mathrm{Mg} \mathrm{ha}^{-1}$. 
Tabela 13. Coeficientes de similaridade binários ("simple matching") dos perfis de amplicons da região V1-V3 do rDNA 16S de Bacteria, 60 dias após o plantio de milho

\begin{tabular}{llllllll}
\hline & ARGD1 & ARGF2 & ARGF3 & ARGF4 & ARGB2 & ARGB3 & ARGB4 \\
\hline ARGD1 & 1,000 & & & & & & \\
ARGF2 & 0,435 & 1,000 & & & & & \\
ARGF3 & 0,652 & 0,522 & 1,000 & & & & \\
ARGF4 & 0,478 & 0,609 & 0,739 & 1,000 & & & \\
ARGB2 & 0,522 & 0,652 & 0,696 & 0,609 & 1,000 & & \\
ARGB3 & 0,609 & 0,478 & 0,783 & 0,522 & 0,826 & 1,000 & \\
ARGB4 & 0,609 & 0,478 & 0,870 & 0,609 & 0,826 & 0,913 & 1,000 \\
\hline & ARED1 & AREF2 & AREF3 & AREF4 & AREB2 & AREB3 & AREB4 \\
\hline ARED1 & 1,000 & & & & & & \\
AREF2 & 0,913 & 1,000 & & & & & \\
AREF3 & 0,913 & 1,000 & 1,000 & & & & \\
AREF4 & 0,870 & 0,957 & 0,957 & 1,000 & & & \\
AREB2 & 0,826 & 0,913 & 0,913 & 0,957 & 1,000 & & \\
AREB3 & 0,826 & 0,826 & 0,826 & 0,870 & 0,913 & 1,000 & \\
AREB4 & 0,913 & 0,913 & 0,913 & 0,870 & 0,826 & 0,913 & 1,000 \\
\hline
\end{tabular}

Tipo de solo: solo argiloso (ARG); solo arenoso (ARE).

Doses: Dose 1, sem adição de biossólido; ETE-Franca (F): Dose 2, $6 \mathrm{Mg} \mathrm{ha}^{-1}$; Dose 3, $24 \mathrm{Mg}$ ha-1; Dose 4, $96 \mathrm{Mg} \mathrm{ha}^{-1}$; ETE-Barueri (B): Dose 2, $31 \mathrm{Mg} \mathrm{ha}^{-1}$; Dose 3, $62 \mathrm{Mg} \mathrm{ha}^{-1}$; Dose 4, $124 \mathrm{Mg} \mathrm{ha}^{-1}$. 
Estes foram os menores valores de similaridade observados para as amostras amplificadas com o conjunto de iniciadores $63 \mathrm{fGC}$ e $518 \mathrm{r}$. Isso sugere que os fragmentos gerados com este conjunto de iniciadores (63fGC e 518r), foram menos sensíveis para demonstrar as mudanças na estrutura das comunidades destes solos.

Resultados semelhantes foram obtidos com a análise de agrupamento hierárquico, 4 grupos representam a comunidades de Bacteria, conforme a Figura 19. O primeiro grupo é formado pelo controle sem biossólido, e o solo tratado com quantidade equivalente a $6 \mathrm{Mg} \mathrm{ha}^{-1}$ do biossólido da ETEBarueri, o segundo grupo é formado por amostras de solo tratado com quantidade equivalente a $96 \mathrm{Mg} \mathrm{ha}^{-1}$ do biossólido da ETE-Barueri e o solo tratado com quantidade equivalente a $62 \mathrm{Mg} \mathrm{ha}^{-1}$ do biossólido da ETE-Franca. O terceiro grupo é formado por pelas amostras de solo tratadas com quantidades equivalentes a 31 e $124 \mathrm{Mg} \mathrm{ha}^{-1}$ do biossólido da ETE-Franca; o quarto grupo é formado pela amostra de solo tratado com quantidade equivalente a $6 \mathrm{Mg} \mathrm{ha}^{-1}$ do biossólido da ETE-Barueri (Figura 19A). Após 30 dias do plantio do milho em solo arenoso, o primeiro grupo é formado pelas amostras de solos tratadas com quantidades equivalentes a 6 e $24 \mathrm{Mg} \mathrm{ha}^{-1}$ do biossólido da ETE-Barueri; o segundo grupo é formado pelo controle sem biossólidos; o terceiro grupo é formado pelas amostras de solos tratados com quantidades equivalentes a 31 e $64 \mathrm{Mg} \mathrm{ha}^{-1}$ do biossólido da ETE-Franca; o quarto grupo é formado pelas amostras solos tratados com quantidades equivalentes a 96 e124 $\mathrm{Mg} \mathrm{ha}^{-1}$ dos biossólidos da ETE-Franca e ETE-Barueri, respectivamente (Figura 19B). Para o solo argiloso, após 60 dias do plantio do milho, foram identificados cinco grupos (Figura 19C). Os primeiro grupo é formado pelo controle sem biossólido; o segundo grupo é formado pelo solo tratado com a quantidade equivalente a $62 \mathrm{Mg} \mathrm{ha}^{-1}$ do biossólido da ETEFranca; o terceiro grupo é formado pelas amostras de solos tratadas com 


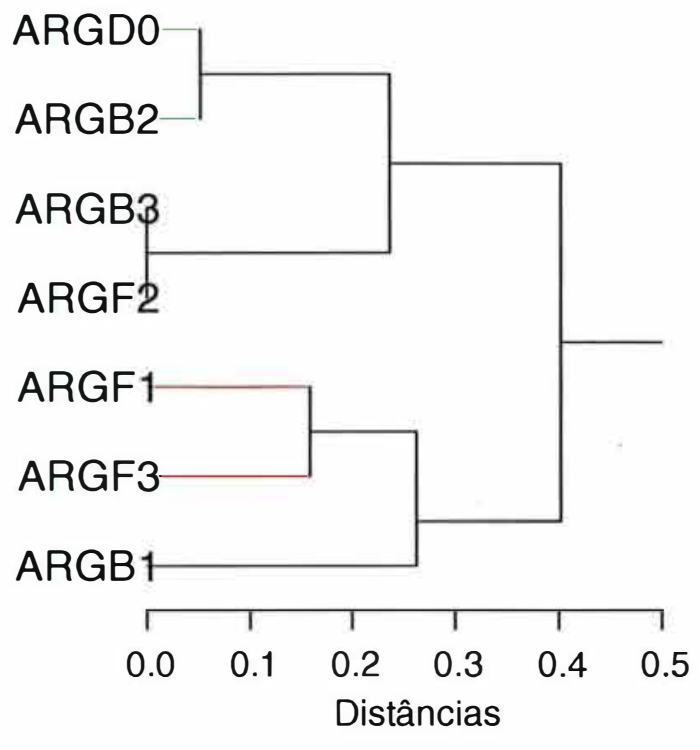

C

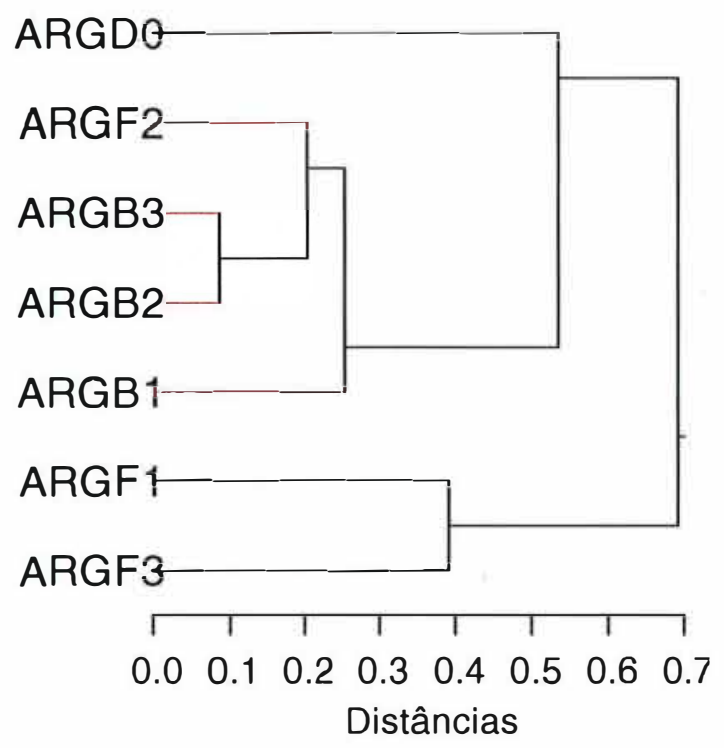

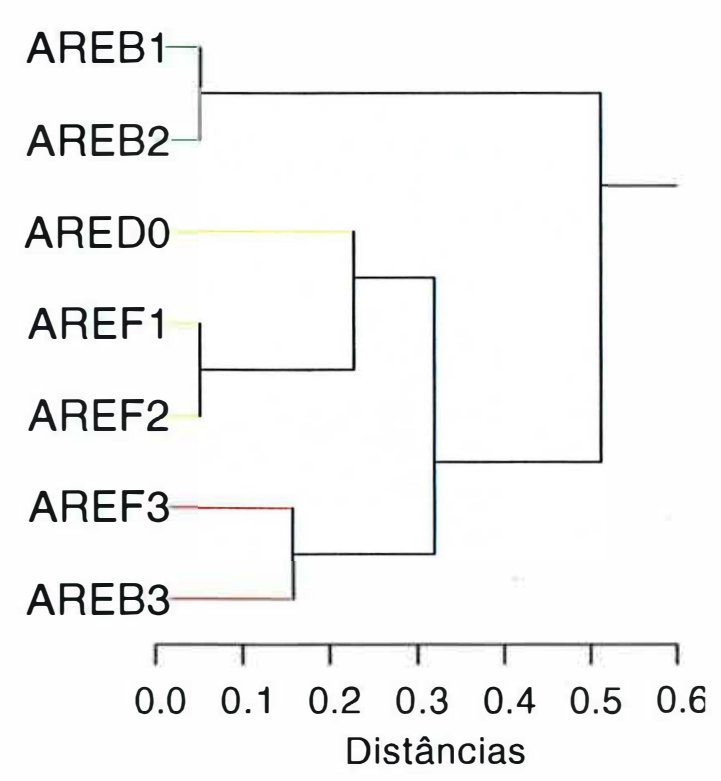

$\mathrm{D}$

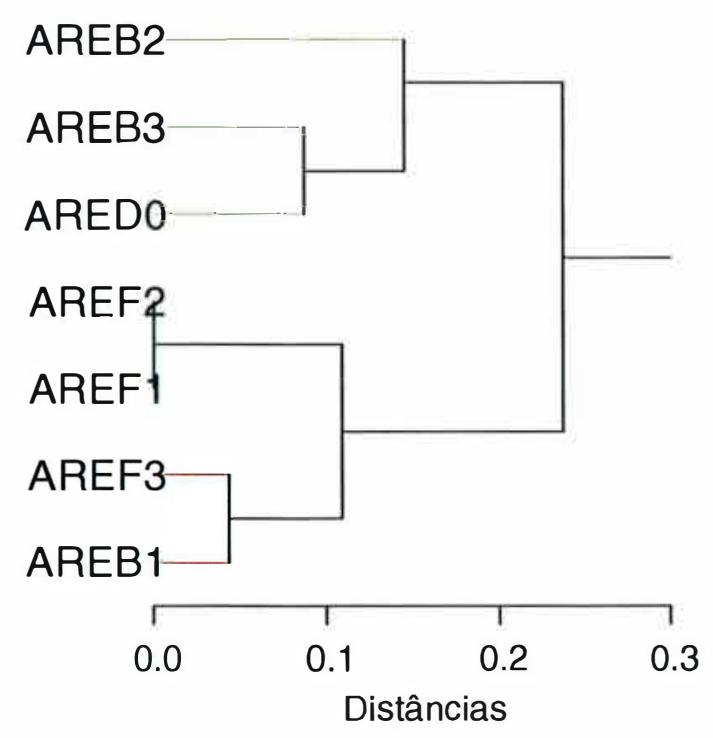

Figura 19 - Dendograma mostrando as relações entre os amplicons sintetizados por PCR com os iniciadores BA63fCG e UN518r de solos argiloso (ARG) ou arenoso (ARE), tratados com biossólidos. Dose 1, sem adição de biossólido (ARGD0; ARED0); ETE-Franca: Dose 2, $6 \mathrm{Mg} \mathrm{ha}^{-1}$; Dose 3, $24 \mathrm{Mg} \mathrm{ha}^{-1}$; Dose 4, $96 \mathrm{Mg} \mathrm{ha}^{-1}$; ETE-Barueri: Dose 2, $31 \mathrm{Mg} \mathrm{ha}^{-1}$; Dose 3, $62 \mathrm{Mg} \mathrm{ha}^{-1}$; Dose 3, $124 \mathrm{Mg} \mathrm{ha}^{-1}$. A e B, 30 dias após o plantio de milho; $C$ e D, 60 dias após o plantio de milho. 
quantidades equivalentes a 62 e $124 \mathrm{Mg} \mathrm{ha}^{-1}$ do biossólido da ETE-Barueri; o quarto grupo é formado pela amostra de solo tratado com quantidade equivalente a $6 \mathrm{Mg} \mathrm{ha}^{-1}$ do biossólido da ETE-Barueri; o quinto grupo é formado pelas amostras de solos tratados com quantidades equivalentes a 6 e $96 \mathrm{Mg} \mathrm{ha}^{-}$ 1 do biossólido da ETE-Franca. Após 60 dias do plantio do milho em solo arenoso foram identificados 4 grupos. O primeiro grupo é formado pela amostra de solo tratado com quantidade equivalente a $62 \mathrm{Mg} \mathrm{ha}^{-1} 3$ do biossólido da ETE-Barueri; o segundo grupo é formado pela amostra de solo tratado com quantidade equivalente a $124 \mathrm{Mg} \mathrm{ha}^{-1}$ do biossólido da ETE-Barueri e o controle sem biossólido; o terceiro grupo é formado pelas amostras de solos tratados com quantidades equivalentes a 6 e $24 \mathrm{Mg} \mathrm{ha}^{-1}$ do biossólido da ETE-Franca; e o quarto grupo é formado pelas amostras de solos tratados com quantidades equivalentes a $96 \mathrm{Mg} \mathrm{ha}^{-1}$ do biossólido da ETE-Franca e $6 \mathrm{Mg} \mathrm{ha}^{-1}$ do biossólido da ETE-Barueri. Estes resultados demonstram as poucas diferenças entre as amostras de solo tratadas com altas e baixas doses de biossólidos, quando avaliados com amplicons sintetizados por PCR com o conjunto de iniciadores 63fGC e 518r.

Fantroussi et al. (1999) - avaliaram solos tratados com herbicidas, usando dois conjuntos de iniciadores para determinar a estrutura da comunidade microbiana. Os resultados dos géis de PCR-DGGE das amostras amplificadas com o conjunto de iniciadores $338 \mathrm{fGC}$ e $518 \mathrm{r}$, mostraram que o herbicida afeta a comunidade microbiana, com algumas espécies eliminadas ou estimuladas, após sua aplicação. Contudo, os resultados obtidos com o conjunto de iniciadore 63fGC e 518r; não foram observadas diferenças entre os tratamentos.

O uso do PCR-DGGE com iniciadores universais revela as espécies mais dominantes. Nestes estudos as moléculas são comparadas por regiões altamente conservadas e também por regiões com variações nas seqüências. 
Por causa das taxas diferenciais de evolução das seqüências, relações filogenéticas em diversos níveis de hierarquia podem ser medidas por análises comparativas destas (Muyzer et al., 1993; Gelsomino et al., 1999). O conjunto de iniciadores 338fGC e 518r usados, foi originalmente desenhado por Øvreås et al. (1997), e amplifica um fragmento de 210 pb. Este fragmento pertence à região hipervariável V3 do rDNA 165 e tem proporcionado excelentes resultados na análise da diversidade de Bacteri, como tem sido descrito nos estudos de ecologia. Contudo, os perfis de DGGE de Bacteria de solos com diferentes tratamentos, produzem padrões de separação variados quando iniciadores de regiões diferentes do rDNA 165 são usados para amplificação por PCR. Estas diferenças nos padrões são esperadas, porque percentagem do conteúdo de GC e a conservação das seqüências de nucleotideos não são constantes para um determinado comprimento do gene (Nübel et al., 1999). Além disso, considerando que a heterogeneidade de seqüência pode ocorrer em células da mesma espécie, cada produto amplificado no gel, não pode corresponder a um organismo diferente, e um único organismo pode ser representado por diversos produtos de amplificação. Isso demonstra que o uso de PCR-DGGE como um método efetivo para monitorar as alterações qualitativas na estrutura de comunidades de Bacteria. Porém, as técnicas de isolamento de amplicons, reamplificação e clonagem destes DNAs podem complementar estes estudos.

\subsubsection{Análise dos índices de diversidade}

Embora não exista um consenso em torno de qual índice de diversidade é mais sensível para indicar os danos causados pelas condições de estresse sobre a microbiota do solo, vários índices foram calculados com base na abundância relativa dos amplicons do rDNA $16 \mathrm{~S}$ de Bacteria. Quando os iniciadores BA338fGC e UN518r foram usados para amplificação do DNA das amostras os seguintes índices de diversidade foram calculados: riqueza de 
amplicons (R; Figura 20), índice de Shannon Weaver (H; Figura 21), índice de dominância de Simpson (S; Figura 22) e índice de eqüitabilidade de amplicons (E; Figura 23).

Para o solo argiloso tratado com biossólido da ETE-Franca, 30 dias após o plantio de milho, quando considerada a dose de biossólido aplicada em relação ao controle sem biossólido, os resultados obtidos foram: a riqueza de amplicons, que está relacionada à riqueza de espécies (S), teve seu valor reduzido de 15 para 7 , com adição de quantidade equivalente a $6 \mathrm{Mg} \mathrm{ha}^{-1}$ de biossólido, aumentando para 14 após a aplicação de quantidade equivalente a $24 \mathrm{Mg} \mathrm{ha}^{-1}$, seu valor com a aplicação de quantidade equivalente a $96 \mathrm{Mg} \mathrm{ha}^{-1}$ de biossólido. A variação no índice de diversidade $(\mathrm{H})$ foi de 2,68 para 2,21 com a aplicação de quantidade equivalente a $6 \mathrm{Mg} \mathrm{ha}^{-1}$ de biossólido e se manteve invariável com a aplicação de quantidades equivalentes a 24 e $96 \mathrm{Mg} \mathrm{ha}^{-1}$ de biossólido. O índice dé dominância (D) aumentou até a aplicação de quantidade equivalente a $6 \mathrm{Mg} \mathrm{ha}^{-1}\left(0,192\right.$ - 0,306), na última dose $\left(96 \mathrm{Mg} \mathrm{ha}^{-1}\right)$ o valor de D decresceu para 0,166. A eqüitabilidade aumentou com aplicação de dose quantidade equivalente a $6 \mathrm{Mg} \mathrm{ha}^{-1}$ de biossólido $(0,687-0,739)$. Com a aplicação de quantidade equivalente a $24 \mathrm{Mg} \mathrm{ha}^{-1}$, este valor foi reduzido para 0,723 , aumentando com a aplicação de quantidade equivalente a $96 \mathrm{Mg} \mathrm{ha}^{-1}$ $(0,800)$. Na segunda época de coleta, 60 dias após o plantio de milho, os valores de $S$ e E, aumentaram com a aplicação de quantidade equivalente a 24 $\mathrm{Mg} \mathrm{ha}^{-1}$, decrescendo com a dose mais elevada $\left(96 \mathrm{Mg} \mathrm{ha}^{-1}\right)$. O valor de $\mathrm{H}$ decresceu até a aplicação de quantidade equivalente a $24 \mathrm{Mg} \mathrm{ha}^{-1}$ de biossólido $(0,34-0,29)$, mantendo este último valor com a aplicação da maior dose (96 Mg $\left.\mathrm{ha}^{-1}\right)$. A variação de $\mathrm{D}$ foi de 0,12 para 0,13 , com a aplicação de quantidade equivalente a $6 \mathrm{Mg} \mathrm{ha}^{-1}$ e 0,24 após a aplicação de quantidade equivalente a 24 $\mathrm{Mg} \mathrm{ha}^{-1}$, diminuindo na última dose (96 $\mathrm{Mg} \mathrm{ha}^{-1}$ ) para 0,15 . Os valores no índice de eqüitabilidade foram reduzidos até a aplicação de quantidade equivalente a 


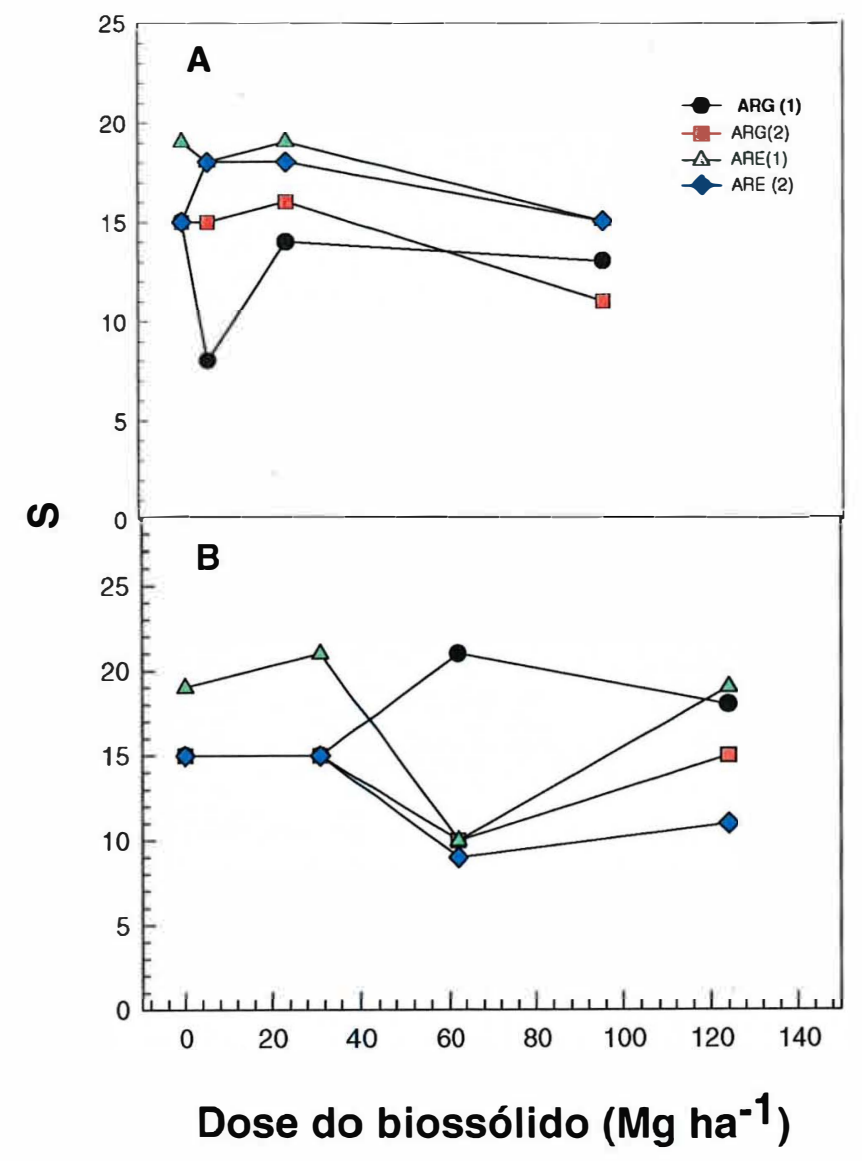

Figura 20 - Índices de diversidade dos amplicons da região V3 do rDNA $16 S$. Riqueza de espécies (S) em solo argiloso (ARG) ou arenoso (ARE), em função da dose de biossólido adicionada, avaliada 30 (1) e 60 (2) dias após o plantio de milho. Os valores de $S$ foram calculados a partir dos dados de abundância relativa dos amplicons. A, solos tratados com biossólido da ETE-Franca: Dose 1, sem adição de biossólido; Dose 2, $6 \mathrm{Mg} \mathrm{ha}^{-1}$; Dose 3, $24 \mathrm{Mg} \mathrm{ha}^{-}$ 1; Dose 4, $96 \mathrm{Mg} \mathrm{ha}^{-1}$; ETE-Barueri: Dose 1, sem adição de biossólido Dose 2, $31 \mathrm{Mg} \mathrm{ha}^{-1}$; Dose 3, $62 \mathrm{Mg} \mathrm{ha}^{-1}$; Dose 4, $124 \mathrm{Mg}$ ha $^{-1}$. A e B, 30 dias após o plantio de milho; $\mathrm{C}$ e D, 60 dias após o plantio de milho. 


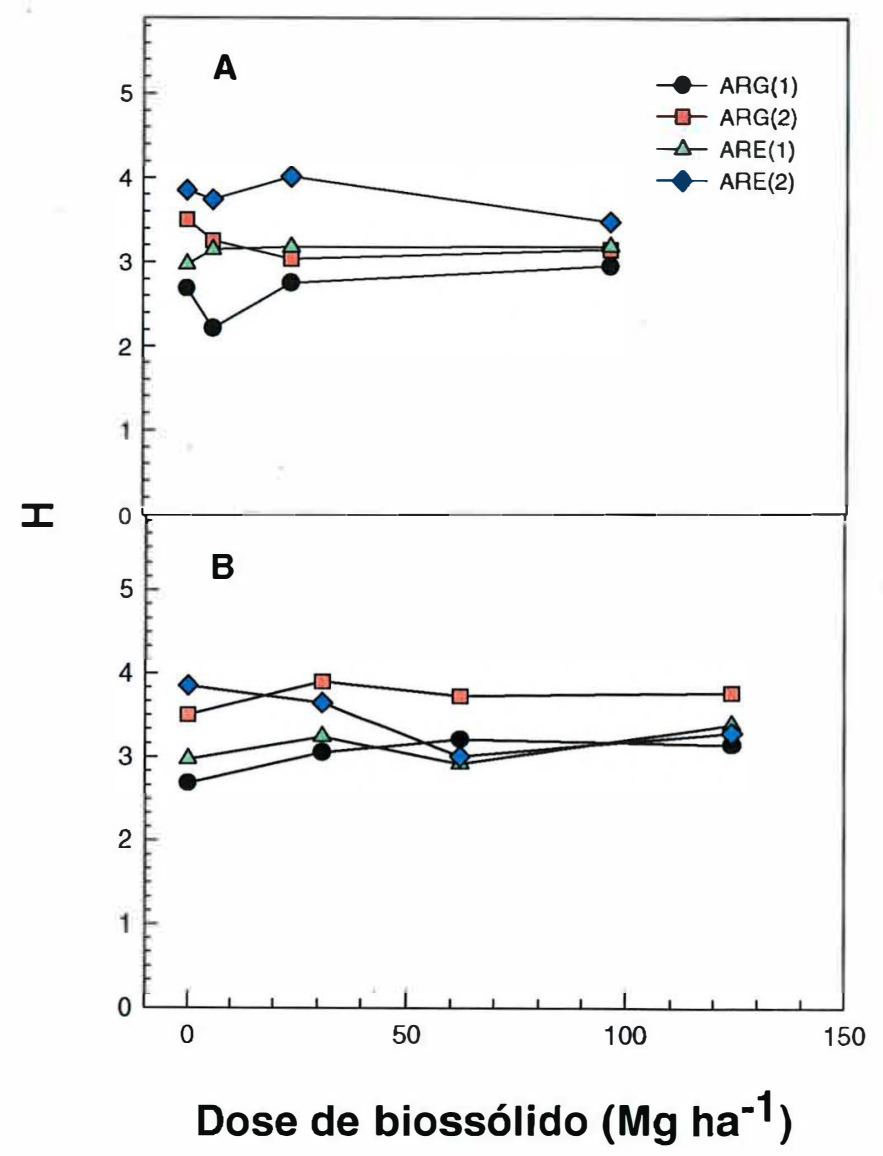

Figura 21 - Índices de diversidade dos amplicons da região V3 do rDNA 165. Índice de Shannon-Weaver $(\mathrm{H})$ em solo argiloso (ARG) ou arenoso (ARE), em função da dose de biossólido adicionada, avaliada 30 (1) e 60 (2) dias após o plantio de milho. Os valores de $S$ foram calculados a partir dos dados de abundância relativa dos amplicons. A, solos tratados com biossólido da ETE-Franca: Dose 1, sem adição de biossólido; Dose 2, $6 \mathrm{Mg} \mathrm{ha}^{-1}$; Dose 3, $24 \mathrm{Mg} \mathrm{ha}^{-}$ 1; Dose 4, $96 \mathrm{Mg} \mathrm{ha}^{-1}$; ETE-Barueri: Dose 1, sem adição de biossólido Dose 2, $31 \mathrm{Mg} \mathrm{ha}^{-1}$; Dose 3, $62 \mathrm{Mg} \mathrm{ha}^{-1}$; Dose 4, $124 \mathrm{Mg}$ ha $^{-1}$. A e B, 30 dias após o plantio de milho; C e D, 60 dias após o plantio de milho. 
$24 \mathrm{Mg} \mathrm{ha}^{-1}(0,89-0,73)$, aumentando posteriormente com a aplicação de quantidade equivalente a $96 \mathrm{Mg} \mathrm{ha}^{-1}$ para 0,88 .

Na primeira época de amostragem (30 dias após o plantio do milho), em solo arenoso, com aplicação do biossólido da ETE-Franca, a comunidade de Bacteria teve a riqueza de espécies variando de 19 (valor do controle) para $18 \mathrm{com}$ aplicação de quantidade equivalente a $6 \mathrm{Mg} \mathrm{ha}^{-1}$. Com a adição de quantidade equivalente a $24 \mathrm{Mg} \mathrm{ha}^{-1}$ novamente obtém-se um $S=19$, reduzido para 15 com a aplicação de $96 \mathrm{Mg} \mathrm{ha}^{-1}$. O H desta comunidade teve um pequeno aumento após a aplicação de quantidade equivalente a $6 \mathrm{Mg} \mathrm{ha}^{-1}$ $(2,97-3,15)$, que se manteve com a aplicação das outras doses. $O$ índice de dominância (D) também sofreu uma pequena redução $(0,16-0,14)$ com a aplicação de quantidade equivalente a $6 \mathrm{Mg} \mathrm{ha}^{-1}$ permanecendo com o mesmo valor com a aplicação de quantidade equivalente a $24 \mathrm{Mg} \mathrm{ha}^{-1}$ e diminuindo para 0,13 , com a aplicação da maior dose $\left(96 \mathrm{Mg} \mathrm{ha}^{-1}\right)$. A eqüitabilidade $(E)$ foi maior à medida que a dose do biossólido aplicado aumentou $(0,70-0,82)$. Na segunda época de coleta, a comunidade de Bacteria de solo arenoso, a variação da riqueza de espécies (S) foi de 15 para 18 após a aplicação de quantidade equivalente a $6 \mathrm{Mg} \mathrm{ha-1}$, não variando com a aplicação de quantidade equivalente a $24 \mathrm{Mg} \mathrm{ha}^{-1}$. Com a aplicação da dose mais alta de biossólido (96 Mg ha-1) o valor de $\mathrm{R}$ foi reduzido para 16.

Quando as amostras foram tratadas com o biossólido da ETEBarueri, em solo argiloso, após 30 do plantio do milho, houve um pequeno aumento na riqueza de espécies quando -o solo foi tratado com quantidade equivalente a $62 \mathrm{Mg} \mathrm{ha}^{-1}$, diminuindo para 18, com a aplicação da dose mais alta do biossólido (124 Mg ha ${ }^{-1}$ ). O H aumentou conforme o aumento da dose de biossólido aplicada, ou seja, 2,8-3,1 para quantidade equivalente a $31 \mathrm{Mg}^{\circ}{ }^{-}$ 1; 3,2 para $62 \mathrm{Mg} \mathrm{ha}^{-1}$, mantendo o mesmo valor após a aplicação de quantidade equivalente a $124 \mathrm{Mg} \mathrm{ha}^{-1}$ de biossólido aplicado. $\mathrm{O}$ índice valor da 


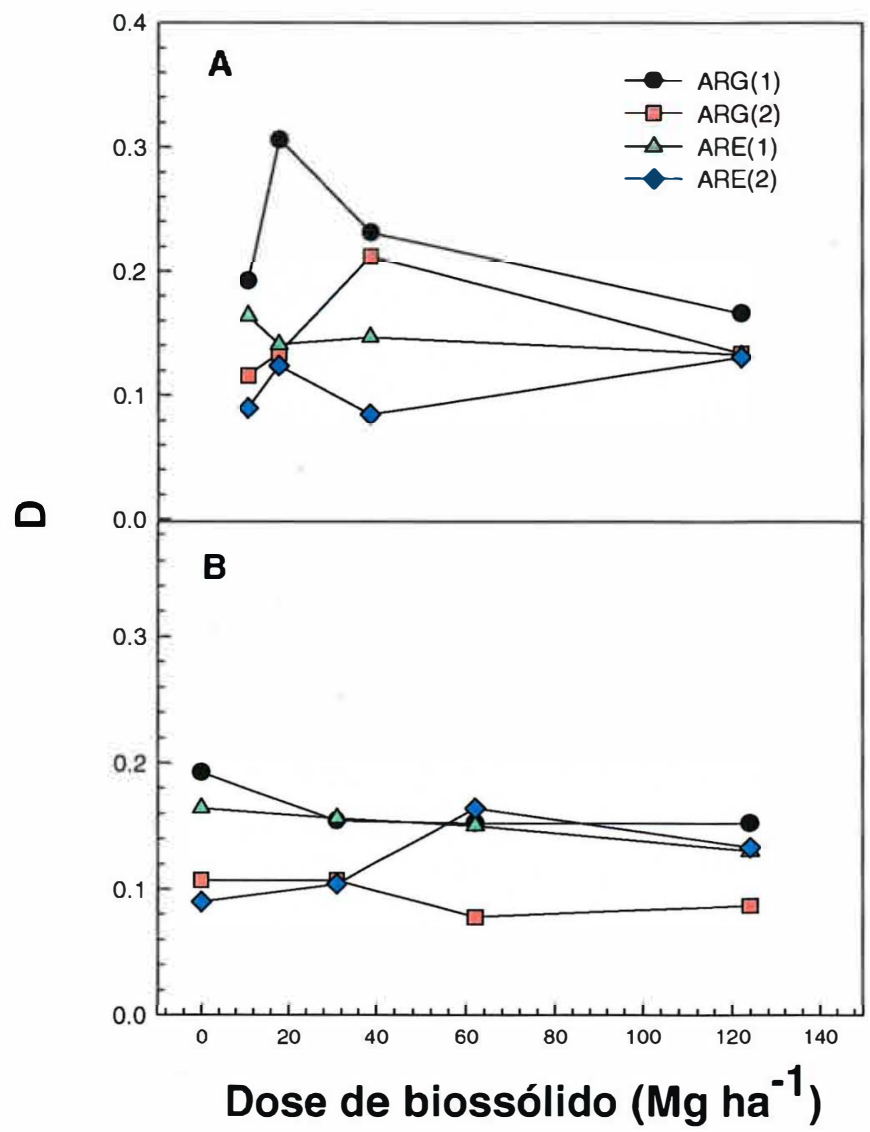

Figura 22 - Índices de diversidade dos amplicons da região V3 do rDNA 165. Índice de dominância de Simpson (D) em solo argiloso (ARG) ou arenoso (ARE), em função da dose de biossólido adicionada, avaliada 30 (1) e 60 (2) dias após o plantio de milho. Os valores de $S$ foram calculados a partir dos dados de abundância relativa dos amplicons. A, solos tratados com biossólido da ETE-Franca: Dose 1, sem adição de biossólido; Dose 2, $6 \mathrm{Mg} \mathrm{ha}^{-1}$; Dose 3, $24 \mathrm{Mg} \mathrm{ha}^{-}$ 1; Dose 4, $96 \mathrm{Mg} \mathrm{ha}^{-1}$; ETE-Barueri: Dose 1, sem adição de biossólido Dose 2, $31 \mathrm{Mg} \mathrm{ha}^{-1}$; Dose 3, $62 \mathrm{Mg} \mathrm{ha}^{-1}$; Dose 4, $124 \mathrm{Mg}$ ha $^{-1}$. A e B, 30 dias após o plantio de milho; C e D, 60 dias após o plantio de milho. 
dominância (D) foi reduzida, com o aumento das doses de biossólido $(0,29$ 0,14). O índice de eqüitabilidade foi sensivelmente reduzido com a aplicação de quantidade equivalente a $62 \mathrm{Mg} \mathrm{ha}^{-1}$, variando de 0,89 para 0,58 , com o aumento da dose para quantidade equivalente a $212,4 \mathrm{~g} \mathrm{~kg}^{-1} \mathrm{o}$ valor de $\mathrm{E}$ retornou a 0,89. Para a segunda amostragem, após 60 dias do plantio de milho, não houve variação nos valores de riqueza de espécies com a aplicação de quantidade equivalente a $31 \mathrm{Mg} \mathrm{ha}^{-1}$ deste biossólido, porém, com a aplicação de quantidade equivalente a $62 \mathrm{Mg} \mathrm{ha}^{-1}$ o valor de $\mathrm{S}$ decresceu para $9 . \mathrm{O}$ valor do índice de diversidade variou 3,3 para 1,9 com a aplicação de quantidade equivalente a $62 \mathrm{Mg} \mathrm{ha}^{-1}$ de biossólido, retornando ao valor inicial com a aplicação de quantidade equivalente a $124 \mathrm{Mg} \mathrm{ha}^{-1}(3,3)$. O S não se altera com o aumento das doses de biossólido. $O$ índice de eqüitabilidade varia de 0,71 para 0,89 após a aplicação de quantidade equivalente a $31 \mathrm{Mg} \mathrm{ha}^{-1}$, diminuindo para $0,72 \mathrm{com}$ a aplicação da segunda dose $\left(62 \mathrm{Mg} \mathrm{ha}^{-1}\right)$, aumentando novamente na dose mais alta $0,78\left(124 \mathrm{Mg} \mathrm{ha}^{-1}\right)$. Estes resultados mostram a ocorrência de variações nos índices de diversidade de Bacteria dessas amostras nas duas épocas de coleta. Em solo arenoso, 30 após o plantio de milho, outro padrão de variação nos índices de diversidade foi observado. A variação da riqueza de espécies foi de 19 para 21 com a aplicação de quantidade equivalente a $31 \mathrm{Mg} \mathrm{ha}^{-1}$ de biossólido, reduzindo para 10 após a aplicação de quantidade equivalente a $62 \mathrm{Mg} \mathrm{ha}^{-1}$, retornando ao valor do controle com o aumento da dose (124 Mg ha-1). $\mathrm{O}$ índice de diversidade variou de 3 para 3,4 com a aplicação de quantidade equivalente a $31 \mathrm{Mg} \mathrm{ha}^{-1}$, repetindo este padrão de variação com a aplicação das doses mais elevadas. $O$ índice de dominância manteve-se com o valor de 0,15 , mesmo com o aumento da dose de biossólido. A eqüitabilidade variou de 0,71 para 76 com a aplicação de quantidade equivalente a $31 \mathrm{Mg} \mathrm{ha}^{-1}$, mantendo este mesmo valor com a aplicação de quantidade equivalente a $62 \mathrm{Mg} \mathrm{ha}^{-1}$, na dose mais alta (124 Mg $\mathrm{ha}^{-1}$ ) o valor de $E$ foi de 0,82 , sugerindo que um maior impacto na comunidade, em relação às doses mais altas de biossólido aplicadas. 


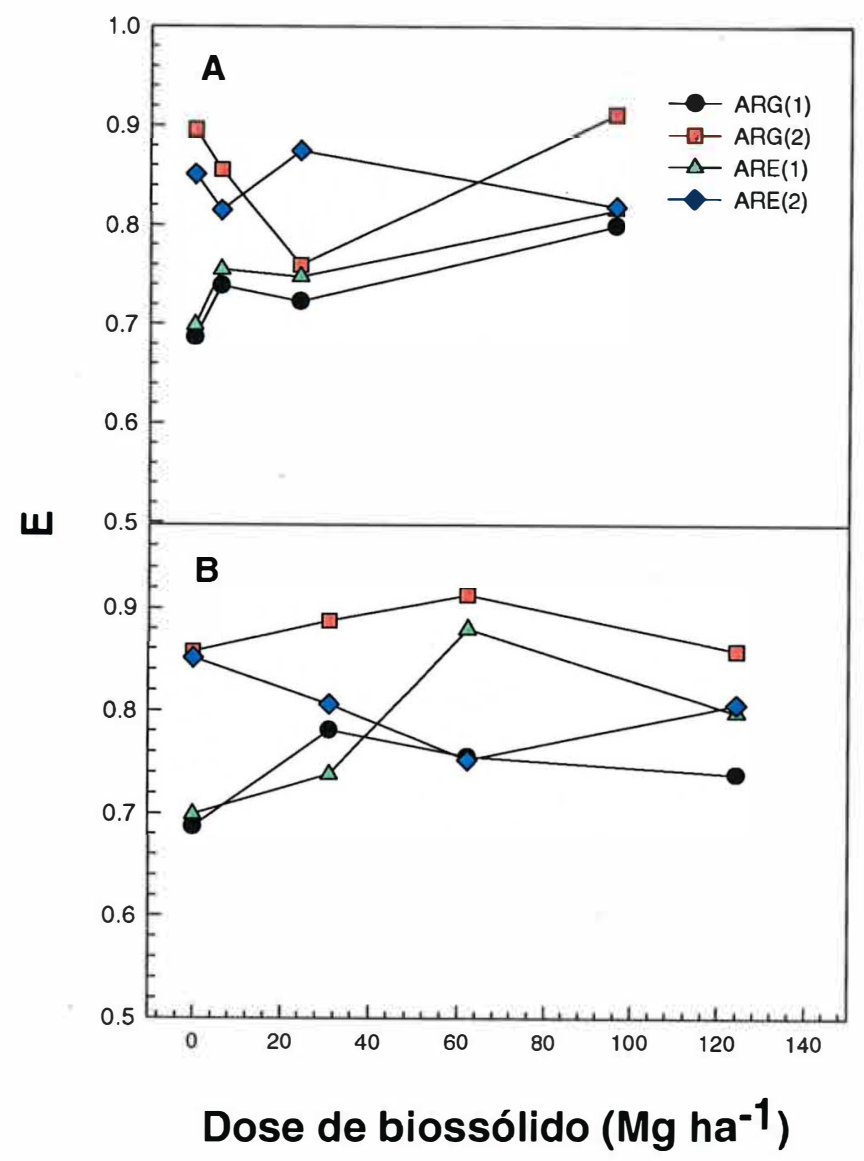

Figura 23 - Índices de diversidade dos amplicons da região V3 do rDNA $16 S$. Índice de eqüitabilidade (E) em solo argiloso (ARG) ou arenoso (ARE), em função da dose de biossólido adicionada, avaliada 30 (1) e 60 (2) dias após o plantio de milho. Os valores de $S$ foram calculados a partir dos dados de abundância relativa dos amplicons. A, solos tratados com biossólido da ETE-Franca: Dose 1, sem adição de biossólido; Dose 2, $6 \mathrm{Mg} \mathrm{ha}^{-1}$; Dose 3, $24 \mathrm{Mg} \mathrm{ha}^{-}$ 1; Dose 4, $96 \mathrm{Mg} \mathrm{ha}^{-1}$; ETE-Barueri: Dose 1, sem adição de biossólido Dose 2, $31 \mathrm{Mg} \mathrm{ha}^{-1}$; Dose 3, $62 \mathrm{Mg} \mathrm{ha}^{-1}$; Dose 4, $124 \mathrm{Mg}$ ha $^{-1}$. A e B, 30 dias após o plantio de milho; C e D, 60 dias após o plantio de milho. 
Os resultados dos índices de diversidade para as amostras coletadas após 60 dias do plantio de milho, em solo arenoso, foram observados variações nos índices, onde a riqueza de espécies reduziu de 15 para 9 com a aplicação de quantidade equivalente a $62 \mathrm{Mg} \mathrm{ha}^{-1}$ de biossólido, aumentando para $11 \mathrm{com}$ a aplicação de quantidade equivalente a $96 \mathrm{Mg} \mathrm{ha}^{-1}$. O índice de diversidade diminuiu somente com a aplicação de quantidade equivalente a $31 \mathrm{Mg} \mathrm{ha}^{-1}$ de biossólido, de 3,3 para 3,1, nas outras doses os valores de $\mathrm{H}$ foram iguais ao controle sem adição de biossólido $(3,3)$. O índice de dominância aumentou de 0,11 para 0,13 , com quantidade equivalente a $31 \mathrm{Mg} \mathrm{ha}^{-1} ; 0,25 \mathrm{com} 62 \mathrm{Mg} \mathrm{ha}^{-1}$ e 0,21 com $124 \mathrm{Mg} \mathrm{ha}^{-1}$ de biossólido aplicado. A eqüitabilidade decresceu de 0,78 para 0,72 após a aplicação de quantidade equivalente a $31 \mathrm{Mg} \mathrm{ha}^{-1}$ de biossólido; reduzindo ainda mais com a aplicação de quantidade equivalente a $62 \mathrm{Mg} \mathrm{ha}^{-1}$ de biossólido $(0,59)$ e finalmente na dose mais alta $\left(124 \mathrm{Mg} \mathrm{ha}^{-1}\right)$, o valor de $E$ teve um aumento em relação ao valor anterior $(0,67)$. A aplicação de biossólido com alto teor de metais pesados em solo, registrou a variação de grande amplitude em todos os índices calculados considerando as duas épocas de coleta. A dominância foi sensivelmente alterada na segunda época de coleta em solo arenoso, mostrando a maior persistência dos efeitos do impacto sobre a comunidade de Bacteria, ou seja, a baixa resiliência do sistema. Devido às características do solo os metais pesados presentes podem estar mais solúveis e contudo mais tóxicos.

As amostras tratadas com biossólido da ETE-Franca a diversidade da comunidade decresceu de 3,6 para 3,2, aumentando posteriormente para 3,7 , e mantendo o mesmo valor com a aplicação de quantidade equivalente a $96 \mathrm{Mg} \mathrm{ha}^{-1}$. A variação da dominância foi de 0,12 para 0,18 após a aplicação de quantidade equivalente a $6 \mathrm{Mg} \mathrm{ha}^{-1}$, decrescendo logo após a aplicação de quantidade equivalente a $24 \mathrm{Mg} \mathrm{ha}^{-1}$ de biossólido. O E decreșceu de 0,78 para 0,75 com a aplicação de quantidade equivalente a $6 \mathrm{Mg} \mathrm{ha}^{-1}$ e aumentou para 
0,77 após a aplicação de quantidade equivalente a $24 \mathrm{Mg} \mathrm{ha}^{-1}$ e 0,83 com a aplicação de quantidade equivalente a $96 \mathrm{Mg} \mathrm{ha}^{-1}$.

Os resultados obtidos em relação aos índices de diversidade sugerem um incremento de espécies provenientes do biossólido. Isso foi observado pelo aumento nos valores de $\mathrm{D}$ e $\mathrm{E}$ e a baixa variabilidade de $\mathrm{H}$, além da redução nos valores de $S$, que expressa a riqueza de espécies. Estes resultados estão relacionados com as doses de biossólido aplicadas, às quais, mostram um efeito acentuado sobre a estrutura da comunidade de Bacteria, como se observa na variabilidade encontrada nos valores de $S$, em relação a dose de biossólido aplicada. Observam-se também, diferenças entre os tratamentos e o controle (solo sem aplicação de biossólido), isso sugere que a aplicação do biossólido resultou em modificações na estrutura da comunidade de Bacteria. As pequenas diferenças entre os índices de diversidade quando comparada a primeira com a segunda amostragem, inclusive em relação aos controles, demonstram alta resiliência do sistema.

Beare et al. (1995) determinaram a capacidade das comunidades microbianas a resistirem aos distúrbios causados pela presença de metais pesados, sugerindo que uma alta resiliência do sistema, pode ser acompanhada do aumento de diversidade. Porém, a elevada diversidade, pode estar associada a atividades microbianas altamente redundantes como forma de resistência (Lambais \& De Souza, 2000).

Walker et al. (1999) estudaram as relações entre a abundância de espécies e resiliência do sistema, concluindo que embora se enfatize a importância da diversidade de espécies para manter uma alta diversidade funcional, a redundância metabólica pode contribuir para manutenção da resiliência em sistemas onde ocorrem mudanças. Após 60 dias a comunidade restabeleceu um estágio de equilíbrio. Porém, não se pode afirmar se a mesma 
estrutura inicial pode ter sido recuperada, para isso seria necessário um estudo mais profundo do sistema. Por outro lado, os resultados obtidos por Niemi et al. (2001), utilizando vários métodos de lise celular para obtenção do DNA e subsequente PCR-DGGE, observaram vários grupos bacterianos dominantes nas amostras de solo. Da mesma forma, Øvreås et al. (1997) observaram um decréscimo na diversidade mas com aumento de algumas populações de bacterias que estavam presentes como populações dominantes.

A comunidade de Bacteria foi avaliada pela análise dos amplicons da região V1-V3 do rDNA 16S, com base nos dados de percentagem relativa, obtidos com o auxílio do programa Fragment Analysis. Foram calculados: a riqueza de espécies ( $\mathrm{R}$; Figura 24), índice de diversidade (H; Figura 25), índice de dominância (S; Figura 26), índice de eqüitabilidade (E; Figura 27). O valor do $R$ das amostras de solo argiloso tratado com biossólido da ETE-Franca, na primeira época de amostragem (30 dias após o plantio de milho), não foi alterado com a aplicação de quantidade equivalente a $6 \mathrm{Mg} \mathrm{ha}^{-1}$ de biossólido (7). Com a aplicação de quantidade equivalente a $24 \mathrm{Mg} \mathrm{ha}^{-1}$ ocorreu uma diminuição (7-3), elevando-se posteriormente para 7 com a aplicação de quantidade equivalente a $96 \mathrm{Mg} \mathrm{ha}^{-1}$. $\mathrm{O}$ valore de $\mathrm{H}$ aumentou muito pouco 2,32,4 , com a aplicação de quantidade equivalente a $6 \mathrm{Mg} \mathrm{ha}^{-1}$ de biossólido, diminuindo posteriormente para 1,8 com a aplicação de quantidade equivalente a $24 \mathrm{Mg} \mathrm{ha}^{-1}$, aumentando para 2,8 na dose mais alta (96 Mg ha-1). O S dessa comunidade de Bacteria, decresceu após a aplicação de quantidade equivalente a $6 \mathrm{Mg} \mathrm{ha}^{-1}$ de biossólido $(0,25-0,22)$, aumentando após a aplicação de quantidade equivalente a $24 \mathrm{Mg} \mathrm{ha}^{-1}$ para 0,29 . Com a aplicação de quantidade equivalente a $96 \mathrm{Mg} \mathrm{ha}^{-1} \mathrm{o}$ valor de $S$ foi de 0,18 . A variação do $E$ foi de 0,81 para 0,80 com a aplicação de quantidade equivalente a $6 \mathrm{Mg} \mathrm{ha}^{-1}$. Com a aplicação de quantidade equivalente a $24 \mathrm{Mg} \mathrm{ha}^{-1}$, o valor de $E$ foi de 0,86 , valor que se manteve na dose mais alta. Na segunda época de coleta (60 dias após o plantio de milho), em solo argiloso, a comunidade de Bacteria teve 


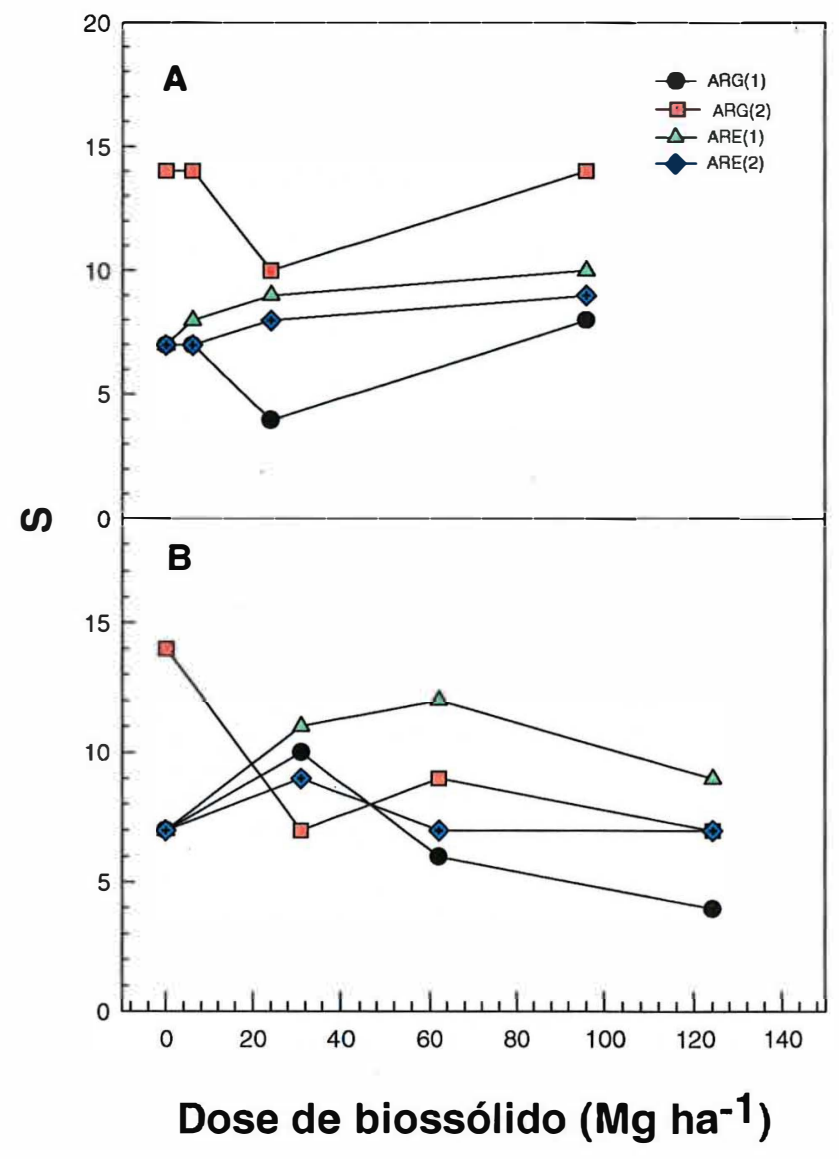

Figura 24 - Índices de diversidade dos amplicons da região V1-V3 do rDNA 16S. Riqueza de espécies (S) em solo argiloso (ARG) ou arenoso (ARE), em função da dose de biossólido adicionada, avaliada 30 (1) e 60 (2) dias após o plantio de milho. Os valores de $S$ foram calculados a partir dos dados de abundância relativa dos amplicons. A, solos tratados com biossólido da ETE-Franca: Dose 1, sem adição de biossólido; Dose 2, $6 \mathrm{Mg} \mathrm{ha}^{-1}$; Dose 3, $24 \mathrm{Mg}$ ha' 1; Dose 4, $96 \mathrm{Mg} \mathrm{ha}^{-1}$; ETE-Barueri: Dose 1, sem adição de biossólido Dose 2, $31 \mathrm{Mg} \mathrm{ha}^{-1}$; Dose 3, $62 \mathrm{Mg} \mathrm{ha}^{-1}$; Dose 4, $124 \mathrm{Mg}$ $h^{-1}$. A e B, 30 dias após o plantio de milho; C e D, 60 dias após o plantio de milho. 


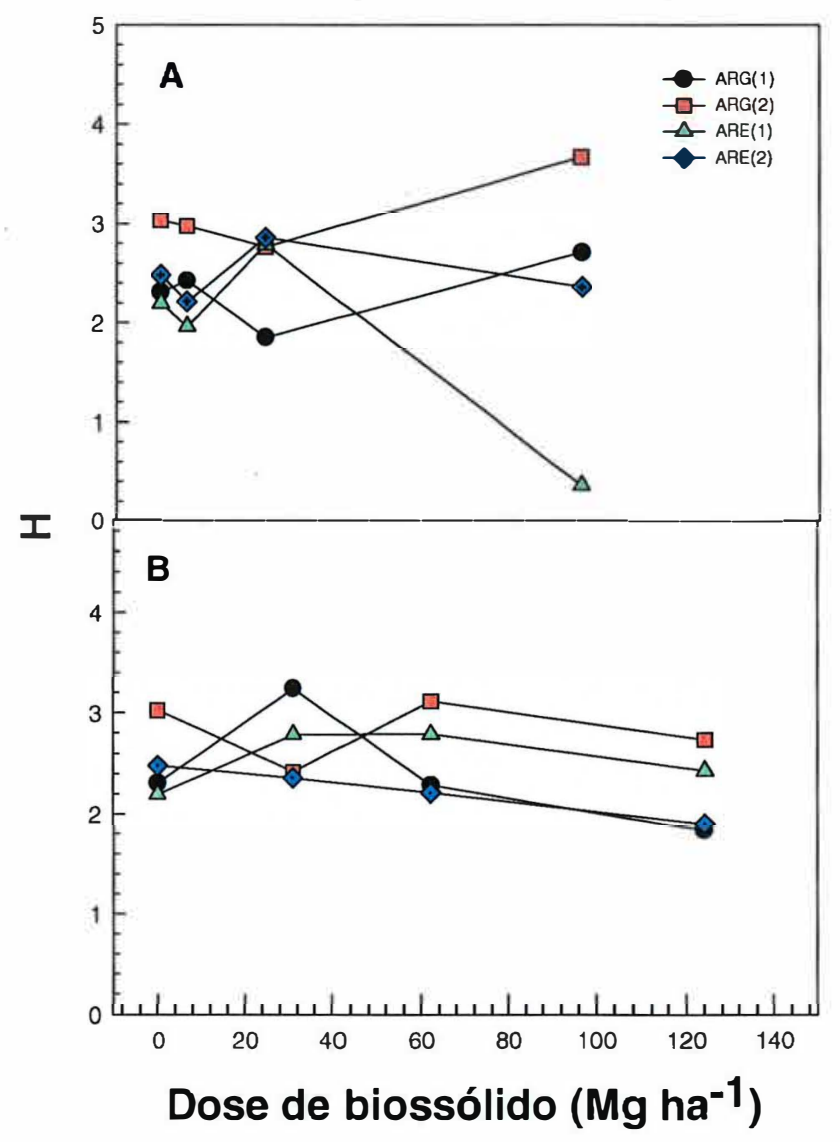

Figura 25 - Índices de diversidade dos amplicons da região V1-V3 do rDNA 16S. Índice de Shannon-Weaver (H) em solo argiloso (ARG) ou arenoso (ARE), em função da dose de biossólido adicionada, avaliada 30 (1) e 60 (2) dias após o plantio de milho. Os valores de $S$ foram calculados a partir dos dados de abundância relativa dos amplicons. A, solos tratados com biossólido da ETE-Franca: Dose 1, sem adição de biossólido; Dose 2, $6 \mathrm{Mg} \mathrm{ha}^{-1}$; Dose 3, $24 \mathrm{Mg} \mathrm{ha}^{-}$ 1; Dose 4, $96 \mathrm{Mg} \mathrm{ha}^{-1}$; ETE-Barueri: Dose 1, sem adição de biossólido Dose 2, $31 \mathrm{Mg} \mathrm{ha}^{-1}$; Dose 3, $62 \mathrm{Mg} \mathrm{ha}^{-1}$; Dose 4, $124 \mathrm{Mg}$ ha $^{-1}$. A e B, 30 dias após o plantio de milho; C e D, 60 dias após o plantio de milho. 
o valor de $\mathrm{R}$ inalterado após a aplicação de quantidade equivalente a $6 \mathrm{Mg} \mathrm{ha}^{-1}$ (14), diminuindo com a aplicação de quantidade equivalente a $24 \mathrm{Mg} \mathrm{ha}^{-1}$ (10), aumentando novamente após a aplicação de quantidade equivalente a $96 \mathrm{Mg}$ $\mathrm{ha}^{-1}$ de biossólido (14). A diversidade $(H)$ diminuiu até a aplicação de quantidade equivalente a $24 \mathrm{Mg} \mathrm{ha}^{-1}(3,0-2,8)$, aumentando com a aplicação de quantidade equivalente a $96 \mathrm{Mg} \mathrm{ha}^{-1}(3,6)$. A dominância (S), diminuiu com a aplicação de quantidade equivalente a $6 \mathrm{Mg} \mathrm{ha}^{-1}(0,20-0,16)$ mantendo este valor após a aplicação de quantidade equivalente a $24 \mathrm{Mg} \mathrm{ha}^{-1}$. $\mathrm{Na}$ dose mais alta (96 Mg ha-1) o valor do índice de dominância foi de 0,095. O E diminuiu com a aplicação de quantidade equivalente a $6 \mathrm{Mg} \mathrm{ha}^{-1}$ de biossólido, aumentando posteriormente até a aplicação de quantidade equivalente a $96 \mathrm{Mg}$ $\mathrm{ha}^{-1}$. Os valores do índice de dominância sofreram as maiores alterações em ambas épocas de coleta.

$\mathrm{Na}$ comunidade de Bacteria do solo arenoso o $\mathrm{R}$ aumentou conforme foi aumentada a dose de biossólido de Franca, aplicado na primeira amostragem. $\mathrm{O} H$ e $\mathrm{E}$ decresceram com a aplicação de quantidades equivalentes a 6 e $96 \mathrm{Mg} \mathrm{ha}^{-1}$ de biossólido. Com a aplicação de quantidade equivalente a $24 \mathrm{Mg} \mathrm{ha}^{-1}$ ocorre um pequeno aumento nestes valores. O S aumenta após aplicação de quantidade equivalente a $6 \mathrm{Mg} \mathrm{ha}^{-1}$ de biossólido e diminui sensivelmente após aplicação de quantidade equivalente a $24 \mathrm{Mg} \mathrm{ha}^{-1}$ sem alteração do valor com a aplicação de quantidade equivalente a $96 \mathrm{Mg}$ ha1. A dominância (S), diminuiu conforme o aumento das doses de biossólidos. Com as pequenas variações detectadas nas análises dos índices de diversidade obtidos a partir dos dados obtidos de amostras amplificadas com os iniciadores BA63fGC e UN518r, não ocorreram alterações na estrutura das comunidades de Bacteria com o tempo de incubação. Em solo argiloso, com o biossólido de Barueri, à comunidade de Bacteria, com aplicação de quantidade equivalente a $31 \mathrm{Mg} \mathrm{ha}^{-1}$ de biossólido, teve os valores de $\mathrm{R}$ e $\mathrm{H}$ aumentados, sendo posteriormente diminuídos até a aplicação de quantidades equivalentes a 
62 e $124 \mathrm{Mg} \mathrm{ha}^{-1}$. O S diminui com a aplicação de quantidade equivalente a 31 $\mathrm{Mg} \mathrm{ha}^{-1}$ de biossólido e aumenta até a aplicação de quantidades equivalentes a 62 e $124 \mathrm{Mg} \mathrm{ha}^{-1}$. O E aumentou com a aplicação de quantidade equivalente a $31 \mathrm{Mg} \mathrm{ha}^{-1}$ de biossólido, mantendo o mesmo valor até a aplicação de quantidades equivalentes a 62 e $124 \mathrm{Mg} \mathrm{ha}^{-1}$. Na segunda época de coleta, o R e o $\mathrm{H}$, diminuíram com a aplicação de quantidades equivalentes a 31 e $124 \mathrm{Mg}$ $\mathrm{ha}^{-1}$ de biossólido. Com a aplicação de quantidade equivalente a $62 \mathrm{Mg} \mathrm{ha}^{-1}$, houve um pequeno aumento. O S não se alterou com a aplicação de quantidades equivalentes a $31 \mathrm{Mg} \mathrm{ha}^{-1}$ e $62 \mathrm{Mg} \mathrm{ha}^{-1}$, sendo menor após a aplicação de quantidade equivalente a $124 \mathrm{Mg} \mathrm{ha}^{-1}$ de biossólido. O S diminuiu e o E se mantiveram com a aplicação de quantidade equivalente a $31 \mathrm{Mg} \mathrm{ha}^{-1}$, aumentando em seguida com a aplicação de quantidade equivalente a $124 \mathrm{Mg}$ $\mathrm{ha}^{-1}$ de biossólido. O E não se alterou com a aplicação de quantidade equivalente a $62 \mathrm{Mg} \mathrm{ha}^{-1}$ mas diminuiu com a aplicação de quantidade equivalente a $124 \mathrm{Mg} \mathrm{ha}^{-1}$ de biossólido. Na segunda coleta, o R aumentou com a aplicação de quantidade equivalente a $31 \mathrm{Mg} \mathrm{ha}^{-1}$, caindo seu valor até a maior dose (124 Mg ha ${ }^{-1}$ de biossólido). O H decresceu, conforme aumentou a dose de biossólido. $O$ valor de $S$ variou de 0,20 para 0,42 , após a aplicação de quantidade equivalente a $31 \mathrm{Mg} \mathrm{ha}^{-1}$, reduzindo em seguida para 0,28 (106,2 $\mathrm{Mg} \mathrm{ha}^{-1}$ ) e finalmente na última dose 0,36 (124 $\mathrm{Mg} \mathrm{ha}^{-1}$ de biossólido). O E diminuiu com a aplicação de quantidades equivalentes a $31 \mathrm{Mg} \mathrm{ha}^{-1}$ e $124 \mathrm{Mg}$ $\mathrm{ha}^{-1}$ de biossólido. A incubação do solo por 60 dias antes do plantio do milho, permitiu que a matéria orgânica adicionada com o biossólido, em altas doses, ainda estivesse disponível, favorecendo o crescimento de espécies microbianas ou induzindo populações do solo, demonstrando uma tendência similar a que foi observada anteriormente, porém, com menor sensibilidade. 


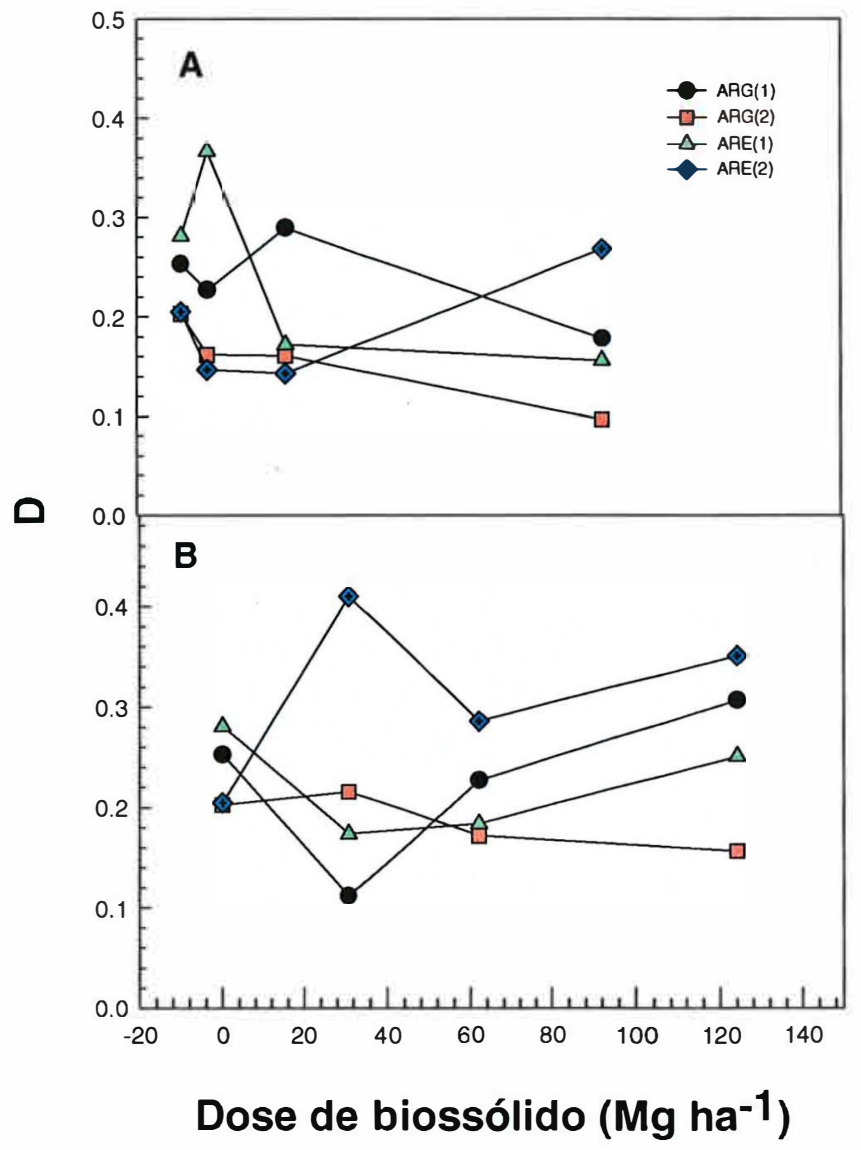

Figura 26 - Índices de diversidade dos amplicons da região V1-V3 do rDNA 16S. Índice de dominância de Simpson (D) em solo argiloso (ARG) ou arenoso (ARE), em função da dose de biossólido adicionada, avaliada 30 (1) e 60 (2) dias após o plantio de milho. Os valores de $S$ foram calculados a partir dos dados de abundância relativa dos amplicons. A, solos tratados com biossólido da ETE-Franca: Dose 1, sem adição de biossólido; Dose 2, $6 \mathrm{Mg} \mathrm{ha}^{-1}$; Dose 3, $24 \mathrm{Mg} \mathrm{ha}^{-}$ 1; Dose 4, $96 \mathrm{Mg} \mathrm{ha}^{-1}$; ETE-Barueri: Dóse 1, sem adição de biossólido Dose 2, $31 \mathrm{Mg} \mathrm{ha}^{-1}$; Dose 3, $62 \mathrm{Mg} \mathrm{ha}^{-1}$; Dose 4, $124 \mathrm{Mg}$ ha $^{-1}$. A e B, 30 dias após o plantio de milho; C e D, 60 dias após o plantio de milho. 


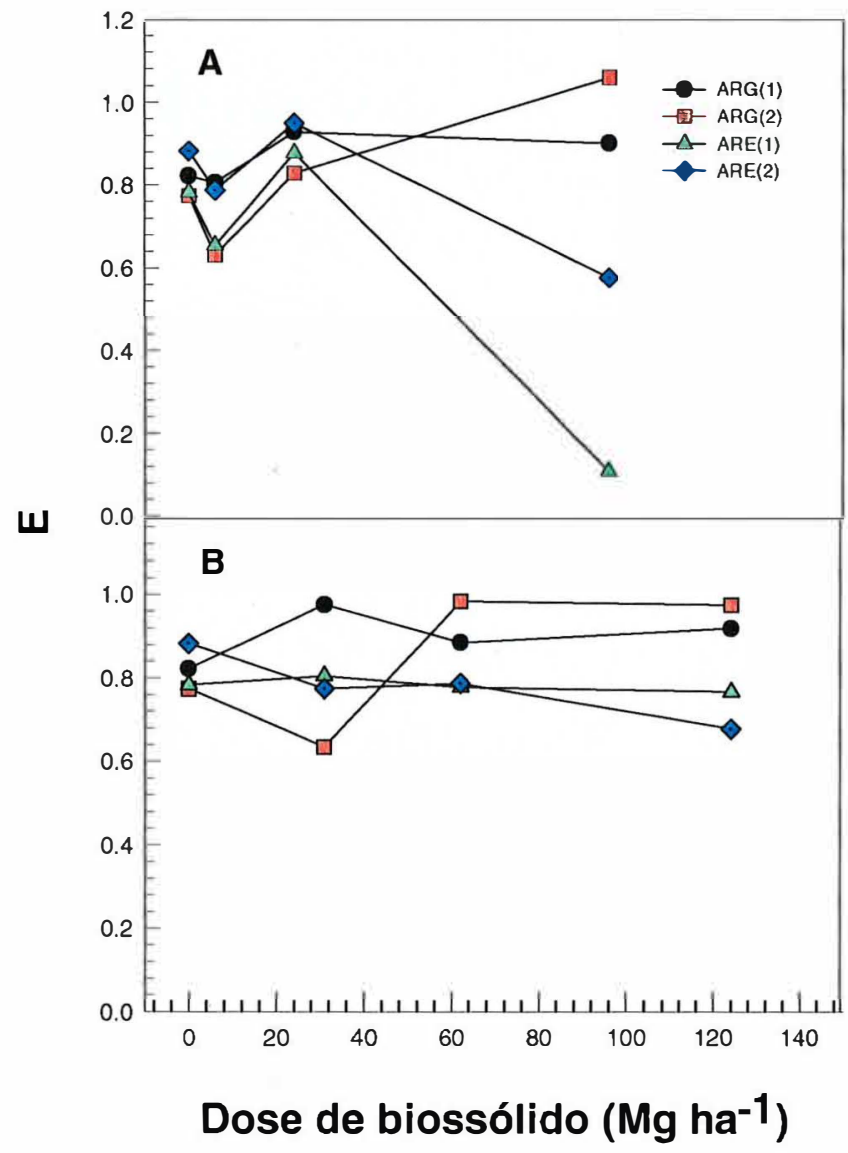

Figura 27 - Índices de diversidade dos amplicons da região V3 do rDNA 165. Índice de eqüitabilidade (E) em solo argiloso (ARG) ou arenoso (ARE), em função da dose de biossólido adicionada, avaliada 30 (1) e 60 (2) dias após o plantio de milho. Os valores de $S$ foram calculados a partir dos dados de abundância relativa dos amplicons. A, solos tratados com biossólido da ETE-Franca: Dose 1, sem adição de biossólido; Dose 2, $6 \mathrm{Mg} \mathrm{ha}^{-1}$; Dose 3, $24 \mathrm{Mg} \mathrm{ha}^{-}$ 1; Dose 4, $96 \mathrm{Mg} \mathrm{ha}^{-1}$; ETE-Barueri: Dose 1, sem adição de biossólido Dose 2, $31 \mathrm{Mg} \mathrm{ha}^{-1}$; Dose 3, $62 \mathrm{Mg} \mathrm{ha}^{-1}$; Dose 4, $124 \mathrm{Mg}$ ha $^{-1}$. A e B, 30 dias após o plantio de milho; C e D, 60 dias após o plantio de milho. 
A associação entre solo e microrganismo é um importante componente do sistema solo-planta-atmosfera e pode ser severamente afetado por fatores abióticos. Quando o sistema atinge o seu maior nível de tamponamento, é necessário um choque muito grande para modificar a estrutura das populações microbianas. Solcs arenosos, com baixo conteúdo de matéria orgânica, não apresentam um sistema ideal à nível de tamponamento. Sendo assim, são mais suscetíveis aos distúrbios, principalmente quando outros fatores estão associados. Ou seja, durante o desenvolvimento do milho, os exsudatos de raízes das plantas podem produzir alterações na constituição de microrganismos. As mudanças observadas na estrutura da comunidade de Bacteria e índices de diversidade foram transientes, provavelmente, devido à baixa concentração de metais pesados e a capacidade do solo em imobilizar estes, minimizando seus efeito. Isso demonstrou a alta resiliência do sistema, devido à versatilidade da comunidade.

As medidas da diversidade têm extensivamente usadas para estimar os efeitos adversos da poluição e distúrbios ambientais, e portanto os efeitos causados por biossólidos com metais pesados. A aplicação de conhecimentos sobre o impacto de atividades antropogênicas na diversidade microbiana pode ajudar não somente a melhorar as práticas de manejo atuais, mas também, pode contribuir para um maior conhecimento sobre a estrutura da comunidade $e$ como esta se relaciona com as práticas de manejo adequadas a um desenvolvimento sustentável.

\subsubsection{Seqüenciamento}

A identificação e caracterização filogenética de microrganismos nãocultiváveis podem ser feitas com a reamplificação dos amplicons recuperados dos géis de DGGE e seqüenciados diretamente ou após a clonagem. A análise das seqüências obtidas para determinação de homologia com outras 
seqüências armazenadas em bancos de dados foi feita através do programa BLAST ("Basic Local Aligment Search Tool - National Center for Biotechnology Information"), pela Internet (http://www.ncbi.nih.gov).

Quatro amplicons foram isolados dos géis (Figura 10 e 12), dos quais, somente o primeiro é que foi clonado. As seqüências referentes aos amplicons 2, 3 e 4, foram obtidas a partir do seqüenciamento direto (Tabela 14). Os amplicons 1 e 2 referem-se aos DNAs isolados do gel de DGGE das amostras coletadas após 30 dias do plantio de milho. Já, os amplicons 3 e 4, foram isolados do gel de DGGE das amostras coletadas após 60 dias do plantio de milho. Os amplicons 1, 2 e 3 foram detectados nas amostras que receberam o biossólido da ETE-Franca, e o amplicon 4, foi detectado em todas as amostras. Estes quatro amplicons foram selecionados para seqënciamento por estarem no gel em maior intensidade, o que permitiu a melhor recuperação do DNA.

Amplicons diferenciais, em solos sob impacto de metais pesados foram observados provavelmente pelas alterações causadas pelo biossólido na estrutura do solo, bem como, a introdução de espécies presentes no biossólido. Estes amplicons foram detectados preferencialmente nas amostras que receberam biossólido da ETE-Franca, indicando que o biossólido da ETEBarueri, provavelmente, foi mais tóxico para comunidade de Bacteria, devido ao seu alto conteúdo de metais pesados. As seqüências de números 1, 2 e 3, estão relacionadas com Streptococcus thermophilus, bactéria não-cultivável TA7, bactéria isolada de solo agrícola, com valores de homologia de 83,88 e $81 \%$, respectivamente. Os amplicons seqüenciados pertencem às amostras de solo arenoso tratado com quantidades equivalentes a 24 e $96 \mathrm{Mg} \mathrm{ha}^{-1}$ do biossólido da ETE-Franca e $62 \mathrm{Mg} \mathrm{ha}^{-1}$ do biossólido da ETE-Barueri. 
Tabela 14. Nível de similaridade das seqüências de nucleotideos dos amplicons da região V3 do rDNA $16 S$ de Bacteria, com seqüências homólogas de vários organismos em bancos de dados, identificados pela comparação das seqüências no programa BLAST

\section{AMPLICON ORGANISMO RELACIONADO SIMILARIDADE VALORE}

\begin{tabular}{|c|c|c|c|}
\hline \multirow[t]{2}{*}{1} & Streptococcus thermophilus & $83 \%$ & $3.10^{-05}$ \\
\hline & seqüência parcial & & \\
\hline \multirow[t]{2}{*}{2} & bacteria não cultivável TA7 & $88 \%$ & $2.10^{-12}$ \\
\hline & seqüência parcial & & \\
\hline \multirow[t]{2}{*}{3} & bactéria isolada de solo agrícola & $81 \%$ & $5.10^{-12}$ \\
\hline & seqüência parcial & & \\
\hline 4 & $\begin{array}{c}\text { Mycobacterium kubicae } 16 S \text { rRNA, } \\
\text { seqüência parcial }\end{array}$ & $92 \%$ & $3.10^{-23}$ \\
\hline
\end{tabular}


O amplicon de número 4, apresentou 92\% de homologia com Mycobacterium. Este gênero é comumente encontrado em solos, juntamente com Agrobacterium, Bacillus, Pseudomonas, Xanthomonas e outros (Tsai et al., 1992). Isso demonstra a potencialidade das técnicas moleculares, que utilizam o DNA ou RNA, como fonte de informação para obter dados sobre aiterações das comunidades em estudos de ecologia.

Grandes proporções de bactérias Gram-positivas podem ser encontradas no solo utilizando substratos disponibilizados pelas plantas. $O$ gênero Streptococcus pode estar presente numa grande variedade de habitats. Solos tratados com biossólidos podem ter alterações devido à presença de organismos, especialmente patógenos, nestes resíduos. A permanência destes organismos introduzidos no solo dependerá da sua capacidade de competição com os antagonistas. Picard et al. (2000) analisaram a biodiversidade de bactérias produtoras de um promotor de crescimento presente na rizosfera de milho durante seus estágios de desenvolvimento. Os resultados obtidos mostram que uma alta variância molecular foi observada com a técnica de RAPD, demonstrando a diversidade genética nesta população e sua função com o estágio de desenvolvimento da planta. Contudo, as bactérias produtoras de 2,4-diacetilfloroglucinol estão presentes em todos os estágios de desenvolvimento do milho em densidades variadas. Entre as espécies identificadas, foram formados dois grupos: o primeiro formado por vários gêneros de Pseudomonas e no segundo estão presentes Enterobacter, Klebisiela pneumoniae e Escherichia coli.

As seqüências obtidas, bem como as que foram homólogas a elas, foram alinhadas e um dendograma gerado, pela associação por vizinhança ("Neighbor-joining") , com o auxílio do pacote de programa Phylip, pela Internet (http://rdp.cme.msu.edu/html/phylip). Quando as seqüências foram comparadas 
com o banco de dados os valores de similaridade obtidos foram baixos, mesmo assim, os relacionamentos podem ser vistos na Figura 28.

clone RF16

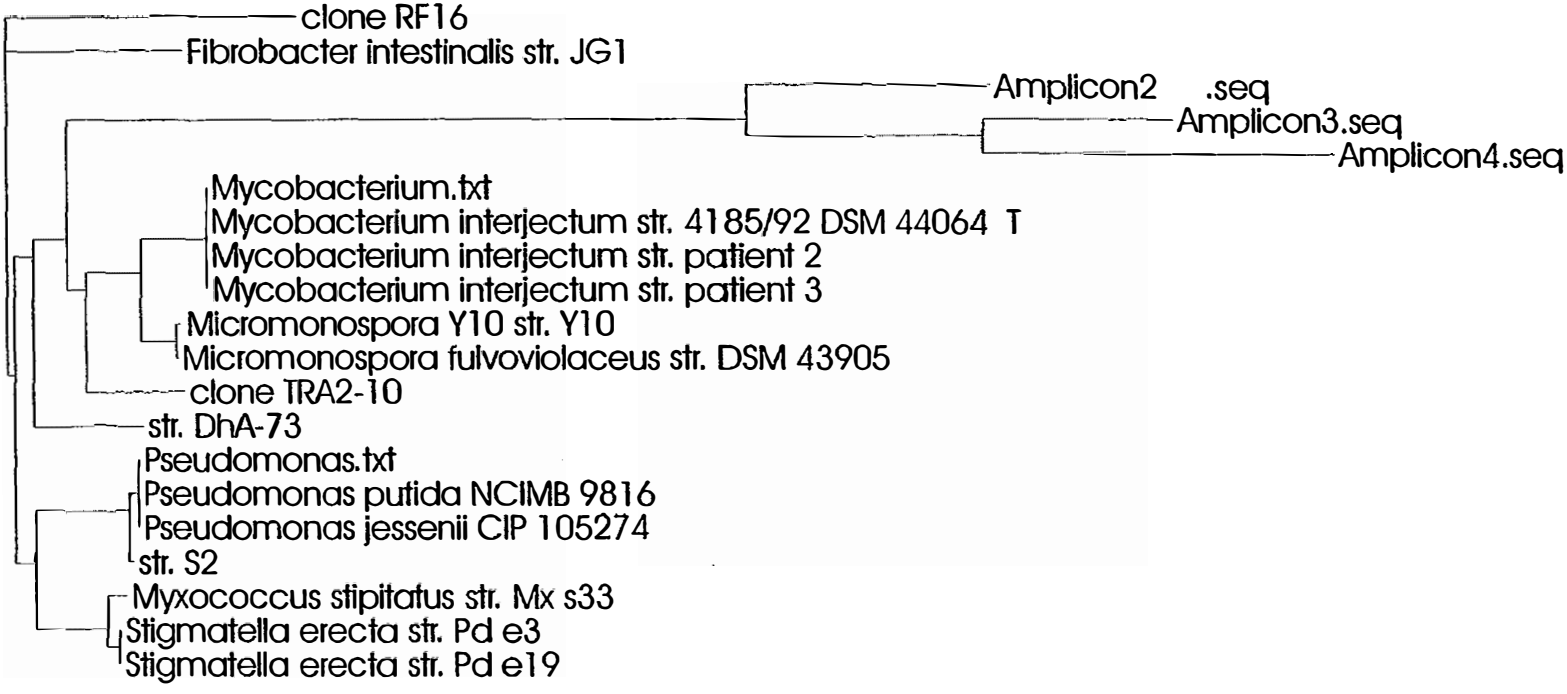

Scale: $\longmapsto-$

Figura 28 - Relações filogenéticas entre os amplicons sequenciados e as seqüências depositadas no GenBank 


\section{CONCLUSÕES}

As análises dos dados e a interpretação dos resultados nesse trabalho permitiram apontar as seguintes conclusões:

- A estrutura de comunidade de Bacteria do solo tratado com biossólido com baixa concentração de metais pesados pode ser alterada temporariamente;

- A estrutura da comunidade de Bacteria foi alterada com a aplicação de biossólidos com altas concentrações de metais pesados, porém os efeitos do distúrbio causado foram minimizados com aumento do tempo de incubação;

- A estrutura da comunidade de Bacteria em solo arenoso foi mais sensível a aplicação de altas concentrações de metais pesados. 


\section{REFERÊNCIAS BIBLIOGRÁFICAS}

ALEXANDER, M. Introduction to soil microbiology. 2.ed. New York: John Wiley, 1977. 467p.

ALTIERI, M.A. The ecological role of biodiversity in agroecosystems. Agriculture Ecosystems \& Environment, v.74, n.1/3, p.19-31, 1999.

AMANN, R. I.; LUDWIG, W.; SCHLEIFER, K.-H. Phylogenetic identification and in situ detection of individual microbial cells without cultivation. Microbiological Reviews, v.59, n.1, p.143-169, 1995.

AMPE, F.; MIAMBI, E. Cluster analysis, richness and biodiversity indexes derived from denaturing gradient gel electrophoresis fingerprints of bacterial communities demonstrate that traditional maize fermentations are driven by the transformation process. International Journal of Food Microbiology, v.60, n.1, p.91-97, 2000.

BÅÅTH, E.; DÍAZ-RAVINA, M.; FROSTEGÅRD, Å. et al. Effect of metal-rich sludge amendments on the soil microbial community. Applied and Environmental Microbiology, v.64, n.1, p.238-245, 1998.

BANERJEE, M.R.; BURTON, D.L.; DEPOE, S. Impact of sewage sludge application on soil biological characteristics. Agriculture, Ecosystems and Environment, v.66, n.3, p.241-249, 1997. 
BAUDOIN, E.; BENIZRI, E.; GUCKERT, A. Metabolic fingerprint of microbial communities from distinct maize rhizosphere compartments. European Journal of Soil Biology, v.37, n.2, p.85-93, 2001.

BEARE, M.H.; COLEMAN, D.C.; CROSSLET, D.A. et al. A hierarchical approach to evaluating the significance of soil biodiversity to biogeochemical cycling. Plant and Soil, v.170, n.1, p.5-22, 1995.

BERTON, R.S.; CAMARGO, O.A.; VALADARES, J.M.A.S. Absorção de nutrientes pelo milho em resposta à adição de lodo de esgoto a cinco solos paulistas. Revista Brasileira de Ciência do Solo, v.13, n.2, p.187-192, 1989.

BENDING, G.D.; PUTLAND, C.; RAYNS, F. Changes in microbial community metabolism and labile organic matter fractions as early indicators of the impact of management on soil biological quality. Biology and Fertility of Soils, v.31, n.1, p.78-84, 2000.

BERGS, C.G.; LINDNER, K.H. Sewage sludge use in the Federal Republic of Germany. European Water Pollution Control, v.7, n.2, p.47-52, 1997.

BORNEMAN, J.; SKROCH, P.W.; O'SULLIVAN, K.M. et al. Molecular microbial diversity of an agricultural soil in Wisconsin. Applied and Environmental Microbiology, v.62, n.6, p.1935-1943, 1996.

BRIM, H.; HEURER, H.; KRÖGERRECKLENFORT, E. et al. Characterization of the bacterial community of a zinc-polluet soil. Canadian Journal of Microbiology, v.45, n.4, p.326-338, 1999.

BROOKES, P.C. The use of microbial parameters in monitoring soil pollution by heavy metals. Biology and Fertility of Soils, v.19, n.4, p.269-279, 1995.

CAMARGO, O.A.; MONIZ, A.C.; JORGE, J.A. et al. Métodos de análise química, mineralógica e física doS solos do Instituto Agronômico de Campinas. Campinas: IAC, 1986. 94p.

CARMO, J.B. Impacto da aplicação de biossólidos nas atividades microbianas do solo. Piracicaba, 2000. 105p. Dissertação (Mestrado). Escola Superior de Agricultura "Luiz de Queiroz", Universidade de São Paulo. 
CHANDER, K.; BROOKES, P.C. Effects of heavy metals from past applications of sewage sludge on microbial biomass and organic matter accumulation in a sandy loam and silt loam u.k. soil. Soil Biology and Biochemistry, v.23, n.10, p.927-932, 1991.

CHANDER, K.; BROOKES, P.C.; HARDING, S.A. Microbial biomass dynamics following addition of metal-enriched sewage sludge to a sandy loam. Soil Biology and Biochemistry, v.27, n.11, p.1409-1421, 1995.

CHANG, A.C.; HYUN, H.N.A.M.; PAGE, A.L. Cadmium uptake for swiss chard grown on composted sewage sludge tredted field plots: plateau or time bomb ? Journal of Environmental Quality, v.26, n.1, p.11-19, 1997.

CHANEY, R.L. Trace metal movement: soil-plant sistems and bioavailability of biosolids-applied metals. In: CLAPP, C.E.; LARSON, W.E; DOWDY, R.H. Sewage sludge: land utilization and the environment. Madison: American Society of Agronomy, 1994. cap. 5, p. 27-31.

CHAPIN III, F:S.; ZAVALETA, E.S.; EVINER, V.T. et al. Consequences of changing biodiversity. Nature, v.405, n.6783, p.234-242, 2000.

DAHLIN, S.; WITTER, E.; MÅRTENSSON, A. et al. Where's the limit ? Changes in the microbiological proprieties of agricultural soils at low levels of metal contamination. Soil Biology and Biochemistry, v.29, n.9/10, p.1405-1415, 1997.

DALMASTRI, C.; CHIARINI, L.; CANTALE, C. et al. Soil type and maize cultivar affect the genetic diversity of maize root-associated Burkholderia cepacia populations. Microbial Ecology, v.38, n.3, p.273-284, 1999.

DUINEVELD, B.M.; KOWALCHUK, G.A.; KEIJZER, A. et al. Analysis of bacterial communities in the rhizosphere of chrysanthemum via denaturing gradient gel electrophoresis of PCR-amplified 16S rRNA as well as DNA fragments coding for $16 \mathrm{~S}$ rRNA. Applied and Environmental Microbiology, v.67, n.1, p.172-178, 2001. 
EATON, A.D.; CLESCERI, L.S.; GRENNBERG, A.E. Standard methods for the examination of water and waste water. 19.ed. Washington: APHA, AWWA, WEF, 1995. 1082p.

EICHNER, C.A.; ERB, R.W.; TIMMIS, K.N. et al. Thermal gradient gel electrophoresis analysis of bioprotection from pollutant shocks in the activated sludge microbial community. Applied and Environmental Microbiology, v.65, n.1, p.102-109, 1999.

EMPRESA BRASILEIRA DE PESQUISA AGROPECUÁRIA. Centro Nacional de Pesquisas de Solos. Sistema brasileiro de classificação de solos. Brasilia, 1999. 412p.

FANTROUSSI, S.E.; VERSCHUERE, L.; VERSTRAETE, W. et al. Effect of phenylurea herbicides on soil microbial communities estimated by analysis of $16 S$ rDNA gene fingerprints and community-level physiological profiles. Applied and Environmental Microbiology, v.65, n.3, p.982-988, 1999.

FERNANDES, F.; PIERRO, A.C.; YAMAMOTO, R.Y. Produção de fertilizantes por compostagem do lodo de esgoto gerado por estações de tratamento de esgotos. Pesquisa Agropecuária Brasileira, v.28, n.5, p.567-574, 1993.

FERNANDEZ, A.; HUANG, S.; SESTON, S. et al. How stable is stable ? Function versus community composition. Applied and Environmental Microbiology, v.65, n.8, p.3697-3704, 1999.

FILSER, J.; FROMM, H.; NAGEL, R.F. et al. Effects of previous intensives agricultural management on microrganisms and the biodiversity of soil fauna. Plant and Soil, v.170, n.1, p.123-129, 1995.

FLIEßBACH, A.; MARTENS, R.; REBER, H.H. Soil microbial biomass ans microbial activity in soils treated with heavy metal contaminated sewage sludge. Soil Biology and Biochemistry, v.26, n.9, p.1201-1205, 1994.

FOGEL, G.B.; COLLINS, C.R.; LI, J. et al. Prokariotic genome siza and SSU rDNA copy number: estimation of microbial relative abundance from a mixed population. Microbial Ecology, v.38, n.2 , p.93-113, 1999. 
FROSTEGÅRD, Å.; TUNID, A.; BÅÅTH, E. Phospholipid fatty acid composition, biomass and activity of microbial communities from soil types experimentally exposed to diferent heavy metals. Applied and Environmental Microbiology, v.59, n.11, p.3605-3617, 1993b.

GELSOMINO, A.; KEIJZER-WOLTERS, A.C.; CACCO, G. et al. Assessment of bacterial community structure in soil polymerase chain reaction and denaturing gel electrophoresis. Journal of Microbiological Methods, v.38, n.1/2, p.1-15, 1999.

GILLER, P.S. Community structure and niche. London: Chapman and Hall, 1984. 176p.

GILLER, K.E.; WITTER, E.; McGRATH. S.P. Toxicity of heavy metal to microorganisms and microbial processes in agricultural soils: a review. Soil Biology and Biochemistry, v.30, n.10/11, p.1389-1414, 1998.

GRIFFITHS, B.S.; BONKOWSKI, M.; ROY, J. et al. Funcionaol stability, substrate utilisation and biological indicators of soils following environmental impacts. Applied Soil Ecology, v.16, n.1, p.49-61, 2001.

GONÇALVES, R.F.; LUDUVICE, M. Experiência da Companhia de Saneamento do Distrito Federal na reciclagem agrícola de biossólido. In: BERTIOL, W.; CAMARGO, O.A. (Ed.) Impacto ambiental do uso agrícola do lodo de esgoto. São Paulo: EMBRAPA/Meio Ambiente, 2000. cap.2, p.153-162.

HALL, J. Standardising and the management of biosolids the international experience In: SEMINÁRIO SOBRE GERENCIAMENTO DE BIOSSÓLIDOS DO MERCOSUL, 1., Curitiba, 1998. Anais. Curitiba: SANEPAR; ABEAS, 1998. p.113-122.

HEURER, H.; SMALLA, K. Aplication of denaturing gradient gel eletrophoresis and temperature gradient gel eletrophoresis for studying soil microbial communities. In: ELSAS, J.D. VAN; TREVORS, J.T. (Ed.) Modern soil microbiology. New York: Marcel Dekker, 1997. cap. 12b, p.353-373. 
IBEKWE, A.M.; PAPIERNIK, S.K.; GAN, J.; et al. Impact of fumigants on soil microbial communities. Applied and Environmental Microbiology, v.67, n.7, p.3245-3257, 2001.

IMHOFF, K.E.; IMHOFF K.R. Manual de tratamento de águas residuárias. São Paulo: Edgard Blücher, 1985. 304p.

JØRGENSEN, S.E. Integration of ecosystem theories: a pattern. Dordrecht: Kluver Academic, 1992. 380p.

KANDELER, E.; KAMPICHLER, C.; HORAK, O. Influence of heavy metals on the functional diversity of soil microbial communities. Biology and Fertility of Soil, v.23, n.3, p. 299-306, 1996.

KENNEDY, A.C. Bacterial diversity in agroecosystems. Agriculture, Ecosystems and Environment, v.74, n.1/3, p.65-76, 1999.

KENNEDY, A.C.; GEWIN, V.L. Soil microbial diversity: present and future considerations. Soil Science, v.162, n.9, p.607-617, 1997.

KENNEDY, A.C.; SMITH, K.L. Soil microbial diversity and the sustentability of agricultural soils. Plant and Soil, v.170, n.1, p.75-86, 1995.

KHAN, M.; SCULLION, J. Effect of soil on microbial responses to metal contamination. Environmental Pollution, v.110, n.1, p.115-125, 2000.

KILLHAM, K. Soil Ecology. New York: Cambridge University Press, 1994. 242p.

KONOPKA, A; ZAKHAROVA, T.; BISCHOFF, M. et al. Microbial biomass and activity in lead-contaminated soil. Applied and Environmental Microbiology, v. 65, n.5, p.2256-2259, 1999b.

KOSTOV, O.; CLEEMPUT, O. van Nitrogen transformations in coppercontaminated soils and effects of lime and compost applications on soil resiliency. Biology and Fertility of Soils, v.33, n.1, p.10-16, 2001.

KOWALCHUK, G.A; STEPHEN, J.R.; DE BOER, W. et al. Analysis of ammoniaoxidizing bacteria of the beta subdivision of the class Proteobacteria in coastal sand dunes by denaturing gradient gel electrophoresis and 
sequencing of PCR-amplified 165 ribosomal DNA fragments. Applied and Environmental Microbiology, v.63, n.4, p.1489-1497, 1997.

KOWALCHUK, G.A.; NAOUMENKO, Z.S.; DERIKX, P.J.L. et al. Molecular analysis of ammonia-oxidizing Bacteria of the $\beta$ subdivision of the class Proteobacteria in compost and composted materials. Applied and Environmental Microbiology, v.65, n.2, p.396-403, 1999.

KOZDRÓJ, J.; ELSAS, J.D. van. Application of polymerase chain reactiondenaturins gradient gel electrophoresis for comparison of direct and indirect extraction methods of soil DNA used for microbial community fingerprinting. Biology and Fertility of Soils, v.31, n.5, p.372-378, 2000.

KOZDRÓJ, J.; ELSAS, J.D. van. Structural diversity of microbial communities in arabe soils of a heavily industrialised area determined by PCR-DGGE fingerprinting and FAME profiling. Applied Soil Ecology, v.17, n.1, p.31-42, 2001.

KUPERMAN, R.G.; CARREIRO, M.M. Soil heavy metal concentrations, microbial biomass and enzyme activities in a contaminated grassland ecosystem. Soil Biology and Biochemistry, v.29, n.2, p.179-190, 1997.

KUSKE, C.R.; BARNS, S.M.; BUSCH, J.D. Diverse uncultivated bacterial groups from soils of the arid Southwestern United States that are present in many geographic regions. Applied and Environmental Microbiology, v.63, n.10, p.3614-3621, 1997.

KUNITO, T.; SAEKI, K.; OYAIZU, H. et al. Influences of copper forms on the toxicity to microorganisms in soils. Environmental and Environmental Safety, v.44, n.2, p.174-178, 1999.

KREBS, C.J. Ecological metodology. New York: Herper Collins, 1989. 654p. LAMBAIS, M.R.; De SOUZA, A.G. Impacto de biossólidos nas comunidades microbianas dos solos. In: BERTIOL, W.; CAMARGO, O.A. (Ed.) Impacto ambiental do uso agrícola do lodo de esgoto. São Paulo: EMBRAPAMeio Ambiente, 2000. cap.3, p.269-279. 
LEITA, L.; De NOBILI, M.; MUHLBACHOVA, G. et al. Bioavailability and effects of heavy metals on soil microbial biomass survival during laboratory incubation. Biology and Fertility of Soil, v.19, n.2/3, p.103-108, 1995.

LIESACK, W.; JANSSEN, P.H.; RAYNEY, F.A. et al. Microbial diversity in soil: the need for a combinated approach using molecular and cultivation techniques. In: ELSAS, J.D. VAN, TREVORS, J.T. Modern soil microbiology. New York: Marcel Dekker, 1997. cap. 14, p.375-385.

LOGAN, T.J.; LINDSAY, B.J.; GOINS, L. EL. et al. Field assessment of sludge metal bioavailability to crops: sludge rate response. Journal of Environmental Quality, v.26, n.2, p.534-550, 1997.

MACNAUGHTON, S.; STEPHEN, J.R.; CHANG, Y-J. et al. Characterization of metal-resistant soil eubacteria by polimerase chain reaction - denaturing gradient gel electrophoresis with isolation of resistant strains. Canadian Journal of Microbiology, v.45, n.2, p.116-124, 1999.

MATTIAZZO-PREZOTTO, M.E. Comportamento de $\mathrm{Cu}, \mathrm{Cd}, \mathrm{Cr}, \mathrm{Ni}, \mathrm{Zn}$ adicionados à solos de clima tropical em diferentes valores de $\mathrm{pH}$. Piracicaba, 1994. 197p. Tese (Livre-Docência) - Escola Superior de Agricultura "Luiz de Queiroz", Universidade de São Paulo.

McCANN, K.S. The diversity - stability debate. Nature, v.405, n.6783, p.228233, 2000.

McGRATH, S.P. Effects of heavy metals from sewage sludge on soil microbes in agricultural ecosystems. In: ROSS, S.M. Toxic metals in soil-plant systems. New York: John Wiley, 1994. cap.2, p.247-274

McGRATH, S.P.; CHAUDRI, A.M.; GILLER, K.E. Long-term effects of land application of sewage sludge: soils, microorganisms and plants. Journal of Industrial Microbiology, v.14, n.2, p.94-104, 1995.

MIETHLING, R.; WIELAND, G.; BACKHAUS, H. et al. Variation of microbial rhizosphere communities in response to crop species, soil origin, and inoculation with Sinorhizobium meliloti L33. Microbial Ecology, v.40, n.1, p.43-56, 2000. 
MUYZER, G.; DE WAAL, E.C.; UITTERLINDEN, A.G. Profiling of complexe microbial populations by denaturing gradient gel electrophoresis analysis of polymerase chain reaction-amplified genes coding for 165 rRNA. Applied and Environmental Microbiology, v.59, n.3, p.695-700, 1993.

MYERS, R.M.; MANIATIS, T.; LERMAN, L.S. Detection and localization of single base changes by denaturing gradient gel electrophoresis. Methods in Enzymology, v.155, p.501-527, 1987.

NARDIN, G.; CHABRIER, J.P. France: eastern France - Franche Compte region, city of Besançon. In: MATTHEWS, P. (Ed.) A global atlas of wastewater sludge and biossolids use and disposal. London: IAWQ, 1997. p.65-69.

NIEMI, R.M.; HEISKANEN, I.; WALLENIUS, K. et al. Extraction and purification of DNA in rhizosphere soil samples for PCR-DGGE analysis of bacterial consortia. Journal of Microbiological Methods, v.45, n.3,p.155-165, 2001. NÜBEL, U.; GARCIA-PICHEL, F.; KÜHL, M. et al. Quantification micriial diversity: morphotypes, 16S rRNA genes, and carotenoids of oxygenic phototrophs in microbial mats. Applied and Environmental Microbiology, v.65, n.2, p.422-430, 1999.

OBBARD, J.P. Ecotoxicological assessment of heavy metals in sewage sludge amended soils. Applied Geochemistry, v.16. n.11/12, p.1405-1411, 2001.

OLIVEIRA, F.C. Metais pesados e formas nitrogenadas em solos tratados com lodo de esgoto. Piracicaba, 1995. 90p. Dissertação (Mestrado) - Escola Superior de Agricultura "Luiz de Queiroz", Universidade de São Paulo.

ØVREÅS, L.; TORSVIK, V. Microbial diversity and community structure in two different agricultural soil communities. Microbial Ecology, v.36, n.3, p.303315, 1998.

ØVREÅS, L.; FORNEY, L.; DAAE, F.L. et al. Distribution of bacterioplankton in Meromictic Lake Sælennannet, as determined by denaturing gradient gel electrophoresis of PCR-amplified gene fragments coding for 16S rRNA. Applied and Environmental Microbiology, v.63, n.9, p.3367-3373, 1997. 
PANNANEN, T.; FROSTEGÅRD, Å.; FRITZE, H. et al. Phospholipid fatty acid composition and heavy metal tolerance of soil microbial communities along two heavy metal-polluted gradients in coniferous forest. Applied and Environmental Microbiology, v.62, n.2, p.420-428, 1996.

PAUL, E.A.; CLARCK, F.E. Soil microbiology and biochemistry. San Diego: Academic Press, 1996. 436p.

PICARD, C.; CELLO, F.DI; VENTURA,M. et al. Frequency and biodiversity of 2,4-diacetylphloroglucinol-producing bacteria isolated from the maize rizhosphere at different stages of plant growth. Applied and Environmental Microbiology, v.66, n.3, p.948-955, 2000.

PROJETO Tietê. Revista de Engenharia, n.527, p.82-90, 1998.

PRIHA, O.; GRAYSTON, S.J.; HUIKKA, R. et al. Microbial community structure and characteristics of the organic matter in soils under Pinus sylvestris, Picea abies and Betula pendula at two forest sites. Biology and Fertility of Soil, v.33, n.1, p.17-24, 2001.

QUICKE, D.L.J. Principles and techniques of contemporary taxonomy. London: Chapman \& Hall, 1993. 311p.

RAIJ, B. van; CANTARELLA, H.; QUAGGIO, J.A. et al. Recomendações de adubação e calagem. 2. ed. Campinas: IAC. 1996. 285p. (Boletim Técnico, 100)

RAPPAPORT, B.D.; MARTENS, D.C.; RENEAU JR; R.B. et al. Metal availability in sludge-amended soils with elevated metals levels. Journal of Environmental Quality, v.17, n.1, p.42-47, 1988.

REBER, H.H. Simultaneous estimates of the diversity and the degradative capability of heavy-metal-affected soil bacterial communities. Biology and Fertility of Soil, v.13, n.3, p.181-186, 1992.

ROANE, T.M. Lead resistance in two bacterial isolates from heavy metalcontaminated soils. Microbial Ecology, v.37, n.3, p.218-224, 1999. 
ROCHELLE, P.A; WILL, J.A.K.; FRY, J.C. et al. Extraction and amplification of 16S rDNA genes from deep marine sediments and sewawater to asses bacterial community diversity. In: ELSAS, J.D. van; TREVORS, J.T. Nucleic acids in the environment: methods and applications. Berlin: SpringerVerlag, 1995. cap. 11, p.219-239.

ROSADO, A.S.; DUARTE, G.F.; SELDIN, L. et al. Molecular microbial ecology: a minireview. Revista de Microbiologia, v.28, n.3, p.135-147, 1997.

ROSS, S.M. Sources and forms of potentially toxic metals in soil-plant systems. In: ROSS, S.M. Toxic metals in soil-plant systems. New York: John Wiley, 1994. cap.1, p.3-25.

SAMBROOK, J.; FRITSCH, E.F.; MANIATIS, T. Molecular cloning: a laboratory manual. 2.ed. Cold Spring Harbor: Cold Spring Harbor Laboratory Press, 1989. 3 v.

SANGER, F.; NICKLEN, S.; COULSON, A.R. DNA sequencing with chainterminating inhibitors. Proceedings of the National Academic of Science of the United States of America, v.74, n.12, p.5463-5467, 1977.

SANTOS, H.F.; TSUTYA, M.T. Aproveitamento e disposição final do lodo de estações de tratamento de esgotos. s.l. : s.ed, 1998. 26p. (Relatório Interno).

SANTOS, H.F.; TSUTYA, M.T.; MIKI, M.K. et al. Critérios para o uso agrícola dos biossólidos de ETEs da SABESP. São Paulo: SABESP, 1997. 35p. (Relatório Interno).

SANDAA, R.A.; ENGER, Ø.; TORSVIK, V. Abundance and diversity of Archaea in heavy-metal-contaminated soils. Applied and Environmental Microbiology, v.65, n.8, p.3293-3297, 1999.

SÃO PAULO (ESTADO). Norma Técnica nop4.230. Aplicação de lodos de sistemas de tratamento biológico em áreas agrícolas - critérios para projeto e operação, São Paulo: CETESB, 1999. 
SCHNEEGURT, M.A.; KULPA, C.F. The application of molecular techniques in environmental biotechnology for monitoring microbial systems. Biotechnolgy Applied Biochemistry, v.27, pt.2, p.73-79, 1998.

SCHULER, M.A.; ZIELINSKI, R.E. Methods in plant molecular biology. San Diego: Academic Press, 1989. 171p.

SHEN, D. Microbial diversity and aplication of microbial products for agricultural purposes in China. Agricultural, Ecosystems \& Environment, v.62, n.2/3, p.237-245, 1997.

SILVA, F.C. Uso agronômico de lodo de esgoto: efeitos em fertilidade do solo e qualidade da cana de açúcar. Piracicaba, 1995. 159p. Tese (Doutorado) Escola Superior de Agricultura "Luiz de Queiroz", Universidade de São Paulo.

SITAULA, B.K.; ALMÅS, Å.; BAKKEN, L.R. et al. Assessment of heavy metals associated with bacteria in soil. Soil Biology and Biochemistry, v.31, n.2, p.315-316, 1999.

SMALLA, K.; CRESSWELL, N.; MENDONÇA-HAGLER, L.C. et al. Rapid DNA extraction protocol from soil for polymerase chain reaction-mediated amplification. Journal of Applied Bacteriology, v.74, n.1, p.78-85, 1993.

SMALLA, K.; WACHTENDORF, U.; HEURER, H. et al. Analysis of BIOLOG GN substrate utilization patterns by microbial communities. Applied and Environmental Microbiology, v.64, n.4, p.1220-1225, 1998.

SNEATH, P.H.A.; SOKAL, R.R. Numerical taxonomy. San Francisco: Freeman, 1973. 856p.

SPSS, SYSTAT 8.0 statistcs. Chicago, Illinois, 1998. 1086p.

STEPHEN, J.R; CHANG, Y-J; MACNAUGHTON, S.J. et al. Fate of a metalresistant inoculum in contaminated and pristine soils assessed by denaturing gradient gel electrophoresis. Environmental Toxicology and Chemistry, v.18, n.6, p.1118-1123, 1999. 
SWIEBER, F.; TEBBE, C.C. A new approach to utilize PCR-single-conformation polymorfism for 16S rRNA gene-based microbial community analysis. Applied and Environmental Microbiology, v.64, n.12, p.4870-4876, 1998.

TORSVIK, V.L., DAAE, F.L.; GOKSOYR, J. Extraction, purification, and analysis of DNA from soil bacteria. In: TREVORS, J.T.; ELSAS, J.D. van Nucleic acids in the environment: methods and applications. Berlin: SpringerVerlag, 1995. cap 3, p.29-48.

TORSVIK, V.L.; DAAE, F.L.; SANDAA, R.A. et al. Novel techniques for analyzing microbial diversity in natural and perturbad environments. Journal of Biotechnology, v.64, n.1, p.53-62, 1998.

TREVORS, J.T.; ELSAS, J.D. van Introduction to nucleic acids in the environment: methods and applications. In: TREVORS, J.T.; ELSAS, J.D. van Nucleic acids in the environment: methods and applications. Berlin: Springer-Verlag, 1995. cap 1, p.1-7.

TSAI, S.M.; BARAIBAR, V.L.; ROMANI, V.L.M. Efeitos de fatores físicos e químicos sobre microrganismos do solo: umidade e aeração. In: CARDOSO, E.J.B.N. (Coord.), Microbiologia do solo. Campinas: Sociedade Brasileira de Ciência do. Solo, 1992. 360p.

TSAI, Y.L.; OLSON, B.H. Rapid method for direct extraction of DNA from soil and sediments. Applied and Environmental Microbiology, v.57, n.4, p.1070-1074, 1991.

TSAI, Y.L.; OLSON, B.H. Detection of low number of bacterial cells in soils and sediments by polymerase chain reaction. Applied and Environmental Microbiology, v.58, n.2; p.754-757, 1992.

TSAI, Y.L.; PARK, M.J.; OLSON, B.H. Rapid method for extraction of mRNA from seeded soils. Applied and Environmental Microbiology, v.57, n.3, p.765-768, 1991.

TSUTYA, M.T. Alternativas de disposição final de biossólidos gerados em estações de tratamento de esgotos. In: BERTIOL, W.; CAMARGO, O.A. 
Impacto ambiental do uso agrícola do lodo de esgoto, Jaguariúna: EMBRAPAMeio Ambiente, 2000. cap.1, p.69-105.

UNITED STATES. Environmental Protection Agency. Standarts for the use or disposal of sewage sludge: 40 CFR Prts 403 and 503. Washington, 1995b. 25p.

VORTMANN, H.; WAGNER, R. Agricultura ecológica: teórica e prática. Porto Alegre: Mercado Aberto, 1987. 168p.

WALKER, B.; KINZIG, A.; LANGRIDGE, J. Plant attribute diversity, resilience, and ecosystem function: the nature and significance of dominant and minor species. Ecosystems, v.2, n.2, p.1-6, 1999.

WALTER, J.; TANNOCK, G.W.; TILSALA-TIMISJARVI, A. et al. Detection and identification of gastrointestinal Lactobacillus species by using denaturing gradient gel electrophoresis and species-species PCR primers. Applied and Environmental Microbiology, v.66, n.1, p.297-303, 2000.

WATVE, M.G.; GANGAL, R.M. Problems in measuring bacterial diversity and a possible solution. Applied and Environmental Microbiology, v.62, n.11, p.4299-4301, 1996.

WIDMER, F.; FLIEßBACH, A.; LACZKÓ, E. et al. Assessing soil biological characteristics: a comparison of bulk soil community DNA-, PLFA-, and Biolog $^{\mathrm{TM}}$-analyses. Soils Biology \& Biochemistry, v.33, n.7/8, p.10291036, 2001.

YANG, C.H.; CROWLEY, D.E.; BORNEMAN, J. et al. Microbial phyllosphere populations are more complex than previously realized. Proceedings of the National Academic of Science of the United States of America, v.98, n.7, p.3889-3894, 2001.

YAO; H.; HE, Z.; WILSON, M.J. et al. Microbial biomass and community structure in a sequence of soils with increasing fertility and changing land use. Microbial Ecology, v.40, n.3, p.223-237, 2000. 
ZAK, J.C.; WILLIG, M.R.; MOORHEAD, D.L. et al. Functional diversity of microbial communities: a quantitative approach. Soil Biology and Biochemistry, v.26, n.9, p.1101-1108, 1994.

ZHOU, J.; BRUNS, M.A.; TIEDJE, J.M. DNA recovery from soils of diverse composition. Applied and Environmental Microbiology, v.62, n.2, p.316322, 1996. 